DOE/RL-96-63

Revision 0

UC-630

\title{
Annual Hanford Site Environmental Permitting Status Report
}

S. A. Thompson

Date Published

October 1996

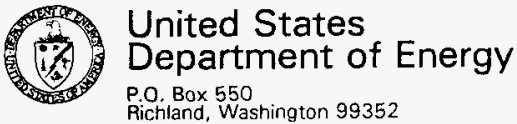

Approved for Public Release 
TENTTONALLY BLANK 


\begin{tabular}{|l}
\hline \multicolumn{2}{|c|}{ A. Information Category } \\
\hline Speech or Presentation \\
$\square$ Full Paper \\
$\square$ Summary \\
$\square$ Journal Article \\
$\square$ Abstract \\
$\square$ Voltimedia Presentation \\
$\square$ Visual Aid \\
$\square$ Other Report \\
\hline
\end{tabular}

D. Document Title

Annual Hanford Site Environmental Permitting Status Report
B. Document ID Number (include rev, vol., etc.)

DOE/RL-96-63. Revision 0

C. List attachments (i.e., copyright permission, copyright transfer)

none

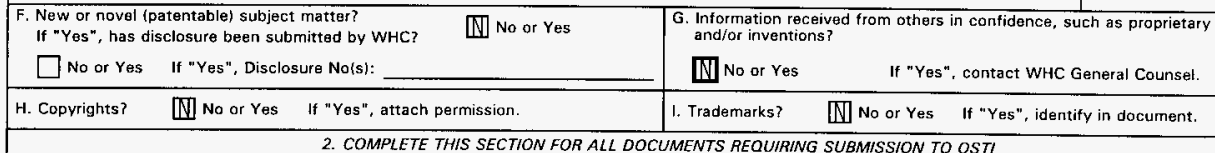

\begin{tabular}{|c|c|c|c|}
\hline A. Unclassified Category & $U C-630$ & $1 C 2000$ & B. Budget \& Reporting Code \\
\hline
\end{tabular}

3. COMPLETE THIS SECTION ONLY FOR A JOURNAL SUBMISSION

A. Title of Journat $N / A$

4. COMPLETE THIS SECTION ONLY FOR A SPEECH OR PRESENTATION

\begin{tabular}{|c|c|c|c|}
\hline \multicolumn{2}{|c|}{$\begin{array}{l}\text { A. Title for Conference or Meeting } \\
\text { N/A }\end{array}$} & $\begin{array}{l}\text { B. Group or Society Sponsoring } \\
\text { N/A }\end{array}$ & \\
\hline $\begin{array}{l}\text { C. Datels) of Conference } \\
\text { or Meeting }\end{array}$ & D. City/State & E. Will material be published in proceedings? & No or Yes \\
\hline$N / A$ & $N / A$ & Will material be handed out? & ] No or Yes \\
\hline
\end{tabular}

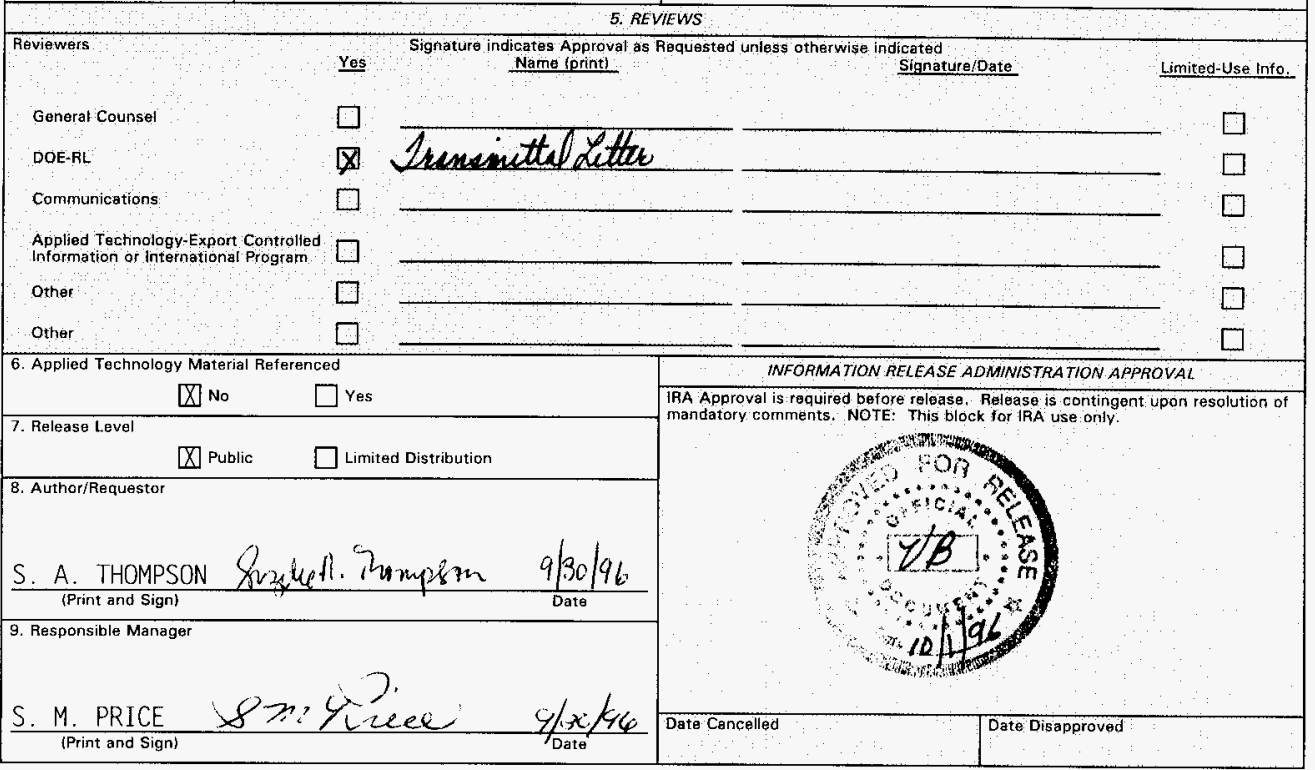


THIS PAGE INTENTIONALLY LE. I' BLANK 


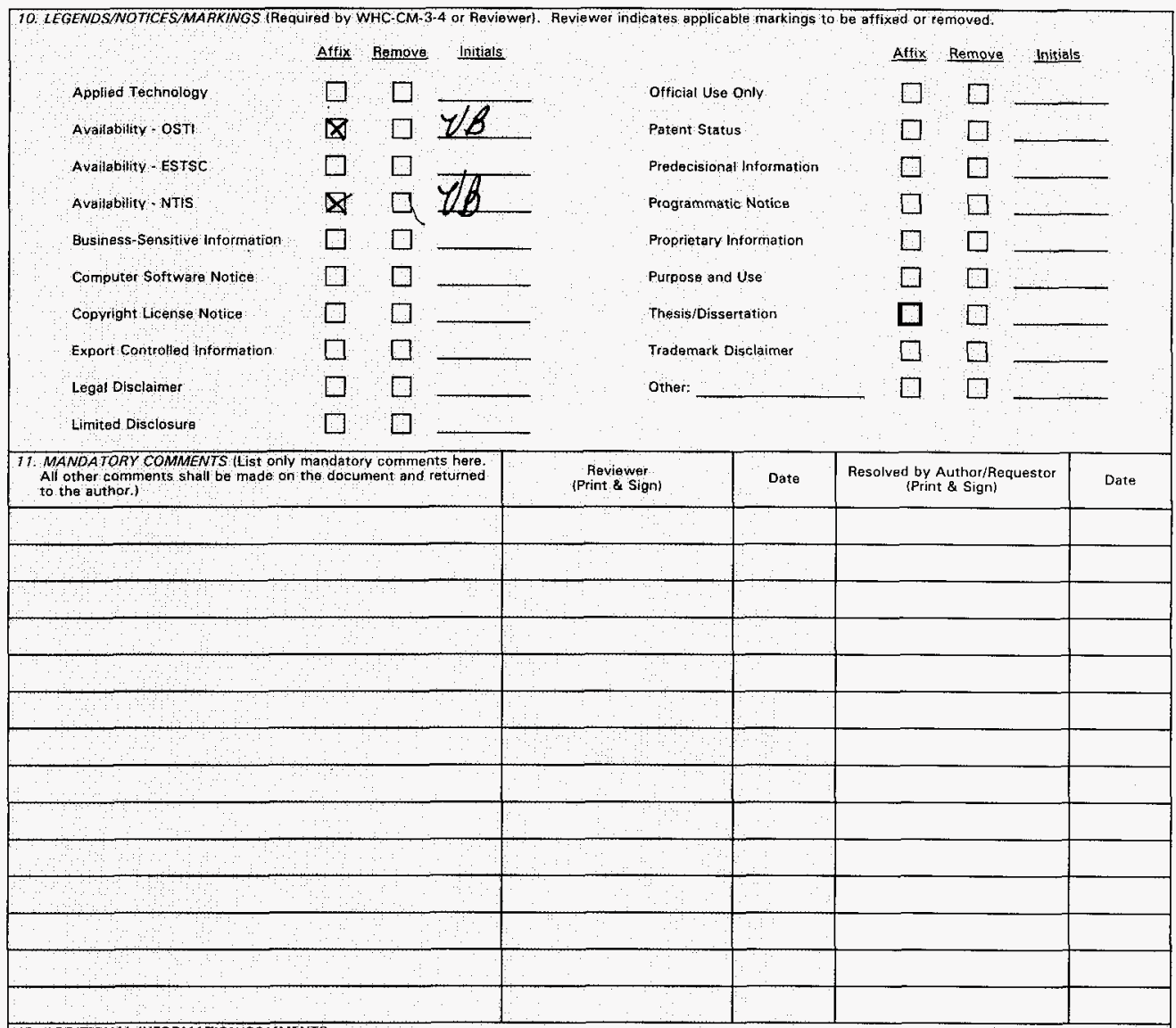


THIS PAGE INTENTIONALLY LEFT BLANK 
Mr. J. E. Rasmussen, Director

Environmental Assurance, Permits, and Policy Division

U.S. Department of Energy

Richland Operations office

Richland, Washington 99352

Dear Mr. Rasmussen:

\section{ANNUAL HANFORD SITE ENVIRONMENTAL PERMITTING STATUS REPORT}

Attached is the finalized "Annual Hanford Site Environmental Permitting Status Report" (Status Report). This Status Report was prepared in response to requirements prescribed in U.S. Department of Energy (DOE) Order 5400.2A, "Environmental Compliance Issue Coordination". This Order, canceled in April 1996, required that information on existing and anticipated environmental permitting for DOE facilities be submitted (or updated) annually by October 1 of each calendar year. Although the Order was canceled, the need for this Status Report still remains. For example, the Washington State Department of Ecology's (Ecology) Dangerous Waste Permit Application Requirements (Publication Number 95-402, June 1996), Check] ist Section J, calls for current information on existing and anticipated environmental permitting. As specified in the Hanford Facility Dangerous Waste Permit Application, General Information Portion (DOE/RL-91-28), this Status Report serves as the vehicle for meeting this requirement for the Hanford Facility.

Development of this Status Report was coordinated by Westinghouse Hanford Company (WHC) and fulfills the Environmental Support Fiscal Year 1996 Multi-Year Program Plan, Work Breakdown Structure 1.5.2 Milestone. This Status Report consolidates WHC input with input received from Bechte] Hanford, Inc. (BHI) and Pacific Northwest National Laboratory (PNNL) for activities managed by these contractors. The Status Report also addresses review comments received from your staff. 
THIS PAGE INTENTIONALLY

LEIT BLANK 
Mr. J. E. Rasmussen

Page 2

September 30, 1996

If you have any questions regarding the contents of this letter or the attachment, please contact Ms. S. M. Price of WHC on (509) 376-1653, Mr. R. J. Landon of BHI on (509) 372-9209, or Mr. H. T. Tilden II of PNNL on (509) 376-0499.

Very truly yours,

Eniploplage fer)

W. T. Dixon, Director

Environmental Services

Westinghouse Hanford Company

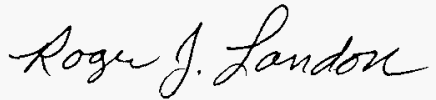

R. J. Landon, Manager Regulatory Support Bechtel Hanford, Inc.

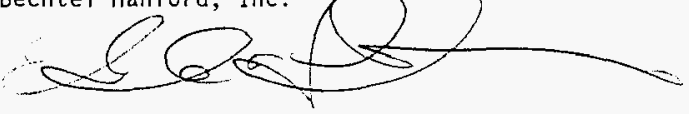

Elizabeth A. Flores, Manager

Environmental Compliance Department

Pacific Northwest National Laboratory

Attachment

$\mathrm{RL}$ - G. M. Bell

C. E. Clark

R. N. Krekel

A. H. Wirkkala (w/o attachment)

BHI - R. J. Landon

L. A. Mihalik

PNNL - E. A. Flores

H. T. Tilden, II 
THIS PAGE INTENTIONALLY

LEFT BLANK 
9654472

ATTACHMENT

ANNUAL HANFORD SITE ENVIRONMENTAL PERMITTING

STATUS REPORT

$$
\text { Consisting of } 326 \text { pages }
$$


THIS PAGE TNTENTIONALLY LEFT BLANK 


\title{
ANNUAL HANFORD SITE ENVIRONMENTAL PERMITTING STATUS REPORT
}

\author{
Executive Summary
}

This Annual Hanford Site Environmental Permitting Status Report (Status Report) was prepared in response to requirements prescribed in U.S. Department of Energy (DOE) Order 5400.2A, "Environmental Compliance Issue Coordination". This Order, canceled in April 1996, required that information on existing and anticipated environmental permitting for DOE facilities be submitted (or updated) annually by October 1 of each calendar year. Although the Order was canceled, the need for this Status Report still remains. For example, the Washington State Department of Ecology's (Ecology) Dangerous Waste Permit Application Requirements (Publication Number 95-402, June 1996), Checklist Section J, calls for current information on existing and anticipated environmental permitting. As specified in the Hanford Facility Dangerous Waste Permit Application, General Information Portion (DOE/RL-91-28), this Status Report serves as the vehicle for meeting this requirement for the Hanford Facility.

This Status Report includes information on all existing and anticipated environmental permitting. Environmental permitting required by the Resource Conservation and Recovery Act (RCRA) of 1976, the Hazardous and Solid Waste Amendments (HSWA) of 1984, and non-RCRA permitting (solid waste handling, Clean Air Act Amendments of 1990, Clean Water Act Amendments of 1987, Washington State waste discharge, and onsite sewage system) are addressed. Information on RCRA and non-RCRA permitting is included and is current as of July 31, 1996.

For the purposes of RCRA and the State of Washington Hazardous Waste Management Act of 1976 [as administered through the Ecology Dangerous Waste Regulations, Washington Administrative Code (WAC) 173-303], the Hanford Facility is considered a single facility. As such, the Hanford Facility has been issued one U.S. Environmental Protection Agency (EPA)/State Identification Number (WA7890008967). This EPA/State identification number encompasses over 60 treatment, storage, and/or disposal (TSD) units. Ecology has been delegated authority by the EPA to administer the RCRA, including mixed waste authority.

The RCRA permitting approach for the Hanford Facility is addressed in the Hanford Federal Facility Agreement and Consent Order (Tri-Party Agreement). Pursuant to the Tri-Party Agreement, a single RCKA permit was issued by Ecology and the EPA to cover the Hanford Facility. The initial Hanford Facility (HF) RCRA Permit was issued for less than the entire Facility because all of the TSD units cannot be permitted simultaneously. The HF RCRA Permit, through the permit modification process, will eventually incorporate all of the TSD units.

The current Hanford Facility Dangerous Waste Part A Permit Application (DOE/RL-88-21) consists of three "Dangerous Waste Permit Application, Form 1s" (submitted at the facility level) and over 60 "Dangerous Waste Permit Application, Form 3s" (submitted for each TSD unit or group of units located on the Hanford Facility). In satisfaction of the Tri-Party Agreement 
Milestone M-20 schedule, Part B dangerous waste permit application and closure plan documentation have been submitted for several Hanford Facility TSD units. Certified Part B dangerous waste permit application documentation for one or more of these TSD units, along with the Hanford Facility Dangerous Waste Permit Application, General Information Portion (DOE/RL-91-28) submitted in October 1991, constituted a complete dangerous waste permit application meeting all requirements of the Tri-Party Agreement, 40 Code of Federal Regulations (CFR) 270.1(c)(4), and WAC 173-303-806. The HF RCRA Permit (Revision 0) became effective on September 28, 1994.

Revision 0 of the HF RCRA Permit is divided into two portions: a Dangerous Waste (DW) Portion issued by Ecology, and a HSWA Portion issued by EPA, Region 10. The DW Portion is issued to four Permittees, DOE, Richland Operations Office (DOE-RL), as the owner/operator, and to three of its contractors, as co-operators. The HSWA Portion is issued to DOE-RL. In November 1994, Ecology was delegated authority for the Correction Action provisions of HSWA. The Corrective Action provisions of HSWA will be incorporated into the HF RCRA Permit (DW Portion) in a future modification.

Revision 0 of the HF RCRA Permit (DW Portion) incorporated five TSD units. Revision 1 of the HF RCRA Permit (DW Portion) that became effective in May 1995, incorporated an additional five TSD units. Revision 2 of the HF RCRA Permit (DW Portion) that became effective in September 1996, incorporated an additional four TSD units. Revision 3 of the HF RCRA Permit (DW Portion), scheduled to become effective in December 1996, will incorporate an additional four TSD units. Additional TSD units will be incorporated into the HF RCRA Permit through annual permit modifications, in accordance with the Permit Modification Schedule, Attachment 27 of the HF RCRA Permit (DW Portion).

Compliance with the Clean Air Act requires facility-specific and also Hanford sitewide compliance activities. At the facility-specific level, each facility that emits constituents regulated by the Clean Air Act must comply as appropriate. This Status Report identifies facility-specific and Hanford sitewide compliance activities and requirements.

At the Hanford sitewide permit level, implementation of the Clean Air Act is facilitated by several permits. A Prevention of Significant Deterioration Permit (PSD-X80-14) was originally obtained to cover the airborne discharge of nitrogen oxides (a criteria pollutant) from now-retired nuclear processing facilities.' Criteria pollutant emissions (e.g., nitrogen oxides, sulfur oxides, and particulate matter less than 10 microns), from the Hanford Site fussil fueled stream-producing powerhouses, continue above the threshold requirements listed under the Clear Air Act. Significant increases in these emissions require an approved modification of the PSD permit.

The Radioactive Air Emissions Program Permit (FF-01) governs the operations of radioactive emissions sources that have the potential to emit equal to or greater than 10 percent of the Derived Concentration Guide values. 
Title $\mathrm{V}$ of the Clean Air requires an air operating permit for major emitting facilities. For the purposes of Title V, the Hanford Site is considered a single facility. As such, the Hanford Site is considered a major source requiring one Title $\mathrm{V}$ permit. The Hanford Site is applying for an air operating permit expected to be completed in October 1997.

The Sitewide National Pollutant Discharge Elimination System Permit (NPDES) (WA-000374-3), and the 300 Area Treated Effluent Disposal Facility NPDES Permit (WA-002591-7), govern liquid process effluent discharges to the Columbia River. The NPDES Storm Water General Permit (WA-R-000-00F) governs storm water discharges to the Columbia River.

Consent Order DE 91NM-177, a legal document signed by the DOE-RL and Ecology on December 23, 1991, provides compliance milestones for the liquid effluents discharged to the ground. These milestones include the submittal of Washington State Waste Discharge Permit applications and other compliance documentation for streams that discharge to the ground. Other Hanford Site permitting addressed in this report includes RCRA research, development, and demonstration (RD\&D), solid waste handling, onsite sewage system, and petroleum underground storage tank permitting. 


\section{ANNUAL HANFORD SITE \\ ENVIRONMENTAL PERMITTING STATUS REPORT}

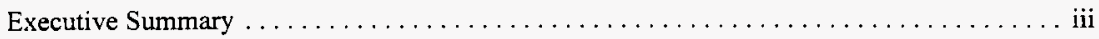

\section{RESOURCE CONSERVATION AND RECOVERY ACT PERMITTING PART A AND PART B PERMITTING}

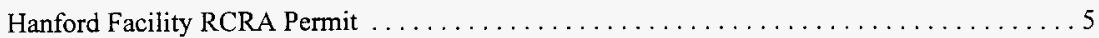

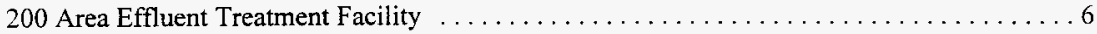

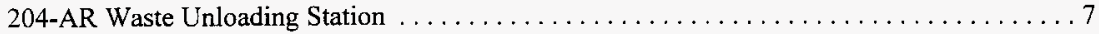

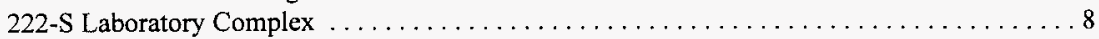

224-T Transuranic Waste Storage and Assay Facility . . . . . . . . . . . . . . . . 9

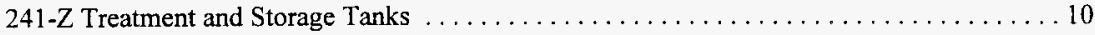

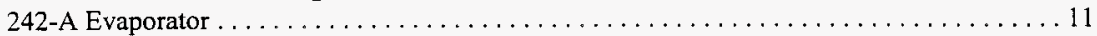

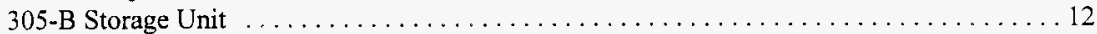

325 Hazardous Waste Treatment Units . . . . . . . . . . . . . . . . . . . . . 13

600 Area Purgewater Storage and Treatment Facility .......................... 14

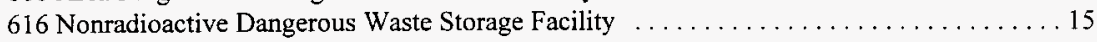

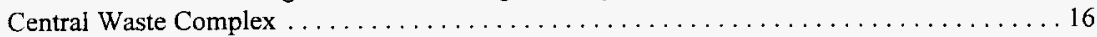

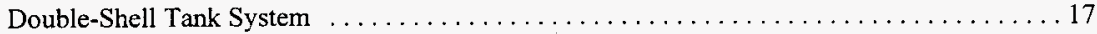

Grout Treatment Facility . . . . . . . . . . . . . . . . . . . . . . . . . . . 18

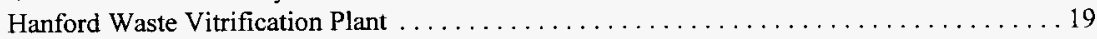

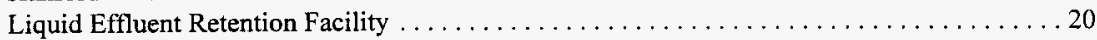

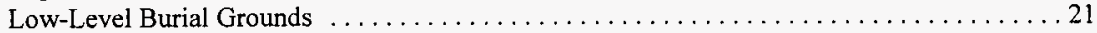

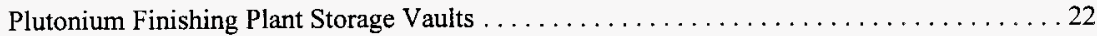

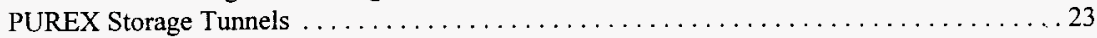

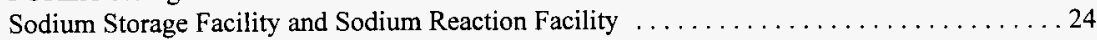

T Plant Complex ............................................. 25

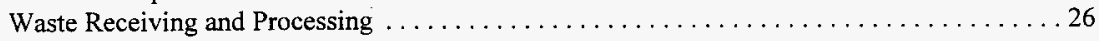

\section{RESOURCE CONSERVATION AND RECOVERY ACT PRÓCEDURAL CLOSURE PERMITTING}

221-T Containment Systems Test Facility . . . . . . . . . . . . . . . . . . . 29

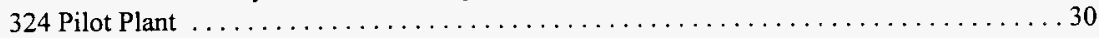

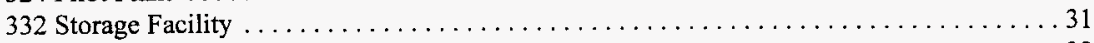

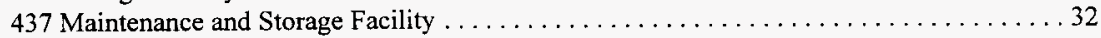

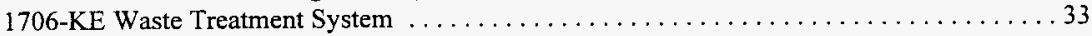

2727-WA Sodium Reactor Experiment Sodium Storage Building $\ldots \ldots \ldots \ldots \ldots \ldots \ldots \ldots$

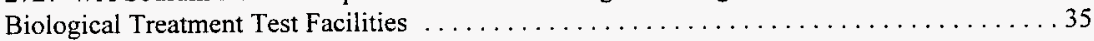




\section{RESOURCE CONSERVATION AND RECOVERY ACT \\ PROCEDURAL CLOSURE PERMITTING (cont.)}

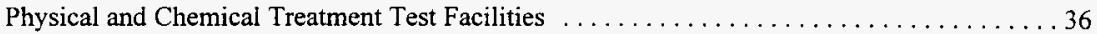

Thermal Treatment Test Facilities ................................. 37

\section{RESOURCE CONSERVATION AND RECOVERY ACT RESEARCH, DEVELOPMENT, AND DEMONSTRATION PERMITTING}

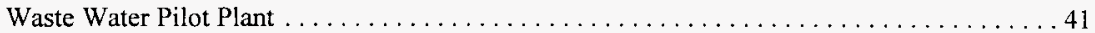

\section{TOXIC SUBSTANCES CONTROL ACT PERMITTING}

Graphite Electrode DC Arc Plasma Furnace, 324 Building $\ldots \ldots \ldots \ldots \ldots \ldots \ldots \ldots$

Low-Level Burial Grounds

\section{RESOURCE CONSERVATION AND RECOVERY ACT CLOSURE PLANS}

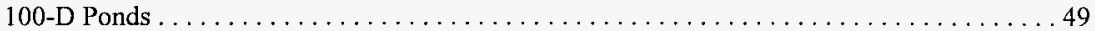

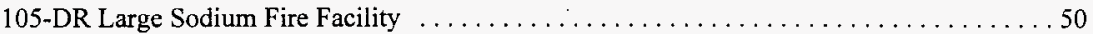

183-H Solar Evaporation Basins . ................................. 51

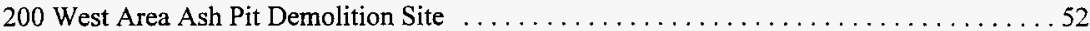

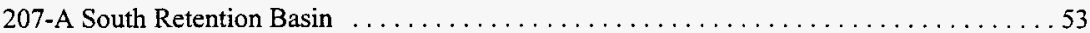

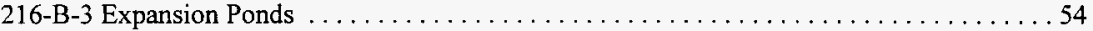

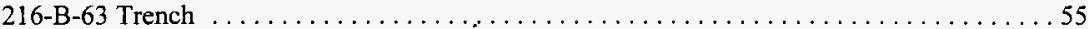

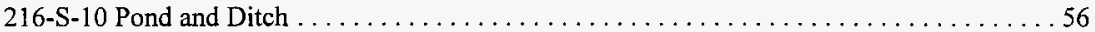

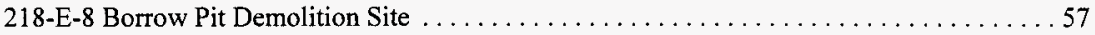

300 Area Solvent Evaporator . . . . . . . . . . . . . . . . . . . . . . . . 58

300 Area Waste Acid Treatment System . . . . . . . . . . . . . . . . . . . . . . . . 59

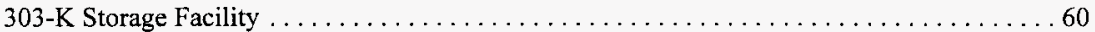

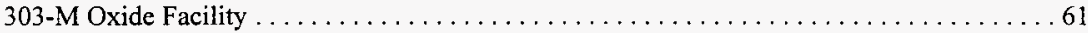

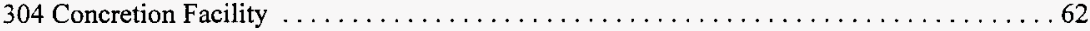

1324-N Surface Impoundment . . . . . . . . . . . . . . . . . . . . . . . . 63

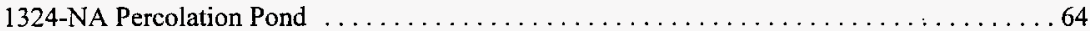

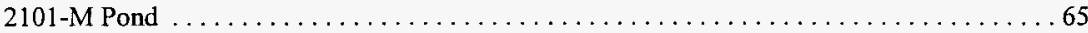

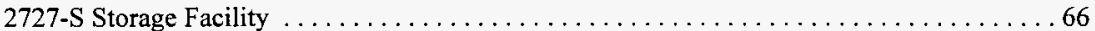

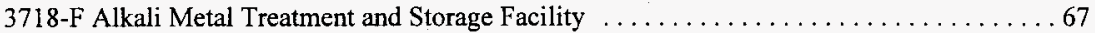

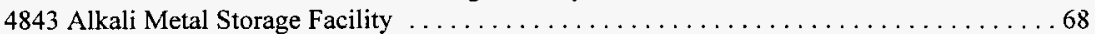

B Plant Complex ............................................. 69

Hanford Patrol Academy Demolition Sites $\ldots \ldots \ldots \ldots \ldots \ldots \ldots \ldots \ldots \ldots \ldots \ldots$ 


\section{RESOURCE CONSERVATION AND RECOVERY ACT \\ CLOSURE PLANS (cont.)}

Hexone Storage and Treatment Facility $\ldots \ldots \ldots \ldots \ldots \ldots \ldots \ldots \ldots \ldots \ldots \ldots \ldots \ldots \ldots$

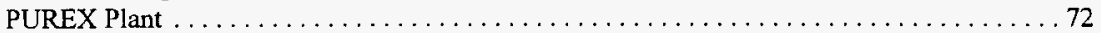

Simulated High-Level Waste Slurry Treatment/Storage $\ldots \ldots \ldots \ldots \ldots \ldots \ldots \ldots \ldots$

\section{RESOURCE CONSERVATION AND RECOVERY ACT}

CLOSURE AND POSTCLOSURE PLANS

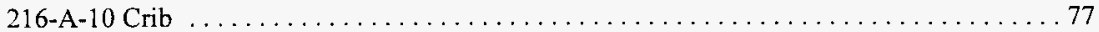

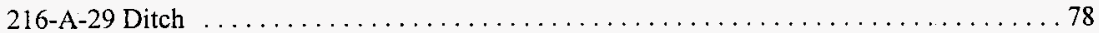

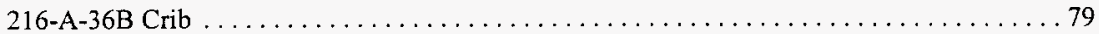

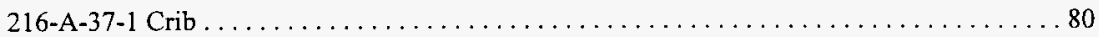

216-B-3 Main Pond and 216-B-3-3 Ditch . . . . . . . . . . . . . . . . 81

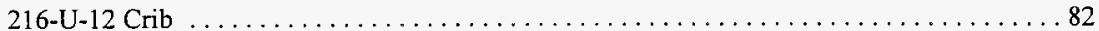

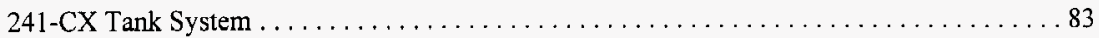

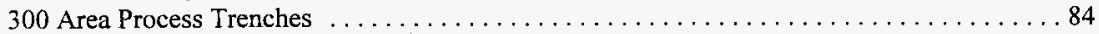

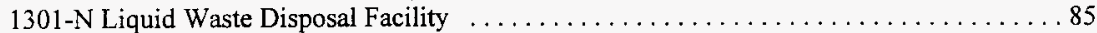

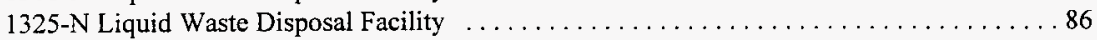

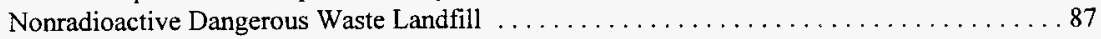

\section{RESOURCE CONSERVATION AND RECOVERY ACT CORRECTIVE ACTION WORK PLAN}

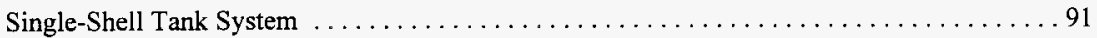

\section{RCRA DELISTING PETITION}

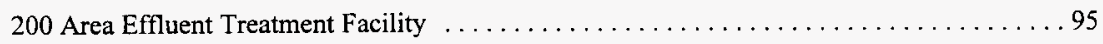

\section{SOLID WASTE HANDLING PERMITTING}

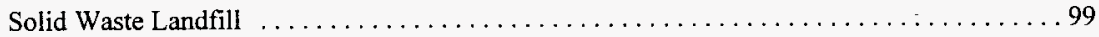

\section{CLEAN AIR ACT PERMITTING}

Hanford Site (Radioactive Air Emissions Program) $\ldots \ldots \ldots \ldots \ldots \ldots \ldots \ldots \ldots \ldots . \ldots \ldots$

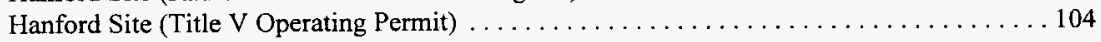




\section{CLEAN AIR ACT PERMITTING (cont.)}

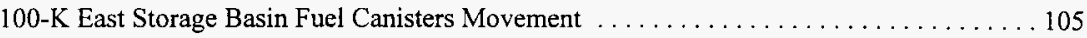

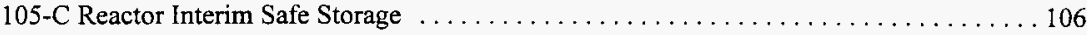

105-C Reactor Interim Safe Storage ............................... . 107

100-D Ponds Excavation of Radiologically Contaminated Soil . . . . . . . . . . . . 108

100-D Ponds Excavation of Radiologically Contaminated Soil . . . . . . . . . . . . . . 109

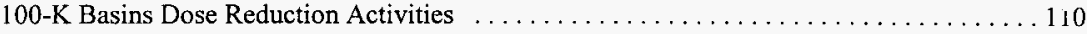

$100-\mathrm{K}$ Basins Phase 2 Characterization . . . . . . . . . . . . . . . . . . . 111

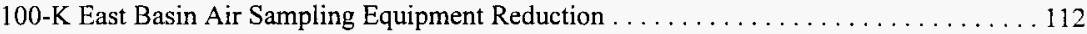

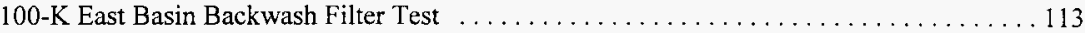

$100-\mathrm{N}$ Basin Water Processing in the 200 Area Effluent Treatment Facility . . . . . . . . . 114

105-K East Basin Debris Removal . . . . . . . . . . . . . . . . . . . . . . . . . . 115

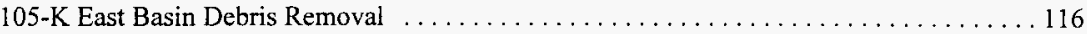

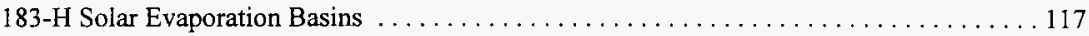

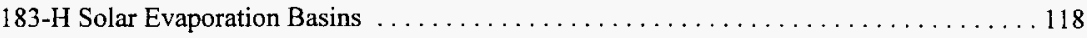

183-K East Radiological Counting Lab Relocated to $1706-K$ East Facility . . . . . . . . . . 119

200 Area Diesel Generators . . . . . . . . . . . . . . . . . . . . . . . . . . . . 120

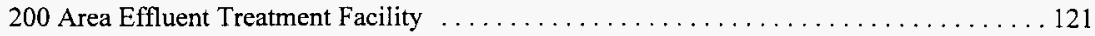

200 Area Effluent Treatment Facility . . . . . . . . . . . . . . . . . . . . 122

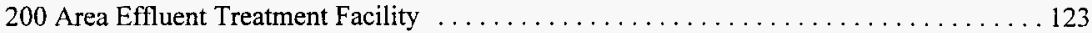

219-S Sample Gallery to 204-AR Waste Unloading Station Waste Transfers . . . . . . . . 124

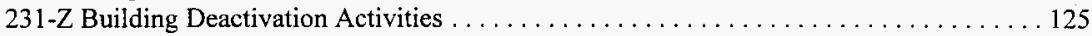

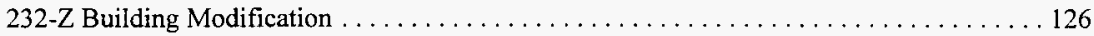

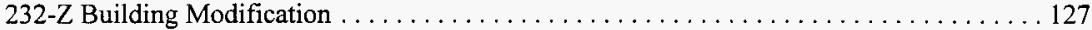

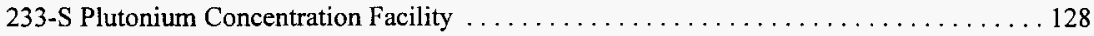

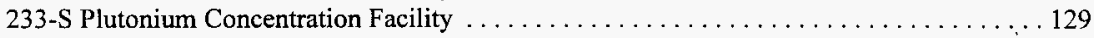

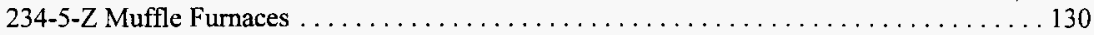

244-CR Vault Double-Contained Receiver Tank . . . . . . . . . . . . . . . . . 131

300 Area Treated Effluent Disposal Facility . . . . . . . . . . . . . . . . . . . 132

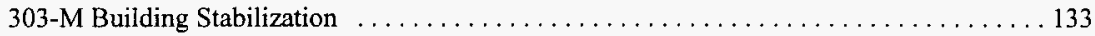

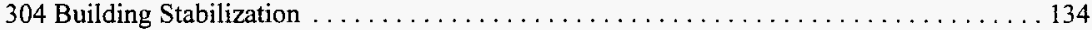

$305-B$ Storage Facility . . . . . . . . . . . . . . . . . . . . . . . . 135

306-E Building High-Efficiency Particulate Air Filter Testing Method . . . . . . . . . . 136

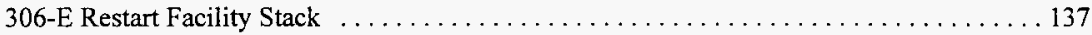

313 Facility Uranium-Bearing System Removal . . . . . . . . . . . . . . . . . . . 138

313 Facility Residue Removal .................................... 139

318 Building High-Efficiency Particulate Air Filter Removal . . . . . . . . . . . . . 140

324 Building Hood Installation ................................ 141

331 High-Efficiency Particulate Air Filter Bank Remova . . . . . . . . . . . . . . . . 142

340-DECON Stack Pollution Control Equipment Modification $\ldots \ldots \ldots \ldots \ldots \ldots \ldots \ldots$

1303-N Fuel Spacer Silos . . . . . . . . . . . . . . . . . . . . . . . . . . . . 144

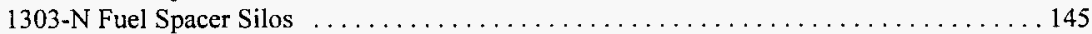

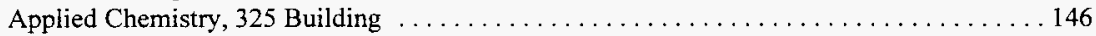




\section{CLEAN AIR ACT PERMITTING (cont.)}

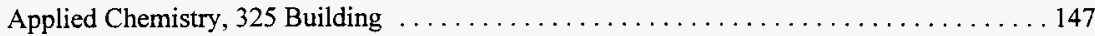

B Plant Canyon Exhaust Tunnel and D-Cell Video Inspection and Dose Measurements . . . . 148

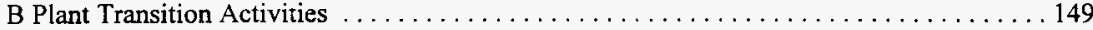

B Plant Vacuum Loader (The Guzzler) . . . . . . . . . . . . . . . . . . . 150

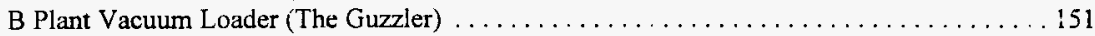

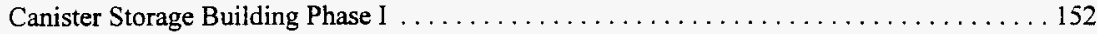

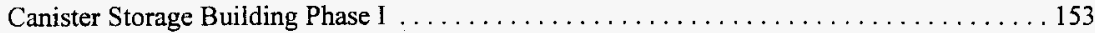

Central Waste Complex and Enhanced Radioactive and Mixed Waste Storage, Phase IV . . . 154

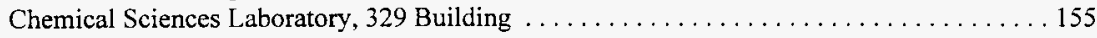

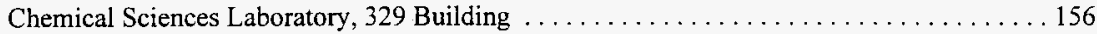

Chemical Sciences Laboratory, 329 Building . . . . . . . . . . . . . . . . 157

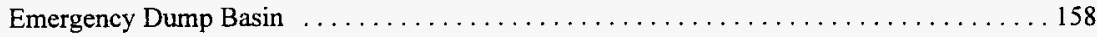

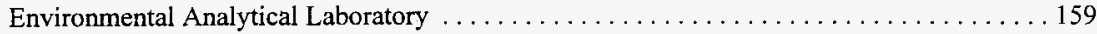

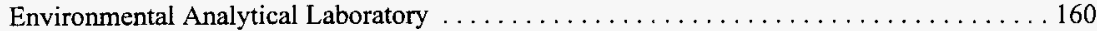

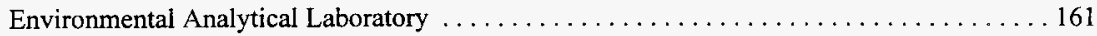

Environmental Analytical Laboratory High-efficiency Particulate Air Filter Addition . . . . 162

Environmental Molecular Sciences Laboratory . . . . . . . . . . . . . . . . . . . 163

Environmental Molecular Sciences Laboratory . . . . . . . . . . . . . . . . . . . . 164

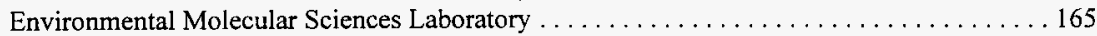

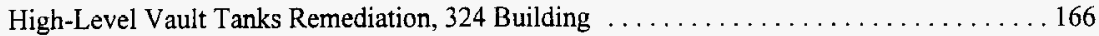

High-Level Vault Tanks Remediation, 324 Building . ........................ 167

Inactive Miscellaneous Underground Storage Tanks Sampling/Characterization . . . . . . . 168

Initial Tank Retrieval System for $241-$ SY-102 Tank . . . . . . . . . . . . . . . . . 169

Initial Tank Retrieval System for 241-SY-102 Tank ..................... 170

Low-Level Burial Grounds Mixed Waste Disposal Trench 34 Leachate Collection Tank . . . . 171

Operation of Portable Exhauster in Conjunction with the Light Duty Utility Arm . . . . . . . 172

Operation of a Portable Exhauster in Conjunction with the Light Duty Utility Arm . . . . . . 173

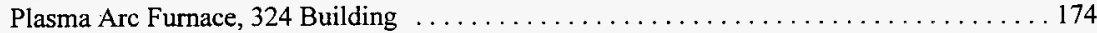

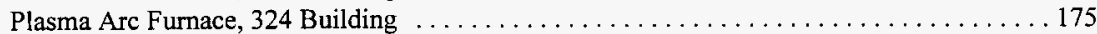

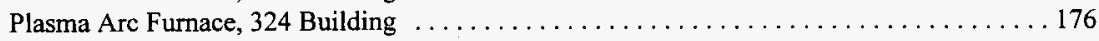

Plutonium Finishing Plant Cementation of Plutonium Bearing Materials $\ldots \ldots \ldots \ldots \ldots 177$

Plutonium Finishing Plant Duct Work and Process Piping Remediation $\ldots \ldots \ldots \ldots \ldots 178$

Plutonium Finishing Plant Low-Level Waste Treatment Facility . . . . . . . . . . . . . . 179

Plutonium Recycle Test Reactor Vault Cleanout $\ldots \ldots \ldots \ldots \ldots \ldots \ldots \ldots \ldots \ldots \ldots \ldots$

Plutonium Recycle Test Reactor Vault Cleanout $\ldots \ldots \ldots \ldots \ldots \ldots \ldots \ldots \ldots \ldots \ldots \ldots \ldots$

Portable Exhausters . ....................................... 182

Portable Exhauster for Flammable Watchlist Single-Shell Tank System $\ldots \ldots \ldots \ldots \ldots \ldots 183$

Portable Exhauster for Flammable Watchlist Single-Shell Tank System . . . . . . . . . . . . 184

Portable/Temporary Radioactive Air Emission Units Annual Reporting Change . . . . . . . 185

PUREX Plant Deactivation . . . . . . . . . . . . . . . . . . . . . . . . . . 186

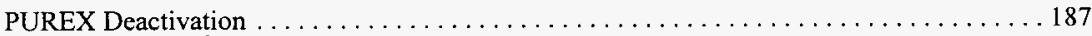

PUREX Plant Fuel Transfer to the $105-\mathrm{KW}$ Basin $\ldots \ldots \ldots \ldots \ldots \ldots \ldots \ldots \ldots \ldots \ldots \ldots$ 


\section{CLEAN AIR ACT PERMITTING (cont.)}

PUREX Plant Fuel Transfer to the 105-KW Basin . . . . . . . . . . . . . . . . . . . 189

PUREX Stack Monitoring and Sampling Requirements Modification .............. 190

PUREX $\mathrm{UO}_{3}$ Fuel Processing . . . . . . . . . . . . . . . . . . . . . . . . . . 191

PUREX Use of Kelly Vacuum as a Portable, Temporary Radioactive Air Emission Unit . . 192

Radon Research Facility, 331 Building . . . . . . . . . . . . . . . . . . . . . 193

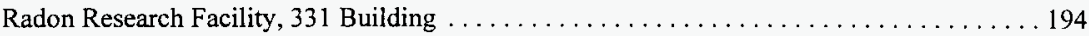

Radon Generator Facility Relocation to Any Location Onsite . . . . . . . . . . . . . . . 195

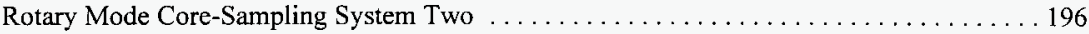

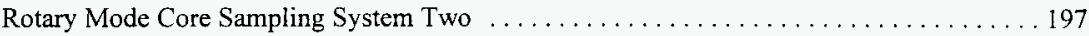

Rotary Mode Core Sampling Systems Two ........................... 198

Rotary Mode Core-Sampling Systems Two, Three, and Four . . . . . . . . . . . . . . 199

Rotary Mode Core Sampling Systems Two, Three, and Four . . . . . . . . . . . . 200

Rotary Mode Core Sampling Systems Two, Three, and Four .................. 201

Sodium Storage Facility ........................................ 202

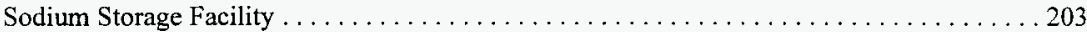

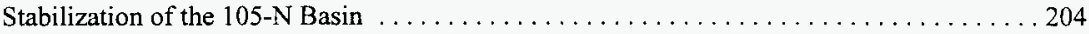

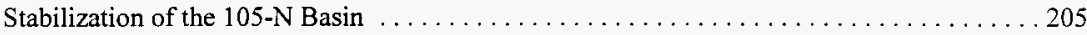

Steam Plant Rehabilitation, Phase II ............................ 206

Storage of the Liquid Waste Tank Cars and the 324 Building Waste in the

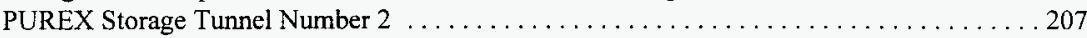

Storage of the Liquid Waste Tank Cars and the 324 Building Waste in the

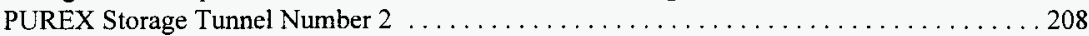

Tank 241-A-101 Portable Exhauster . . . . . . . . . . . . . . . . . . . . . . . . . . 209

Tank 241-A-101 Portable Exhauster . . . . . . . . . . . . . . . . . . . . . . 210

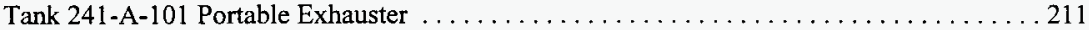

Tank 241-AZ-101 Waste Retrieval and 241-AY/241-AZ Tank Farms

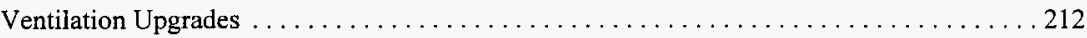

Tank 241-AZ-101 Waste Retrieval and 241-AY/241-AZ Tank Farms

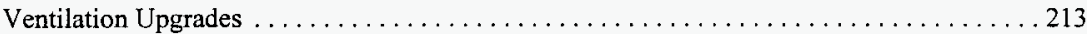

Tank 241-AZ-101 Waste Retrieval and 241-AY/241-AZ Tank Farms

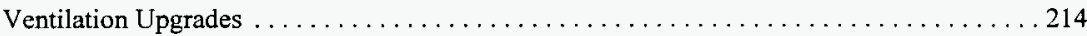

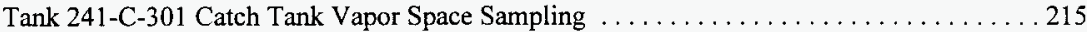

Tank 241-C-103 Organic Removal .................................... 216

Tank 241-C-103 Organic Removal ................................... 217

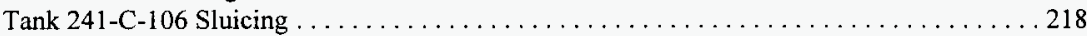

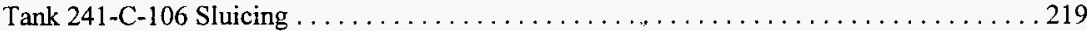

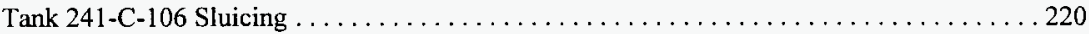

Tank Farm 241-S Removal of Duct Work and Associated Exhausters . . . . . . . . . . . 221

Tank Farm 241-S Removal of Duct Work and Associated Exhausters . . . . . . . . . . . 222

Tank 241-SY-101 Mixer Pump Replacement . . . . . . . . . . . . . . . . . . . . 223

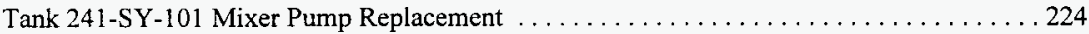

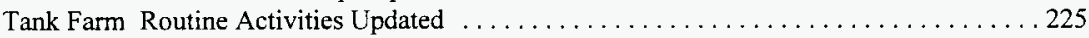




\section{CLEAN AIR ACT PERMITTING (cont.)}

T Plant Long-Length Contaminated Equipment Grouting and Microencapsulation . . . . . . 226

T Plant Secondary Containment and Leak Detection Upgrades . . . . . . . . . . . . . 227

Transfer and Receipt of Waste in the 324 Building for Storage in

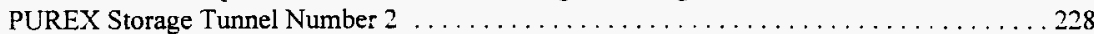

Transfer and Receipt of Waste in the 324 Building for Storage in

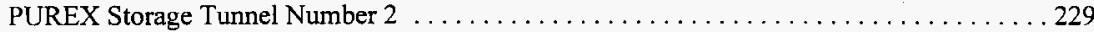

UP-1 Groundwater Processing in the 200 Area Effluent Treatment Facility . . . . . . . . 230

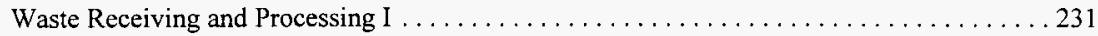

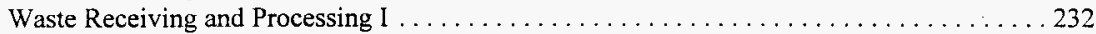

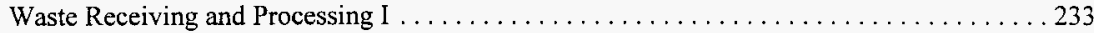

Waste Receiving and Processing 1 Stack No. 296-W-004 Monitoring

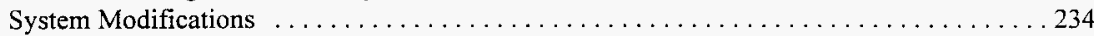

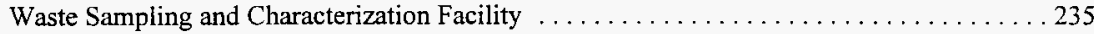

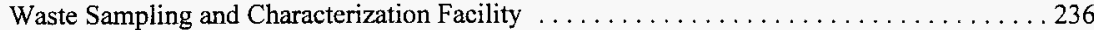

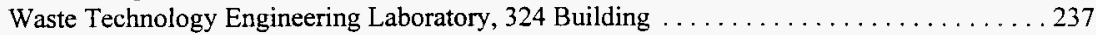

Waste Encapsulation and Storage Facility K-3 Duct Characterization and Washdown . . . . 238

Waste Encapsulation and Storage Facility K-3 Duct Characterization and Washdown . . . . . 239

\section{CLEAN WATER ACT PERMITTING}

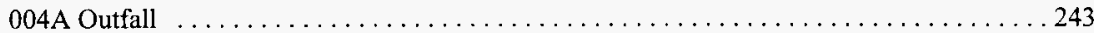

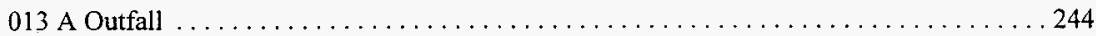

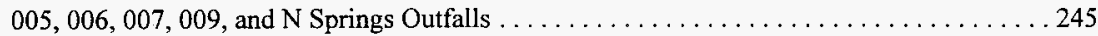

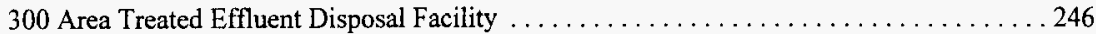

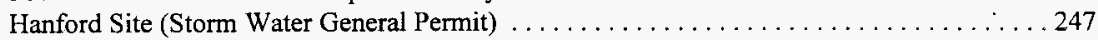

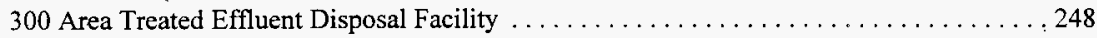

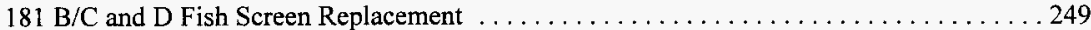

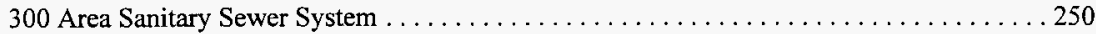

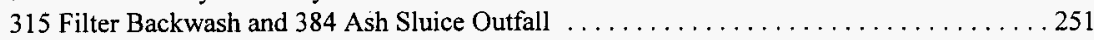

Environmental Molecular Science Laboratory . . . . . . . . . . . . . . . . . . 252

\section{NATIONAL PARK SERVICE REVIEW PERMITTING}

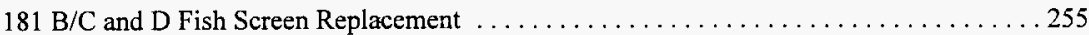

\section{AQUATIC LANDS LEASE PERMITTING}

300 Area Treated Effluent Disposal Facility . . . . . . . . . . . . . . . . . . 259 


\section{HYDRAULIC PROJECT APPROVAL PERMITTING}

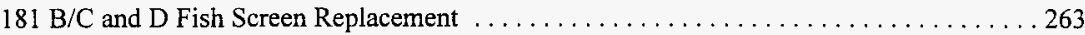

$181-K$ East Fish Screen Replacement .............................. 264

\section{WATER QUALITY STANDARDS MODIFICATION PERMITTING}

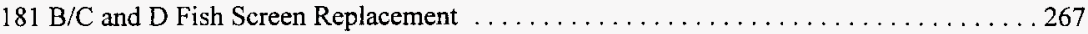

$181-K$ Fish Screen Replacement . . . . . . . . . . . . . . . . . . . . . . . . . 268

\section{STATE WASTE DISCHARGE PERMITTING}

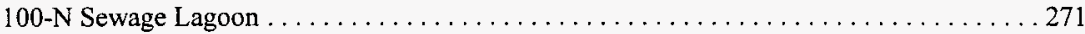

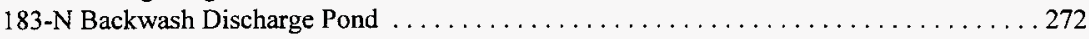

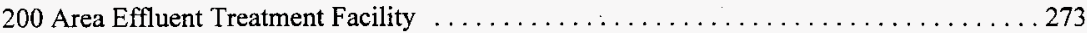

200 Area Treated Effluent Disposal Facility . . . . . . . . . . . . . . . . . . . . 274

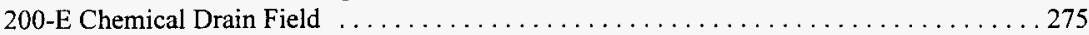

$200-E$ Powerhouse Ash Pit . . . . . . . . . . . . . . . . . . . . . . . . 276

200-W Powerhouse Ash Pit . . . . . . . . . . . . . . . . . . . . . . . . . . . . . 277

300 Area Ash Sluice Pond No. 2, Retrieval Technology Testing . . . . . . . . . . . . . . 278

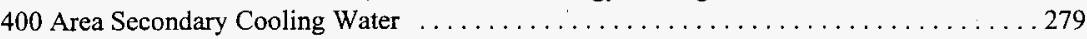

400 Area Septic System . . . . . . . . . . . . . . . . . . . . . . . . . . 280

Cooling Water and Condensate Discharges ........................... 281

Hydrotesting, Construction, and Maintenance Discharges $\ldots \ldots \ldots \ldots \ldots \ldots \ldots \ldots 282$

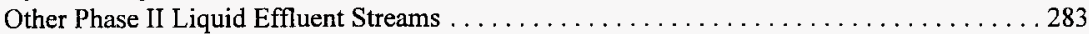

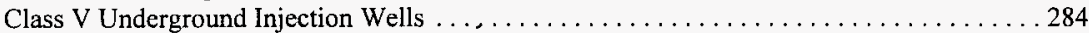

\section{ONSITE SEWAGE SYSTEM PERMITTING}

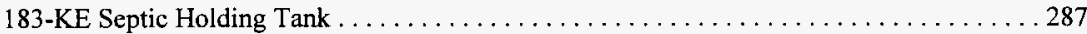

200 Area Effluent Treatment Facility Septic Holding Tanks $\ldots \ldots \ldots \ldots \ldots \ldots \ldots . \ldots . \ldots . \ldots 288$

222-S Laboratory Complex, Septic Holding Tank $\ldots \ldots \ldots \ldots \ldots \ldots \ldots \ldots \ldots \ldots \ldots . \ldots \ldots$

1607-K4 Septic Tank . . . . . . . . . . . . . . . . . . . . . . . . . . . . . . 290

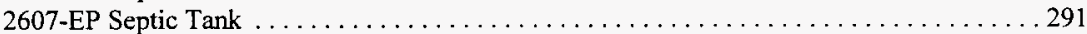

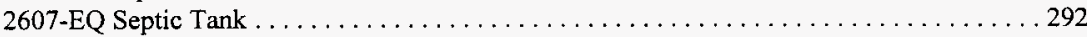

2607-E10 Septic Tank .......................................... 293

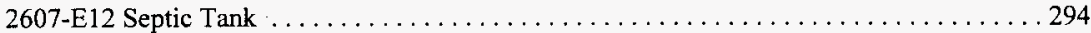

2607-WA East Septic Tank . . . . . . . . . . . . . . . . . . . . . . . . . 295

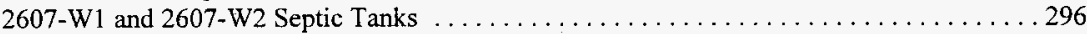

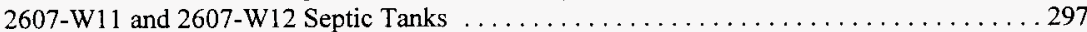




\section{ONSITE SEWAGE SYSTEM PERMITTING (cont.)}

2607-W14 Septic Tank . . . . . . . . . . . . . . . . . . . . . . . . 298

2607-W15 Septic Tank ........................................... 299

$6607-9$ Septic Tank . . . . . . . . . . . . . . . . . . . . . . . . . . . . . . 300

$6607-11$ Septic Tank ............................................... 301

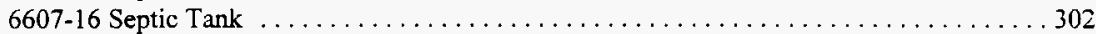

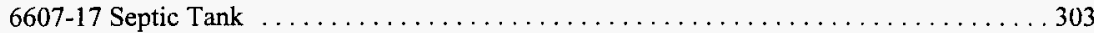

Environmental Molecular Sciences Laboratory Temporary Septic Holding Tank . . . . . . 304

\section{PETROLEUM UNDERGROUND STORAGE TANK PERMITTING}

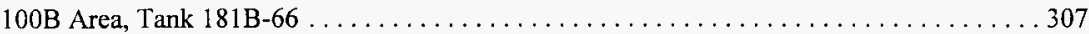

200 East Area, Tank 204-AR . . . . . . . . . . . . . . . . . . . . . . . . . 308

200 East Area, Tank 241-A-701 . . . . . . . . . . . . . . . . . . . . . . . . . . 309

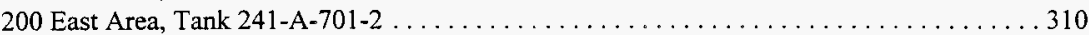

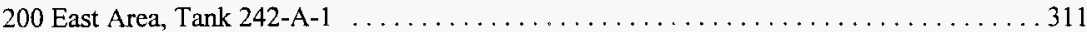

200 East Area, Tank $244-A R$. . . . . . . . . . . . . . . . . . . . . . . . . . . . 312

200 East Area, Tank $281-\mathrm{A}-1$. . . . . . . . . . . . . . . . . . . . . . . . . . 313

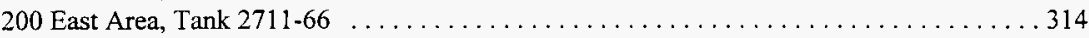

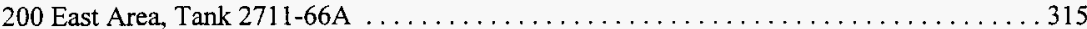

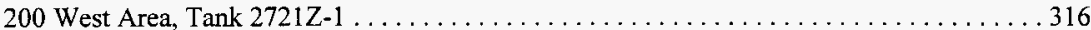

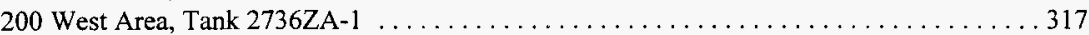

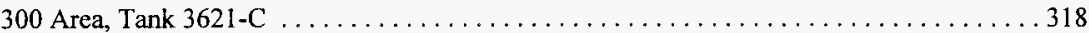

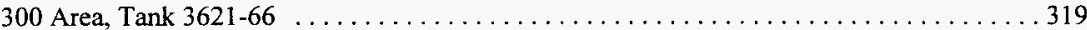

400 Area, Tank $400-$ FFTF-T303 . . . . . . . . . . . . . . . . . . . . . . 320

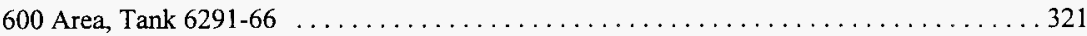

600 Area, Tank $6291-66$ A . . . . . . . . . . . . . . . . . . . . . . . . 322

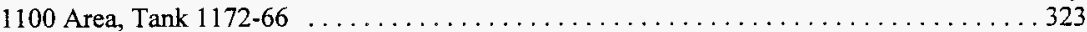

1100 Area, Tank $1172-66$ A . . . . . . . . . . . . . . . . . . . . . . 324

\section{REFERENCES}

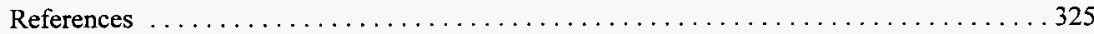




\section{ACRONYMS}

CFR

DOE

DOE-RL

DW

Ecology

EPA

HF RCRA Permit

HSWA

N/A

NESHAPS

NPDES

PSD

PUREX

RCRA

RD\&D

TBD

Tri-Party Agreement

TSCA

TSD

WAC

WPPSS
Code of Federal Regulations

U.S. Department of Energy

U.S. Department of Energy, Richland Operations Office dangerous waste

Washington State Department of Ecology

U.S. Environmental Protection Agency

Hanford Facility RCRA Permit

Hazardous and Solid Waste Amendments

not applicable

National Emission Standards for Hazardous Air Pollutants

National Pollutant Discharge Elimination System

Prevention of Significant Deterioration

plutonium-uranium extraction

Resource Conservation and Recovery Act of 1976

research, development, and demonstration

to be determined

Hanford Federal Facility Agreement and Consent Order

Toxic Substances Control Act

treatment, storage, and/or disposal

Washington Administrative Code

Washington Public Power Supply System 
DOE/RL-96-63, Rev. 0

$10 / 96$

This page intentionally left blank. 
DOE/RL-96-63, Rev. 0

$10 / 96$

RESOURCE CONSERVATION AND RECOVERY ACT PERMITTING 
DOE/RL-96-63, Rev. 0

$10 / 96$

This page intentionally left blank. 
DOE/RL-96-63, Rev. 0 $10 / 96$

\section{PART A AND PART B PERMITTING}


DOE/RL-96-63, Rev. 0

$10 / 96$

This page intentionally left blank. 
The following information was prepared in response to requirements of DOE Order 5400.2A.

DOE Operations Office: Richland

DOE Facility: Hanford Site

Existing Permit (X) Renewal ( ) New Permit ( )

Permit Type: RCRA

Permitting Agency: Washington State Department of Ecology

Permit Number: WA7890008967

Permitted Unit: Hanford Facility RCRA Permit

Issuance Date: September 28, 1994 (Date Revision 0 of the HF RCRA Pemmit became effective. 30 days affer pemit issuance),

Expiration Date: September 27, 2004

Need for Headquarters' Action

(for permit renewals or new permits)
Yes ( ) No ( $\mathrm{X})$

If yes, HQ Program Element

Brief Summary of Relevant Information (major permit conditions, status of compliance or unusual problems):

The initial HF RCRA Permit (Revision 0) was issued by Ecology and the EPA on August 29, 1994, and became effective on September 28, 1994. The HF RCRA. Permit governs all final status TSD activities on the Hanford Facility. Revision 0 of the HF RCRA Permit (DW Portion) incorporated five TSD units: 616 Nonradioactive Dangerous Waste Storage Facility, 300 Area Solvent Evaporator, 2727-S Nonradioactive Dangerous Waste Storage Facility, 305-B Storage Facility, and 183-H Solar Evaporator Basins. Revision 1 of the HF RCRA Permit (DW Portion) that became effective on May 29, 1995, incorporated five TSD units: 218-E-8 Borrow Pit Demolition Site, 200 West Area Ash Pit Demolition Site, 216-B-3 Expansion Ponds, 2101-M Pond, and Simulated High-Level Waste Slurry Treatment and Storage. Revision 2 of the HF RCRA Permit (DW Portion) that became effective on September 28, 1995, incorporated three TSD units: Hanford Patrol Academy Demolition Sites, 105-DR Large Sodium Fire Facility, and 304 Concretion Facility. Revision 3 of the HF RCRA Permit (DW Portion) is scheduled to become effective in December 1996, and will incorporate four TSD units: PUREX Storage Tunnels, 300 Area Process Trenches, 3718-F Alkali Metal Treatment, and 4843 Alkali Metal Storage.

Prepared by: Westinghouse Hanford Company Environmental Services 
The following information was prepared in response to requirements of DOE Order 5400.2A.

DOE Operations Office: Richland

DOE Facility: Hanford Site

Existing Permit ( ) Renewal ( ) New Permit (X)

Permit Type: RCRA

Permitting Agency: Washington State Department of Ecology

Permit Number: WA7890008967

Permitted Unit: 200 Area Effluent Treatment Facility

Issuance Date:

Expiration Date:

Need for Headquarters' Action

(for permit renewals or new permits)
Yes ( ) No (X)

If yes, HQ Program Element

Brief Summary of Relevant Information (major permit conditions, status of compliance or unusual problems):

Part A, Form 3, dangerous waste permit application documentation for the 200 Area Effluent Treatment Facility originally was submitted to Ecology and the EPA in June 1991. One revision of the Part A, Form 3, dangerous waste permit application documentation has been submitted.

Tri-Party Agreement Milestone M-20-50 was satisfied with the submittal of the Part B dangerous waste permit application documentation to Ecology and the EPA on August 31, 1993. Workshops are ongoing with Ecology to finalize Revision 1 of the 200 Area Effluent Treatment Facility Part B Dangerous Waste Permit Application documentation. The 200 Area Effluent Treatment Facility is scheduled to be incorporated into the HF RCRA Permit (DW Portion) in Modification C, December 1997.

Prepared by: Westinghouse Hanford Company

Date: July 31,1996

Environmental Services 
The following information was prepared in response to requirements of DOE Order 5400.2A.

DOE Operations Office: Richland

DOE Facility: Hanford Site

Existing Permit ( ) $\quad$ Renewal ( ) New Permit (X)

Permit Type: RCRA

Permitting Agency: Washington State Department of Ecology

Permit Number: WA7890008967

Permitted Unit: 204-AR Waste Unloading Station

Issuance Date:

Expiration Date:

Need for Headquarters' Action

(for permit renewals or new permits)

\section{Yes ( ) No ( X)}

If yes, HQ Program Element

Brief Summary of Relevant Information (major permit conditions, status of compliance or unusual problems):

Part A, Form 3, dangerous waste permit application documentation for the 204-AR Waste Unloading Station originally was submitted to Ecology and the EPA in November 1987. Three revisions of the Part A, Form 3, dangerous waste permit application documentation have been submitted.

The 204-AR Waste Unloading Station will be added to Revision 1 of the Hanford Facility Dangerous Waste Permit Application, Double-Shell Tank System documentation. The Double-Shell Tank System is scheduled to be incorporated into the HF RCRA Permit (DW Portion) in Modification E, calendar year 1999.

Prepared by: Westinghouse Hanford Company

Date: July 31,1996 Environmental Services 
The following information was prepared in response to requirements of DOE Order 5400.2A.

DOE Operations Office: Richland

DOE Facility: Hanford Site

Existing Permit ( ) Renewal ( ) New Permit (X)

Permit Type: RCRA

Permitting Agency: Washington State Department of Ecology

Permit Number: WA7890008967

Permitted Unit: 222-S Laboratory Complex

Issuance Date:

Expiration Date:

Need for Headquarters' Action

(for permit renewals or new permits)
Yes ( ) No ( $\mathrm{X}$ )

If yes, HQ Program Element

Brief Summary of Relevant Information (major permit conditions, status of compliance or unusual problems):

Part A, Form 3, dangerous waste permit application documentation for the 222-S Laboratory Complex originally was submitted to Ecology and the EPA on November 25, 1987. Three revisions of the Part A, Form 3, dangerous waste permit application documentation have been submitted.

Tri-Party Agreement Milestone M-20-22 was satisfied with the submittal of the Part B dangerous waste permit application documentation to Ecology and the EPA in December 1991. All Notice of Deficiency comments received from the regulators have been resolved. The 222-S Laboratory Complex is scheduled to be incorporated into the HF RCRA Permit (DW Portion) in Modification E, calendar year 1999.

Prepared by: Westinghouse Hanford Company

Date: July 31, 1996

\section{Environmental Services}


The following information was prepared in response to requirements of DOE Order $5400.2 \mathrm{~A}$.

DOE Operations Office: Richland

DOE Facility: Hanford Site

Existing Permit ( ) Renewal ( ) New Permit (X)

Permit Type: RCRA

Permitting Agency: Washington State Department of Ecology

Permit Number: WA7890008967

Permitted Unit: 224-T Transuranic Waste Storage and Assay Facility

Issuance Date:

Expiration Date:

Need for Headquarters' Action

(for permit renewals or new permits)
Yes ( ) No (X)

If yes, HQ Program Element

Brief Summary of Relevant Information (major permit conditions, status of compliance or unusual problems):

Part A, Form 3, dangerous waste permit application documentation for the 224-T Transuranic Waste Storage and Assay Facility originally was submitted to Ecology and the EPA in November 1987. Five revisions of the Part A, Form 3, dangerous waste permit application documentation have been submitted.

Tri-Party Agreement Milestone M-20-23 was satisfied with the submittal of the Part B dangerous waste permit application documentation to Ecology and the EPA in June 1992. Notice of Deficiency comments were received from Ecology on January 27, 1994. The Notice of Deficiency response table was submitted to Ecology on May 26, 1994. All Notice of Deficiency comments remain unresolved as Ecology has not responded to this submittal. The 224-T Transuranic Waste Storage and Assay Facility is scheduled to be incorporated into the HF RCRA Permit (DW Portion) in Modification E, calendar year 1999.

Prepared by: Westinghouse Hanford Company

Date: July 31,1996 Environmental Services 
The following information was prepared in response to requirements of DOE Order 5400.2A.

DOE Operations Office: Richland

DOE Facility: Hanford Site

Existing Permit ( ) Renewal ( ) New Permit (X)

Permit Type: RCRA

Permitting Agency: Washington State Department of Ecology

Permit Number: WA7890008967

Permitted Unit: $241-Z$ Treatment and Storage Tanks

Issuance Date:

Expiration Date:

Need for Headquarters' Action

(for permit renewals or new permits)
Yes ( ) No (X)

If yes, HQ Program Element

Brief Summary of Relevant Information (major permit conditions, status of compliance or unusual problems):

Part A, Form 3, dangerous waste permit application documentation for the 241-Z Treatment Tank originally was submitted to Ecology and the EPA in November 1987. Three revisions of the Part A, Form 3, dangerous waste permit application documentation have been submitted.

Tri-Party Agreement Milestone M-20-48 originally required submittal of the Part B dangerous waste permit application documentation for the $241-\mathrm{Z}$ Treatment and Storage Tanks to Ecology by May 31, 1996. Newly negotiated proposed Milestone M-20-48A replaces Milestone M-20-48 with a request to submit Part $\mathrm{B}$ dangerous waste permit application, closure plan, or preclosure plan documentation by December 31, 1996.

Prepared by: Westinghouse Hanford Company

Date: July 31, 1996 Environmental Services 
The following information was prepared in response to requirements of DOE Order 5400.2A.

DOE Operations Office: Richland

DOE Facility: Hanford Site

Existing Permit ( ) Renewal ( ) New Permit (X)

Permit Type: RCRA

Permitting Agency: Washington State Department of Ecology

Permit Number: WA7890008967

Permitted Unit: 242-A Evaporator

Issuance Date:

Expiration Date:

Need for Headquarters' Action (for permit renewals or new permits)

\section{Yes ( ) No (X)}

If yes, HQ Program Element

Brief Summary of Relevant Information (major permit conditions, status of compliance or unusual problems):

Part A, Form 3, dangerous waste permit application documentation for the 242-A Evaporator originally was submitted to Ecology and the EPA in September 1987. Six revisions of the Part A, Form 3, dangerous waste permit application documentation have been submitted.

Tri-Party Agreement Milestone M-20-17 was satisfied with the submittal of the Part B dangerous waste permit application documentation to Ecology and the EPA in June 1991. Workshops are ongoing with Ecology to finalize Revision 1 of the 242-A Evaporator Part B Dangerous Waste Permit Application documentation. The 242-A Evaporator is scheduled to be incorporated into the HF RCRA Permit (DW Portion) in Modification C, December 1997.

Prepared by: Westinghouse Hanford Company

Date: July 31,1996

Environmental Services 
The following information was prepared in response to requirements of DOE Order 5400.2A.

DOE Operations Office: Richland

DOE Facility: Hanford Site

Existing Permit (X) Renewal ( ) New Permit ( )

Permit Type: RCRA

Permitting Agency: Washington State Department of Ecology

Permit Number: WA7890008967

Permitted Unit: 305-B Storage Unit

Issuance Date: September 28, 1994 (Date Revision of the HF RCRA Pernit becanne effective, 30 days after permit issuance.)

Expiration Date: September 27, 2004

Need for Headquarters' Action

(for permit renewals or new permits)
Yes ( ) No (X)

If yes, HQ Program Element

Brief Summary of Relevant Information (major permit conditions, status of compliance or unusual problems):

Part A, Form 3, dangerous waste permit application documentation for the 305-B Storage Unit originally was submitted to Ecology and the EPA in May 1988. One revision of the Part A, Form 3, dangerous waste permit application documentation has been submitted.

Tri-Party Agreement Milestone M-20-08 was satisfied with the submittal of the Part B dangerous waste permit application documentation to Ecology and the EPA in January 1990. Revision 2 of the 305-B Storage Unit Part B dangerous waste permit application documentation was incorporated into Revision 0 of the HF RCRA Permit (DW Portion) that became effective on September 28, 1994. Several Class 1 modifications of the application documentation have been submitted quarterly since incorporation of the unit into the HF RCRA Permit (DW Portion).

Prepared by: Pacific Northwest National Laboratory

Date: July 31, 1996 Environmental Compliance 
The following information was prepared in response to requirements of DOE Order 5400.2A.

DOE Operations Office: Richland

DOE Facility: Hanford Site

$\begin{array}{lll}\text { Existing Permit ( ) } & \text { Renewal ( ) New Permit (X) }\end{array}$

Permit Type: RCRA

Permitting Agency: Washington State Department of Ecology

Permit Number: WA7890008967

Permitted Unit: 325 Hazardous Waste Treatment Units

Issuance Date:

Expiration Date:

Need for Headquarters' Action

(for permit renewals or new permits)
Yes ( ) No (X)

If yes, HQ Program Element

Brief Summary of Relevant Information (major permit conditions, status of compliance or unusual problems):

Part A, Form 3, dangerous waste permit application documentation for the 325 Hazardous Waste Treatment Units originally was submitted to Ecology and the EPA in May 1988. Three revisions of the Part A, Form 3, dangerous waste permit application documentation have been submitted.

Tri-Party Agreement Milestone M-20-20 was satisfied with the submittal of the Part B dangerous waste permit application documentation to Ecology and the EPA in June 1992. The 325 Shielded Analytical Laboratory activities that operated under the Physical/Chemical Treatment Test Facilities Part A, Form 3, were added to the 325 Hazardous Waste Treatment Units Part A, Form 3, on December 2, 1994. The Part B dangerous waste permit application documentation is being revised to reflect these changes. A draft Revision 1 of the 325 Hazardous Waste Treatment Units Part B Dangerous Waste Permit Application documentation was submitted in November 1995 to Ecology and the EPA, and workshops with Ecology to finalize Revision 1 are ongoing. The 325 Hazardous Waste Treatment Units is scheduled to be incorporated into the HF RCRA Permit (DW Portion) in Modification C, December 1997.

Prepared by: Pacific Northwest National Laboratory

Date: July 31, 1996 Environmental Compliance 
The following information was prepared in response to requirements of DOE Order 5400.2A.

DOE Operations Office: Richland

DOE Facility: Hanford Site

Existing Permit ( ) Renewal ( ) New Permit (X)

Permit Type: RCRA

Permitting Agency: Washington State Department of Ecology

Permit Number: WA7890008967

Permitted Unit: 600 Area Purgewater Storage and Treatment Facility

Issuance Date:

Expiration Date:

Need for Headquarters' Action (for permit renewals or new permits)
Yes ( ) No (X)

If yes, HQ Program Element

Brief Summary of Relevant Information (major permit conditions, status of compliance or unusual problems):

Part A, Form 3, dangerous waste permit application documentation for the 600 Area Purgewater Storage and Treatment Facility originally was submitted to Ecology and the EPA in February 1990. One revision of the Part A, Form 3, dangerous waste permit application documentation has been submitted.

Prepared by: Westinghouse Hanford Company

Date: July 31,1996

Environmental Services 
The following information was prepared in response to requirements of DOE Order $5400.2 \mathrm{~A}$.

DOE Operations Office: Richland

DOE Facility: Hanford Site

Existing Permit (X) Renewal ( ) New Permit ( )

Permit Type: RCRA

Permitting Agency: Washington State Department of Ecology

Permit Number: WA7890008967

Permitted Unit: 616 Nonradioactive Dangerous Waste Storage Facility

Issuance Date: September 28, 1994 (Date Revision 0 of the HF RCRA Permit became effective, 30 days after permit issuance),

Expiration Date: September 27, 2004

Need for Headquarters' Action

(for permit renewals or new permits)

Yes ( ) No (X)

If yes, HQ Program Element

Brief Summary of Relevant Information (major permit conditions, status of compliance or unusual problems):

Part A, Form 3, and Part B dangerous waste permit application documentation for the 616 Nonradioactive Dangerous Waste Storage Facility originally was submitted to Ecology and the EPA in November 1985. Five revisions of the Part A, Form 3, dangerous waste permit application documentation have been submitted.

Tri-Party Agreement Milestone M-20-02 was satisfied with the submittal of the Part B dangerous waste permit application documentation to Ecology and the EPA in July 1989. Revision 2 of the 616 Nonradioactive Dangerous Waste Storage Facility Part B dangerous waste permit application documentation was incorporated into Revision 0 of the HF RCRA Permit (DW Portion) that became effective on September 28, 1994. Several Class 1 modifications of the application documentation have been submitted quarterly and one Class III modification since incorporation of the unit into the HF RCRA Permit (DW Portion).

Prepared by: Westinghouse Hanford Company

Date: July 31,1996

Environmental Services 
The following information was prepared in response to requirements of DOE Order 5400.2A.

DOE Operations Office: Richland

DOE Facility: Hanford Site

Existing Permit ( ) Renewal ( ) New Permit (X)

Permit Type: RCRA

Permitting Agency: Washington State Department of Ecology

Permit Number: WA7890008967

Permitted Unit: Central Waste Complex

Issuance Date:

Expiration Date:

Need for Headquarters' Action

(for permit renewals or new permits)
Yes ( ) No ( $\mathrm{X}$ )

If yes, HQ Program Element

Brief Summary of Relevant Information (major permit conditions, status of compliance or unusual problems):

Part A, Form 3, dangerous waste permit application documentation for the Central Waste Complex originally was submitted to Ecology and the EPA in May 1988. Three revisions of the Part A, Form 3, dangerous waste permit application documentation have been submitted.

Tri-Party Agreement Milestone M-20-05 was satisfied with the submittal of the Part B dangerous waste permit application documentation to Ecology and the EPA in October 1991. A draft of Revision 1 of the Central Waste Complex Part B dangerous waste permit application documentation was submitted to Ecology and the EPA on December 31, 1994. Workshops are ongoing with Ecology to finalize Revision 1 of the Central Waste Complex Part B Dangerous Waste Permit Application documentation. The Central Waste Complex is scheduled to be incorporated into the HF RCRA Permit (DW Portion) in Modification D, calendar year 1998.

Prepared by: Westinghouse Hanford Company

Date: July 31,1996

Environmental Services 
The following information was prepared in response to requirements of DOE Order 5400.2A.

DOE Operations Office: Richland

DOE Facility: Hanford Site

Existing Permit ( ) Renewal ( ) New Permit (X)

Permit Type: RCRA

Permitting Agency: Washington State Department of Ecology

Permit Number: WA7890008967

Permitted Unit: Double-Shell Tank System

Issuance Date:

Expiration Date:

Need for Headquarters' Action

(for permit renewals or new permits)
Yes ( ) No (X)

If yes, HQ Program Element

Brief Summary of Relevant Information (major permit conditions, status of compliance or unusual problems):

Part A, Form 3, dangerous waste permit application documentation for the Double-Shell Tank System originally was submitted to Ecology and the EPA in September 1987. Seven revisions of the Part A, Form 3, dangerous waste permit application documentation have been submitted.

Tri-Party Agreement Milestone M-20-16 was satisfied with the submittal of the Part B dangerous waste permit application documentation to Ecology and the EPA in June 1991. The first Notice of Deficiency was received from Ecology on March 24, 1993. A Notice of Deficiency response table was prepared and submitted to Ecology and the EPA on July 13, 1993. A second set of Notice of Deficiency comments was received from Ecology on February 8, 1994. Workshops are ongoing with Ecology to finalize Revision 1 of the Double-Shell Tank System Part B Dangerous Waste Permit Application documentation. The Double-Shell Tank System is scheduled to be incorporated into the HF RCRA Permit (DW Portion) in Modification E, calendar year 1999. 
The following information was prepared in response to requirements of DOE Order 5400.2A.

DOE Operations Office: Richland

DOE Facility: Hanford Site

Existing Permit ( ) Renewal ( ) New Permit (X)

Permit Type: RCRA

Permitting Agency: Washington State Department of Ecology

Permit Number: WA7890008967

Permitted Unit: Grout Treatment Facility

Issuance Date:

Expiration Date:

Need for Headquarters' Action

(for permit renewals or new permits)
Yes ( ) No ( $\mathrm{X}$ )

If yes, HQ Program Element

Brief Summary of Relevant Information (major permit conditions, status of compliance or unusual problems):

Part A, Form 3, dangerous waste permit application documentation for the Grout Treatment Facility originally was submitted to Ecology and the EPA in September 1987. Four revisions of the Part A, Form 3, dangerous waste permit application documentation have been submitted.

Part B dangerous waste permit application documentation originally was submitted to Ecology and the EPA on November 23, 1988. Revision 2 of the Part B dangerous waste permit application documentation was submitted in July 1992. Per the Fourth Amendment of the Tri-Party Agreement, the Grout Treatment Facility has been placed in a standby mode. A letter notifying Ecology and the EPA that all work on the Grout Treatment Facility Part B dangerous waste permit application documentation is discontinued was submitted on April 26, 1994.

Prepared by: Westinghouse Hanford Company

Date: July 31, 1996 Environmental Services 
The following information was prepared in response to requirements of DOE Order 5400.2A.

DOE Operations Office: Richland

DOE Facility: Hanford Site

Existing Permit ( ) Renewal ( ) New Permit (X)

Permit Type: RCRA

Permitting Agency: Washington State Department of Ecology

Permit Number: WA7890008967

Permitted Unit: Hanford Waste Vitrification Plant

Issuance Date:

Expiration Date:

Need for Headquarters' Action

(for permit renewals or new permits)
Yes ( ) No ( $\mathrm{X}$ )

If yes, HQ Program Element

Brief Summary of Relevant Information (major permit conditions, status of compliance or unusual problems):

Part A, Form 3, dangerous waste permit application documentation for the Hanford Waste Vitrification Plant originally was submitted to Ecology and the EPA in May 1988. Four revisions of the Part A, Form 3, dangerous waste permit application documentation have been submitted.

Under milestones set in the original Tri-Party Agreement, construction of the Hanford Waste Vitrification Plant was to begin in 1992 and to be completed in 1998. Tri-Party Agreement Milestone M-20-01 was satisfied with the submittal of the Part $B$ dangerous waste permit application documentation to Ecology and the EPA in July 1989. Revision 2 of the Part B dangerous waste permit application documentation was submitted in October 1991. In April 1992, Ecology granted interim status for the construction of the Hanford Waste Vitrification Plant. The Hanford Waste Vitrification Plant, designed to meet the original Tri-Party Agreement milestones, is classified as a tank treatment and storage, a container storage, and a miscellaneous unit.

Per Amendment Four of the Tri-Party Agreement, construction of a high-level waste vitrification plant, such as the Hanford Waste Vitrification Plant, was delayed until 2002 to accommodate changes in waste management planning and prioritization. Hot startup of a high-level waste vitrification plant has been delayed until 2009 (per Tri-Party Agreement Milestone M-51-03).

Prepared by: Westinghouse Hanford Company

Date: July 31, 1996

Environmental Services 
The following information was prepared in response to requirements of DOE Order $5400.2 \mathrm{~A}$.

DOE Operations Office: Richland

DOE Facility: Hanford Site

Existing Permit ( ) Renewal ( ) New Permit (X)

Permit Type: RCRA

Permitting Agency: Washington State Department of Ecology

Permit Number: WA7890008967

Permitted Unit: Liquid Effluent Retention Facility

Issuance Date:

Expiration Date:

Need for Headquarters' Action

(for permit renewals or new permits)
Yes ( ) No (X)

If yes, HQ Program Element

Brief Summary of Relevant Information (major permit conditions, status of compliance or unusual problems):

Part A, Form 3, dangerous waste permit application documentation for the Liquid Effluent Retention Facility originally was submitted to Ecology and the EPA in February 1990. Four revisions of the Part A, Form 3, dangerous waste permit application documentation have been submitted.

Tri-Party Agreement Milestone M-20-47 was satisfied with the submittal of the Part B dangerous waste permit application documentation to Ecology and the EPA in June 1991. Workshops are ongoing with Ecology to finalize Revision 1 of the 200 Area Liquid Effluent Retention Facility Part B Dangerous Waste Permit Application documentation. The 200 Area Liquid Effluent Retention Facility is scheduled to be incorporated into the HF RCRA Permit (DW Portion) in Modification C, December 1997.

Prepared by: Westinghouse Hanford Company

Date: July 31,1996 Environmental Services 
The following information was prepared in response to requirements of DOE Order 5400.2A.

DOE Operations Office: Richland

DOE Facility: Hanford Site

Existing Permit ( ) Renewal ( ) New Permit (X)

Permit Type: RCRA

Permitting Agency: Washington State Department of Ecology

Permit Number: WA7890008967

Permitted Unit: Low-Level Burial Grounds

Issuance Date:

Expiration Date:

Need for Headquarters' Action

(for permit renewals or new permits)
Yes ( ) No ( $\mathrm{X}$ )

If yes, HQ Program Element

Brief Summary of Relevant Information (major permit conditions, status of compliance or unusual problems):

Part A, Form 3, and Part B dangerous waste permit application documentation for the Low-Level Burial Grounds originally was submitted to Ecology and the EPA in October 1985. Seven revisions of the Part A, Form 3, dangerous waste permit application documentation have been submitted.

Tri-Party Agreement Milestone M-20-06 was satisfied with the submittal of the Part B dangerous waste permit application documentation to Ecology and the EPA in December 1989. Workshops are ongoing with Ecology to finalize Revision 1 of the Low-Level Burial Grounds Part B Dangerous Waste Permit Application documentation. The Low-Level Burial Grounds is scheduled to be incorporated into the HF RCRA Permit (DW Portion) in Modification C, December 1997.

Prepared by: Westinghouse Hanford Company

Date: July 31,1996

Environmental Services 
The following information was prepared in response to requirements of DOE Order 5400.2A.

DOE Operations Office: Richland

DOE Facility: Hanford Site

Existing Permit ( ) Renewal ( ) New Permit (X)

Permit Type: RCRA

Permitting Agency: Washington State Department of Ecology

Permit Number: WA7890008967

Permitted Unit: Plutonium Finishing Plant Storage Vaults

Issuance Date:

Expiration Date:

Need for Headquarters' Action

(for permit renewals or new permits)

\section{Yes ( ) No (X)}

If yes, HQ Program Element

Brief Summary of Relevant Information (major permit conditions, status of compliance or unusual problems):

Residue items containing special nuclear materials at the Plutonium Finishing Plant are stored and processed as valuable materials in accordance with DOE orders per the Atomic Energy Act of 1954. Recent guidance from DOE-Headquarters states that these materials are not to be regulated by the RCRA before stabilization. Facility stabilization activities are proceeding in accordance with Tri-Party Agreement milestones.

Prepared by: Westinghouse Hanford Company

Date: July 31, 1996 Environmental Services 
The following information was prepared in response to requirements of DOE Order $5400.2 \mathrm{~A}$.

DOE Operations Office: Richland

DOE Facility: Hanford Site

Existing Permit ( ) Renewal ( ) New Permit (X)

Permit Type: RCRA

Permitting Agency: Washington State Department of Ecology

Permit Number: WA7890008967

Permitted Unit: PUREX Storage Tunneis

Issuance Date:

Expiration Date:

Need for Headquarters' Action

(for permit renewals or new permits)
Yes ( ) No (X)

If yes, HQ Program Element

Brief Summary of Relevant Information (major permit conditions, status of compliance or unusual problems):

Part A, Form 3, dangerous waste permit application documentation for the PUREX Storage Tunnels originally was submitted to Ecology and the EPA in November 1987. Four revisions of the Part A, Form 3, dangerous waste permit application documentation have been submitted. The PUREX Storage Tunnels store material from the PUREX Plant and other onsite sources.

Tri-Party Agreement Milestone M-20-11 was satisfied with the submittal of the Part B dangerous waste permit application documentation to Ecology and the EPA in September 1990. Revision 3 of the PUREX Storage Tunnels Part B dangerous waste permit application documentation was submitted to Ecology on July 26, 1996. The PUREX Storage Tunnels are scheduled to be incorporated into Revision 3 of the HF RCRA Permit (DW Portion) scheduled to become effective in December 1996.

Prepared by: Westinghouse Hanford Company

Date: July 31, 1996

Environmental Services 
The following information was prepared in response to requirements of DOE Order $5400.2 \mathrm{~A}$.

DOE Operations Office: Richland

DOE Facility: Hanford Site

Existing Permit ( ) Renewal ( ) New Permit (X)

Permit Type: RCRA

Permitting Agency: Washington State Department of Ecology

Permit Number: WA7890008967

Permitted Unit: Socium Storage Facility and Sodium Reaction Facility

Issuance Date:

Expiration Date:

Need for Headquarters' Action

(for permit renewais or new permits)
Yes ( ) No (X)

If yes, HQ Program Element

Brief Summary of Relevant Information (major permit conditions, status of compliance or unusual problems):

Part A, Form 3, dangerous waste permit application documentation for the Sodium Storage Facility and Sodium Reaction Facility originally was submitted to Ecology and the EPA on May 1, 1995. No revisions of the Part A, Form 3, dangerous waste permit application documentation have been submitted.

Shutdown of the Fast Flux Test Facility began in 1993. A study to determine if the sodium removed from the Fast Flux Test Facility has any beneficial use is to be completed in 1998. In the event that a beneficial use cannot be found, the Sodium Storage Facility and Sodium Reaction Facility will be relied upon to process the sodium for disposal. The unit is being designed and constructed as a RCRA compliant unit, in the event that the Fast Flux Test Facility sodium is determined to be a waste. Construction of the Sodium Storage Facility under interim status began in June 1995. 
The following information was prepared in response to requirements of DOE Order $5400.2 \mathrm{~A}$.

DOE Operations Office: Richland

DOE Facility: Hanford Site

Existing Permit ( ) Renewal ( ) New Permit (X)

Permit Type: RCRA

Permitting Agency: Washington State Department of Ecology

Permit Number: WA7890008967

Permitted Unit: T Plant Complex

Issuance Date:

Expiration Date:

Need for Headquarters' Action

(for permit renewals or new permits)
Yes ( ) No ( $\mathrm{X}$ )

If yes, HQ Program Element

Brief Summary of Relevant Information (major permit conditions, status of compliance or unusual problems):

Part A, Form 3, dangerous waste permit application documentation for the T Plant Complex originally was submitted to Ecology and the EPA in November 1987. Five revisions of the Part A, Form 3, dangerous waste permit application documentation have been submitted.

Tri-Party Agreement Milestone M-20-51 was satisfied with the submittal of the Part B dangerous waste permit application documentation to Ecology and the EPA in December 1995. The T Plant Complex is scheduled to be incorporated into the HF RCRA Permit (DW Portion) in Modification G, calendar year 2001.

Prepared by: Westinghouse Hanford Company

Date: July 31, 1996

Environmental Services 
The following information was prepared in response to requirements of DOE Order 5400.2A.

DOE Operations Office: Richland

DOE Facility: Hanford Site

Existing Permit ( ) Renewal ( ) New Permit (X)

Permit Type: RCRA

Permitting Agency: Washington State Department of Ecology

Permit Number: WA7890008967

Permitted Unit: Waste Receiving and Processing

Issuance Date:

Expiration Date:

Need for Headquarters' Action

(for permit renewals or new permits)
Yes ( ) No ( $\mathrm{X}$ )

If yes, HQ Program Element

Brief Summary of Relevant Information (major permit conditions, status of compliance or unusual problems):

Part A, Form 3, dangerous waste permit application documentation for the Waste Receiving and Processing originally was submitted to Ecology and the EPA on January 25, 1995. No revisions of the Part A, Form 3, dangerous waste permit application documentation have been submitted.

Tri-Party Agreement Milestone M-20-12 was satisfied with the submittal of the Part B dangerous waste permit application documentation to Ecology and the EPA in October 1991. A draft of Revision 1 of the Waste Receiving and Processing Part B Dangerous Waste Permit Application documentation was submitted to Ecology and the EPA on December 31, 1994. Workshops are ongoing with Ecology to finalize Revision 1 of the Waste Receiving and Processing Part B Dangerous Waste Permit Application documentation. Waste Receiving and Processing is scheduled to be incorporated into the HF RCRA Permit (DW Portion) in Modification D, calendar year 1998.

Prepared by: Westinghouse Hanford Company

Date: July 31,1996 Environmental Services 


\section{RESOURCE CONSERVATION AND RECOVERY ACT}

PROCEDURAL CLOSURE PERMITTING 
DOE/RL-96-63, Rev. 0

$10 / 96$

This page intentionally left blank. 
The following information was prepared in response to requirements of DOE Order 5400.2A.

DOE Operations Office: Richland

DOE Facility: Hanford Site

Existing Permit ( ) Renewal ( ) New Permit (X)

Permit Type: RCRA Procedural Closure

Permitting Agency: Washington State Department of Ecology

Permit Number: WA7890008967

Permitted Unit: 221-T Containment Systems Test Facility

Issuance Date:

Expiration Date:

Need for Headquarters' Action

(for permit renewals or new permits)
Yes ( ) No (X)

If yes, HQ Program Element

Brief Summary of Relevant Information (major permit conditions, status of compliance or unusual problems):

Part A, Form 3, and Part B dangerous waste permit application documentation for the 221-T Containment Systems Test Facility originally was submitted to Ecology and the EPA in November 1985. Two revisions of the Part A, Form 3, dangerous waste permit application documentation have been submitted.

This unit was included in the withdrawal request package submitted to Ecology and the EPA on June 22, 1989, in fulfillment of Tri-Party Agreement Milestone M-20-45. Ecology reviewed this submittal and requested additional information for this unit. In December 1989, additional information was submitted to Ecology in support of the withdrawal request. Ecology has taken no further action on this withdrawal request. 
The following information was prepared in response to requirements of DOE Order 5400.2A.

DOE Operations Office: Richland

DOE Facility: Hanford Site

Existing Permit ( ) $\quad$ Renewal ( ) New Permit (X)

Permit Type: RCRA Procedural Closure

Permitting Agency: Washington State Department of Ecology

Permit Number: WA7890008967

Permitted Unit: 324 Pilot Plant

Issuance Date:

Expiration Date:

Need for Headquarters' Action

(for permit renewals or new permits)
Yes ( ) No (X)

If yes, HQ Program Element

Brief Summary of Relevant Information (major permit conditions, status of compliance or unusual problems):

Part A, Form 3, dangerous waste permit application documentation for the 324 Pilot Plant originally was submitted to Ecology and the EPA in November 1985. Three revisions of the Part A, Form 3, dangerous waste permit application documentation have been submitted.

This unit was included in the withdrawal request package submitted to Ecology and the EPA on June 22, 1989, in fulfillment of Tri-Party Agreement Milestone M-20-45. Ecology reviewed this submittal and requested additional information for this unit. In December 1989, additional information was submitted to Ecology in support of the withdrawal request. Ecology has taken no further action on this withdrawal request.

Prepared by: Pacific Northwest National Laboratory

Date: July 31,1996 Environmental Compliance 
The following information was prepared in response to requirements of DOE Order 5400.2A.

DOE Operations Office: Richland

DOE Facility: Hanford Site

Existing Permit ( ) Renewal ( ) New Permit (X)

Permit Type: RCRA Procedural Closure

Permitting Agency: Washington State Department of Ecology

Permit Number: WA7890008967

Permitted Unit: 332 Storage Facility

Issuance Date:

Expiration Date:

Need for Headquarters' Action

(for permit renewals or new permits)
Yes ( ) No (X)

If yes, HQ Program Element

Brief Summary of Relevant Information (major permit conditions, status of compliance or unusual problems):

Part A, Form 3, dangerous waste permit application documentation for the 332 Storage Facility originally was submitted to Ecology and the EPA in May 1988. No revisions of the Part A, Form 3, dangerous waste permit application documentation have been submitted.

This unit was included in the withdrawal request package submitted to Ecology and the EPA on June 22, 1989, in fulfillment of Tri-Party Agreement Milestone M-20-45. Ecology reviewed this submittal and requested additional information for this unit. In December 1989, additional information was submitted to Ecology in support of the withdrawal request. Ecology has taken no further action on this withdrawal request.

Prepared by: Pacific Northwest National Laboratory

Date: July 31,1996

Environmental Compliance 
The following information was prepared in response to requirements of DOE Order 5400.2A.

DOE Operations Office: Richland

DOE Facility: Hanford Site

Existing Permit ( ) Renewal ( ) New Permit (X)

Permit Type: RCRA Procedural Closure

Permitting Agency: Washington State Department of Ecology

Permit Number: WA7890008967

Permitted Unit: 437 Maintenance and Storage Facility

Issuance Date:

Expiration Date:

Need for Headquarters' Action

(for permit renewals or new permits)
Yes ( ) No (X)

If yes, HQ Program Element

Brief Summary of Relevant Information (major permit conditions, status of compliance or unusual problems):

Part A, Form 3, and Part B dangerous waste permit application documentation for the Maintenance and Storage Facility originally was submitted to Ecology and the EPA in November 1985. Two revisions of the Part A, Form 3, dangerous waste permit application documentation have been submitted.

Tri-Party Agreement Milestone M-20-29 required submittal of revised Part B dangerous waste permit application documentation to Ecology and the EPA by November 30, 1993. Tri-Party Agreement change request M-20-92-6 was submitted to Ecology and the EPA in September 1992, which deferred the milestone. Regulator approval of the change request was received in October 1992. The decision to shutdown the Fast Flux Test Facility was made in 1994. Procedural closure in accordance with Section 6.3.3 of the Tri-Party Agreement is being pursued for this unit.

Prepared by: Westinghouse Hanford Company

Date: July 31, 1996 Environmental Services 
The following information was prepared in response to requirements of DOE Order 5400.2A.

DOE Operations Office: Richland

DOE Facility: Hanford Site

Existing Permit ( ) Renewal ( ) New Permit (X)

Permit Type: RCRA Procedural Closure

Permitting Agency: Washington State Department of Ecology

Permit Number: WA7890008967

Permitted Unit: 1706-KE Waste Treatment System

Issuance Date:

Expiration Date:

Need for Headquarters' Action

(for permit renewals or new permits)
Yes ( ) No (X)

If yes, HQ Program Element

Brief Summary of Relevant Information (major permit conditions, status of compliance or unusual problems):

Part A, Form 3, dangerous waste permit application documentation for the 1706-KE Waste Treatment System originally was submitted to Ecology in August 1986. Two revisions of the Part A, Form 3, dangerous waste permit application documentation have been submitted. Part B dangerous waste permit application documentation was submitted to Ecology and the EPA in April 1987.

This unit was included in the withdrawal request package submitted to Ecology and the EPA on June 22, 1989, in fulfillment of Tri-Party Agreement Milestone M-20-45. Ecology reviewed this submittal and requested additional information for this unit. In December 1989, additional information was submitted to Ecology in support of the withdrawal request. Ecology has taken no further action on this withdrawal request.

Prepared by: Westinghouse Hanford Company

Date: July 31,1996

Environmental Services 
The following information was prepared in response to requirements of DOE Order $5400.2 \mathrm{~A}$.

DOE Operations Office: Richland

DOE Facility: Hanford Site

Existing Permit ( ) Renewal ( ) New Permit (X)

Permit Type: RCRA Procedural Closure

Permitting Agency: Washington State Department of Ecology

Permit Number: WA7890008967

Permitted Unit: 2727-WA Sodium Reactor Experiment Sodium Storage Building

Issuance Date:

Expiration Date:

Need for Headquarters' Action

(for permit renewals or new permits)
Yes ( ) No (X)

If yes, HQ Program Element

Brief Summary of Relevant Information (major permit conditions, status of compliance or unusual problems):

Part A, Form 3, dangerous waste permit application documentation for the 2727-WA Sodium Reactor Experiment Sodium Storage Building originally was submitted to Ecology and the EPA in November 1987. No revisions of the Part A, Form 3, dangerous waste permit application documentation have been submitted.

This unit was included in the withdrawal request package submitted to Ecology and the EPA on June 22, 1989, in fulfillment of Tri-Party Agreement Milestone M-20-45. Ecology reviewed this submittal and requested additional information for this unit. In December 1989, additional information was submitted to Ecology in support of the withdrawal request. Ecology has taken no further action on this withdrawal request.

Prepared by: Westinghouse Hanford Company

Date: July 31, 1996 Environmental Services 
The following information was prepared in response to requirements of DOE Order $5400.2 \mathrm{~A}$.

DOE Operations Office: Richland

DOE Facility: Hanford Site

Existing Permit ( ) Renewal ( ) New Permit ( X)

Permit Type: RCRA Procedural Closure

Permitting Agency: Washington State Department of Ecology

Permit Number: WA7890008967

Permitted Unit: Biological Treatment Test Facilities

Issuance Date:

Expiration Date:

Need for Headquarters' Action

(for permit renewals or new permits)
Yes ( ) No (X)

If yes, HQ Program Element

Brief Summary of Relevant Information (major permit conditions, status of compliance or unusual problems):

Part A, Form 3, dangerous waste permit application documentation for the Biological Treatment Test Facilities originally was submitted to Ecology and the EPA in May 1988. No revisions of the Part A, Form 3, dangerous waste permit application documentation have been submitted.

Tri-Party Agreement Milestone M-20-44 required submittal of the Part B dangerous waste permit application documentation to Ecology and the EPA by December 31, 1995. Procedural closure documentation in accordance with Section 6.3.3 of the Tri-Party Agreement was submitted in December 1995 to fulfill Milestone M-20-44. On July 11, 1996, Ecology notified DOE-RL that the documentation is complete and that Ecology will pursue the administrative process to terminate interim status. Once the administrative process is complete, this unit will be closed.

Prepared by: Pacific Northwest National Laboratory

Date: July 31,1996

$$
\text { Environmental Compliance }
$$


The following information was prepared in response to requirements of DOE Order $5400.2 \mathrm{~A}$.

DOE Operations Office: Richland

DOE Facility: Hanford Site

Existing Permit ( ) Renewal ( ) New Permit (X)

Permit Type: RCRA Procedural Closure

Permitting Agency: Washington State Department of Ecology

Permit Number: WA7890008967

Permitted Unit: Physical and Chemical Treatment Test Facilities

Issuance Date:

Expiration Date:

Need for Headquarters' Action

(for permit renewals or new permits)
Yes ( ) No ( $\mathrm{X}$ )

If yes, HQ Program Element

Brief Summary of Relevant Information (major permit conditions, status of compliance or unusual problems):

Part A, Form 3, dangerous waste permit application documentation for the Physical and Chemical Treatment Test Facilities originally was submitted to Ecology and the EPA in May 1988. One revision of the Part A, Form 3, dangerous waste permit application documentation has been submitted.

Tri-Party Agreement Milestone M-20-43A required submittal of a closure plan for this unit by September 30, 1995. Procedural closure documentation in accordance with Section 6.3 .3 of the Tri-Party Agreement was submitted in September 1995 to fulfill Milestone M-20-43A. On January 25, 1996, Ecology notified DOE-RL that the documentation was complete and that Ecology would pursue the administrative process to terminate interim status. On May 13, 1996, Ecology completed the administrative process. The Part A, Form 3, dangerous waste permit application documentation was stamped with "closed as of May 13, 1995" to indicate that procedural closure has occurred.

Prepared by: Pacific Northwest National Laboratory

Date: July 31, 1996 Environmental Compliance 
The following information was prepared in response to requirements of DOE Order 5400.2A.

DOE Operations Office: Richland

DOE Facility: Hanford Site

Existing Permit ( ) Renewal ( ) New Permit (X)

Permit Type: RCRA Procedural Closure

Permitting Agency: Washington State Department of Ecology

Permit Number: WA7890008967

Permitted Unit: Thermal Treatment Test Facilities

Issuance Date:

Expiration Date:

Need for Headquarters' Action

(for permit renewals or new permits)
Yes ( ) No ( X)

If yes, $\mathrm{HQ}$ Program Element

Brief Summary of Relevant Information (major permit conditions, status of compliance or unusual problems):

Part A, Form 3, dangerous waste permit application documentation for the Thermal Treatment Test Facilities originally was submitted to Ecology and the EPA in May 1988. No revisions of the Part A, Form 3, dangerous waste permit application documentation have been submitted.

Tri-Party Agreement Milestone M-20-42A requires submittal of a closure plan for this unit by September 30, 1995. Procedural closure documentation in accordance with Section 6.3 .3 of the Tri-Party Agreement was submitted in September 1995 to fulfill Milestone M-20-42A. On January 25, 1996, Ecology notified DOE-RL that the documentation was complete and that Ecology would pursue the administrative process to terminate interim status. On May 13, 1996, Ecology completed the administrative process. The Part A, Form 3, dangerous waste permit application documentation was stamped with "closed as of May 13, 1995" to indicate that procedural closure has occurred.

Prepared by: Pacific Northwest National Laboratory

Date: July 31,1996

Environmental Compliance 
DOE/RL-96-63, Rev. 0

This page intentionally left blank. 
DOE/RL-96-63, Rev. 0

$10 / 96$

RESOURCE CONSERVATION AND RECOVERY ACT

RESEARCH, DEVELOPMENT, AND DEMONSTRATION PERMITTING 
DOE/RL-96-63, Rev. 0

$10 / 96$

This page intentionally left blank. 
The following information was prepared in response to requirements of DOE Order 5400.2A.

DOE Operations Office: Richland

DOE Facility: Hanford Site

Existing Permit ( $\mathrm{X}$ ) Renewal ( ) New Permit ( )

Permit Type: RCRA

Permitting Agency: U.S. Environmental Protection Agency, Region 10

Washington State Department of Ecology

Permit Number: WA7890008967

Permitted Unit: Waste Water Pilot Plant

Issuance Date: May 4, 1994

Expiration Date: June 6, 1998

Need for Headquarters' Action

(for permit renewals or new permits)

Yes ( ) No (X)

If yes, HQ Program Element

Brief Summary of Relevant Information (major permit conditions, status of compliance or unusual problems):

Revision 1 of RD\&D permit application documentation for the Waste Water Pilot Plant was submitted to Ecology and the EPA in April 1992. Revision 0 of the Waste Water Pilot Plant RD\&D Permit was issued on May 4, 1994, and became effective on June 6, 1994.

Prepared by: Westinghouse Hanford Company

Date: July 31, 1996

Environmental Services 
This page intentionally left blank. 
DOE/RL-96-63, Rev. 0

$10 / 96$

TOXIC SUBSTANCES CONTROL ACT PERMITTING 
DOE/RL-96-63, Rev. 0

$10 / 96$

This page intentionally left blank. 
The following information was prepared in response to requirements of DOE Order 5400.2A.

DOE Operations Office: Richland

DOE Facility: Hanford Site

Existing Permit ( ) Renewal ( ) New Permit (X)

Permit Type: TSCA RD\&D Permit

Permitting Agency: U.S. Environmental Protection Agency, Region 10

Permit Number: TBD

Permitted Unit: Graphite Electrode DC Arc Plasma Furnace, 324 Building

Issuance Date:

Expiration Date:

Need for Headquarters' Action

(for permit renewals or new permits)
Yes ( ) No (X)

If yes, HQ Program Element

Brief Summary of Relevant Information (major permit conditions, status of compliance or unusual problems):

This permit application is in preparation for the development and testing of a sealed graphite electrode DC arc plasma furnace. The furnace will be tested to evaluate the efficiency of treating waste contaminated with transuranic isotopes and polychlorinated biphenyl waste. The permit application is being prepared for review in the Fall of 1996. Tests using actual waste feedstock are tentatively scheduled for the Fall of 1997.

Prepared by: Pacific Northwest National Laboratory

Date: July 31, 1996

Environmental Compliance 
The following information was prepared in response to requirements of DOE Order 5400.2A.

DOE Operations Office: Richland

DOE Facility: Hanford Site

Existing Permit ( ) Renewal ( ) New Permit (X)

Permit Type: TSCA

Permitting Agency: U.S. Environmental Protection Agency, Region 10

Permit Number:

Permitted Unit: Low-Level Burial Grounds

Issuance Date:

Expiration Date:

Need for Headquarters' Action

(for permit renewals or new permits)

Yes ( ) No (X)

If yes, HQ Program Element

Brief Summary of Relevant Information (major permit conditions, status of compliance or unusual problems):

Revision 2 of the Request for Interim Approval to Operate Trench 94 of the 218-E-12B Burial Ground as a Chemical Waste Landfill for Disposal of Polychlorinated Biphenyl Waste in Submarine Reactor Compartments was submitted to the EPA on June 10,1994. This revision sought interim approval to operate a Toxic Substances Control Act chemical waste landfill for the disposal of polychlorinated biphenyl waste.

The EPA has tentatively approved the chemical waste landfill request pending issuance of the Low-Level Burial Grounds Part B Dangerous Waste Permit Application documentation. The EPA determined that DOE-RL's documentation of compliance with WAC 173-303, which is equivalent to or more stringent than Toxic Substances Control Act chemical requirements, would be sufficient to show compliance with the Toxic Substances Control Act requirements.

Prepared by: Westinghouse Hanford Company

Date: July 31,1996 Environmental Services 
DOE/RL-96-63, Rev. 0

$10 / 96$

\section{RESOURCE CONSERVATION AND RECOVERY ACT}

\section{CLOSURE PLANS}


DOE/RL-96-63, Rev. 0

$10 / 96$

This page intentionally left blank. 
The following information was prepared in response to requirements of DOE Order $5400.2 \mathrm{~A}$.

DOE Operations Office: Richland

DOE Facility: Hanford Site

Existing Permit ( ) Renewal ( ) New Permit (X)

Permit Type: RCRA Closure Plan

Permitting Agency: Washington State Department of Ecology

Permit Number: WA7890008967

Permitted Unit: 100-D Ponds

Issuance Date:

Expiration Date:

Need for Headquarters' Action

(for permit renewals or new permits)
Yes ( ) No (X)

If yes, HQ Program Element

Brief Summary of Relevant Information (major permit conditions, status of compliance or unusual problems):

Part A, Form 3, dangerous waste permit application documentation for the 100-D Ponds originally was submitted to Ecology and the EPA in August 1986. Four revisions of the Part A, Form 3, dangerous waste permit application documentation have been submitted.

Tri-Party Agreement Milestone $\mathrm{M}-20-40$ was satisfied with the submittal of the 100-D Ponds Closure Plan to Ecology and the EPA on February 26, 1993. This closure plan is under review by the regulators. The 100-D Ponds is scheduled to be incorporated into the HF RCRA Permit (DW Portion) in Modification D, calendar year 1998.

Unit characterization was performed in January 1995. A data quality objectives process was carried out between December 1995 and January 1996. This process concluded that sampling was adequate to characterize the surface soils at the unit. Excavation of contaminated surface soils is anticipated to occur in the last quarter of fiscal year 1996. Ecology has stated that soils at depth may require further sampling to determine if this unit can close under a clean closure option.

Prepared by: Bechtel Hanford, Inc.

Date: July 31,1996

Regulatory Support 
The following information was prepared in response to requirements of DOE Order 5400.2A.

DOE Operations Office: Richland

DOE Facility: Hanford Site

Existing Permit ( ) Renewal ( ) New Permit ( X)

Permit Type: RCRA Closure Plan

Permitting Agency: Washington State Department of Ecology

Permit Number: WA7890008967

Permitted Unit: 105-DR Large Sodium Fire Facility

Issuance Date: September 28, 1995 (Date Revision 2 of the HF RCRA Permit became effective, 30 days after permit issuance.)

Expiration Date: September 27, 2004

Need for Headquarters' Action

(for permit renewals or new permits)
Yes ( ) No (X)

If yes, HQ Program Element

Brief Summary of Relevant Information (major permit conditions, status of compliance or unusual problems):

Part A, Form 3, and Part B dangerous waste permit application documentation for the 105-DR Large Sodium Fire Facility originally was submitted to Ecology and the EPA in November 1985. Subsequently, a decision was made to close this TSD unit. Two revisions of the Part A, Form 3, dangerous waste permit application documentation have been submitted.

Tri-Party Agreement Milestone M-20-41 was satisfied with the submittal of the 105-DR Large Sodium Fire Facility Closure Plan to Ecology and the EPA in September 1990. Revision 2 of the closure plan was submitted to Ecology and the EPA in April 1995. The 105-DR Large Sodium Fire Facility Closure Plan was incorporated into Revision 2 of the HF RCRA Permit (DW Portion) that became effective on September 28, 1995.

Closure activities began in July 1995 and were completed in March 1996. Closure certification was received from Ecology on June 16, 1996. The unit will be partially clean closed. The Part A, Form 3 , is being revised to show the clean closed areas of the unit. The areas that were not cleaned closed will be remediated during decommissioning of the 105-DR reactor building and associated systems.

Prepared by: Westinghouse Hanford Company

Date: July 31,1996 Environmental Services 
The following information was prepared in response to requirements of DOE Order 5400.2A.

DOE Operations Office: Richland

DOE Facility: Hanford Site

Existing Permit (X) Renewal ( ) New Permit ( )

Permit Type: RCRA Closure Plan

Permitting Agency: Washington State Department of Ecology

Permit Number: WA7890008967

Permitted Unit: $183-\mathrm{H}$ Solar Evaporation Basins

Issuance Date: September 28, 1994 (Date Revision 0 of ine HF RCRA Pemmit became effective, 30 days after permit issuance.)

Expiration Date: September 27, 2004

Need for Headquarters' Action

(for permit renewals or new permits)

$$
\begin{aligned}
& \text { Yes ( ) No (X) } \\
& \text { If yes, HQ Program Element }
\end{aligned}
$$

Brief Summary of Relevant Information (major permit conditions, status of compliance or unusual problems):

Part A, Form 3, dangerous waste permit application documentation for the 183-H Solar Evaporation Basins originally was submitted to Ecology and the EPA in November 1985. Four revisions of the Part A, Form 3, dangerous waste permit application documentation have been submitted.

The 183-H Solar Evaporation Basins Closure Plan was submitted to Ecology and the EPA in June 1988. Revision 2 of the 183-H Solar Evaporation Basins Closure Plan was incorporated into Revision 0 of the HF RCRA Permit (DW Portion) that became effective on September 28, 1994. This unit was certified as a closed unit on July 26, 1996. Postclosure care will be required under a modified closure option.

Prepared by: Bechtel Hanford, Inc.

Date: July 31, 1996

Regulatory Support 
The following information was prepared in response to requirements of DOE Order 5400.2A.

DOE Operations Office: Richland

DOE Facility: Hanford Site

Existing Permit (X) Renewal ( ) New Permit ( )

Permit Type: RCRA Closure Plan

Permitting Agency: Washington State Department of Ecology

Permit Number: WA7890008967

Permitted Unit: 200 West Area Ash Pit Demolition Site

Issuance Date: May 29, 1995 (Date Revsinn I of the HF RCRA Permut became effective, 30 days after permit issuance.)

Expiration Date: September 27, 2004

Need for Headquarters' Action

(for permit renewals or new permits)

Yes ( ) No (X)

If yes, HQ Program Element

Brief Summary of Relevant Information (major permit conditions, status of compliance or unusual problems):

Part A, Form 3, and Part B dangerous waste permit application documentation for the 200 West Area Ash Pit Demolition Site originally was submitted to Ecology and the EPA in November 1985. Subsequently, a decision was made to close this TSD unit. Four revisions of the Part A, Form 3, dangerous waste permit application documentation have been submitted.

Tri-Party Agreement Milestone M-20-26 was satisfied with the submittal of the 200 West Area Ash Pit Demolition Site Closure Plan to Ecology and the EPA in November 1992. Revision 1 of the closure plan was submitted to Ecology and the EPA in October 1994. Revision 1 of the 200 West Area Ash Pit Demolition Site Closure Plan was incorporated into Revision 1 of the HF RCRA Permit (DW Portion) that became effective on May 29, 1995. Closure certification was submitted to Ecology on September 22, 1995. On October 26, 1995, Ecology approved the clean closure certification. The Part A, Form 3, dangerous waste permit application documentation was stamped with "closed as of October 26, 1995" and submitted to Ecology on November 28, 1995.

Prepared by: Westinghouse Hanford Company

Date: July 31,1996

Environmental Services 
The following information was prepared in response to requirements of DOE Order 5400.2A.

DOE Operations Office: Richland

DOE Facility: Hanford Site

Existing Permit ( ) Renewal ( ) New Permit (X)

Permit Type: RCRA Closure Plan

Permitting Agency: Washington State Department of Ecology

U. S. Environmental Protection Agency, Region 10

Permit Number: WA7890008967

Permitted Unit: 207-A South Retention Basin

Issuance Date:

Expiration Date:

Need for Headquarters' Action

(for permit renewals or new permits)
Yes ( ) No (X)

If yes, HQ Program Element

Brief Summary of Relevant Information (major permit conditions, status of compliance or unusual problems):

Part A, Form 3, dangerous waste permit application documentation for the 207-A South Retention Basin originally was submitted to Ecology and the EPA in February 1990. One revision of the Part A, Form 3, dangerous waste permit application documentation has been submitted.

A Tri-Party Agreement change request was prepared to coordinate the closure plan with the past-practice documentation for the 200-PO-5 Operable Unit. The submittal date for this documentation is October 31, 1999, to Ecology and the EPA.

Prepared by: Westinghouse Hanford Company

Date: July 31, 1996

Environmental Services 
The following information was prepared in response to requirements of DOE Order 5400.2A.

DOE Operations Office: Richland

DOE Facility: Hanford Site

Existing Permit (X) Renewal ( ; $\quad$ New Permit ( )

Permit Type: RCRA Closure Plan

Permitting Agency: Washington State Department of Ecology

Permit Number: WA7890008967

Permitted Unit: 216-B-3 Expansion Ponds

Issuance Date: May 29, 1995 (Date Revision 1 of the HF RCRA Permit became effective, 30 days after permit issuance.)

Expiration Date: September 27, 2004

Need for Headquarters' Action

(for permit renewals or new permits)

\author{
Yes ( ) No ( X) \\ If yes, HQ Program Element
}

Brief Summary of Relevant Information (major permit conditions, status of compliance or unusual problems):

Originally the 216-B-3 Expansion Ponds were included with the 216-B-3 Pond Main Lobe, in a single Part A, Form 3, dangerous waste permit application documentation. In December 1993, the 216-B-3 Pond System Part A, Form 3, dangerous waste permit application documentation was separated into two Part A, Form 3s: one for the 216-B-3 Expansion Ponds and one for the 216-B-3 Main Pond and 216-B-3-3 Ditch. Part A, Form 3, dangerous waste permit application and closure plan documentation for the 216-B-3 Expansion Ponds were submitted to Ecology and the EPA on December 16, 1993. No revisions of the Part A, Form 3, dangerous waste permit application documentation have been submitted.

Revision 2 of the 216-B-3 Expansion Ponds Closure Plan was incorporated into Revision 1 of the HF RCRA Permit (DW Portion) that became effective on May 29, 1995. Closure certification was submitted to Ecology on June 14, 1995. On June 27, 1995, Ecology approved the clean closure certification. The Part A, Form 3, dangerous waste permit application documentation was stamped with "closed as of June 27, 1995" and submitted to Ecology on July 31, 1995.

Prepared by: Westinghouse Hanford Company

Date: July 31,1996

Environmental Services 
The following information was prepared in response to requirements of DOE Order 5400.2A.

DOE Operations Office: Richland

DOE Facility: Hanford Site

Existing Permit ( ) Renewal ( ) New Permit (X)

Permit Type: RCRA Closure Plan

Permitting Agency: Washington State Department of Ecology

U.S. Environmental Protection Agency, Region 10

Permit Number: WA7890008967

Permitted Unit: 216-B-63 Trench

Issuance Date:

Expiration Date:

Need for Headquarters' Action

(for permit renewals or new permits)
Yes ( ) No (X)

If yes, HQ Program Element

Brief Summary of Relevant Information (major permit conditions, status of compliance or unusual problems):

Part A, Form 3, dangerous waste permit application documentation for the 216-B-63 Trench originally was submitted to Ecology and the EPA in August 1986. Two revisions of the Part A, Form 3, dangerous waste permit application documentation have been submitted.

The 216-B-63 Trench Closure Plan was submitted to Ecology and the EPA in April 1987. A Tri-Party Agreement change request was approved to coordinate the closure plan with the past-practice documentation for the 200-BP-11 Operable Unit. In March 1995, Draft B of the Work Plan for the 200-BP-11 Operable Unit was issued and incorporated the 216-B-63 Trench. This Work Plan integrates the TSD activities with the 200-BP-11 Operable Unit documentation and characterization. The 216-B-63 Trench is scheduled to be incorporated into the HF RCRA Permit (DW Portion) in Modification F, calendar year 2000.

Prepared by: Westinghouse Hanford Company

Date: July 31,1996 Environmental Services 
The following information was prepared in response to requirements of DOE Order 5400.2A.

DOE Operations Office: Richland

DOE Facility: Hanford Site

Existing Permit ( ) Renewal ( ) New Permit ( X)

Permit Type: RCRA Closure Plan

Permitting Agency: Washington State Department of Ecology

U.S. Environmental Protection Agency, Region 10

Permit Number: WA7890008967

Permitted Unit: 216-S-10 Pond and Ditch

Issuance Date:

Expiration Date:

Need for Headquarters' Action

(for permit renewals or new permits)
Yes ( ) No (X)

If yes, HQ Program Element

Brief Summary of Relevant Information (major permit conditions, status of compliance or unusual problems):

Part A, Form 3, dangerous waste permit application documentation for the 216-S-10 Pond and Ditch originally was submitted to Ecology and the EPA in February 1987. Three revisions of the Part A, Form 3, dangerous waste permit application documentation have been submitted.

The 216-S-10 Pond and Ditch Closure Plan was submitted to Ecology and the EPA in June 1987. Tri-Party Agreement Milestone M-20-39 requires submittal of an updated closure plan to Ecology by June 1999, coordinated with the past-practice documentation for the 200-RO-1 Operable Unit.

Prepared by: Bechtel Hanford, Inc.

Date: July 31, 1996

Regulatory Support 
The following information was prepared in response to requirements of DOE Order 5400.2A.

DOE Operations Office: Richland

DOE Facility: Hanford Site

Existing Permit (X) Renewal ( ) New Permit ( )

Permit Type: RCRA Closure Plan

Permitting Agency: Washington State Department of Ecology

Permit Number: WA7890008967

Permitted Unit: 218-E-8 Borrow Pit Demolition Site

Issuance Date: May 29, 1995 (Date Revision I of the HF RCRA Permit became effective, 30 days after perntit issuance.)

Expiration Date: September 27, 2004

Need for Headquarters' Action

(for permit renewals or new permits)
Yes ( ) No (X)

If yes, HQ Program Element

Brief Summary of Relevant Information (major permit conditions, status of compliance or unusual problems):

Part A, Form 3, and Part B dangerous waste permit application documentation for the 218-E-8 Borrow Pit Demolition Site originally was submitted to Ecology and the EPA in November 1985. Subsequently, a decision was made to close this TSD unit. Four revisions of the * Part A, Form 3, dangerous waste permit application documentation have been submitted.

Tri-Party Agreement Milestone M-20-28 was satisfied with the submittal of the 218-E-8 Borrow Pit Demolition Site Closure Plan to Ecology and the EPA in November 1992. Revision 1 of the closure plan was submitted to Ecology and the EPA in September 1994. Revision 1 of the 218-E-8 Borrow Pit Demolition Site Closure Plan was incorporated into Revision 1 of the HF RCRA Permit (DW Portion) that became effective on May 29, 1995. Closure certification was submitted to Ecology on September 22, 1995. On October 26, 1995, Ecology approved the clean closure certification. The Part A, Form 3, dangerous waste permit application documentation was stamped with "closed as of October 26, 1995" and submitted to Ecology on November 28, 1995.

Prepared by: Westinghouse Hanford Company

Date: July 31, 1996

Environmental Services 
The following information was prepared in response to requirements of DOE Order 5400.2A.

DOE Operations Office: Richland

DOE Facility: Hanford Site

Existing Permit (X) Renewal ( ) New Permit ( )

Permit Type: RCRA Closure Plan

Permitting Agency: Washington State Department of Ecology

Permit Number: WA7890008967

Permitted Unit: 300 Area Solvent Evaporator

Issuance Date: September 28, 1994 (Date Revision 0 of the HF RCRA Permit became effective, 30 days after permit issuance.)

Expiration Date: September 27, 2004

Need for Headquarters' Action

(for permit renewals or new permits)
Yes ( ) No ( $X)$

If yes, HQ Program Element

Brief Summary of Relevant Information (major permit conditions, status of compliance or unusual problems):

Part A, Form 3, dangerous waste permit application documentation for the 300 Area Solvent Evaporator originally was submitted to Ecology and the EPA in November 1985. Four revisions of the Part A, Form 3, dangerous waste permit application documentation have been submitted.

The 300 Area Solvent Evaporator Closure Plan was submitted to Ecology and the EPA in February 1989. Revision 3B of the 300 Area Solvent Evaporator Closure Plan was incorporated into Revision 0 of the HF RCRA Permit (DW Portion) that became effective on September 28, 1994. Closure certification was submitted to Ecology on May 25, 1995. On June 27, 1995, Ecology approved the clean closure certification. The Part A, Form 3, dangerous waste permit application documentation was stamped with "closed as of June 27, 1995" and submitted to Ecology on July $31,1995$.

Prepared by: Westinghouse Hanford Company

Date: July 31, 1996 Environmental Services 
The following information was prepared in response to requirements of DOE Order 5400.2A.

DOE Operations Office: Richland

DOE Facility: Hanford Site

Existing Permit ( ) Renewal ( ) New Permit (X)

Permit Type: RCRA Closure Plan

Permitting Agency: Washington State Department of Ecology

Permit Number: WA7890008967

Permitted Unit: 300 Area Waste Acid Treatment System

Issuance Date:

Expiration Date:

Need for Headquarters' Action

(for permit renewals or new permits)
Yes ( ) No (X)

If yes, HQ Program Element

Brief Summary of Relevant Information (major permit conditions, status of compliance or unusual problems):

Part A, Form 3, dangerous waste permit application documentation for the 300 Area Waste Acid Treatment System originally was submitted to Ecology and the EPA in September 1987. Four revisions of the Part A, Form 3, dangerous waste permit application documentation have been submitted.

Tri-Party Agreement Milestone M-20-10 was satisfied with the submittal of the 300 Area Waste Acid Treatment System Closure Plan to Ecology and the EPA in June 1990. Revision 1 of the closure plan was submitted to the regulators on April 9, 1996. The 300 Area Waste Acid Treatment System is scheduled to be incorporated into the HF RCRA Permit (DW Portion) in Modification C, December 1997.

Prepared by: Westinghouse Hanford Company

Date: July 31,1996

Environmental Services 
The following information was prepared in response to requirements of DOE Order 5400.2A.

DOE Operations Office: Richland

DOE Facility: Hanford Site

Existing Permit ( ) Renewal ( ) New Permit (X)

Permit Type: RCRA Closure Plan

Permitting Agency: Washington State Department of Ecology

Permit Number: WA7890008967

Permitted Unit: 303-K Storage Facility

Issuance Date:

Expiration Date:

Need for Headquarters' Action

(for permit renewals or new permits)
Yes ( ) No (X)

If yes, HQ Program Element

Brief Summary of Relevant Information (major permit conditions, status of compliance or unusual problems):

Part A, Form 3, dangerous waste permit application documentation for the 303-K Storage Facility originally was submitted to Ecology and the EPA in August 1987. Four revisions of the Part A, Form 3, dangerous waste permit application documentation have been submitted.

Tri-Party Agreement Milestone M-20-13 was satisfied with the submittal of the 303-K Storage Facility Closure Plan to Ecology and the EPA in April 1990. All Notice of Deficiency comments were resolved. Revision 2A of the closure plan was submitted in July 1995. Ecology approved the closure plan on August 27, 1995. The 303-K Storage Facility is scheduled to be incorporated into Revision 3 of the HF RCRA Permit (DW Portion) scheduled to become effective in December 1996. Closure activities are expected to begin in October 1996.

Prepared by: Westinghouse Hanford Company

Date: July 31,1996 Environmental Services 
The following information was prepared in response to requirements of DOE Order $5400.2 \mathrm{~A}$.

DOE Operations Office: Richland

DOE Facility: Hanford Site

Existing Permit ( ) Renewal ( ) New Permit (X)

Permit Type: RCRA

Permitting Agency: Washington State Department of Ecology

U.S. Environmental Protection Agency, Region 10

Permit Number: WA7890008967

Permitted Unit: $303-M$ Oxide Facility

Issuance Date:

Expiration Date:

Need for Headquarters' Action

(for permit renewals or new permits)
Yes ( ) No ( $X$ )

If yes, HQ Program Element

Brief Summary of Relevant Information (major permit conditions, status of compliance or unusual problems):

Part A, Form 3, dangerous waste permit application documentation for the 303-M Oxide Facility originally was submitted to Ecology and the EPA in May 1988. No revisions of the Part A, Form 3, dangerous waste permit application documentation have been submitted.

Tri-Party Agreement Milestone M-20-30 required submittal of the Part B dangerous waste permit application documentation to Ecology and the EPA by October 1992. A Tri-Party Agreement Change Request (M-20-92-05) was submitted to Ecology and the EPA to delete the existing milestone for submittal of the Part B dangerous waste permit application documentation in October 1992. The Tri-Party Agreement Change Request was approved on December 15, 1993, to integrate this unit with the 300-FF-2 Operable Unit Work Plan.

Prepared by: Westinghouse Hanford Company

Date: July 31, 1996 Environmental Services 
The following information was prepared in response to requirements of DOE Order 5400.2A.

DOE Operations Office: Richland

DOE Facility: Hanford Site

Existing Permit ( ) Renewal ( ) New Permit (X)

Permit Type: RCRA Closure Plan

Permitting Agency: Washington State Department of Ecology

Permit Number: WA7890008967

Permitted Unit: 304 Concretion Facility

Issuance Date: September 28, 1995 (Date Revision 2 of the HF RCRA Permit became effective, 30 days after permit issuance.)

Expiration Date: September 27, 2004

Need for Headquarters' Action

Yes ( ) No ( $X)$

(for permit renewals or new permits)

If yes, HQ Program Element

Brief Summary of Relevant Information (major permit conditions, status of compliance or unusual problems):

Part A, Form 3, dangerous waste permit application documentation for the 304 Concretion Facility originally was submitted to Ecology and the EPA in August 1986. Four revisions of the Part A, Form 3, dangerous waste permit application documentation have been submitted.

Tri-Party Agreement Milestone M-20-15 was satisfied with the submittal of the 304 Concretion Facility Closure Plan to Ecology and the EPA in April 1990. Revision 2A of the 304 Concretion Facility Closure Plan was incorporated into Revision 2 of the HF RCRA Permit (DW Portion) that became effective on September 28, 1995. Closure certification was submitted to Ecology on October 27, 1995. On November 30, 1995, Ecology approved the clean closure certification. The Part A, Form 3, dangerous waste permit application documentation was stamped with "closed as of November 30, 1995" and submitted to Ecology on January 21, 1996.

Prepared by: Westinghouse Hanford Company

Date: July 31,1996 Environmental Services 
The following information was prepared in response to requirements of DOE Order 5400.2A.

DOE Operations Office: Richland

DOE Facility: Hanford Site

Existing Permit ( ) Renewal ( ) New Permit (X)

Permit Type: RCRA Closure Plan

Permitting Agency: Washington State Department of Ecology

U.S. Environmental Protection Agency, Region 10

Permit Number: WA7890008967

Permitted Unit: 1324-N Surface Impoundment

Issuance Date:

Expiration Date:

Need for Headquarters' Action

(for permit renewals or new permits)
Yes ( ) No (X)

If yes, HQ Program Element

Brief Summary of Relevant Information (major permit conditions, status of compliance or unusual problems):

Part A, Form 3, dangerous waste permit application documentation for the 1324-N Surface Impoundment originally was submitted to Ecology and the EPA in August 1986. Three revisions * of the Part A, Form 3, dangerous waste permit application documentation have been submitted.

This TSD unit will be included in the 1324-N Surface Impoundment and 1324-NA Percolation Pond Closure Plan. Tri-Party Agreement Milestone M-20-35 requires subinittal of an updated 1324-N Surface Impoundment and 1324-NA Percolation Pond Closure and Postclosure Plan to Ecology and the EPA by September 30, 1994. Tri-Party Agreement change request M-20-94-01 was approved on May 20,1994, changing the submittal date of an updated closure and postclosure plan to a "to be determined". This unit will be included as an attachment to the corrective measures study for the 100-N Area TSD units. The 1324-N Surface Impoundment is scheduled to be incorporated into the HF RCRA Permit (DW Portion) in Modification D, calendar year 1998.

Prepared by: Bechtel Hanford, Inc.

Date: July 31,1996

Regulatory Support 
The following information was prepared in response to requirements of DOE Order 5400.2A.

DOE Operations Office: Richland

DOE Facility: Hanford Site

Existing Permit ( ) Renewal ( ) New Permit (X)

Permit Type: RCRA Closure Plan

Permitting Agency: Washington State Department of Ecology

U.S. Environmental Protection Agency, Region 10

Permit Number: WA7890008967

Permitted Unit: 1324-NA Percolation Pond

Issuance Date:

Expiration Date:

Need for Headquarters' Action

(for permit renewals or new permits)
Yes ( ) No ( $\mathrm{X}$ )

If yes, HQ Program Element

Brief Summary of Relevant Information (major permit conditions, status of compliance or unusual problems):

Part A, Form 3, dangerous waste permit application documentation for the 1324-NA Percolation Pond originally was submitted to Ecology and the EPA in August 1986. Three revisions of the Part A, Form 3, dangerous waste permit application documentation have been submitted.

The 1324-NA Percolation Pond Closure Plan originally was submitted to Ecology and the EPA in April 1987. This TSD unit will be included in the 1324-N Surface Impoundment and 1324-NA Percolation Pond Closure Plan. Tri-Party Agreement Milestone M-20-35 requires submittal of an updated 1324-N Surface Impoundment and 1324-NA Percolation Pond Closure and Postclosure Plan to Ecology and the EPA by September 30, 1994. Tri-Party Agreement change request M-20-94-01 was approved on May 20, 1994, changing the submittal date of an updated closure and postclosure plan to a "to be determined". This unit will be included as an attachment to the corrective measures study for the 100-N Area TSD units. The 1324-NA Percolation Pond is scheduled to be incorporated into the HF RCRA Permit (DW Portion) in Modification D, calendar year 1998 .

Prepared by: Bechtel Hanford, Inc.

Date: July 31, 1996

Regulatory Support 
The following information was prepared in response to requirements of DOE Order 5400.2A.

DOE Operations Office: Richland

DOE Facility: Hanford Site

Existing Permit (X) $\quad$ Renewal ( ) New Permit ( )

Permit Type: RCRA Closure Plan

Permitting Agency: Washington State Department of Ecology

Permit Number: WA7890008967

Permitted Unit: 2101-M Pond

Issuance Date: May 29, 1995 (Date Revision I of the HF RCRA Permit became effective, 30 days after pemit issuance.)

Expiration Date: September 27, 2004

Need for Headquarters' Action

(for permit renewals or new permits)

Yes ( ) No (X)

If yes, HQ Program Element

Brief Summary of Relevant Information (major permit conditions, status of compliance or unusual problems):

Part A, Form 3, dangerous waste permit application documentation for the 2101-M Pond originally was submitted to Ecology and the EPA in August 1986. Two revisions of the Part A, Form 3, dangerous waste permit application documentation have been submitted.

Tri-Party Agreement Milestone M-20-04 was satisfied with the submittal of the 2101-M Pond Closure Plan to Ecology and the EPA in September 1989. Revision 2 of the closure plan was submitted on June 30, 1993. Revision 2 of the 2101-M Pond Closure Plan was incorporated into Revision 1 of the HF RCRA Permit (DW Portion) that became effective on May 29, 1995. Closure certification was submitted to Ecology on September 22, 1995. On October 26, 1995, Ecology approved the clean closure certification. The Part A, Form 3, dangerous waste permit application documentation was stamped with "closed as of October 26, 1995" and submitted to Ecology on November 28, 1995.

Prepared by: Westinghouse Hanford Company

Date: July 31, 1996 Environmental Services 
The following information was prepared in response to requirements of DOE Order 5400.2A.

DOE Operations Office: Richland

DOE Facility: Hanford Site

Existing Permit (X) Renewal ( ) New Permit ( )

Permit Type: RCRA Closure Plan

Permitting Agency: Washington State Department of Ecology

Permit Number: WA7890008967

Permitted Unit: 2727-S Storage Facility

Issuance Date: September 28, 1994 (Date Revision 0 of the HF RCRA Permit became effective, 30 days affer permit issuance.)

Expiration Date: September 27, 2004

Need for Headquarters' Action

Yes ( ) No ( $\mathrm{X})$

(for permit renewals or new permits)

If yes, HQ Program Element

Brief Summary of Relevant Information (major permit conditions, status of compliance or unusual problems):

Part A, Form 3, dangerous waste permit application documentation for the 2727-S Storage Facility originally was submitted to Ecology and the EPA in November 1985. Two revisions of the Part A, Form 3, dangerous waste permit application documentation have been submitted.

The 2727-S Storage Facility Closure Plan originally was submitted to Ecology and the EPA in February 1989. Revision 3 of the 2727-S Storage Facility Closure Plan was incorporated into Revision 0 of the HF RCRA Permit (DW Portion) that became effective on September 28, 1994. Closure certification was submitted to Ecology on May 25, 1995. On June 27, 1995, Ecology approved the clean closure certification. The Part A, Form 3, dangerous waste permit application documentation was stamped with "closed as of June 27, 1995" and submitted to Ecology on July $31,1995$.

Prepared by: Westinghouse Hanford Company

Date: July 31, 1996 Environmental Services 
The following information was prepared in response to requirements of DOE Order 5400.2A.

DOE Operations Office: Richland

DOE Facility: Hanford Site

Existing Permit ( ) Renewal ( ) New Permit (X)

Permit Type: RCRA Closure Plan

Permitting Agency: Washington State Department of Ecology

Permit Number: WA7890008967

Permitted Unit: 3718-F Alkali Metal Treatment and Storage Facility

Issuance Date:

Expiration Date:

Need for Headquarters' Action

$$
\begin{aligned}
& \text { Yes ( ) No (X) } \\
& \text { If yes, HQ Program Element }
\end{aligned}
$$

(for permit renewals or new permits)

Brief Summary of Relevant Information (major permit conditions, status of compliance or unusual problems):

Part A, Form 3, and Part B dangerous waste permit application documentation for the 3718-F Alkali Metal Treatment and Storage Facility originally was submitted to Ecology and the EPA in November 1985. Three revisions of the Part A, Form 3, dangerous waste permit application documentation have been submitted.

Tri-Party Agreement Milestone M-20-18 was satisfied with the submittal of the 3718-F Alkali Metal Treatment and Storage Facility Closure Plan in December 1991. All Notice of Deficiency comments have been resolved.. Revision 2 of the closure plan was submitted to Ecology on December 7, 1995, and approved by Ecology on January 30, 1996. The 3718-F Alkali Metal Treatment and Storage Facility is scheduled to be incorporated into Revision 3 of the HF RCRA Permit (DW Portion) scheduled to become effective in December 1996.

Prepared by: Westinghouse Hanford Company

Date: July 31,1996

$$
\text { Environmental Services }
$$


The following information was prepared in response to requirements of DOE Order $5400.2 \mathrm{~A}$.

DOE Operations Office: Richland

DOE Facility: Hanford Site

Existing Permit ( ) Renewal ( ) New Permit (X)

Permit Type: RCRA Closure Plan

Permitting Agency: Washington State Department of Ecology

Permit Number: WA7890008967

Permitted Unit: 4843 Alkali Metal Storage Facility

Issuance Date:

Expiration Date:

Need for Headquarters' Action

(for permit renewals or new permits)
Yes ( ) No ( X)

If yes, HQ Program Element

Brief Summary of Relevant Information (major permit conditions, status of compliance or unusual problems):

Part A, Form 3, dangerous waste permit application documentation for the 4843 Alkali Metal Storage Facility originally was submitted to Ecology and the EPA in September 1987. Two revisions of the Part $A$, Form 3, dangerous waste permit application documentation have been submitted.

Tri-Party Agreement Milestone M-20-14 was satisfied with the submittal of the 4843 Alkali Metal Storage Facility Closure Plan in June 1991. Revision 1 of the 4843 Alkali Metal Storage Facility Closure Plan was submitted to Ecology in September 1995, and approved by Ecology on February 16, 1996. All dangerous waste was removed from the 4843 Alkali Metal Storage Facility by May 10, 1995. The 4843 Alkali Metal Storage Facility is scheduled to be incorporated into Revision 3 of the HF RCRA Permit (DW Portion) scheduled to become effective in December 1996.

Prepared by: Westinghouse Hanford Company

Date: July 31, 1996 Environmental Services 
The following information was prepared in response to requirements of DOE Order 5400.2A.

DOE Operations Office: Richland

DOE Facility: Hanford Site

Existing Permit ( ) Renewal ( ) New Permit (X)

Permit Type: RCRA

Permitting Agency: Washington State Department of Ecology

Permit Number: WA7890008967

Permitted Unit: B Plant Complex

Issuance Date:

Expiration Date:

Need for Headquarters' Action

(for permit renewals or new permits)
Yes ( ) No (X)

If yes, HQ Program Element

Brief Summary of Relevant Information (major permit conditions, status of compliance or unusual problems):

Part A, Form 3, dangerous waste permit application documentation for the B Plant Complex originally was submitted to Ecology and the EPA in November 1987. Four revisions of the Part A, Form 3, dangerous waste permit application documentation have been submitted.

The B Plant Complex will be decommissioned and will not require a Part B dangerous waste permit application documentation. As part of the transition-phase of decommissioning, Tri-Party Agreement Milestone M-20-21A will be satisfied with a preclosure work plan. Preparation of the preclosure work plan is scheduled to start in July of 1997.

Prepared by: Westinghouse Hanford Company

Date: July 31, 1996 Environmental Services 
The following information was prepared in response to requirements of DOE Order $5400.2 \mathrm{~A}$.

DOE Operations Office: Richland

DOE Facility: Hanford Site

Existing Permit ( ) Renewal ( ) New Permit (X)

Permit Type: RCRA Closure Plan

Permitting Agency: Washington State Department of Ecology

Permit Number: WA7890008967

Permitted Unit: Hanford Patrol Academy Demolition Sites

Issuance Date: September 28, 1995 (Date Revision 2 of the HF RCRA Permit became effective, 30 days after pennit issuance.)

Expiration Date: September 27, 2004

Need for Headquarters' Action

(for permit renewals or new permits)
Yes ( ) No (X)

If yes, HQ Program Element

Brief Summary of Relevant Information (major permit conditions, status of compliance or unusual problems):

Part A, Form 3, and Part B dangerous waste permit application documentation for the Hanford Patrol Academy Demolition Sites originally was submitted to Ecology and the EPA in November 1985. Subsequently, a decision was made to close this TSD unit. Four revisions of the Part A, Form 3 , dangerous waste permit application documentation have been submitted.

Tri-Party Agreement Milestone M-20-25 was satisfied with the submittal of the Hanford Patrol Academy Demolition Sites Closure Plan to Ecology and the EPA in November 1992. Revision 1 of the Hanford Patrol Academy Demolition Sites Closure Plan was incorporated into Revision 2 of the HF RCRA Permit (DW Portion) that became effective on September 28, 1995. Closure certification was submitted to Ecology on September 22, 1995. On October 26, 1995, Ecology approved the clean closure certification. The Part A, Form 3, dangerous waste permit application documentation was stamped with "closed as of October 26,1995" and submitted to Ecology on November 28, 1995.

Prepared by: Westinghouse Hanford Company

Date: July 31,1996

Environmental Services 
The following information was prepared in response to requirements of DOE Order 5400.2A.

DOE Operations Office: Richland

DOE Facility: Hanford Site

Existing Permit ( ) Renewal ( ) New Permit (X)

Permit Type: RCRA Closure Plan

Permitting Agency: Washington State Department of Ecology

Permit Number: WA7890008967

Permitted Unit: Hexone Storage and Treatment Facility

Issuance Date:

Expiration Date:

Need for Headquarters' Action

(for permit renewals or new permits)
Yes ( ) No ( X)

If yes, HQ Program Element

Brief Summary of Relevant Information (major permit conditions, status of compliance or unusual problems):

Part A, Form 3, dangerous waste permit application documentation for the Hexone Storage and Treatment Facility originally was submitted to Ecology and the EPA in December 1987. Three revisions of the Part A, Form 3, dangerous waste permit application documentation have been submitted.

Tri-Party Agreement Milestone M-20-27 was satisfied with the submittal of the Hexone Storage and Treatment Facility Closure Plan to Ecology and the EPA in November 1992. Notice of Deficiency comments were received from Ecology on April 20, 1993. The Notice of Deficiency response table was submitted to Ecology and the EPA on July 19, 1993. The Notice of Deficiency response table is under review by the regulators.

Prepared by: Bechtel Hanford, Inc.

Date: July 31, 1996

Regulatory Support 
The following information was prepared in response to requirements of DOE Order 5400.2A.

DOE Operations Office: Richland

DOE Facility: Hanford Site

Existing Permit ( ) Renewal ( ) New Permit (X)

Permit Type: RCRA Closure Plan

Permitting Agency: Washington State Department of Ecology

Permit Number: WA7890008967

Permitted Unit: PUREX Plant

Issuance Date:

Expiration Date:

Need for Headquarters' Action

(for permit renewals or new permits)
Yes ( ) No (X)

If yes, HQ Program Element

Brief Summary of Relevant Information (major permit conditions, status of compliance or unusual problems):

Part A, Form 3, dangerous waste permit application documentation for the PUREX Plant originally was submitted to Ecology and the EPA in November 1987. Seven revisions of the Part A, Form 3, dangerous waste permit application documentation have been submitted.

Tri-Party Agreement Milestone M-20-24 required submittal of the Part B dangerous waste permit application documentation to Ecology and the EPA by September 1992. In December 1992, DOE-Headquarters determined that the PUREX Plant would no longer operate and directed the PUREX Plant to deactivate. Tri-Party Agreement Change Request M-80-94-01, was approved to support the PUREX Facility decommissioning and closure process. Tri-Party Agreement Milestone M-80-02 was fulfilled with the submittal of the following documentation: 1) PUREX Facility Preclosure Work Plan, July 12, 1996; 2) PUREX Facility Surveillance and Maintenance Plan, May 16, 1996; and 3) PUREX Facility End Point Criteria, June 21, 1995. Submittal of the PUREX Facility Preclosure Work Plan also fulfilled Tri-Party Agreement Milestone M-20-24A.

Prepared by: Westinghouse Hanford Company

Date: July 31,1996 Environmental Services 
The foilowing information was prepared in response to requirements of DOE Order $5400.2 \mathrm{~A}$.

DOE Operations Office: Richland

DOE Facility: Hanford Site

Existing Permit (X) Renewal ( ) New Permit ()

Permit Type: RCRA Closure Plan

Permitting Agency: Washington State Department of Ecology

Permit Number: WA7890008967

Permitted Unit: Simulated High-Level Waste Slurry Treatment/Storage

Issuance Date: May 29, 1995 (Date Revision I of the HF RCRA Permit became effective, 30 days affer permit issuance),

Expiration Date: September 27, 2004

Need for Headquarters' Action

Yes ( ) No ( $\mathrm{X}$ )

(for permit renewals or new permits)

If yes, HQ Program Element

Brief Summary of Relevant Information (major permit conditions, status of compliance or unusual problems):

Part A, Form 3, dangerous waste permit application documentation for the Simulated High-Level Waste Slurry Treatment/Storage originally was submitted to Ecology and the EPA in May 1988. Two revisions of the Part A, Form 3, dangerous waste permit application documentation have been submitted.

Tri-Party Agreement Milestone M-20-19 was satisfied with the submittal of the Simulated High-Level Waste Slurry Treatment/Storage Closure Plan to Ecology and the EPA in September 1989. Revision 6 of the closure plan was submitted to Ecology and the EPA on July 29, 1994. Revision 6 of the Simulated High-Level Waste Slurry Treatment/Storage Closure Plan was incorporated into Revision 1 of the HF RCRA Permit (DW Portion) that became effective on May 29, 1995. Closure certification was submitted to Ecology on August 27, 1995. On September 6, 1995, Ecology approved the clean closure certification. The Part A, Form 3, dangerous waste permit application documentation was stamped with "closed as of September 6, 1995" and submitted to Ecology on October 23, 1995.

Prepared by: Pacific Northwest National Laboratory

Date: July 31, 1996 Environmental Compliance 
DOE/RL-96-63, Rev. 0

$10 / 96$

This page intentionally left blank. 
DOE/RL-96-63, Rev. 0

$10 / 96$

\section{RESOURCE CONSERVATION AND RECOVERY ACT CLOSURE AND POSTCLOSURE PLANS}


DOE/RL-96-63, Rev. 0

$10 / 96$

This page intentionally left blank.

4 
The following information was prepared in response to requirements of DOE Order 5400.2A.

DOE Operations Office: Richland

DOE Facility: Hanford Site

Existing Permit ( ) Renewal ( ) New Permit (X)

Permit Type: RCRA Closure and Postclosure Plan

Permitting Agency: Washington State Department of Ecology

U.S. Environmental Protection Agency, Region 10

Permit Number: WA7890008967

Permitted Unit: 216-A-10 Crib

Issuance Date:

Expiration Date:

Need for Headquarters' Action

(for permit renewals or new permits)
Yes ( ) No ( $\mathrm{X})$

If yes, HQ Program Element

Brief Summary of Relevant Information (major permit conditions, status of compliance or unusual problems):

Part A, Form 3, dangerous waste permit application documentation for the 216-A-10 Crib originally was submitted to Ecology and the EPA in August 1987. Three revisions of the Part A, Form 3, dangerous waste permit application documentation have been submitted.

Tri-Party Agreement Milestone M-20-33 requires submittal of the 216-A-10 Crib Closure and Postclosure Plan to Ecology and the EPA by June 1998, coordinated with the past-practice documentation for the 200-PO-2 Operable Unit.

Prepared by: Bechitel Hanford, Inc.

Date: July 31,1996

Regulatory Support 
The following information was prepared in response to requirements of DOE Order 5400.2A.

DOE Operations Office: Richland

DOE Facility: Hantord Site

Existing Permit ( ) $\quad$ Renewal ( ) New Permit (X)

Permit Type: RCRA Closure and Postclosure Plan

Permitting Agency: Washington State Department of Ecology

U.S. Environmental Protection Agency, Region 10

Permit Number: WA7890008967

Permitted Unit: 216-A-29 Ditch

Issuance Date:

Expiration Date:

Need for Headquarters' Action

(for permit renewals or new permits)
Yes ( ) No (X)

If yes, HQ Program Element

Brief Summary of Relevant Information (major permit conditions, status of compliance or unusual problems):

Part A, Form 3, dangerous waste permit application documentation for the 216-A-29 Ditch originally was submitted to Ecology and the EPA in August 1986. Three revisions of the Part A, Form 3, dangerous waste permit application documentation have been submitted.

The 216-A-29 Ditch Closure Plan originally was submitted to Ecology and the EPA in April 1987. Tri-Party Agreement Milestone M-20-36 was satisfied on April 3, 1995, with the submittal to Ecology and the EPA of the 216-A-29 Ditch Closure and Postclosure Plan coordinated with the past-practice documentation for the 200-BP-11 Operable Unit. The 216-A-29 Ditch is scheduled to be incorporated into the HF RCRA Permit (DW Portion) in Modification F, calendar year 2000.

Prepared by: Bechtel Hanford, Inc.

Date: July 31, 1996

Regulatory Support 
The following information was prepared in response to requirements of DOE Order 5400.2A.

DOE Operations Office: Richland

DOE Facility: Hanford Site

Existing Permit ( ) Renewal ( ) New Permit (X)

Permit Type: RCRA Closure and Postclosure Plan

Permitting Agency: Washington State Department of Ecology

U.S. Environmental Protection Agency, Region 10

Permit Number: WA7890008967

Permitted Unit: 216-A-36B Crib

Issuance Date:

Expiration Date:

Need for Headquarters' Action

(for permit renewals or new permits)
Yes ( ) No (X)

If yes, HQ Program Element

Brief Summary of Relevant Information (major permit conditions, status of compliance or unusual problems):

Part A, Form 3, dangerous waste permit application documentation for the 216-A-36B Crib originally was submitted to Ecology and the EPA in February 1988. One revision of the Part A, Form 3, dangerous waste permit application documentation has been submitted.

The 216-A-36B Crib Closure Plan originally was submitted to Ecology and the EPA in February 1988. Tri-Party Agreement Milestone M-20-33 requires submittal of an updated closure and postclosure plan to Ecology and the EPA by June 1998, coordinated with the past-practice documentation for the 200-PO-2 Operable Unit.

Prepared by: Bechtel Hanford, Inc.

Date: July 31, 1996

Regulatory Support 
The following information was prepared in response to requirements of DOE Order 5400.2A.

DOE Operations Office: Richland

DOE Facility: Hanford Site

Existing Permit ( ) Renewal ( ) New Permit (X)

Permit Type: RCRA Closure and Postclosure Plan

Permitting Agency: Washington State Department of Ecology

U.S. Environmental Protection Agency, Region 10

Permit Number: WA7890008967

Permitted Unit: 216-A-37-1 Crib

Issuance Date:

Expiration Date:

Need for Headquarters' Action

(for permit renewals or new permits)
Yes ( ) No ( X)

If yes, HQ Program Element

Brief Summary of Relevant Information (major permit conditions, status of compliance or unusual problems):

Part A, Form 3, dangerous waste permit application documentation for the 216-A-37-1 Crib originally was submitted to Ecology and the EPA in February 1990. Two revisions of the Part A, Form 3, dangerous waste permit application documentation have been submitted.

Tri-Party Agreement Milestone M-20-52 was established to coordinate the 216-A-37-1 Crib Closure and Postclosure Plan with the past-practice documentation for the 200-PO-4 Operable Unit. The submittal date for this documentation is October 1998.

Prepared by: Bechtel Hanford, Inc.

Date: July 31,1996

Regulatory Support 
The following information was prepared in response to requirements of DOE Order 5400.2A.

DOE Operations Office: Richland

DOE Facility: Hanford Site

Existing Permit ( ) Renewal ( ) New Permit (X)

Permit Type: RCRA Closure and Postclosure Plan

Permitting Agency: Washington State Department of Ecology

U.S. Environmental Protection Agency, Region 10

Permit Number: WA7890008967

Permitted Unit: 216-B-3 Main Pond and 216-B-3-3 Ditch

Issuance Date:

Expiration Date:

Need for Headquarters' Action

(for permit renewals or new permits)
Yes ( ) No (X)

If yes, HQ Program Element

Brief Summary of Relevant Information (major permit conditions, status of compliance or unusual problems):

Originally the 216-B-3 Expansion Ponds were included with the 216-B-3 Pond Main Lobe, in a single Part A, Form 3, dangerous waste permit application documentation. In December 1993, the 216-B-3 Pond System Part A, Form 3, was separated into two Part A, Form 3s: one for the 216-B-3 Expansion Ponds and one for the 216-B-3 Main Pond and 216-B-3-3 Ditch. Five revisions of the Part A, Form 3, dangerous waste permit application documentation have been submitted.

Tri-Party Agreement Milestone M-13-07 directed the closure of the 216-B-3 Main Pond and 216-B-3-3 Ditch coordinated with RCRA past-practice activities at the 200-BP-11 Operable Unit. Submittal of the coordinated work and closure plan was completed September 30, 1994. To address the recently increased scope of the 200-BP-11 Operable Unit, draft B of the document was submitted to Ecology and the EPA in April 1995 to meet Milestone M-20-36. The 216-B-3 Main Pond and 216-B-3-3 Ditch is scheduled to be incorporated into the HF RCRA Permit (DW Portion) in Modification F, calendar year 2000 .

Prepared by: Bechtel Hanford, Inc.

Date: July 31, 1996

Regulatory Support 
The following information was prepared in response to requirements of DOE Order $5400.2 \mathrm{~A}$.

DOE Operations Office: Richland

DOE Facility: Hanford Site

Existing Permit ( ) Renewal ( ) New Permit (X)

Permit Type: RCRA Closure and Postclosure Plan

Permitting Agency: Washington State Department of Ecology

U.S. Environmental Protection Agency, Region 10

Permit Number: WA7890008967

Permitted Unit: 216-U-12 Crib

Issuance Date:

Expiration Date:

Need for Headquarters' Action Yes ( ) No (X)

(for permit renewals or new permits) If yes, HQ Program Element

Brief Summary of Relevant Information (major permit conditions, status of compliance or unusual problems):

Part A, Form 3, dangerous waste permit application documentation for the 216-U-12 Crib originally was submitted to Ecology and the EPA in August 1987. Three revisions of the Part A, Form 3, dangerous waste permit application documentation have been submitted.

Tri-Party Agreement Milestone M-20-37 was satisfied on June 27, 1995, with the submittal to Ecology and the EPA of the 216-U-12 Crib Closure and Postclosure Plan coordinated with the past-practice documentation for the 200-UP-2 Operable Unit. The 216-U-12 Crib is scheduled to be incorporated into the HF RCRA Permit (DW Portion) in Modification C, December 1997.

Prepared by: Bechtel Hanford, Inc.

Date: July 31,1996

Regulatory Support 
The following information was prepared in response to requirements of DOE Order 5400.2A.

DOE Operations Office: Richland

DOE Facility: Hanford Site

$\begin{array}{lll}\text { Existing Permit ( ) } & \text { Renewal ( ) New Permit (X) }\end{array}$

Permit Type: RCRA Closure and Postclosure Plan

Permitting Agency: Washington State Department of Ecology

U.S. Environmental Protection Agency, Region 10

Permit Number: WA7890008967

Permitted Unit: 241-CX Tank System

Issuance Date:

Expiration Date:

Need for Headquarters' Action

(for permit renewals or new permits)
Yes ( ) No (X)

If yes, HQ Program Element

Brief Summary of Relevant Information (major permit conditions, status of compliance or unusual problems):

Part A, Form 3, dangerous waste permit application documentation for the 241-CX Tank System originally was submitted to Ecology and the EPA in July 1990. Three revisions of the Part A, Form 3, dangerous waste permit application documentation have been submitted.

A Tri-Party Agreement change request is being prepared to coordinate the 241-CX Tank System Closure Plan with the past-practice documentation for the 200-SO-1 Operable Unit. The submittal date for this documentation will be negotiated with Ecology and the EPA.

Prepared by: Bechtel Hanford, Inc.

Date: July 31, 1996

Regulatory Support 
The following information was prepared in response to requirements of DOE Order 5400.2A.

DOE Operations Office: Richland

DOE Facility: Hanford Site

Existing Permit ( ) Renewal ( ) New Permit (X)

Permit Type: RCRA Closure and Postclosure Plan

Permitting Agency: Washington State Department of Ecology

U.S. Environmental Protection Agency, Region 10

Permit Number: WA7890008967

Permitted Unit: 300 Area Process Trenches

Issuance Date:

Expiration Date:

Need for Headquarters' Action

(for permit renewals or new permits)

$$
\text { Yes ( ) No (X) }
$$

If yes, HQ Program Element

Brief Summary of Relevant Information (major permit conditions, status of compliance or unusual problems):

Part A, Form 3, dangerous waste permit application documentation for the 300 Area Process Trenches originally was submitted to Ecology and the EPA in November 1985. Four revisions of the Part A, Form 3, dangerous waste permit application documentation have been submitted.

Tri-Party Agreement Milestone M-20-32 was satisfied on August 15, 1994, with the submittal to Ecology and the EPA of an updated closure and postclosure plan. The 300 Area Process Trenches are scheduled to be incorporated into Revision 3 of the HF RCRA Permit (DW Portion) scheduled to become effective in December 1996. 
The following information was prepared in response to requirements of DOE Order $5400.2 \mathrm{~A}$.

DOE Operations Office: Richland

DOE Facility: Hanford Site

Existing Permit ( ) Renewal ( ) New Permit (X)

Permit Type: RCRA Closure and Postclosure Plan

Permitting Agency: Washington State Department of Ecology

U.S. Environmental Protection Agency, Region 10

Permit Number: WA7890008967

Permitted Unit: 1301-N Liquid Waste Disposal Facility

Issuance Date:

Expiration Date:

Need for Headquarters' Action

(for permit renewals or new permits)
Yes ( ) No (X)

If yes, HQ Program Element

Brief Summary of Relevant Information (major permit conditions, status of compliance or unusual problems):

Part A, Form 3, dangerous waste permit application documentation for the 1301-N Liquid Waste Disposal Facility originally was submitted to Ecology and the EPA in August 1986; documentation for the 1325-N Liquid Waste Disposal Facility originally was submitted in February 1987. Five revisions of the Part A, Form 3, dangerous waste permit application documentation for these TSD units have been submitted.

Tri-Party Agreement Milestone M-20-31 required the submittal of an updated 1301-N and 1325-N Liquid Waste Disposal Facility Closure and Postclosure Plan to Ecology and the EPA by May 31, 1994. Tri-Party Agreement change request M-20-94-01 was approved on May 20, 1994, changing the submittal date of the updated closure and postclosure plan to a "to be determined". This unit will be included as an attachment to the corrective measures study for the $100-\mathrm{N}$ Area TSD units. The 1301-N Liquid Waste Disposal Facility is scheduled to be incorporated into the HF RCRA Permit (DW Portion) in Modification E, calendar year 1999.

Prepared by: Bechtel Hanford, Inc.

Date: July 31, 1996

Regulatory Support 
The following information was prepared in response to requirements of DOE Order 5400.2A.

DOE Operations Office: Richland

DOE Facility: Hanford Site

Existing Permit ( ) Renewal ( ) New Permit (X)

Permit Type: RCRA Closure and Postclosure Plan

Permitting Agency: Washington State Department of Ecology

U.S. Environmental Protection Agency, Region 10

Permit Number: WA7890008967

Permitted Unit: 1325-N Liquid Waste Disposal Facility

Issuance Date:

Expiration Date:

Need for Headquarters' Action

(for permit renewals or new permits)

\section{Yes ( ) No (X)}

If yes, HQ Program Element

Brief Summary of Relevant Information (major permit conditions, status of compliance or unusual problems):

Part A, Form 3, dangerous waste permit application documentation for the 1301-N Liquid Waste Disposal Facility originally was submitted to Ecology and the EPA in August 1986; documentation for the 1325-N Liquid Waste Disposal Facility originally was submitted in February 1987. Five revisions of the Part A, Form 3, dangerous waste permit application documentation for these TSD units have been submitted.

Tri-Party Agreement Milestone M-20-31 required the submittal of an updated 1301-N and 1325-N Liquid Waste Disposal Facility Closure and Postclosure Plan to Ecology and the EPA by May 31, 1994. Tri-Party Agreement change request M-20-94-01 was approved on May 20, 1994, changing the submittal date of the updated closure and postclosure plan to a "to be determined". This unit will be included as an attachment to the corrective measures study for the 100-N Area TSD units. The 1325-N Liquid Waste Disposal Facility is scheduled to be incorporated into the HF RCRA Permit (DW Portion) in Modification E, calendar year 1999.

Prepared by: Bechtel Hanford, Inc.

Date: July 31, 1996

Regulatory Support 
The following information was prepared in response to requirements of DOE Order 5400.2A.

DOE Operations Office: Richland

DOE Facility: Hanford Site

Existing Permit ( ) Renewal ( ) New Permit (X)

Permit Type: RCRA Closure and Postclosure Plan

Permitting Agency: Washington State Department of Ecology

Permit Number: WA7890008967

Permitted Unit: Nonradioactive Dangerous Waste Landfill

Issuance Date:

Expiration Date:

Need for Headquarters' Action

(for permit renewals or new permits)
Yes ( ) No (X)

If yes, HQ Program Element

Brief Summary of Relevant Information (major permit conditions, status of compliance or unusual problems):

Part A, Form 3, and Part B dangerous waste permit application documentation for the Nonradioactive Dangerous Waste Landfill originally was submitted to Ecology and the EPA in November 1985. Subsequently, a decision was made to close this TSD unit. Four revisions of the Part A, Form 3, dangerous waste permit application documentation have been submitted.

Tri-Party Agreement Milestone M-20-07 was satisfied with the submittal of the Nonradioactive Dangerous Waste Landfill Closure and Postclosure Plan to Ecology and the EPA in August 1990. Ecology has requested that the DOE-RL evaluate clean closure. All information requested on clean closure has been reviewed by the regulatory agencies. Ecology issued partial Notice of Deficiency comments in January 1994. A Notice of Deficiency response table is being prepared to address the January 1994 comments.

Prepared by: Bechtel Hanford, Inc.

Date: July 31, 1996

Regulatory Support 
DOE/RL-96-63, Rev. 0

$10 / 96$

This page intentionally left blank. 
DOE/RL-96-63, Rev. 0

$10 / 96$

\section{RESOURCE CONSERVATION AND RECOVERY ACT}

CORRECTIVE ACTION WORK PLAN 
DOE/RL-96-63, Rev. 0 $10 / 96$

This page intentionally left blank. 
The following information was prepared in response to requirements of DOE Order 5400.2A.

DOE Operations Office: Richland

DOE Facility: Hanford Site

Existing Permit ( ) Renewal ( ) New Permit (X)

Permit Type: RCRA Closure and Corrective Action Work Plan

Permitting Agency: Washington State Department of Ecology

Permit Number: WA7890008967

Permitted Unit: Single-Shell Tank System

Issuance Date:

Expiration Date:

Need for Headquarters' Action

(for permit renewals or new permits)
Yes ( ) No (X)

If yes, HQ Program Element

Brief Summary of Relevant Information (major permit conditions, status of compliance or unusual problems):

Part A, Form 3, dangerous waste permit application documentation for the Single-Shell Tank System originally was submitted to Ecology and the EPA in February 1988. Three revisions of the Part A, Form 3, dangerous waste permit application documentation have been submitted.

Tri-Party Agreement Milestone M-20-03 was satisfied with the submittal of the Single-Shell Tank System Closure Work Plan (DOE/RL-89-16, Revision 0) to Ecology and the EPA in September 1989. A revised closure work plan (DOE/RL-89-16, Revision A) was provided to Ecology on June 13, 1995, in accordance with Tri-Party Agreement Milestone M-45-06. Ecology provided Notice of Deficiency comments on March 6, 1996. The Notice of Deficiency comments were resolved in April 1996. Revision 1 of the closure work plan (DOE/RL-89-16) was submitted to Ecology in May 1996.

Prepared by: Westinghouse Hanford Company

Date: July 31,1996 Environmental Services 
DOE/RL-96-63, Rev. 0

$10 / 96$

This page intentionally left blank. 
DOE/RL-96-63, Rev. 0

$10 / 96$

RCRA DELISTING PETITION 
DOE/RL-96-63, Rev. 0

$10 / 96$

This page intentionally left blank. 
The following information was prepared in response to requirements of DOE Order 5400.2A.

DOE Operations Office: Richland

DOE Facility: Hanford Site

Existing Permit (X) Renewal ( ) New Permit ( )

Permit Type: Delisting Approval - 40 CFR 260.20 and 260.22

Permitting Agency: U.S. Environmental Protection Agency, Region 10

Permit Number: N/A

Permitted Unit: 200 Area Effluent Treatment Facility

Issuance Date: June 13, 1995

Expiration Date: N/A

Need for Headquarters' Action

Yes ( ) No ( X)

(for permit renewals or new permits)

If yes, HQ Program Element

Brief Summary of Relevant Information (major permit conditions, status of compliance or unusual problems):

The 200 Area Effluent Treatment Facility Delisting Petition originally was submitted to the EPA in October 1992, with supporting documentation submitted in August 1993. Submittal of this delisting petition and a State Waste Discharge permit application in August of 1993 satisfied Consent Order DE $91 \mathrm{NM}-177$ requirements for discharge of liquid effluent from the Effluent Treatment Facility to the soil column.

The delisting petition was prepared to exempt the treated effluent from the 200 Area Effluent Treatment Facility from Subtitle C of RCRA. The delisting conditions include verification testing and monitoring requirements. Delisting enables disposal of the treated effluent to a State Approved Land Disposal Site. The EPA gave notice of their approval of the delisting petition in the Federal Register dated June 13, 1995.

Prepared by: Westinghouse Hanford Company

Date: July 31, 1996 Environmental Services 
DOE/RL-96-63, Rev. 0

10/96

This page intentionally left blank. 
DOE/RL-96-63, Rev. 0

$10 / 96$

SOLID WASTE HANDLING PERMITTING 
DOE/RL-96-63, Rev. 0

10/96

This page intentionally left blank. 
The following information was prepared in response to requirements of DOE Order $5400.2 \mathrm{~A}$.

DOE Operations Office: Richland

DOE Facility: Hanford Site

Existing Permit ( ) Renewal ( ) New Permit (X)

Permit Type: Solid Waste Handling Permit - WAC 173-304

Permitting Agency: Washington State Department of Ecology

Permit Number: N/A

Permitted Unit: Solid Waste Landfill

Issuance Date: N/A

Expiration Date: N/A

Need for Headquarters' Action

(for permit renewals or new permits)
Yes ( ) No (X)

If yes, HQ Program Element

Brief Summary of Relevant Information (major permit conditions, status of compliance or unusual problems):

The Solid Waste Handling Permit would have allowed disposal of nonhazardous, nonradioactive waste in the Solid Waste Landfill, located in the 600 Area, north of the Wye Barricade. The application was submitted to Ecology in November 1993. Ecology denied the application for a Solid Waste Handling Permit to operate the Solid Waste Landfill on March 14, 1995. The decision was based on groundwater contamination being detected in the underlying aquifer.

Ecology agreed that DOE-RL could continue interim operation of the landfill in the absence of a permit if a target shutdown date for the Solid Waste landfill was submitted and approved by Ecology. A target shutdown date of March 31, 1996, was submitted to Ecology and approved. The Solid Waste Landfill was permanently closed on March 31, 1996. An interim closure plan, Hanford Site Solid Waste Landfill Interim Closure Plan, DOE/RL-90-38, Revision 1, was prepared and submitted to Ecology on July 9, 1996.

Prepared by: Westinghouse Hanford Company

Date: July 31, 1996

Environmental Services 
DOE/RL-96-63, Rev. 0

$10 / 96$

This page intentionally left blank. 
DOE/RL-96-63, Rev. 0

\section{CLEAN AIR ACT PERMITTING}


DOE/RL-96-63, Rev. 0

$10 / 96$

This page intentionally left blank. 
The following information was prepared in response to requirements of DOE Order $5400.2 \mathrm{~A}$.

DOE Operations Office: Richland

DOE Facility: Hanford Site

Existing Permit (X) Renewal ( ) New Permit ( )

Permit Type: Radioactive Air Emissions Program, Radioactive Source Registration WAC 246-247

Permitting Agency: State of Washington Department of Health

Permit Number: FF-01

Permitted Unit: Hanford Site (Radioactive Air Emissions Program)

Issuance Date: August 15, 1993

Expiration Date: August 15, 1997

Need for Headquarters' Action

(for permit renewals or new permits)
Yes ( ) No (X)

If yes, HQ Program Element

Brief Summary of Relevant Information (major permit conditions, status of compliance or unusual problems):

This permit governs the operations of the emission sources in the 100, 200,300,400, and 600 Areas of the Hanford Site related to fuel reprocessing; radioactive waste handling; and disposal, research and development, and other nuclear operations having the potential-to-emit airborne radioactivity in excess or equal to 10 percent of the derived concentration guideline values. The major permit conditions include discharge points, efficiency values for control devices, effluent limitations on a daily and yearly basis, and continuous monitoring requirements.

Prepared by: Westinghouse Hanford Company

Date: July 31, 1996

Environmental Services 
The following information was prepared in response to requirements of DOE Order 5400.2A.

DOE Operations Office: Richland

DOE Facility: Hanford Site

Existing Permit ( ) Renewal ( ) New Permit (X)

Permit Type: Title V Operating Permit - 40 CFR 70

Permitting Agency: Washington State Department of Ecology

State of Washington Department of Health

U.S. Environmental Protection Agency, Region 10

Permit Number: TBD

Permitted Unit: Hanford Site (Title V Operating Permit)

Issuance Date: TBD

Expiration Date: TBD

Need for Headquarters' Action

Yes ( ) No (X)

(for permit renewals or new permits)

If yes, HQ Program Element

Brief Summary of Relevant Information (major permit conditions, status of compliance or unusual problems):

This permit will not create new requirements for emission units. The permit will list regulated pollutants emitted, identify and describe emission points (except insignificant emission units), provide emission rates, and describe fuels and other inputs or factors relating to emissions and emission control equipment. Radioactive and nonradioactive sources will be included. The permit application was submitted to Ecology and to the Department of Health on May 25, 1995. The permit application is updated quarterly until the permit is issued by Ecology. The permit is scheduled to be issued by Ecology the fourth quarter of 1997.

Prepared by: Westinghouse Hanford Company

Date: July 31,1996

Environmental Services 
The following information was prepared in response to requirements of DOE Order 5400.2A.

DOE Operations Office: Richland

DOE Facility: Hanford Site

Existing Permit ( ) Renewal ( ) New Permit (X)

Permit Type: Radioactive Air Emissions Program Notice of Construction - WAC 246-247

Permitting Agency: State of Washington Department of Health

Permit Number: Routine Technical Assistance Meeting

Permitted Unit: $100-\mathrm{K}$ East Storage Basin Fuel Canisters Movement

Issuance Date: September 1995

Expiration Date: NA

Need for Headquarters' Action

(for permit renewals or new permits)
Yes ( ) No ( $\mathrm{X}$ )

If yes, HQ Program Element

Brief Summary of Relevant Information (major permit conditions, status of compliance or unusual problems):

Approval of this Notice of Construction allowed the movement of up to 27 fuel canisters within the 100-K East Storage Basin. This relocation was necessary to accommodate canisters being transferred from PUREX. The movement of the canisters was completed with no compliance issues.

Prepared by: Westinghouse Hanford Company

Date: July 31, 1996 Environmental Services 
The following information was prepared in response to requirements of DOE Order 5400.2A.

DOE Operations Office: Richland

DOE Facility: Hanford Site

Existing Permit ( ) Renewal ( ) New Permit (X)

Permit Type: Radioactive Air Emissions Program Notice of Construction - WAC 246-247

Permitting Agency: State of Washington Department of Health

Permit Number: N/A

Permitted Unit: 105-C Reactor Interim Safe Storage

Issuance Date: TBD

Expiration Date: N/A

Need for Headquarters' Action

(for permit renewals or new permits)
Yes ( ) No ( $X)$

If yes, HQ Program Element

Brief Summary of Relevant Information (major permit conditions, status of compliance or unusual problems):

Approval of this Notice of Construction will allow the decontamination and demolition of unnecessary structures at $105-\mathrm{C}$ Reactor and the construction of the interim safe storage enclosure for the 105-C Reactor block. The Notice of Construction was submitted to the Department of Health for approval on July 18,1996 . Approval is pending.

Prepared by: Bechtel Hanford, Inc.

Date: July 31,1996

Regulatory Support 
The following information was prepared in response to requirements of DOE Order 5400.2A.

DOE Operations Office: Richland

DOE Facility: Hanford Site

Existing Permit ( ) Renewal ( ) New Permit (X)

Permit Type: National Emission Standard for Hazardous Air Pollutants (NESHAPs) 40 CFR 61, Subpart $H$

Permitting Agency: U.S. Environmental Protection Agency, Region 10

Permit Number: N/A

Permitted Unit: 105-C Reactor Interim Safe Storage

Issuance Date: TBD

Expiration Date: N/A

Need for Headquarters' Action

(for permit renewals or new permits)
Yes ( ) No (X)

If yes, HQ Program Element

Brief Summary of Relevant Information (major permit conditions, status of compliance or unusual problems):

Approval of this application will allow the decontamination and demolition of unnecessary structures at the 105 Reactor and the construction of the interim safe storage enclosure for the 105-C Reactor block. The application was submitted to the EPA for approval on July 18, 1996. Approval is pending. 
The following information was prepared in response to requirements of DOE Order 5400.2A.

DOE Operations Office: Richland

DOE Facility: Hanford Site

Existing Permit ( ) Renewal ( ) New Permit (X)

Permit Type: Radioactive Air Emissions Program Notice of Construction - WAC 246-247

Permitting Agency: State of Washington Department of Health

Permit Number: Routine Technical Assistance Meeting

Permitted Unit: 100-D Ponds Excavation of Radiologically Contaminated Soil

Issuance Date: May 14, 1996

Expiration Date: N/A

Need for Headquarters' Action

(for permit renewals or new permits)

Yes ( ) No (X)

If yes, HQ Program Element

Brief Summary of Relevant Information (major permit conditions, status of compliance or unusual problems):

Approval of this application allows the Environmental Restoration Contractor to excavate radiologically contaminated soil from 100-D Ponds. Approval was received from the Department of Health on May 14, 1996. This activity was completed with no compliance issues.

Prepared by: Bechtel Hanford, Inc.

Date: July 31, 1996

Regulatory Support 
The following information was prepared in response to requirements of DOE Order 5400.2A.

DOE Operations Office: Richland

DOE Facility: Hanford Site

Existing Permit ( ) Renewal ( ) New Permit (X)

Permit Type: National Emission Standard for Hazardous Air Pollutants (NESHAPs) 40 CFR 61, Subpart H

Permitting Agency: U.S. Environmental Protection Agency, Region 10

Permit Number: N/A

Permitted Unit: 100-D Ponds Excavation of Radiologically Contaminated Soil

Issuance Date: July 2, 1996

Expiration Date: N/A

Need for Headquarters' Action

(for permit renewals or new permits)
Yes ( ) No (X)

If yes, HQ Program Element

Brief Summary of Relevant Information (major permit conditions, status of compliance or unusual problems):

Approval of this application allows the Environmental Restoration Contractor to excavate radiologically contaminated soil from 100-D Ponds. Approval was received from the EPA on July 2 , 1996. This activity was completed with no compliance issues.

Prepared by: Bechtel Hanford, Inc.

Date: July 31, 1996

Regulatory Support 
The following information was prepared in response to requirements of DOE Order 5400.2A.

DOE Operations Office: Richland

DOE Facility: Hanford Site

Existing Permit ( ) Renewal ( ) New Permit (X)

Permit Type: Radioactive Air Emissions Program Notice of Construction - WAC 246-247

Permitting Agency: State of Washington Department of Health

Permit Number: Routine Technical Assistance Meeting

Permitted Unit: 100-K Basins Dose Reduction Activities

Issuance Date: January 1996

Expiration Date: NA

Need for Headquarters' Action

(for permit renewals or new permits)

\section{Yes ( ) No (X)}

If yes, HQ Program Element

Brief Summary of Relevant Information (major permit conditions, status of compliance or unusual problems):

Approval of this Notice of Construction allows dose reduction activities that would reduce air emissions within 100-K Basins. An example of this dose reduction activity would be the cleaning of the $100-\mathrm{K}$ Basin walls. During the period covered by this Status Report, these activities proceeded with no compliance issues.

Prepared by: Westinghouse Hanford Company

Date: July 31,1996

\author{
Environmental Services
}


The following information was prepared in response to requirements of DOE Order 5400.2A.

DOE Operations Office: Richland

DOE Facility: Hanford Site

Existing Permit ( ) $\quad$ Renewal ( ) New Permit (X)

Permit Type: Radioactive Air Emissions Program Notice of Construction - WAC 246-247

Permitting Agency: State of Washington Department of Health

Permit Number: Routine Technical Assistance Meeting

Permitted Unit: 100-K Basins Phase 2 Characterization

Issuance Date: January 1996

$\circ$

Expiration Date: NA

Need for Headquarters' Action

(for permit renewals or new permits)
Yes ( ) No (X)

If yes, HQ Program Element

Brief Summary of Relevant Information (major permit conditions, status of compliance or unusual problems):

Approval of this Notice of Construction allows the sampling/characterization approach to be taken for the 100-K Basins. Liquid samples taken for characterization are held in 20 milliliter vials and the sampling technique uses the same procedures as have been approved earlier. The 100-K Basins characterization is an ongoing activity. During the period covered by this Status Report, this activity proceeded with no compliance issues.

Prepared by: Westinghouse Hanford Company

Date: July 31,1996 Environmental Services 
The following information was prepared in response to requirements of DOE Order 5400.2A.

DOE Operations Office: Richland

DOE Facility: Hanford Site

Existing Permit ( ) Renewal ( ) New Permit (X)

Permit Type: Radioactive Air Emissions Program Notice of Construction - WAC 246-247

Permitting Agency: State of Washington Department of Health

Permit Number: Routine Technical Assistance Meeting

Permitted Unit: 100-K East Basin Air Sampling Equipment Reduction

Issuance Date: August 1995

Expiration Date: NA

Need for Headquarters' Action

Yes ( ) No (X)

(for permit renewals or new permits)

If yes, HQ Program Element

Brief Summary of Relevant Information (major permit conditions, status of compliance or unusual problems):

Approval of this Notice of Construction allows the reduction in air sampling equipment at 100-K East Basin. The approval was obtained with the condition that the monitor be left in place, in case operation of the monitor is needed during future activities in the basin. During the period covered by this Status Report, the $100-\mathrm{K}$ East Basin operated with no compliance issues.

Prepared by: Westinghouse Hanford Company

Date: July 31, 1996

Environmental Services 
The following information was prepared in response to requirements of DOE Order 5400.2A.

DOE Operations Office: Richland

DOE Facility: Hanford Site

Existing Permit ( ) Renewal ( ) New Permit ( X)

Permit Type: Radioactive Air Emissions Program Notice of Construction - WAC 246-247

Permitting Agency: State of Washington Department of Health

Permit Number: Routine Technical Assistance Meeting

Permitted Unit: 100-K East Basin Backwash Filter Test

Issuance Date: April 1996

Expiration Date: NA

Need for Headquarters' Action

(for permit renewals or new permits)
Yes ( ) No ( $\mathrm{X}$ )

If yes, HQ Program Element

Brief Summary of Relevant Information (major permit conditions, status of compliance or unusual problems):

Approval of this Notice of Construction allowed the testing of a packaged filtration unit. The 100-K East Basin water was pumped through the packaged unit, filtered, and returned to the 100-K East Basin. As the design dictated, the system automatically switched to a backwash mode and the backwash was collected in a holding tank. This testing activity was completed with no compliance issues.

Prepared by: Westinghouse Hanford Company

Date: July 31,1996

\section{Environmental Services}


The following information was prepared in response to requirements of DOE Order $5400.2 \mathrm{~A}$.

DOE Operations Office: Richland

DOE Facility: Hanford Site

Existing Permit ( ) Renewal ( ) New Permit (X)

Permit Type: Radioactive Air Emissions Program Notice of Construction - WAC 246-247

Permitting Agency: State of Washington Department of Health

Permit Number: Routine Technical Assistance Meeting

Permitted Unit: $100-\mathrm{N}$ Basin Water Processing in the 200 Area Effluent Treatment Facility

Issuance Date: June 1996

Expiration Date: NA

Need for Headquarters' Action

(for permit renewals or new permits)
Yes ( ) No (X)

If yes, HQ Program Element

Brief Summary of Relevant Information (major permit conditions, status of compliance or unusual problems):

Approval of this Notice of Construction will allow an additional waste stream (100-N Basin water) from 100-N Reactor to be treated at the 200 Area Effluent Treatment Facility. During the period covered by this Status Report, this activity proceeded with no compliance issues.

Prepared by: Westinghouse Hanford Company

Date: July 31,1996

Environmental Services 
The following information was prepared in response to requirements of DOE Order 5400.2A.

DOE Operations Office: Richland

DOE Facility: Hanford Site

Existing Permit ( ) Renewal ( ) New Permit (X)

Permit Type: Radioactive Air Emissions Program Notice of Construction -- WAC 246-247

Permitting Agency: State of Washington Department of Health

Permit Number: AIR-95-1001

Permitted Unit: 105-K East Basin Debris Removal

Issuance Date: October 3, 1995

Expiration Date: N/A

Need for Headquarters' Action

(for permit renewals or new permits)
Yes ( ) No (X)

If yes, HQ Program Element

Brief Summary of Relevant Information (major permit conditions, status of compliance or unusual problems):

Approval of this Notice of Construction allows removal of debris from the $105-\mathrm{K}$ East Basin. A description of what constitutes debris is contained in the Notice of Construction. Approval was granted, subject to the condition that the activity is conducted in accordance with descriptions contained in the application. During the period covered by this Status Report, this activity proceeded with no compliance issues.

Prepared by: Westinghouse Hanford Company

Date: July 31, 1996

Environmental Services 
The following information was prepared in response to requirements of DOE Order 5400.2A.

DOE Operations Office: Richland

DOE Facility: Hanford Site

Existing Permit ( ) Renewal ( ) New Permit (X)

Permit Type: National Emission Standard for Hazardous Air Pollutants (NESHAPs) 40 CFR 61, Subpart H

Permitting Agency: U.S. Environmental Protection Agency, Region 10

Permit Number: N/A

Permitted Unit: 105-K East Basin Debris Removal

Issuance Date: August 28, 1995

Expiration Date: N/A

Need for Headquarters' Action

(for permit renewals or new permits)
Yes ( ) No (X)

If yes, HQ Program Element

Brief Summary of Relevant Information (major permit conditions, status of compliance or unusual problems):

Approval of this permit application allows removal of debris from the 105-K East Basin. A description of what constitutes debris is contained in the Notice of Construction. Approval was granted, subject to the condition that the activity is conducted in accordance with descriptions contained in the application. During the period covered by this Status Report, this activity proceeded with no compliance issues.

Prepared by: Westinghouse Hanford Company

Date: July 31, 1996 Environmental Services 
The following information was prepared in response to requirements of DOE Order 5400.2A.

DOE Operations Office: Richland

DOE Facility: Hanford Site

Existing Permit (X) Renewal ( ) New Permit ( )

Permit Type: Radioactive Air Emissions Program Notice of Construction - WAC 246-247

Permitting Agency: State of Washington Department of Health

Permit Number: N/A

Permitted Unit: 183-H Solar Evaporation Basins

Issuance Date: April 7, 1994

Expiration Date: N/A

Need for Headquarters' Action

(for permit renewals or new permits)
Yes ( ) No (X)

If yes, HQ Program Element

Brief Summary of Relevant Information (major permit conditions, status of compliance or unusual problems):

Approval of this Notice of Construction allows the decontamination and closure of the 183-H Solar Evaporation Basins. Approval was received from the Department of Health on April 7, 1994. The decontamination activities began in May 1995 and currently are being conducted.

Prepared by: Bechtel Hanford, Inc.

Date: July 31, 1996

Regulatory Support 
The following information was prepared in response to requirements of DOE Order 5400.2A.

DOE Operations Office: Richland

DOE Facility: Hanford Site

Existing Permit (X) Renewal ( ) New Permit ( )

Permit Type: National Emission Standard for Hazardous Air Pollutants (NESHAPs) 40 CFR 61, Subpart H

Permitting Agency: U.S. Environmental Protection Agency, Region 10

Permit Number: N/A

Permitted Unit: 183-H Solar Evaporation Basins

Issuance Date: March 15, 1995

Expiration Date: N/A

Need for Headquarters' Action

(for permit renewals or new permits)
Yes ( ) No (X)

If yes, HQ Program Element

Brief Summary of Relevant Information (major permit conditions, status of compliance or unusual problems):

Approval of this application allows the decontamination and closure of the 183-H Solar Evaporation Basins. Approval was received from the EPA on March 15, 1995. The decontamination activities began in May 1995 and currently are being conducted.

Prepared by: Bechtel Hanford, Inc.

Date: July 31,1996

Regulatory Support 
The following information was prepared in response to requirements of DOE Order 5400.2A.

DOE Operations Office: Richland

DOE Facility: Hanford Site

Existing Permit ( ) Renewal ( ) New Permit (X)

Permit Type: Radioactive Air Emissions Program Notice of Construction - WAC 246-247

Permitting Agency: State of Washington Department of Health

Permit Number; Routine Technical Assistance Meeting

Permitted Unit: 183-K East Radiological Counting Lab Relocated to 1706-K East Facility

Issuance Date: April 1996

Expiration Date: NA

Need for Headquarters' Action

(for permit renewals or new permits)
Yes ( ) No (X)

If yes, HQ Program Element

Brief Summary of Relevant Information (major permit conditions, status of compliance or unusual problems):

Approval of this Notice of Construction allowed the relocation of the 183-K East Radiological Counting Laboratory to the 1705-K East Facility. Laboratory hoods located in the 1706-K East Facility do not have high-efficiency particulate air filtration but the high-efficiency particulate air filters are on the main stack. This relocation activity was completed with no compliance issues. 
The following information was prepared in response to requirements of DOE Order 5400.2A.

DOE Operations Office: Richland

DOE Facility: Hanford Site

Existing Permit ( ) Renewal ( ) New Permit (X)

Permit Type: Notice of Construction for:

General Regulations for Air Pollution Sources - WAC 173-400

Controls for New Sources of Toxic Air Pollutants - WAC 173-460

Permitting Agency: Washington State Department of Ecology

Permit Number: NWP-96-1

Permitted Unit: 200 Area Diesel Generators

Issuance Date: April 30, 1996

Expiration Date: N/A

Need for Headquarters' Action

(for permit renewals or new permits)

$$
\begin{aligned}
& \text { Yes ( ) No (X) } \\
& \text { If yes, HQ Program Element }
\end{aligned}
$$

Brief Summary of Relevant Information (major permit conditions, status of compliance or unusual problems):

Approval of this Notice of Construction allows construction and operation of two emergency diesel generators designed to provide emergency power for the 200 Areas fire protection system. A major permit condition includes limits on hours of operation and emission rates. During the period covered by this Status Report, the 200 Areas diesel generators operated with no compliance issues.

Prepared by: Westinghouse Hanford Company

Date: July 31, 1996 Environmental Services 
The following information was prepared in response to requirements of DOE Order $5400.2 \mathrm{~A}$.

DOE Operations Office: Richland

DOE Facility: Hanford Site

Existing Permit (X) Renewal ( ) New Permit ( )

Permit Type: Radioactive Air Emissions Program Notice of Construction - WAC 246-247

Permitting Agency: State of Washington Department of Health

Permit Number: AIR-95-509, AIR-93-811, and AIR-93-211

Permitted Unit: 200 Area Effluent Treatment Facility

Issuance Date: May 24, 1995, August 31, 1993, and February 22, 1993

Expiration Date: N/A

Need for Headquarters' Action

(for permit renewals or new permits)
Yes ( ) No (X)

If yes, HQ Program Element

Brief Summary of Relevant Information (major permit conditions, status of compliance or unusual problems):

Approval of this Notice of Construction allowed construction of the 200 Area Effluent Treatment Facility and approved the radionuclide air emissions control equipment. The 200 Area Effluent Treatment Facility treats and disposes of liquid effluent. The 200 Area Effluent Treatment Facility is located in the northeast corner of the 200 East Area. The 200 Area Effluent Treatment Facility originally was permitted to treat liquid effluent streams from the 242-A Evaporator and several streams from the PUREX Plant. The permit was amended (AIR-95-509) to exclude the PUREX Plant streams (reducing potential emissions) and to eliminate the requirement for continuous radionuclide emissions monitoring. During the period covered by this Status Report, the 200 Area Effluent Treatment Facility operated with no compliance issues.

Prepared by: Westinghouse Hanford Company

Date: July 31, 1996 Environmental Services 
The following information was prepared in response to requirements of DOE Order 5400.2A.

DOE Operations Office: Richland

DOE Facility: Hanford Site

Existing Permit (X) Renewal ( ) New Permit ( )

Permit Type: National Emission Standards for Hazardous Air Pollutants (NESHAPS) 40 CFR 61, Subpart H

Permitting Agency: U.S. Environmental Protection Agency, Region 10

Permit Number: N/A

Permitted Unit: 200 Area Effluent Treatment Facility

Issuance Date: March 8, 1993

Expiration Date: N/A

Need for Headquarters' Action

(for permit renewals or new permits)
Yes ( ) No (X)

If yes, HQ Program Element

Brief Summary of Relevant Information (major permit conditions, status of compliance or unusual problems):

Approval of this application allowed construction of the 200 Area Effluent Treatment Facility. The 200 Area Effluent Treatment Facility treats and disposes of liquid effluent. The 200 Area Effluent Treatment Facility is located in the northeast corner of the 200 East Area. During the period covered by this Status Report, the 200 Area Effluent Treatment Facility operated with no compliance issues.

Prepared by: Westinghouse Hanford Company

Date: July 31,1996

Environmental Services 
The following information was prepared in response to requirements of DOE Order 5400.2A.

DOE Operations Office: Richland

DOE Facility: Hanford Site

Existing Permit (X) Renewal ( ) New Permit ( )

Permit Type: Notice of Construction for:

General Regulations for Air Pollution Sources - WAC 173-400

Controls for New Sources of Toxic Air Pollutants - WAC 173-460

Permitting Agency: Washington State Department of Ecology

Permit Number: NOC-93-03

Permitted Unit: 200 Area Effluent Treatment Facility

Issuance Date: December 20, 1993

Expiration Date: N/A

Need for Headquarters' Action

(for permit renewals or new permits)
Yes ( ) No (X)

If yes, HQ Program Element

Brief Summary of Relevant Information (major permit conditions, status of compliance or unusual problems):

Approval was granted subject to the 200 Area Effluent Treatment Facility being constructed and operated in accordance with descriptions contained in the application. The 200 Area Effluent Treatment Facility treats and disposes of liquid effluent. The 200 Area Effluent Treatment Facility is located in the northeast corner of the 200 East Area. During the period covered by this Status Report, the 200 Area Effluent Treatment Facility operated with no compliance issues.

Prepared by: Westinghouse Hanford Company

Date: July 31, 1996

Environmental Services 
The following information was prepared in response to requirements of DOE Order 5400.2A.

DOE Operations Office: Richland

DOE Facility: Hanford Site

Existing Permit (X) Renewal ( ) New Permit ( )

Permit Type: Radioactive Air Emissions Program Notice of Construction - WAC 246-247

Permitting Agency: State of Washington Department of Health

Permit Number: AIR 91-NOV1

Permitted Unit: 219-S Sample Gallery to 204-AR Waste Unloading Station Waste Transfers

Issuance Date: November 12, 1991

Expiration Date: N/A

Need for Headquarters' Action

(for permit renewals or new permits)
Yes ( ) No (X)

If yes, HQ Program Element

Brief Summary of Relevant Information (major permit conditions, status of compliance or unusual problems):

Approval of this Notice of Construction allows construction for waste transfers from the 219-S Sample Gallery to the 204-AR Waste Unloading Station in accordance with descriptions contained in the application. Routine transfers of waste from the 219-S Sample Gallery in the 222-S Laboratory Complex, located in the 200 West Area, to the 204-AR Waste Unloading Station, located in the 200 East Area, are required to remove waste from the 222-S Laboratory Complex to the Double-Shell Tank System.

A Notice of Correction (AIR 96-601) was issued by the Department of Health on June 5, 1996, for failure to routinely submit operating logs for the truck transfers of liquid waste to the 204-AR Waste Unloading Station. The routine submittals are an approval condition of the permit. A response has been prepared and is scheduled to be submitted to the Department of health by August 12, 1996, the due date specified in the Notice of Correction.

Prepared by: Westinghouse Hanford Company

Date: July 31, 1996 Environmental Services 
The following information was prepared in response to requirements of DOE Order 5400.2A.

DOE Operations Office: Richland

DOE Facility: Hanford Site

Existing Permit ( ) Renewal ( ) New Permit ( X)

Permit Type: Radioactive Air Emissions Program Notice of Construction - WAC 246-247

Permitting Agency: State of Washington Department of Health

Permit Number: Routine Technical Assistance Meeting

Permitted Unit: 231-Z Building Deactivation Activities

Issuance Date: August 1995

Expiration Date: NA

Need for Headquarters' Action

(for permit renewals or new permits)

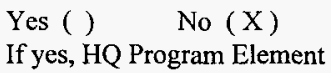

Brief Summary of Relevant Information (major permit conditions, status of compliance or unusual problems):

Approval was granted subject to the 231-Z Building Deactivation Activities for the removal of loose equipment and packaging/removal for disposal. During the period covered by this Status Report, these deactivation activities proceeded with no compliance issues.

Prepared by: Westinghouse Hanford Company

Date: July 31, 1996 
The following information was prepared in response to requirements of DOE Order 5400.2A.

DOE Operations Office: Richland

DOE Facility: Hanford Site

Existing Permit (X) Renewal ( ) New Permit ( )

Permit Type: Radioactive Air Emissions Program Notice of Construction - WAC 246-247

Permitting Agency: State of Washington Department of Health

Permit Number: AIR-95-106

Permitted Unit: 232-Z Building Modification

Issuance Date: January 24, 1995

Expiration Date: N/A

Need for Headquarters' Action

(for permit renewals or new permits)
Yes ( ) No (X)

If yes, HQ Program Element

Brief Summary of Relevant Information (major permit conditions, status of compliance or unusual problems):

Approval of this Notice of Construction allows for the cleanup and removal of contaminated portions of the 232-Z Building in accordance with the conditions and descriptions contained in the application. The main purpose of the modification is to reduce the potential for a significant release in case of a damaging seismic event. A secondary benefit reduces exposure to personnel during routine work and future decontamination and demolition activities. The first cleanup campaign was approved on February 28, 1994 (AIR-94-217), and completed in July 1994. Additional cleanup was required so a modification to the application was resubmitted and approved on January 24, 1995. During the period covered by this Status Report, the 232-Z Building modification proceeded with no compliance issues.

Prepared by: Westinghouse Hanford Company

Date: July 31,1996

Environmental Services 
The following information was prepared in response to requirements of DOE Order 5400.2A.

DOE Operations Office: Richland

DOE Facility: Hanford Site

Existing Permit (X) Renewal ( ) New Permit ( )

Permit Type: National Emission Standard for Hazardous Air Pollutants (NESHAPs) 40 CFR 61, Subpart H

Permitting Agency: U.S. Environmental Protection Agency, Region 10

Permit Number: N/A

Permitted Unit: 232-Z Building Modification

Issuance Date: March 9, 1994

Expiration Date: N/A

Need for Headquarters' Action

(for permit renewals or new permits)
Yes ( ) No (X)

If yes, HQ Program Element

Brief Summary of Relevant Information (major permit conditions, status of compliance or unusual problems):

Approval of this application allows for the cleanup and removal of contaminated portions of the 232-Z Building in accordance with the conditions and descriptions contained in the application. The main purpose of the modification is to reduce the potential for a significant release in case of a damaging seismic event. A secondary benefit reduces exposure to personnel during routine work and future decontamination and demolition activities. The first cleanup campaign was approved on March 3, 1994, and completed in July 1994. Additional cleanup was required so a modification to the application was resubmitted and approved on February 1, 1995. During the period covered by this Status Report, the $232-Z$ Building modification proceeded with no compliance issues.

Prepared by: Westinghouse Hanford Company

Date: July 31,1996

Environmental Services 
The following information was prepared in response to requirements of DOE Order 5400.2A.

DOE Operations Office: Richland

DOE Facility: Hanford Site

Existing Permit (X) Renewal ( ) New Permit ( )

Permit Type: Radioactive Air Emissions Program Notice of Construction - WAC 246-247

Permitting Agency: State of Washington Department of Health

Permit Number: AIR 94-1214

Permitted Unit: 233-S Plutonium Concentration Facility

Issuance Date: December 15, 1994

Expiration Date: June 15, 1996

Need for Headquarters' Action

(for permit renewals or new permits)

Yes ( ) No (X)

If yes, HQ Program Element

Brief Summary of Relevant Information (major permit conditions, status of compliance or unusual problems):

Approval of this Notice of Construction allows the decommissioning of the 233-S Plutonium Concentration Facility. Approval was received on December 15, 1994. After obtaining this permit, the 233-S Plutonium Concentration Facility decommissioning project was placed under CERCLA authority. Under CERCLA, permitting documentation is not required.

Prepared by: Bechtel Hanford, Inc.

Date: July 31,1996

Regulatory Support 
The following information was prepared in response to requirements of DOE Order 5400.2A.

DOE Operations Office: Richland

DOE Facility: Hanford Site

Existing Permit (X) Renewal ( ) New Permit ( )

Permit Type: National Emission Standard for Hazardous Air Pollutants (NESHAPs) --. 40 CFR 61, Subpart H

Permitting Agency: U.S. Environmental Protection Agency, Region 10

Permit Number: N/A, CERCLA Activity

Permitted Unit: 233-S Plutonium Concentration Facility

Issuance Date: November 28, 1994

Expiration Date: N/A

Need for Headquarters' Action

(for permit renewals or new permits)

\author{
Yes ( ) No (X) \\ If yes, HQ Program Element
}

Brief Summary of Relevant Information (major permit conditions, status of compliance or unusual problems):

Approval of this application allows the decommissioning of the 233-S Plutonium Concentration Facility. Approval was received on November 28, 1994. After obtaining this approval, the 233-S Plutonium Concentration Facility decommissioning project was placed under CERCLA authority. Under CERCLA, permitting documentation is not required.

Prepared by: Bechtel Hanford, Inc.

Date: July 31, 1996

Regulatory Support 
The following information was prepared in response to requirements of DOE Order 5400.2A.

DOE Operations Office: Richland

DOE Facility: Hanford Site

Existing Permit ( ) Renewal ( ) New Permit (X)

Permit Type: Radioactive Air Emissions Program Notice of Construction - WAC 246-247

Permitting Agency: State of Washington Department of Health

Permit Number: Routine Technical Assistance Meeting

Permitted Unit: $234-5-Z$ Muffle Furnaces

Issuance Date: August 1995

Expiration Date: NA

Need for Headquarters' Action

(for permit renewals or new permits)
Yes ( ) No (X)

If yes, HQ Program Element

Brief Summary of Relevant Information (major permit conditions, status of compliance or unusual problems):

Approval of this Notice of Construction allows the installation and operation of two additional muffle furnaces at 234-5-Z. The startup of two muffle furnaces in 1994 showed no increase in measurable emissions. No measurable increase is expected due to startup of six additional furnaces (three in each of two gloveboxes). During the period covered by this Status Report, the 234-5-Z Muffle Furnaces operated with no compliance issues.

Prepared by: Westinghouse Hanford Company

Date: July 31, 1996

Environmental Services 
The following information was prepared in response to requirements of DOE Order $5400.2 \mathrm{~A}$.

DOE Operations Office: Richland

DOE Facility: Hanford Site

Existing Permit (X) Renewal ( ) New Permit ( )

Permit Type: Radioactive Air Emissions Program Notice of Construction - WAC 246-247

Permitting Agency: State of Washington Department of Health

Permit Number: AIR 94-913

Permitted Unit: 244-CR Vault Double-Contained Receiver Tank

Issuance Date: September 15, 1994

Expiration Date: N/A

Need for Headquarters' Action

(for permit renewals or new permits)

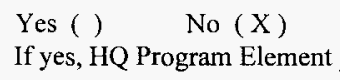

Brief Summary of Relevant Information (major permit conditions, status of compliance or unusual problems):

Approval of this Notice of Construction was granted subject to the 244-CR Vault double-contained receiver tank operating in accordance with descriptions contained in the application. During the period covered by this Status Report, the 244-CR Vault double-contained receiver tank operated with no compliance issues.

Prepared by: Environmental Services

Date: July 31,1996 
The following information was prepared in response to requirements of DOE Order 5400.2A.

DOE Operations Office: Richland

DOE Facility: Hanford Site

Existing Permit (X) Renewal ( ) New Permit ( )

Permit Type: Radioactive Air Emissions Program Notice of Construction - WAC 246-247

Permitting Agency: State of Washington Department of Health

Permit Number: N/A

Permitted Unit: 300 Area Treated Effluent Disposal Facility, Project L-045H

Issuance Date: February 3, 1993

Expiration Date: N/A

Need for Headquarters' Action

(for permit renewals or new permits)

Yes ( ) No (X)

If yes, HQ Program Element

Brief Summary of Relevant Information (major permit conditions, status of compliance or unusual problems):

Approval of this Notice of Construction allows construction of the 300 Area Treated Effluent Disposal Facility (Project L-045H) and approved the radionuclide air emissions control equipment. Project L-045H is designed to treat and dispose of the process effluent from industrial and research operations in the 300 Area to the Columbia River. No revisions of the Radioactive Air Emissions Program Notice of Construction have been submitted.

Prepared by: Westinghouse Hanford Company

Date: July 31, 1996

Environmental Services 
The following information was prepared in response to requirements of DOE Order 5400.2A.

DOE Operations Office: Richland

DOE Facility: Hanford Site

Existing Permit ( ) Renewal ( ) New Permit (X)

Permit Type: Radioactive Air Emissions Program Notice of Construction - WAC 246-247

Permitting Agency: State of Washington Department of Health

Permit Number: Routine Technical Assistance Meeting

Permitted Unit: 303-M Building Stabilization

Issuance Date: May 1996

Expiration Date: NA

Need for Headquarters' Action

(for permit renewals or new permits)

\section{Yes ( ) No ( $\mathrm{X})$}

If yes, HQ Program Element

Brief Summary of Relevant Information (major permit conditions, status of compliance or unusual problems):

Approval of this Notice of Construction allows stabilization activities within the 303-M Building (e.g., applying fixatives and decontamination). The 303-M Building was last used in 1987. During the period covered by this Status Report, stabilization activities proceeded with no compliance issues.

Prepared by: Westinghouse Hanford Company

Date: July 31,1996 Environmental Services 
The following information was prepared in response to requirements of DOE Order $5400.2 \mathrm{~A}$.

DOE Operations Office: Richland

DOE Facility: Hanford Site

Existing Permit ( ) Renewal ( ) New Permit (X)

Permit Type: Radioactive Air Emissions Program Notice of Construction - WAC 246-247

Permitting Agency: State of Washington Department of Health

Permit Number: Routine Technical Assistance Meeting

Permitted Unit: 304 Building Stabilization

Issuance Date: May 1996

Expiration Date: NA

Need for Headquarters' Action

Yes ( ) No (X)

(for permit renewals or new permits)

If yes, HQ Program Element

Brief Summary of Relevant Information (major permit conditions, status of compliance or unusual problems):

Approval of this Notice of Construction allows stabilization activities within the 304 Building. During stabilization activities, continuous air monitors are operational. During the period covered by this Status Report, this activity proceeded with no compliance issues.

Prepared by: Westinghouse Hanford Company

Date: July 31, 1996

Environmental Services 
The following information was prepared in response to requirements of DOE Order 5400.2A.

DOE Operations Office: Richland

DOE Facility: Hanford Site

Existing Permit ( ) Renewal ( ) New Permit (X)

Permit Type: Radioactive Air Emissions Program Notice of Construction - WAC 246-247

Permitting Agency: State of Washington Department of Health

Permit Number: AIR-95-811

Permitted Unit: 305-B Storage Facility

Issuance Date: August 25, 1995

Expiration Date: N/A

Need for Headquarters' Action

Yes ( ) No ( $\mathrm{X}$ )

(for permit renewals or new permits)

If yes, HQ Program Element

Brief Summary of Relevant Information (major permit conditions, status of compliance or unusual problems):

Approval of this Notice of Construction allowed the construction of a fume hood in the 305-B Storage Facility for waste sampling and repackaging activities and approved the radionuclide air emissions control equipment. On August 25, 1995, an approval letter was received from the Department of Health. The construction of the fume hood in the 305-B Storage Facility is complete and operational.

Prepared by: Pacific Northwest National Laboratory

Date: July 31, 1996

Environmental Compliance 
The following information was prepared in response to requirements of DOE Order 5400.2A.

DOE Operations Office: Richland

DOE Facility: Hanford Site

Existing Permit ( ) Renewal ( ) New Permit ( X)

Permit Type: Radioactive Air Emissions Program Notice of Construction - WAC 246-247

Permitting Agency: State of Washington Department of Health

Permit Number: Routine Technical Assistance Meeting

Permitted Unit: 306-E Building High-Efficiency Particulate Air Filter Testing Methods

Issuance Date: December 1995

Expiration Date: NA

Need for Headquarters' Action

(for permit renewals or new permits)
Yes ( ) No ( $\mathrm{X}$ )

If yes, HQ Program Element

Brief Summary of Relevant Information (major permit conditions, status of compliance or unusual problems):

Approval of this Notice of Construction allows for alternate methods of testing to be used to test the high-efficiency particulate air filtration efficiency at the building. The filter testing is an ongoing activity. During the period covered by this Status Report, these activities proceeded with no compliance issues.

Prepared by: Westinghouse Hanford Company

Date: July 31, 1996

Environmental Services 
The following information was prepared in response to requirements of DOE Order 5400.2A.

DOE Operations Office: Richland

DOE Facility: Hanford Site

Existing Permit ( ) Renewal ( ) New Permit (X)

Permit Type: Radioactive Air Emissions Program Notice of Construction - WAC 246-247

Permitting Agency: State of Washington Department of Health

Permit Number: Routine Technical Assistance Meeting

Permitted Unit: 306-E Restart Facility Stack

Issuance Date: November 1995

Expiration Date: NA

Need for Headquarters' Action

(for permit renewals or new permits)
Yes ( ) No (X)

If yes, HQ Program Element

Brief Summary of Relevant Information (major permit conditions, status of compliance or unusual problems):

Approval of this Notice of Construction allows the restart of laboratory activities in the 306-E Building that had previously been conducted in the 377 Building. Only small-scale experiments of a laboratory nature were planned. The 306-E stack is not operational, and if the stack is not restarted within 18 months of this permit approval, a closure notice will be prepared.

Prepared by: Westinghouse Hanford Company

Date: July 31, 1996 Environmental Services 
The following information was prepared in response to requirements of DOE Order 5400.2A.

DOE Operations Office: Richland

DOE Facility: Hanford Site

Existing Permit ( ) Renewal ( ) New Permit (X)

Permit Type: Radioactive Air Emissions Program Notice of Construction - WAC 246-247

Permitting Agency: State of Washington Department of Health

Permit Number: Routine Technical Assistance Meeting

Permitted Unit: 313 Facility Uranium-Bearing System Removal

Issuance Date: November 1995

Expiration Date: NA

Need for Headquarters' Action

$$
\text { Yes ( ) No (X) }
$$

(for permit renewals or new permits)

If yes, HQ Program Element

Brief Summary of Relevant Information (major permit conditions, status of compliance or unusual problems):

Approval of this Notice of Construction allows the removal of residual uranium-bearing material from a system of tanks and valves in the 313 Building as a part of deactivation activities. The uranium source term is well characterized for the cleanout activity. During the period covered by this Status Report, this activity proceeded with no compliance issues.

Prepared by: Westinghouse Hanford Company

Date: July 31, 1996 Environmental Services 
The following information was prepared in response to requirements of DOE Order 5400.2A.

DOE Operations Office: Richland

DOE Facility: Hanford Site

Existing Permit ( ) Renewal ( ) New Permit (X)

Permit Type: Radioactive Air Emissions Program Notice of Construction - WAC 246-247

Permitting Agency: State of Washington Department of Health

Permit Number: Routine Technical Assistance Meeting

Permitted Unit: 313 Facility Residue Removal

Issuance Date: December 1995

Expiration Date: NA

Need for Headquarters' Action

(for permit renewals or new permits)
Yes ( ) No (X)

If yes, HQ Program Element

Brief Summary of Relevant Information (major permit conditions, status of compliance or unusual problems):

Approval of this Notice of Construction allows the removal of residue and debris from floor troughs in the 313 Building. This facility is one of several passively ventilated, unfiltered buildings scheduled for cleanout before deactivation. The residue and debris have been removed; however, sampling activities associated with cleanout are ongoing. During the period covered by this Status Report, this activity proceeded with no compliance issues.

Prepared by: Westinghouse Hanford Company

Date: July 31, 1996 Environmental Services 
The following information was prepared in response to requirements of DOE Order 5400.2A.

DOE Operations Office: Richland

DOE Facility: Hanford Site

Existing Permit ( ) Renewal ( ) New Permit (X)

Permit Type: Radioactive Air Emissions Program Notice of Construction - WAC 246-247

Permitting Agency: State of Washington Department of Health

Permit Number: Routine Technical Assistance Meeting

Permitted Unit: 318 Building High-Efficiency Particulate Air Filter Removal

Issuance Date: September 1995

Expiration Date: NA

Need for Headquarters' Action

(for permit renewals or new permits)
Yes ( ) No (X)

If yes, HQ Program Element

Brief Summary of Relevant Information (major permit conditions, status of compliance or unusual problems):

Approval of this Notice of Construction allowed the removal of high-efficiency particulate air filtration in the 318 Building. Approval was received from the Department of Health in September 1995 . This activity was completed with no compliance issues.

Prepared by: Pacific Northwest National Laboratory

Date: July 31, 1996

Environmental Compliance 
The following information was prepared in response to requirements of DOE Order 5400.2A.

DOE Operations Office: Richland

DOE Facility: Hanford Site

Existing Permit ( ) Renewal ( ) New Permit (X)

Permit Type: Radioactive Air Emissions Program Notice of Construction - WAC 246-247

Permitting Agency: State of Washington Department of Health

Permit Number: Routine Technical Assistance Meeting

Permitted Unit: 324 Building Hood Installation

Issuance Date: September 1995

Expiration Date: NA

Need for Headquarters' Action

(for permit renewals or new permits)

\section{Yes ( ) No ( X)}

If yes, HQ Program Element

Brief Summary of Relevant Information (major permit conditions, status of compliance or unusual problems):

Approval of this Notice of Construction allowed the installation of a hood in the 324 Building. The hood will be used to conduct soil melting experiments using a plasma arc for removal of loose equipment and packaging/removal for disposal. This activity was completed with no compliance issues.

Prepared by: Pacific Northwest National Laboratory

Date: July 31, 1996

Environmental Compliance 
The following information was prepared in response to requirements of DOE Order $5400.2 \mathrm{~A}$.

DOE Operations Office: Richland

DOE Facility: Hanford Site

Existing Permit ( ) Renewal ( ) New Permit (X)

Permit Type: Radioactive Air Emissions Program Notice of Construction - WAC 246-247

Permitting Agency: State of Washington Department of Health

Permit Number: Routine Technical Assistance Meeting

Permitted Unit: 331 High-Efficiency Particulate Air Filter Bank Removal

Issuance Date: May 1996

Expiration Date: NA

Need for Headquarters' Action

(for permit renewals or new permits)

Yes ( ) No (X)

If yes, HQ Program Element

Brief Summary of Relevant Information (major permit conditions, status of compliance or unusual problems):

Approval of this Notice of Construction allows the removal of a high-efficiency particulate air filter bank from the 331 Building. The high-efficiency particulate air filter replacement was approved in May 1996. During the period covered by this Status Report, this activity proceeded with no compliance issues.

Prepared by: Pacific Northwest National Laboratory

Date: July 31,1996

Environmental Compliance 
The following information was prepared in response to requirements of DOE Order 5400.2A.

DOE Operations Office: Richland

DOE Facility: Hanford Site

Existing Permit ( ) Renewal ( ) New Permit (X)

Permit Type: Radioactive Air Emissions Program Notice of Construction - WAC 246-247

Permitting Agency: State of Washington Department of Health

Permit Number: Routine Technical Assistance Meeting

Permitted Unit: 340-DECON Stack Pollution Control Equipment Modification

Issuance Date: June 1996

Expiration Date: NA

Need for Headquarters' Action

(for permit renewals or new permits)
Yes ( ) No (X)

If yes, HQ Program Element

Brief Summary of Relevant Information (major permit conditions, status of compliance or unusual problems):

Approval of this Notice of Construction allows the modification to the 340-DECON stack. The primary (initial) bank of three high-efficiency particulate air equivalent filters (in series) is to be replaced with an industrial rated high-efficiency particulate air filter (not testable). One condition before approving the request was that "reduction from three stages high-efficiency particulate air to two stages with a prefilter is in line with the as low as reasonably achievable control technology standard applicable for nondesignated stacks." During the period covered by this Status Report, this activity proceeded with no compliance issues.

Prepared by: Westinghouse Hanford Company

Date: July 31, 1996 Environmental Services 
The following information was prepared in response to requirements of DOE Order $5400.2 \mathrm{~A}$.

DOE Operations Office: Richland

DOE Facility: Hanford Site

Existing Permit ( ) Renewal ( ) New Permit (X)

Permit Type: Radioactive Air Emissions Program Notice of Construction - WAC 246-247

Permitting Agency: State of Washington Department of Health

Permit Number: AIR 95-801

Permitted Unit: 1303-N Fuel Spacer Silos

Issuance Date: August 3, 1995

Expiration Date: N/A

Need for Headquarters' Action

(for permit renewals or new permits)
Yes ( ) No (X)

If yes, HQ Program Element

Brief Summary of Relevant Information (major permit conditions, status of compliance or unusual problems):

Approval of this Notice of Construction allowed the removal of spacers from the 1303-N Fuel Spacer Silos located in the 100-N Area using approved radionuclide air emissions control equipment. Removal activities included work in preparation for final remediation of the 1303-N Fuel Spacer Silos. Approval was received on August 3, 1995. The project was completed on August 31, 1995.

Prepared by: Bechtel Hanford, Inc.

Date: July 31, 1996

Regulatory Support 
The following information was prepared in response to requirements of DOE Order 5400.2A.

DOE Operations Office: Richland

DOE Facility: Hanford Site

Existing Permit (X) Renewal ( ) New Permit ( )

Permit Type: National Emission Standard for Hazardous Air Pollutants (NESHAPs) 40 CFR 61, Subpart H

Permitting Agency: U.S. Environmental Protection Agency, Region 10

Permit Number: N/A

Permitted Unit: 1303-N Fuel Spacer Silos

Issuance Date: June 5, 1995

Expiration Date: N/A

Need for Headquarters' Action

(for permit renewals or new permits)

\section{Yes ( ) No (X)}

If yes, HQ Program Element

Brief Summary of Relevant Information (major permit conditions, status of compliance or unusual problems):

Approval of this application allowed for the removal of spacers from the 1303-N Fuel Spacer Silos located in the 100-N Area using approved radionuclide air emissions control equipment. Removal activities included work in preparation for final remediation of the 1303-N Fuel Spacer Silos. Approval was received on June 5, 1995. The project was completed on August 31, 1995.

Prepared by: Bechtel Hanford, Inc.

Date: July 31,1996

Regulatory Support 
The following information was prepared in response to requirements of DOE Order 5400.2A.

DOE Operations Office: Richland

DOE Facility: Hanford Site

Existing Permit ( ) Renewal ( ) New Permit (X)

Permit Type: Radioactive Air Emissions Program Notice of Construction - WAC 246-247

Permitting Agency: State of Washington Department of Health

Permit Number: AIR-96-604

Permitted Unit: Applied Chemistry, 325 Building

Issuance Date: June 7, 1996

Expiration Date: N/A

Need for Headquarters' Action

(for permit renewals or new permits)
Yes ( ) No (X)

If yes, HQ Program Element

Brief Summary of Relevant Information (major permit conditions, status of compliance or unusual problems):

Approval of this Notice of Construction allows research to be conducted on special nuclear materials disposition and low-level waste vitrification. The research includes slurry and powder feeds, melting, quenching, and annealing of plutonium containing glasses. Approval was received on June 7,1996 . The preparation for this research work is ongoing.

Prepared by: Pacific Northwest National Laboratory

Date: July 31, 1996

Environmental Compliance 
The following information was prepared in response to requirements of DOE Order 5400.2A.

DOE Operations Office: Richland

DOE Facility: Hanford Site

Existing Permit ( ) Renewal ( ) New Permit (X)

Permit Type: National Emission Standards for Hazardous Air Pollutants (NESHAPs) 40 CFR 61, Subpart H

Permitting Agency: U.S. Environmental Protection Agency, Region 10

Permit Number: N/A

Permitted Unit: Applied Chemistry, 325 Building

Issuance Date: May 7, 1996

Expiration Date: N/A

Need for Headquarters' Action

(for permit renewals or new permits)

\section{Yes ( ) No (X)}

If yes, HQ Program Element

Brief Summary of Relevant Information (major permit conditions, status of compliance or unusual problems):

Approval of this Notice of Construction allows research to be conducted on special nuclear materials disposition and low-level waste vitrification. The research includes slurry and powder feeds, melting, quenching, and annealing of plutonium containing glasses. On May 7, 1996, an approval letter was received. The preparation for this research work is ongoing.

Prepared by: Pacific Northwest National Laboratory

Date: July 31,1996 Environmental Compliance 
The following information was prepared in response to requirements of DOE Order 5400.2A.

DOE Operations Office: Richland

DOE Facility: Hanford Site

Existing Permit ( ) Renewal ( ) New Permit (X)

Permit Type: Radioactive Air Emissions Program Notice of Construction - WAC 246-247

Permitting Agency: State of Washington Department of Health

Permit Number: Routine Technical Assistance Meeting

Permitted Unit: B Plant Canyon Exhaust Tunnel and D-Cell Video Inspection and Dose Measurements

Issuance Date: July 1996

Expiration Date: NA

Need for Headquarters' Action

(for permit renewals or new permits)
Yes ( ) No ( $\mathrm{X}$ )

If yes, HQ Program Element

Brief Summary of Relevant Information (major permit conditions, status of compliance or unusual problems):

Approval of this Notice of Construction allows video inspection and dose measurements of the B Plant canyon exhaust tunnel and D-Cell. During the period covered by this Status Report, the inspection and measurement activities proceeded with no compliance issues.

Prepared by: Westinghouse Hanford Company

Date: July 31, 1996

Environmental Service 
The following information was prepared in response to requirements of DOE Order 5400.2A.

DOE Operations Office: Richland

DOE Facility: Hanford Site

Existing Permit ( ) Renewal ( ) New Permit (X)

Permit Type: Radioactive Air Emissions Program Notice of Construction — WAC 246-247

Permitting Agency: State of Washington Department of Health

Permit Number: Routine Technical Assistance Meeting

Permitted Unit: B Plant Transition Activities

Issuance Date: April 1996

Expiration Date: NA

Need for Headquarters' Action

(for permit renewals or new permits)

$$
\begin{aligned}
& \text { Yes ( ) No (X) } \\
& \text { If yes, HQ Program Element }
\end{aligned}
$$

Brief Summary of Relevant Information (major permit conditions, status of compliance or unusual problems):

Approval of this Notice of Construction allows activities to support the transition of B Plant to a deactivated status. This includes activities such as soap and water cleaning of the canyon deck. During the period covered by this Status Report, these transition activities proceeded with no compliance issues.

Prepared by: Westinghouse Hanford Company

Date: July 31, 1996

Environmental Services 
The following information was prepared in response to requirements of DOE Order 5400.2A.

DOE Operations Office: Richland

DOE Facility: Hanford Site

Existing Permit ( ) Renewal ( ) New Permit (X)

Permit Type: Radioactive Air Emissions Program Notice of Construction - WAC 246-247

Permitting Agency: State of Washington Department of Health

Permit Number: Routine Technical Assistance Meeting

Permitted Unit: B Plant Vacuum Loader (The Guzzler)

Issuance Date: August 1995

Expiration Date: NA

Need for Headquarters' Action

(for permit renewals or new permits)
Yes ( ) No (X)

If yes, HQ Program Element

Brief Summary of Relevant Information (major permit conditions, status of compliance or unusual problems):

Approval of this Notice of Construction allowed the washing out of 11,000 linear feet of process sewer pipe in the 300 Area. This washing out was accomplished without the use of the 'guzzler' vacuum. The project was completed with no compliance issues.

Prepared by: Westinghouse Hanford Company

Date: July 31, 1996 Environmental Services 
The following information was prepared in response to requirements of DOE Order 5400.2A.

DOE Operations Office: Richland

DOE Facility: Hanford Site

Existing Permit (X) Renewal ( ) New Permit ( )

Permit Type: National Emission Standard for Hazardous Air Poliutants (NESHAPs) 40 CFR 61, Subpart H

Permitting Agency: U.S. Environmental Protection Agency, Region 10

Permit Number: N/A

Permitted Unit: B Plant Vacuum Loader (The Guzzler)

Issuance Date: August 3, 1994

Expiration Date: February 1996

Need for Headquarters' Action

(for permit renewals or new permits)
Yes ( ) No ( $X$ )

If yes, HQ Program Element

Brief Summary of Relevant Information (major permit conditions, status of compliance or unusual problems):

Approval of this application allows the use of the B Plant vacuum loader in accordance with descriptions contained in the application. The B Plant vacuum loader is a truck mounted unit capable of vacuuming and containing contaminated soils.

Prepared by: Westinghouse Hanford Company

Date: July 31,1996

Environmental Services 
The following information was prepared in response to requirements of DOE Order 5400.2A.

DOE Operations Office: Richland

DOE Facility: Hanford Site

Existing Permit ( ) Renewal ( ) New Permit (X)

Permit Type: Radioactive Air Emissions Program Notice of Construction -- WAC 246-247

Permitting Agency: State of Washington Department of Health

Permit Number: AIR-96-103

Permitted Unit: Canister Storage Building Phase I

Issuance Date: January 11, 1996

Expiration Date: N/A

Need for Headquarters' Action

(for permit renewals or new permits)
Yes ( ) No (X)

If yes, HQ Program Element

Brief Summary of Relevant Information (major permit conditions, status of compliance or unusual problems):

Approval of this application will allow construction of the Phase I of the Canister Storage Building in accordance with the conditions and descriptions contained in the application. Phase $I$ is defined as constructing the substructure, including, but not limited to, pouring the concrete for the floor and construction of exterior walls. A Phase II application must be approved before installation of the process equipment and emissions control equipment. During the period covered by this Status Report, these activities proceeded with no compliance issues.

Prepared by: Westinghouse Hanford Company

Date: July 31, 1996

Environmental Services 
The following information was prepared in response to requirements of DOE Order 5400.2A.

DOE Operations Office: Richland

DOE Facility: Hanford Site

Existing Permit ( ) Renewal ( ) New Permit (X)

Permit Type: National Emission Standard for Hazardous Air Pollutants (NESHAPs) 40 CFR 61, Subpart $H$

Permitting Agency: U.S. Environmental Protection Agency, Region 10

Permit Number: N/A

Permitted Unit: Canister Storage Building Phase I

Issuance Date: TBD

Expiration Date: N/A

Need for Headquarters' Action

(for permit renewals or new permits)

\section{Yes ( ) No (X)}

If yes, HQ Program Element

Brief Summary of Relevant Information (major permit conditions, status of compliance or unusual problems):

Approval of this application allows construction of the Phase I of the Canister Storage Building in accordance with the conditions and descriptions contained in the application. Phase I is defined as constructing the substructure, including, but not limited to pouring the concrete for the floor and construction of exterior walls. A Phase Il application must be approved before installation of the process equipment and emissions control equipment. During the period covered by this Status Report, these activities proceeded with no compliance issues.

Prepared by: Westinghouse Hanford Company

Date: July 31, 1996

Environmental Services 
The following information was prepared in response to requirements of DOE Order 5400.2A.

DOE Operations Office: Richland

DOE Facility: Hanford Site

Existing Permit ( ) Renewal ( ) New Permit (X)

Permit Type: Notice of Construction for:

General Regulations for Air Pollution Sources - WAC 173-400

Permitting Agency: Washington State Department of Ecology

Permit Number: AIR-95-1008 and AIR-95-1009

Permitted Unit: Central Waste Complex and Enhanced Radioactive and Mixed Waste Storage, Phase IV

Issuance Date: October 24, 1995

Expiration Date: N/A

Need for Headquarters' Action

(for permit renewals or new permits)

\section{Yes ( ) No $(\mathrm{X})$}

If yes, HQ Program Element

Brief Summary of Relevant Information (major permit conditions, status of compliance or unusual problems):

Approval of this application allows construction of the Enhanced and Radioactive Mixed Waste Storage Facility, Phase IV. Phase IV will provide additional mixed waste storage capacity in three new buildings. The Notice of Construction allows additional storage of mixed and radioactive waste in the existing Central Waste Complex. During the period covered by this Status Report, these activities proceeded with no compliance issues.

Prepared by: Westinghouse Hanford Company

Date: July 31, 1996

Environmental Services 
The following information was prepared in response to requirements of DOE Order 5400.2A.

DOE Operations Office: Richland

DOE Facility: Hanford Site

Existing Permit (X) Renewal ( ) New Permit ( )

Permit Type: Radioactive Air Emissions Program Notice of Construction - WAC 246-247

Permitting Agency: State of Washington Department of Health

Permit Number: N/A

Permitted Unit: Chemical Sciences Laboratory, 329 Building

Issuance Date: February 24, 1995

Expiration Date: N/A

Need for Headquarters' Action

(for permit renewals or new permits)
Yes ( ) No ( $\mathrm{X}$ )

If yes, HQ Program Element

Brief Summary of Relevant Information (major permit conditions, status of compliance or unusual problems):

Approval of this Notice of Construction and other approvals allows for the renovation of the Chemical Sciences Laboratory (329 Building) in the 300 Area. The renovation includes modernizing the laboratories and ventilation system to consolidate four emission points into a single exhaust stack. On February 4, 1996, an approval letter was received from the Department of Health. The renovation of the Chemical Sciences Laboratory is complete and the 329 Building is operational.

Prepared by: Pacific Northwest National Laboratory

Date: July 31, 1996 Environmental Compliance 
The following information was prepared in response to requirements of DOE Order 5400.2A.

DOE Operations Office: Richland

DOE Facility: Hanford Site

Existing Permit (X) Renewal ( ) New Permit ( )

Permit Type: National Emission Standard for Hazardous Air Pollutants (NESHAPs) 40 CFR 61, Subpart H

Permitting Agency: U.S. Environmental Protection Agency, Region 10

Permit Number: N/A

Permitted Unit: Chemical Sciences Laboratory, 329 Building

Issuance Date: March 1, 1995

Expiration Date: N/A

Need for Headquarters' Action

(for permit renewals or new permits)
Yes ( ) No (X)

If yes, HQ Program Element

Brief Summary of Relevant Information (major permit conditions, status of compliance or unusual problems):

Approval of this application allows for the renovation of the Chemical Sciences Laboratory (329 Building) in the 300 Area. The renovation includes modernizing the laboratories and ventilation system to consolidate four emission points into a single exhaust stack. On March 1, 1996, an approval letter was received from the EPA. The renovation of the Chemical Sciences Laboratory is complete and the 329 Building is operational.

Prepared by: Pacific Northwest National Laboratory

Date: July 31, 1996

Environmental Compliance 
The following information was prepared in response to requirements of DOE Order 5400.2A.

DOE Operations Office: Richland

DOE Facility: Hanford Site

Existing Permit ( ) Renewal ( ) New Permit (X)

Permit Type: Notice of Construction for:

General Regulations for Air Pollution Sources - WAC 173-400

Permitting Agency: Washington State Department of Ecology

Permit Number: NWP-95-329/300A

Permitted Unit: Chemical Sciences Laboratory, 329 Building

Issuance Date: June 5, 1996

Expiration Date: N/A

Need for Headquarters' Action

(for permit renewals or new permits)
Yes ( ) No (X)

If yes, HQ Program Element

Brief Summary of Relevant Information (major permit conditions, status of compliance or unusual problems):

Approval of this Notice of Construction allows the renovation of the Chemical Sciences Laboratory (329 Building) in the 300 Area. The renovation included modernizing the laboratories and ventilation system to consolidate four emission points into a single exhaust stack. On June 5, 1996, an approval letter was received from Ecology, with emission limits for opacity and volatile organic compound compliance through a source test. The renovation of the Chemical Sciences Laboratory is complete and the 329 Building is operational.

Prepared by: Pacific Northwest National Laboratory

Date: July 31,1996 Environmental Compliance 
The following information was prepared in response to requirements of DOE Order $5400.2 \mathrm{~A}$.

DOE Operations Office: Richland

DOE Facility: Hanford Site

Existing Permit (X) Renewal ( ) New Permit ( )

Permit Type: Notice of Construction for:

General Regulations for Air Pollution Sources - WAC 173-400

Controls for New Sources of Toxic Air Pollutants - WAC 173-460

Permitting Agency: Washington State Department of Ecology

Permit Number: NWP-95-1300N EDB

Permitted Unit: Emergency Dump Basin

Issuance Date: July 14, 1995

Expiration Date: N/A

Need for Headquarters' Action

(for permit renewals or new permits)
Yes ( ) No $(X)$

If yes, HQ Program Element

Brief Summary of Relevant Information (major permit conditions, status of compliance or unusual problems):

Approval of this Notice of Construction allows the Environmental Restoration Contractor to remediate the Emergency Dump Basin. The project began on July 9, 1996 and work currently is being conducted. During the period covered by this Status Report, the Emergency Dump Basin remediation activities proceeded with no compliance issues.

Prepared by: Bechtel Hanford, Inc

Date: July 31, 1996

Regulatory Support 
The following information was prepared in response to requirements of DOE Order 5400.2A.

DOE Operations Office: Richland

DOE Facility: Hanford Site

Existing Permit (X) Renewal ( ) New Permit ( )

Permit Type: Radioactive Air Emissions Program Notice of Construction --. WAC 246-247

Permitting Agency: State of Washington Department of Health

Permit Number: AIR 95-407

Permitted Unit: Environmental Analytical Laboratory

Issuance Date: April 13, 1995

Expiration Date: N/A

Need for Headquarters' Action Yes ( ) No ( X)

(for permit renewals or new permits) If yes, HQ Program Element

Brief Summary of Relevant Information (major permit conditions, status of compliance or unusual problems):

Approval of this Notice of Construction allows the Environmental Analytical Laboratory to perform timely radiological screening and analyses. Approval was received from the Department of Health on April 27, 1995. Analysis activities began in May 1995, and are continuing.

Prepared by: Bechtel Hanford, Inc.

Date: July 31, 1996

Regulatory Support 
The following information was prepared in response to requirements of DOE Order 5400.2A.

DOE Operations Office: Richland

DOE Facility: Hanford Site

Existing Permit (X) Renewal ( ) New Permit ( )

Permit Type: National Emission Standard for Hazardous Air Pollutants (NESHAPs) - 40 CFR 61, Subpart H

Permitting Agency: U.S. Environmental Protection Agency, Region 10

Permit Number: N/A

Permitted Unit: Environmental Analytical Laboratory

Issuance Date: April 27, 1995

Expiration Date: N/A

Need for Headquarters' Action

(for permit renewals or new permits)
Yes ( ) No ( $\mathrm{X}$ )

If yes, HQ Program Element

Brief Summary of Relevant Information (major permit conditions, status of compliance or unusual problems):

Approval of this application allows the Environmental Analytical Laboratory to perform timely radiological screening and analysis. Approval was received from the EPA on May 10, 1995. Analysis activities began in May 1995, and are continuing.

Prepared by: Bechtel Hanford, Inc.

Date: July 31, 1996

Regulatory Support 
The following information was prepared in response to requirements of DOE Order $5400.2 \mathrm{~A}$.

DOE Operations Office: Richland

DOE Facility: Hanford Site

Existing Permit (X) Renewal ( ) New Permit ( )

Permit Type: Notice of Construction for:

General Regulations for Air Pollution Sources - WAC 173-400

Controls for New Sources of Toxic Air Pollutants - WAC 173-460

Permitting Agency: Washington State Department of Ecology

Permit Number: NWP-95(8)-100N/EAL

Permitted Unit: Environmental Analytical Laboratory

Issuance Date: November 15, 1995

Expiration Date: N/A

Need for Headquarters' Action

(for permit renewals or new permits)
Yes ( ) No ( $X$ )

If yes, HQ Program Element

Brief Summary of Relevant Information (major permit conditions, status of compliance or unusual problems):

Approval of this Notice of Construction allows the Environmental Analytical Laboratory to perform timely nonradiological screening and analyses. Approval was received from Ecology on November 15, 1995. Limited nonradiological analysis has been conducted to date.

Prepared by: Bechtel Hanford, Inc.

Date: July 31, 1996

Regulatory Support 
The following information was prepared in response to requirements of DOE Order $5400.2 \mathrm{~A}$.

DOE Operations Office: Richland

DOE Facility: Hanford Site

Existing Permit ( ) Renewal ( ) New Permit (X)

Permit Type: Radioactive Air Emissions Program Notice of Construction - WAC 246-247

Permitting Agency: State of Washington Department of Health

Permit Number: Routine Technical Assistance Meeting

Permitted Unit: Environmental Analytical Laboratory High-efficiency Particulate Air Filter Addition

Issuance Date: October 1995

Expiration Date: NA

Need for Headquarters' Action (for permit renewals or new permits)
Yes ( ) No (X)

If yes, HQ Program Element

Brief Summary of Relevant Information (major permit conditions, status of compliance or unusual problems):

Approval of this Notice of Construction allowed the installation of a high-efficiency particulate air filter unit on Trailer MO-426. To increase work space and to improve housekeeping, two existing laboratory hoods were to be connected by a common duct that connected into a new high-efficiency particulate air filter unit. This project was cancelled.

Prepared by: Westinghouse Hanford Company

Date: July 31, 1996

Environmental Services 
The following information was prepared in response to requirements of DOE Order $5400.2 \mathrm{~A}$.

DOE Operations Office: Richland

DOE Facility: Hanford Site

Existing Permit (X) Renewal ( ) New Permit ( )

Permit Type: Radioactive Air Emissions Program Notice of Construction - WAC 246-247

Permitting Agency: State of Washington Department of Health

Permit Number: AIR-94-803

Permitted Unit: Environmental Molecular Sciences Laboratory

Issuance Date: August 2, 1994

Expiration Date: N/A

Need for Headquarters' Action

(for permit renewals or new permits)

Yes ( ) No (X)

If yes, HQ Program Element

Brief Summary of Relevant Information (major permit conditions, status of compliance or unusual problems):

Approval of this Notice of Construction allows the Environmental Molecular Sciences Laboratory to be constructed and to operate in a location near the 300 Area. The Environmental Molecular Sciences Laboratory is a new multi-user laboratory providing the necessary complement of capabilities designed for research and development activities to solve environmental restoration and waste management problems on the Hanford Site. On August 2, 1994, an approval letter was received from the Department of Health. The Environmental Molecular Sciences Laboratory is under construction.

Prepared by: Pacific Northwest National Laboratory

Date: July 31, 1996 Environmental Compliance 
The following information was prepared in response to requirements of DOE Order $5400.2 \mathrm{~A}$.

DOE Operations Office: Richland

DOE Facility: Hanford Site

Existing Permit (X) Renewal ( ) New Permit ( )

Permit Type: National Emission Standard for Hazardous Air Pollutants (NESHAPs) 40 CFR 61, Subpart H

Permitting Agency: U.S. Environmental Protection Agency, Region 10

Permit Number: N/A

Permitted Unit: Environmental Molecular Sciences Laboratory

Issuance Date: July 6, 1994

Expiration Date: N/A

Need for Headquarters' Action

(for permit renewals or new permits)
Yes ( ) No (X)

If yes, HQ Program Element

Brief Summary of Relevant Information (major permit conditions, status of compliance or unusual problems):

Approval of this application allows the Environmental Molecular Sciences Laboratory to be constructed and to operate in a location near the 300 Area. The Environmental Molecular Sciences Laboratory is a new multi-user laboratory providing the necessary complement of capabilities designed for research and development activities to solve environmental restoration and waste management problems on the Hanford Site. On July 6, 1994, an approval letter was received from the EPA. The Environmental Molecular Sciences Laboratory is under construction.

Prepared by: Pacific Northwest National Laboratory

Date: July 31, 1996

Environmental Compliance 
The following information was prepared in response to requirements of DOE Order $5400.2 \mathrm{~A}$.

DOE Operations Office: Richland

DOE Facility: Hanford Site

Existing Permit (X) $\quad$ Renewal ( ) New Permit ( )

Permit Type: Notice of Construction for:

General Regulations for Air Pollution Sources - WAC 173-400

Controls for New Sources of Toxic Air Pollutants - WAC 173-460

Permitting Agency: Washington State Department of Ecology

Permit Number: NOC-94-08

Permitted Unit: Environmental Molecular Sciences Laboratory

Issuance Date: September 12, 1994

Expiration Date: N/A

Need for Headquarters' Action

(for permit renewals or new permits)
Yes ( ) No (X)

If yes, HQ Program Element

Brief Summary of Relevant Information (major permit conditions, status of compliance or unusual problems):

Approval of this Notice of Construction allows the Environmental Molecular Sciences Laboratory to be constructed and to operated in a location near the 300 Area. The Environmental Molecular Sciences Laboratory is a new multi-user laboratory providing the necessary complement of capabilities designed for research and development activities to solve environmental restoration and waste management problems on the Hanford Site. The Notice of Construction was approved by Ecology on September 12, 1994, with emission limits for ammonia and volatile organic compounds, as well as source testing requirements. The Environmental Molecular Sciences Laboratory is under construction.

Prepared by: Pacific Northwest National Laboratory

Date: July 31,1996

Environmental Compliance 
The following information was prepared in response to requirements of DOE Order 5400.2A.

DOE Operations Office: Richland

DOE Facility: Hanford Site

Existing Permit ( ) Renewal ( ) New Permit (X)

Permit Type: Radioactive Air Emissions Program Notice of Construction - WAC 246-247

Permitting Agency: State of Washington Department of Health

Permit Number: N/A

Permitted Unit: High-Level Vault Tanks Remediation, 324 Building

Issuance Date: July 10, 1996

Expiration Date: N/A

Need for Headquarters' Action

(for permit renewals or new permits)
Yes ( ) No (X)

If yes, HQ Program Element

Brief Summary of Relevant Information (major permit conditions, status of compliance or unusual problems):

Approval of this Notice of Construction allows remediation of the High-Level Vault Tanks. The remediation consists of processing the liquid waste in the High-Level Vault Tanks in the 324 Building. The liquid waste will run through several processes to eliminate waste components. On July 10, 1996, an approval letter was received from the Department of Health. The liquid waste in the High-Level Vault Tanks is being processed.

Prepared by: Pacific Northwest National Laboratory

Date: July 31, 1996 Environmental Compliance 
The following information was prepared in response to requirements of DOE Order 5400.2A.

DOE Operations Office: Richland

DOE Facility: Hanford Site

Existing Permit ( ) Renewal ( ) New Permit (X)

Permit Type: National Emission Standard for Hazardous Air Pollutants (NESHAPs) 40 CFR 61, Subpart H

Permitting Agency: U.S. Environmental Protection Agency, Region 10

Permit Number: N/A

Permitted Unit: High-Level Vault Tanks Remediation, 324 Building

Issuance Date: April 17, 1996

Expiration Date: N/A

Need for Headquarters' Action

(for permit renewals or new permits)
Yes ( ) No (X)

If yes, HQ Program Element

Brief Summary of Relevant Information (major permit conditions, status of compliance or unusual problems):

Approval of this application allows remediation of the High-Level Vault Tanks. The remediation consists of processing the liquid waste in the High-Level Vault Tanks in the 324 Building. The liquid waste will run through several processes to eliminate waste components. On April 17, 1996, an approval letter was received from the EPA. The liquid waste in the High-Level Vault Tanks is being processed. 
The following information was prepared in response to requirements of DOE Order $5400.2 \mathrm{~A}$.

DOE Operations Office: Richland

DOE Facility: Hanford Site

Existing Permit ( ) Renewal ( ) New Permit (X)

Permit Type: Radioactive Air Emissions Program Notice of Construction - WAC 246-247

Permitting Agency: State of Washington Department of Health

Permit Number: Routine Technical Assistance Meeting

Permitted Unit: Inactive Miscellaneous Underground Storage Tanks Sampling/Characterization

Issuance Date: January 1996

Expiration Date: NA

Need for Headquarters' Action

(for permit renewals or new permits)

\author{
Yes ( ) No (X) \\ If yes, HQ Program Element
}

Brief Summary of Relevant Information (major permit conditions, status of compliance or unusual problems):

Approval of this Notice of Construction allows the sampling/characterization of the balance of the Inactive Miscellaneous Underground Storage Tanks (approximately 36). The removal involves installing the initial controls, sniffing for lower flammability limit levels, and entering the tank for packaging/removal of loose equipment for disposal. During the period covered by this Status Report, these activities proceeded with no compliance issues.

Prepared by: Westinghouse Hanford Company

Date: July 31, 1996

Environmental Services 
The following information was prepared in response to requirements of DOE Order 5400.2A.

DOE Operations Office: Richland

DOE Facility: Hanford Site

Existing Permit ( ) Renewal ( ) New Permit (X)

Permit Type: Radioactive Air Emissions Program Notice of Construction - WAC 246-247

Permitting Agency: State of Washington Department of Health

Permit Number: AIR-96-902

Permitted Unit: Initial Tank Retrieval System for 241-SY-102 Tank, Project W-211

Issuance Date: September 11, 1996

Expiration Date: N/A

Need for Headquarters' Action

(for permit renewals or new permits)
Yes ( ) No (X)

If yes, HQ Program Element

Brief Summary of Relevant Information (major permit conditions, status of compliance or unusual problems):

Approval of this Notice of Construction allows for the installation and operation of two mixer pumps in the 241-SY-102 tank in accordance with descriptions contained in the application. Other conditions require head space sampling during startup and peak operations and exclusive use of the new primary exhauster during peak operation. The primary objective of the Initial Tank Retrieval System is to support tank waste treatment and disposal. The retrieval capabilities also are used to consolidate compatible tank waste to create additional double-shell tank storage space. During the period covered by this Status Report, this project proceeded with no compliance issues.

Prepared by: Westinghouse Hanford Company

Date: July 31,1996 Environmental Services 
The following information was prepared in response to requirements of DOE Order 5400.2A.

DOE Operations Office: Richland

DOE Facility: Hanford Site

Existing Permit ( ) Renewal ( ) New Permit (X)

Permit Type: National Emission Standard for Hazardous Air Pollutants (NESHAPs) 40 CFR 61, Subpart $H$

Permitting Agency: U.S. Environmental Protection Agency, Region 10

Permit Number: N/A

Permitted Unit: Initial Tank Retrieval System for 241-SY-102 Tank, Project W-211

Issuance Date: March 15, 1996

Expiration Date: N/A

Need for Headquarters' Action

(for permit renewals or new permits)
Yes ( ) No (X)

If yes, HQ Program Element

Brief Summary of Relevant Information (major permit conditions, status of compliance or unusual problems):

Approval of this application allows for the installation and operation of two mixer pumps in the 241-SY-102 tank in accordance with descriptions contained in the application. Other conditions require head space sampling during startup and peak operations and exclusive use of the new primary exhauster during peak operation. The primary objective of the Initial Tank Retrieval System is to support tank waste treatment and disposal. The retrieval capabilities also are used to consolidate compatible tank waste to create additional double-shell tank storage space. During the period covered by this Status Report, this project proceeded with no compliance issues.

Prepared by: Westinghouse Hanford Company

Date: July 31,1996

Environmental Service 
The following information was prepared in response to requirements of DOE Order $5400.2 \mathrm{~A}$.

DOE Operations Office: Richland

DOE Facility: Hanford Site

Existing Permit ( ) $\quad$ Renewal ( ) New Permit (X)

Permit Type: Radioactive Air Emissions Program Notice of Construction - WAC 246-247

Permitting Agency: State of Washington Department of Health

Permit Number: Routine Technical Assistance Meeting

Permitted Unit: Low-Level Burial Grounds Mixed Waste Disposal Trench 34 Leachate Collection Tank

Issuance Date: August 1995

Expiration Date: NA

Need for Headquarters' Action

(for permit renewals or new permits)
Yes ( ) No (X)

If yes, HQ Program Element

Brief Summary of Relevant Information (major permit conditions, status of compliance or unusual problems):

Approval of this Notice of Construction allows the development and use of the Low-Level Burial Grounds Mixed Waste Disposal Trench 34 Leachate Collection Tank, and transfers from the collection tank to tanker trucks. This is the second leachate collection tank to operate and will operate like the Trench 31 Leachate Collection System. The Department of Health determined that the operation of the leachate collection system had no potential-to-emit. During the period covered by this Status Report, the Low-Level Burial Grounds Mixed Waste Disposal Trench 34 Leachate Collection Tank operated with no compliance issues.

Prepared by: Westinghouse Hanford Company

Date: July 31, 1996 Environmental Services 
The following information was prepared in response to requirements of DOE Order 5400.2A.

DOE Operations Office: Richland

DOE Facility: Hanford Site

Existing Permit ( ) Renewal ( ) New Permit (X)

Permit Type: Radioactive Air Emissions Program Notice of Construction - WAC 246-247

Permitting Agency: State of Washington Department of Health

Permit Number: Routine Technical Assistance Meeting

Permitted Unit: Operation of Portable Exhauster in Conjunction with the Light Duty Utility Arm

Issuance Date: March 1996

Expiration Date: NA

Need for Headquarters' Action

(for permit renewals or new permits)
Yes ( ) No (X)

If yes, HQ Program Element

Brief Summary of Relevant Information (major permit conditions, status of compliance or unusual problems):

Approval of this Notice of Construction allows the use of the Light Duty Utility Arm in conjunction with an exhauster on passively ventilated single-shell tanks as a contingency measure. The Light Duty Utility Arm is a tank characterization tool developed to characterize the single-shell and double-shell tanks and their contents, especially in areas not directly below the access risers. The Light Duty Utility Arm normally is operated without an exhauster; however, use of an exhauster adds flexibility for the possibility of fog in a tank or to satisfy a safety requirement to actively ventilate a tank. During the period covered by this Status Report, the operation of a portable exhauster in conjunction with the Light Duty Utility Arm proceeded with no compliance issues. 
The following information was prepared in response to requirements of DOE Order 5400.2A.

DOE Operations Office: Richland

DOE Facility: Hanford Site

Existing Permit ( ) Renewal ( ) New Permit (X)

Permit Type: National Emission Standard for Hazardous Air Pollutants (NESHAPs) 40 CFR 61, Subpart H

Permitting Agency: U.S. Environmental Protection Agency, Region 10

Permit Number: N/A

Permitted Unit: Operation of a Portable Exhauster in Conjunction with the Light Duty Utility Arm

Issuance Date: July 2, 1996

Expiration Date: N/A

Need for Headquarters' Action

(for permit renewals or new permits)
Yes ( ) No (X)

If yes, HQ Program Element

Brief Summary of Relevant Information (major permit conditions, status of compliance or unusual problems):

Approval of this application allows for the operation of a portable exhauster on passively ventilated tanks while deploying a Light Duty Utility Arm in accordance with descriptions contained in the application. The Light Duty Utility Arm is a tank characterization tool developed to characterize the single-shell and double-shell tanks and their contents, especially in areas not directly below the access risers. The Light Duty Utility Arm normally is operated without an exhauster; however, use of an exhauster adds flexibility for the possibility of fog in a tank or to satisfy a safety requirement to actively ventilate a tank. During the period covered by this Status Report, the operation of a portable exhauster in conjunction with the Light Duty Utility Arm proceeded with no compliance issues.

Prepared by: Westinghouse Hanford Company

Date: July 31, 1996

Environmental Services 
The following information was prepared in response to requirements of DOE Order 5400.2A.

DOE Operations Office: Richland

DOE Facility: Hanford Site

Existing Permit ( ) Renewal ( ) New Permit (X)

Permit Type: Radioactive Air Emissions Program Notice of Construction - WAC 246-247

Permitting Agency: State of Washington Department of Health

Permit Number: AIR-96-403

Permitted Unit: Plasma Arc Furnace, 324 Building

Issuance Date: April 18, 1996

Expiration Date: N/A

Need for Headquarters' Action

(for permit renewals or new permits)
Yes ( ) No (X)

If yes, $\mathrm{HQ}$ Program Element

Brief Summary of Relevant Information (major permit conditions, status of compliance or unusual problems):

Approval of this Notice of Construction allows construction of a large walk-in fume hood containing a direct current plasma arc furnace and its associated offgas treatment and feed systems. On April 18, 1996, an approval letter was received from the Department of Health. Preparations are underway to operate the plasma arc furnace.

Prepared by: Pacific Northwest National Laboratory

Date: July 31,1996 Environmental Compliance 
The following information was prepared in response to requirements of DOE Order $5400.2 \mathrm{~A}$.

DOE Operations Office: Richland

DOE Facility: Hanford Site

Existing Permit ( ) Renewal ( ) New Permit (X)

Permit Type: National Emission Standard for Hazardous Air Pollutants (NESHAPs) 40 CFR 61, Subpart H

Permitting Agency: U.S. Environmental Protection Agency, Region 10

Permit Number: N/A

Permitted Unit: Plasma Arc Furnace, 324 Building

Issuance Date: April 3, 1996

Expiration Date: N/A

Need for Headquarters' Action

(for permit renewals or new permits)
Yes ( ) No (X)

If yes, HQ Program Element

Brief Summary of Relevant Information (major permit conditions, status of compliance or unusual. problems):

Approval of this application allows construction of a large walk-in fume hood containing a direct current plasma arc furnace and its associated offgas treatment and feed systems. On April 3, 1996, an approval letter was received from the EPA. Preparations are underway to operate the plasma arc furnace.

Prepared by: Pacific Northwest National Laboratory

Date: July 31,1996

Environmental Compliance 
The following information was prepared in response to requirements of DOE Order 5400.2A.

DOE Operations Office: Richland

DOE Facility: Hanford Site

Existing Permit ( ) Renewal ( ) New Permit (X)

Permit Type: Notice of Construction for:

General Regulations for Air Pollution Sources - WAC 173-400

Controls for New Sources of Toxic Air Pollutants - WAC 173-460

Permitting Agency: Washington State Department of Ecology

Permit Number: NWP-96-2

Permitted Unit: Plasma Arc Furnace, 324 Building

Issuance Date: May 20, 1996

Expiration Date: N/A

Need for Headquarters' Action

(for permit renewals or new permits)

\section{Yes ( ) No (X)}

If yes, HQ Program Element

Brief Summary of Relevant Information (major permit conditions, status of compliance or unusual problems):

Approval of this Notice of Construction allows construction of a large walk-in fume hood containing a direct current plasma arc furnace and its associated offgas treatment and feed systems. On May 20, 1996, a permit was received from Ecology. Preparations are underway to operate the plasma arc furnace.

Prepared by: Pacific Northwest National Laboratory

Date: July 31,1996

$$
\text { Environmental Compliance }
$$


The following information was prepared in response to requirements of DOE Order 5400.2A.

DOE Operations Office: Richland

DOE Facility: Hanford Site

Existing Permit ( ) Renewal ( ) New Permit (X)

Permit Type: Radioactive Air Emissions Program Notice of Construction - WAC 246-247

Permitting Agency: State of Washington Department of Health

Permit Number: Routine Technical Assistance Meeting

Permitted Unit: Plutonium Finishing Plant Cementation of Plutonium Bearing Materials

Issuance Date: May 1996

Expiration Date: NA

Need for Headquarters' Action

Yes ( ) No (X)

(for permit renewals or new permits)

If yes, HQ Program Element

Brief Summary of Relevant Information (major permit conditions, status of compliance or unusual problems):

Approval of this Notice of Construction allows the cementation of plutonium bearing materials. The cementation process will be consolidated into one location and will be similar to those cementing operations that the Plutonium Finishing Plant has done before in several gloveboxes. The rate of handling plutonium-bearing material was roughly equivalent to other routine glovebox operations in the Plutonium Finishing Plant. A description of the cementation activity also is discussed in the approved Plutonium Finishing Plant stabilization environmental impact statement. During the period covered by this Status Report, this activity proceeded with no compliance issues.

Prepared by: Westinghouse Hanford Company

Date: July 31, 1996 Environmental Services 
The following information was prepared in response to requirements of DOE Order 5400.2A.

DOE Operations Office: Richland

DOE Facility: Hanford Site

Existing Permit ( ) Renewal ( ) New Permit (X)

Permit Type: Radioactive Air Emissions Program Notice of Construction - WAC 246-247

Permitting Agency: State of Washington Department of Health

Permit Number: Routine Technical Assistance Meeting

Permitted Unit: Plutonium Finishing Plant Duct Work and Process Piping Remediation

Issuance Date: July 1996

Expiration Date: NA

Need for Headquarters' Action

(for permit renewals or new permits)

\author{
Yes ( ) No (X) \\ If yes, HQ Program Element
}

Brief Summary of Relevant Information (major permit conditions, status of compliance or unusual problems):

Approval of this Notice of Construction allows an additional 11-meter (35-foot) segment of small diameter vacuum process piping to be remediated under the same conditions of a previously approved Notice of Construction. The additional 11 meters ( 35 feet) of piping has a source term of about 2 kilograms (4.4 pounds) of plutonium. This additional work will not have a dose potential exceeding 0.1 mili-rem per year. During the period covered by this Status Report, the remediation work at Plutonium Finishing Plant proceeded with no compliances issues.

Prepared by: Westinghouse Hanford Company

Date: July 31,1996

Environmental Services 
The following information was prepared in response to requirements of DOE Order 5400.2A.

DOE Operations Office: Richland

DOE Facility: Hanford Site

Existing Permit (X) Renewal ( ) New Permit ( )

Permit Type: Radioactive Air Emissions Program Notice of Construction - WAC 246-247

Permitting Agency: State of Washington Department of Health

Permit Number: N/A

Permitted Unit: Plutonium Finishing Plant Low-Level Waste Treatment Facility

Issuance Date: July 30, 1992

Expiration Date: N/A

Need for Headquarters' Action

(for permit renewals or new permits)
Yes ( ) No (X)

If yes, HQ Program Element

Brief Summary of Relevant Information (major permit conditions, status of compliance or unusual problems):

Approval of this Notice of Construction allows construction of the Plutonium Finishing Plant Low-Level Waste Treatment Facility using approved radionuclide air emissions control equipment. This facility treats low-level waste water from the Plutonium Finishing Plant. No revisions of the Radioactive Air Emissions Program Notice of Construction have been submitted. During the period covered by this Status Report, the Low-Level Waste Treatment Facility activities proceeded with no compliance issues.

Prepared by: Westinghouse Hanford Company

Date: July 31, 1996

Environmental Services 
The following information was prepared in response to requirements of DOE Order 5400.2A.

DOE Operations Office: Richland

DOE Facility: Hanford Site
Existing Permit (X)
Renewal ( )
New Permit ( )

Permit Type: Radioactive Air Emissions Program Notice of Construction - WAC 246-247

Permitting Agency: State of Washington Department of Health

Permit Number: AIR-95-401

Permitted Unit: Plutonium Recycle Test Reactor Vault Cleanout

Issuance Date: April 3, 1995

Expiration Date: N/A

Need for Headquarters' Action

(for permit renewals or new permits)

\section{Yes ( ) No (X)}

If yes, HQ Program Element

Brief Summary of Relevant Information (major permit conditions, status of compliance or unusual problems):

Approval of this Notice of Construction was granted subject to the Plutonium Recycle Test Reactor Vault Cleanout being constructed and operated in accordance with descriptions contained in the application. In support of decontamination and decommissioning efforts at the Plutonium Recycle Test Reactor, the ion exchange columns in the Plutonium Recycle Test Reactor Vault were removed and buried on the Hanford Site. This activity was completed with no compliance issues.

Prepared by: Westinghouse Hanford Company

Date: July 31,1996 Environmental Services 
The following information was prepared in response to requirements of DOE Order $5400.2 \mathrm{~A}$.

DOE Operations Office: Richland

DOE Facility: Hanford Site

Existing Permit (X) Renewal ( ) New Permit ( )

Permit Type: National Emission Standard for Hazardous Air Pollutants (NESHAPs) 40 CFR 61, Subpart H

Permitting Agency: U.S. Environmental Protection Agency, Region 10

Permit Number: N/A

Permitted Unit: Plutonium Recycle Test Reactor Vault Cleanout

Issuance Date: April 18, 1995

Expiration Date: N/A

Need for Headquarters' Action

(for permit renewals or new permits)
Yes ( ) No (X)

If yes, HQ Program Element

Brief Summary of Relevant Information (major permit conditions, status of compliance or unusual problems):

Approval of this application was granted subject to the Plutonium Recycle Test Reactor Vault Cleanout being constructed and operated in accordance with descriptions contained in the application. In support of decontamination and decommissioning efforts at the Plutonium Recycle Test Reactor, the ion exchange columns in the Plutonium Recycle Test Reactor Vault were removed and buried on the Hanford Site. This activity was completed with no compliance issues.

Prepared by: Westinghouse Hanford Company

Date: July 31, 1996

Environmental Services 
The following information was prepared in response to requirements of DOE Order $5400.2 \mathrm{~A}$.

DOE Operations Office: Richland

DOE Facility: Hanford Site

Existing Permit ( ) Renewal (X) New Permit ( )

Permit Type: Categorical Approval for Construction and Operation - WAC 246-247

Permitting Agency: State of Washington Department of Health

Permit Number: AIR-95-109

Permitted Unit: Portable Exhausters

Issuance Date: January 27, 1995

Expiration Date: N/A

Need for Headquarters' Action

(for permit renewals or new permits)
Yes ( ) No (X)

If yes, HQ Program Element

Brief Summary of Relevant Information (major permit conditions, status of compliance or unusual problems):

The Categorical Approval for Construction and Operation is a Hanford Sitewide Categorical Approval to construct and operate portable and temporary radionuclide airborne emissions equipment. The Notice of Construction, submitted in March 1992, requested permission to construct and operate portable and temporary radionuclide airborne emissions systems without prior notification to the Department of Health if expected emissions from each of the systems were below 0.1 milliroentgen equivalent man per year. Because portable and temporary radionuclide airborne emissions systems are operated mainly for temporary and emergency conditions, this Categorical Approval allows expedited response to field situations requiring such systems.

Prepared by: Westinghouse Hanford Company Environmental Services

Date: July 31,1996 
The following information was prepared in response to requirements of DOE Order 5400.2A.

DOE Operations Office: Richland

DOE Facility: Hanford Site

Existing Permit (X) Renewal ( ) New Permit ( )

Permit Type: Radioactive Air Emissions Program Notice of Construction - WAC 246-247

Permitting Agency: State of Washington Department of Heaith

Permit Number: AIR 95-109

Permitted Unit: Portable Exhauster for Flammable Watchlist Single-Shell Tank System

Issuance Date: July 11, 1995

Expiration Date: N/A

Need for Headquarters' Action

(for permit renewals or new permits)
Yes ( ) No (X)

If yes, HQ Program Element

Brief Summary of Relevant Information (major permit conditions, status of compliance or unusual problems):

Approval of this Notice of Construction allows the use of a portable exhauster on single-shell tanks included on the flammable watchlist using approved radionuclide air emissions control equipment in accordance with descriptions contained in the application. To mitigate personnel safety concerns during the installation of the thermocouple trees and other equipment, an active means of removing vapors from the tanks is provided when waste intrusive work is being performed. During the period covered by this Status Report, the portable exhausters operated with no compliance issues.

Prepared by: Westinghouse Hanford Company

Date: July 31, 1996 Environmental Services 
The following information was prepared in response to requirements of DOE Order $5400.2 \mathrm{~A}$.

DOE Operations Office: Richland

DOE Facility: Hanford Site

Existing Permit ( ) Renewal ( ) New Permit (X)

Permit Type: National Emission Standard for Hazardous Air Pollutants (NESHAPs) 40 CFR 61, Subpart H

Permitting Agency: U.S. Environmental Protection Agency, Region 10

Permit Number: I96-PCA-145

Permitted Unit: Portable Exhauster for Flammable Watchlist Single-Shell Tank System

Issuance Date: December 6, 1995

Expiration Date: N/A

Need for Headquarters' Action

(for permit renewals or new permits).
Yes ( ) No (X)

If yes, HQ Program Element

Brief Summary of Relevant Information (major permit conditions, status of compliance or unusual problems):

Approval of this application allows the use of a portable exhauster on single-shell tanks included on the flammable watchlist in accordance with descriptions contained in the application. To mitigate personnel safety concerns during the installation of the thermocouple trees and other equipment, an active means of removing vapors from the tanks is provided when waste intrusive work is being performed. During the period covered by this Status Report, the portable exhausters operated with no compliance issues.

Prepared by: Westinghouse Hanford Company

Date: July 31, 1996

Environmental Services 
The following information was prepared in response to requirements of DOE Order 5400.2A.

DOE Operations Office: Richland

DOE Facility: Hanford Site

Existing Permit ( ) Renewal ( ) New Permit (X)

Permit Type: Radioactive Air Emissions Program Notice of Construction - WAC 246-247

Permitting Agency: State of Washington Department of Health

Permit Number: Routine Technical Assistance Meeting

Permitted Unit: Portable/Temporary Radioactive Air Emission Units Annual Reporting Change

Issuance Date: March 1996

Expiration Date: NA

Need for Headquarters' Action

(for permit renewals or new permits)
Yes ( ) No (X)

If yes, HQ Program Element

Brief Summary of Relevant Information (major permit conditions, status of compliance or unusual problems):

Approval of this Notice of Construction allows the changing of the Portable/Temporary Radioactive Air Emission Units Bi-annual Report to an Annual Report. During the period covered by this Status Report, this activity proceeded with no compliance issues.

Prepared by: Westinghouse Hanford Company

Date: July 31, 1996 Environmental Services 
DOE/RL-96-63, Rev. 0

The following information was prepared in response to requirements of DOE Order 5400.2A.

DOE Operations Office: Richland

DOE Facility: Hanford Site

Existing Permit (X) Renewal ( ) New Permit ( )

Permit Type: Radioactive Air Emissions Program Notice of Construction - WAC 246-247

Permitting Agency: State of Washington Department of Health

Permit Number: AIR-94-313

Permitted Unit: PUREX Plant Deactivation

Issuance Date: March 30, 1994

Expiration Date: N/A

Need for Headquarters' Action

(for permit renewals or new permits)
Yes ( ) No ( $\mathrm{X}$ )

If yes, HQ Program Element

Brief Summary of Relevant Information (major permit conditions, status of compliance or unusual problems):

Approval of this Notice of Construction allows deactivation activities to prepare the PUREX Plant for final closure and decommissioning. Approval was granted contingent on the deactivation being operated in accordance with descriptions contained in the application. The $\mathrm{UO}_{3}$ and PUREX facilities addressed with limits in the Notice of Construction have been permanently shutdown. During the period covered by this Status Report, the PUREX Plant deactivation proceeded with no compliance issues.

Prepared by: Westinghouse Hanford Company

Date: July 31,1996

Environmental Services 
The following information was prepared in response to requirements of DOE Order 5400.2A.

DOE Operations Office: Richland

DOE Facility: Hanford Site

Existing Permit (X) Renewal ( ) New Permit ( )

Permit Type: Prevention of Significant Deterioration - -40 CFR 52

Permitting Agency: U.S. Environmental Protection Agency, Region 10

Permit Number: PSD-X80-14

Permitted Unit: PUREX Deactivation

Issuance Date: September 30, 1980

Expiration Date: N/A

Need for Headquarters' Action

(for permit renewals or new permits)
Yes ( ) No (X)

If yes, HQ Program Element

Brief Summary of Relevant Information (major permit conditions, status of compliance or unusual problems):

This permit governs the release of nitrous oxide from nuclear fuel reprocessing units on the Hanford Site. The major permit conditions include discharge points and daily and yearly effluent limitations, and continue in force. No revisions to the permit have been submitted. The $\mathrm{UO}_{3}$ and PUREX Plant facilities addressed with limits in the permit have been permanently shutdown. The existing permit issued in September 1980 was considered adequate for deactivation of the PUREX Plant facilities (assuming the sugar denitration process is not employed) if the $\mathrm{No}_{\mathrm{x}}$ monitoring system and emission limitation requirements were met. The sugar denitration was not used during deactivation, and the monitoring system has been shutdown. During the period covered by this Status Report, the PUREX Plant deactivation proceeded with no compliance issues.

Prepared by: Westinghouse Hanford Company

Date: July 31, 1996

Environmental Services 
The following information was prepared in response to requirements of DOE Order 5400.2A.

DOE Operations Office: Richland

DOE Facility: Hanford Site

Existing Permit ( ) Renewal ( ) New Permit (X)

Permit Type: Radioactive Air Emissions Program Notice of Construction - WAC 246-247

Permitting Agency: State of Washington Department of Health

Permit Number: AIR-95-804

Permitted Unit: PUREX Plant Fuel Transfer to the 105-KW Basin

Issuance Date: August 14, 1995

Expiration Date: N/A

Need for Headquarters' Action

(for permit renewals or new permits)
Yes ( ) No (X)

If yes, HQ Program Element

Brief Summary of Relevant Information (major permit conditions, status of compliance or unusual problems):

Approval of this Notice of Construction allowed the activities planned at the $105-\mathrm{KW}$ Basin to proceed, once the PUREX Plant fuel had been delivered to the 105-KW Basin, in accordance with descriptions contained in the application. The application also provides as background, an explanation of the fuel packing process at the PUREX Plant. This activity was completed with no compliance issues.

Prepared by: Westinghouse Hanford Company

Date: July 31,1996 Environmental Services 
The following information was prepared in response to requirements of DOE Order 5400.2A.

DOE Operations Office: Richland

DOE Facility: Hanford Site

Existing Permit ( $X$ ) Renewal ( ) New Permit ( )

Permit Type: National Emission Standard for Hazardous Air Pollutants (NESHAPs) 40 CFR 61, Subpart H

Permitting Agency: U.S. Environmental Protection Agency, Region 10

Permit Number: N/A

Permitted Unit: PUREX Plant Fuel Transfer to the 105-KW Basin

Issuance Date: July 11, 1995

Expiration Date: N/A

Need for Headquarters' Action

(for permit renewals or new permits)
Yes ( ) No (X)

If yes, HQ Program Element

Brief Summary of Relevant Information (major permit conditions, status of compliance or unusual problems):

Approval of this application allowed the activities planned at the $105-\mathrm{KW}$ Basin to proceed, once the PUREX Plant fuel had been delivered to the 105-KW Basin, in accordance with descriptions contained in the application. The application also provides as background, an explanation of the fuel packing process at the PUREX Plant. This activity was completed with no compliance issues.

Prepared by: Westinghouse Hanford Company

Date: July 31, 1996

Environmental Services 
The following information was prepared in response to requirements of DOE Order 5400.2A.

DOE Operations Office: Richland

DOE Facility: Hanford Site

Existing Permit ( ) Renewal ( ) New Permit (X)

Permit Type: Radioactive Air Emissions Program Notice of Construction - WAC 246-247

Permitting Agency: State of Washington Department of Health

Permit Number: Routine Technical Assistance Meeting

Permitted Unit: PUREX Stack Monitoring and Sampling Requirements Modification

Issuance Date: December 1995

Expiration Date: NA

Need for Headquarters' Action

(for permit renewals or new permits)
Yes ( ) No (X)

If yes, HQ Program Element

Brief Summary of Relevant Information (major permit conditions, status of compliance or unusual problems):

Approval of this Notice of Construction allows the modification of stack monitoring activities at the PUREX Plant. As stacks are shutdown, monitoring requirements are being reviewed. The canyon exhaust on-line stack monitoring will be left in place while the 324 Building waste remains in the PUREX canyon. Sample collection frequency was changed from biweekly to monthly. During the period covered by this Status Report, the PUREX Plant activities proceeded with no compliance issues.

Prepared by: Westinghouse Hanford Company

Date: July 31, 1996 Environmental Services 
The following information was prepared in response to requirements of DOE Order 5400.2A.

DOE Operations Office: Richland

DOE Facility: Hanford Site

Existing Permit (X) Renewal ( ) New Permit ( )

Permit Type: Prevention of Significant Deterioration - 40 CFR 52

Permitting Agency: U.S. Environmental Protection Agency, Region 10

Permit Number: PSD-X80-14

Permitted Unit: PUREX/UO ${ }_{3}$ Fuel Processing

Issuance Date: September 30, 1980

Expiration Date: N/A

Need for Headquarters' Action

(for permit renewals or new permits)
Yes ( ) No (X)

If yes, HQ Program Element

Brief Summary of Relevant Information (major permit conditions, status of compliance or unusual problems):

This permit governs the release of nitrous oxide from nuclear fuel reprocessing units on the Hanford Site. The major permit conditions include discharge points and daily and yearly effluent limitations, and continue in force. No revisions to the permit have been submitted. The $\mathrm{UO}_{3}$ and PUREX Plant facilities addressed with limits in the permit have been permanently shutdown. The existing permit issued in September 1980 was considered adequate for deactivation of the PUREX Plant (assuming the sugar denitration process is not employed) if the $\mathrm{No}_{x}$ monitoring system and emission limitation requirements were met. The sugar denitration was not used during deactivation, and the monitoring system has been shutdown. During the period covered by this Status Report, the PUREX Plant deactivation proceeded with no compliance issues.

Prepared by: Westinghouse Hanford Company

Date: July 31, 1996 Environmental Services 
The following information was prepared in response to requirements of DOE Order 5400.2A.

DOE Operations Office: Richland

DOE Facility: Hanford Site

Existing Permit ( ) Renewal ( ) New Permit (X)

Permit Type: Radioactive Air Emissions Program Notice of Construction — WAC 246-247

Permitting Agency: State of Washington Department of Health

Permit Number: Routine Technical Assistance Meeting

Permitted Unit: PUREX Use of Kelly Vacuum as a Portable, Temporary Radioactive Air Emission Unit

Issuance Date: June 1996

Expiration Date: NA

Need for Headquarters' Action

Yes ( ) No (X)

(for permit renewals or new permits)

If yes, HQ Program Element

Brief Summary of Relevant Information (major permit conditions, status of compliance or unusual problems):

Approval of this Notice of Construction allows the use of the Kelly vacuum as a portable, temporary radioactive air emission unit. Major conditions for using the Kelly vacuum require that the amount of surface area to be cleaned does not exceed the daily handling limits. This approval defined a category of use for the Kelly vacuum unit that could be accomplished without seeking separate Department of Health approval. During the period covered by this Status Report, this activity proceeded with no compliance issues.

Prepared by: Westinghouse Hanford Company

Date: July 31,1996

Environmental Services 
The following information was prepared in response to requirements of DOE Order 5400.2A.

DOE Operations Office: Richland

DOE Facility: Hanford Site

Existing Permit ( ) Renewal ( ) New Permit (X)

Permit Type: Radioactive Air Emissions Program Notice of Construction - WAC 246-247

Permitting Agency: State of Washington Department of Health

Permit Number: AIR-95-803

Permitted Unit: Radon Research Facility, 331 Building

Issuance Date: August 8, 1995

Expiration Date: N/A

Need for Headquarters' Action

(for permit renewals or new permits)

\section{Yes ( ) No (X)}

If yes, HQ Program Element

Brief Summary of Relevant Information (major permit conditions, status of compliance or unusual problems):

The Radon Research Facility was originally permitted to be installed in the 331 Building, Life Sciences Laboratory. Radon research involves the evaluation worker and public health and safety issues related to radon in the work place and the environment. Because of program changes, a request was made to the Department of Health to relocate the radon research facility to an undetermined location within the 300 Area. The Department of Health approved the relocation pending the potential-to-emit did not affect the NESHAP status of the building, and all controls, or equivalent, committed to in the original Notice of Construction were installed.

Prepared by: Pacific Northwest National Laboratory

Date: July 31, 1996

Environmental Compliance 
The following information was prepared in response to requirements of DOE Order 5400.2A.

DOE Operations Office: Richland

DOE Facility: Hanford Site

Existing Permit ( ) Renewal ( ) New Permit (X)

Permit Type: National Emission Standard for Hazardous Air Pollutants (NESHAPs) 40 CFR 61, Subpart H

Permitting Agency: U.S. Environmental Protection Agency, Region 10

Permit Number: N/A

Permitted Unit: Radon Research Facility, 331 Building

Issuance Date: August 8, 1995

Expiration Date: N/A

Need for Headquarters' Action

(for permit renewals or new permits)
Yes ( ) No (X)

If yes, HQ Program Element

Brief Summary of Relevant Information (major permit conditions, status of compliance or unusual problems):

The Radon Research Facility was originally permitted to be installed in the 331 Building, Life Sciences Laboratory. Radon research involves the evaluation or worker and public health and safety issues related to radon in the work place and the environment. The application was approved on August 8, 1995.

Prepared by: Pacific Northwest National Laboratory

Date: July 31, 1996 Environmental Compliance 
The following information was prepared in response to requirements of DOE Order 5400.2A.

DOE Operations Office: Richland

DOE Facility: Hanford Site

Existing Permit ( ) Renewal ( ) New Permit (X)

Permit Type: Radioactive Air Emissions Program Notice of Construction - WAC 246-247

Permitting Agency: State of Washington Department of Health

Permit Number: Routine Technical Assistance Meeting

Permitted Unit: Radon Generator Facility Relocation to Any Location Onsite

Issuance Date: May 1996

Expiration Date: NA

Need for Headquarters' Action

Yes ( ) No ( $X)$

(for permit renewals or new permits)

If yes, HQ Program Element

Brief Summary of Relevant Information (major permit conditions, status of compliance or unusual problems):

Approval of this Notice of Construction allows the movement of the Radon Generator Facility to any onsite location, in accordance with conditions contained in the Notice of Construction. The Department of Health determined that a formal Notice of Construction is not necessary unless the radioactive stack emissions are altered by the relocation. During the period covered by this Status Report, this activity proceeded with no compliance issues.

Prepared by: Pacific Northwest national Laboratory

Date: July 31, 1996 Environmental Compliance 
The following information was prepared in response to requirements of DOE Order 5400.2A.

DOE Operations Office: Richland

DOE Facility: Hanford Site

Existing Permit ( $X$ ) Renewal ( ) New Permit ( )

Permit Type: Radioactive Air Emissions Program Notice of Construction - WAC 246-247

Permitting Agency: State of Washington Department of Health

Permit Number: AIR-93-707

Permitted Unit: Rotary Mode Core-Sampling System Two

Issuance Date: July 8, 1993

Expiration Date: N/A

Need for Headquarters' Action

(for permit renewals or new permits)
Yes ( ) No (X)

If yes, HQ Program Element

Brief Summary of Relevant Information (major permit conditions, status of compliance or unusual problems):

Approval of this Notice of Construction allows an exhauster to be installed on the passively ventilated double-shell and single-shell tanks containing hard saltcake. This installation allows rotary mode core sampling of the tank contents using approved radionuclide air emissions control equipment in accordance with descriptions contained in the application. Rotary mode core sampling in these tanks requires nitrogen to be injected into the tank. The exhauster is required to prevent tank pressurization and to control emissions. The rotary mode core sampling is a Tri-Party Agreement Milestone (M-10-13). Several revisions of the Notice of Construction have been submitted to the Department of Health. On July 17, 1996, the Department of Health approved the revised potential-to-emit. This action redesignated the Rotary Mode Core-Sampling System Exhauster Two Stack to minor status. During the period covered by this Status Report, the Rotary Mode Core-Sampling System Two Stack operated with no compliance issues.

Prepared by: Westinghouse Hanford Company

Date: July 31, 1996

Environmental Services 
The following information was prepared in response to requirements of DOE Order 5400.2A.

DOE Operations Office: Richland

DOE Facility: Hanford Site

Existing Permit (X) Renewal ( ) New Permit ( )

Permit Type: National Emission Standard for Hazardous Air Pollutants (NESHAPs) 40 CFR 61, Subpart H

Permitting Agency: U.S. Environmental Protection Agency, Region 10

Permit Number: N/A

Permitted Unit: Rotary Mode Core Sampling System Two

Issuance Date: August 9, 1993

Expiration Date: N/A

Need for Headquarters' Action

(for permit renewals or new permits)

$$
\begin{aligned}
& \text { Yes ( ) No (X) } \\
& \text { If yes, HQ Program Element }
\end{aligned}
$$

Brief Summary of Relevant Information (major permit conditions, status of compliance or unusual problems):

Approval of this application allows an exhauster to be installed on the passively ventilated double-shell and single-shell tanks containing hard saltcake. This installation allows rotary mode core sampling of the tank contents using approved radionuclide air emissions control equipment in accordance with descriptions contained in the application. Rotary mode core sampling in these tanks requires nitrogen to be injected into the tank. The exhauster is required to prevent tank pressurization and to control emissions. The rotary mode core sampling is a Tri-Party Agreement Milestone (M-10-13). During the period covered by this Status Report, the Rotary Mode Core-Sampling System Two Stack operated with no compliance issues.

Prepared by: Westinghouse Hanford Company

Date: July 31, 1996

Environmental Services 
The following information was prepared in response to requirements of DOE Order 5400.2A.

DOE Operations Office: Richland

DOE Facility: Hanford Site

Existing Permit (X) Renewal ( ) New Permit ( )

Permit Type: Notice of Construction for:

General Regulations for Air Pollution Sources - WAC 173-400

Controls for New Sources of Toxic Air Pollutants - WAC 173-460

Permitting Agency: Washington State Department of Ecology

Permit Number: NOC-93-04

Permitted Unit: Rotary Mode Core Sampling Systems Two

Issuance Date: November 22, 1993

Expiration Date: N/A

Need for Headquarters' Action

(for permit renewals or new permits)
Yes ( ) No (X)

If yes, HQ Program Element

Brief Summary of Relevant Information (major permit conditions, status of compliance or unusual problems):

Approval of this Notice of Construction allows an exhauster to be installed on the passively ventilated double-shell and single-shell tanks containing hard saltcake. This installation allows rotary mode core sampling of the tank contents using approved radionuclide air emissions control equipment in accordance with descriptions contained in the application. Rotary mode core sampling in these tanks requires nitrogen to be injected into the tank. The exhauster is required to prevent tank pressurization and to control emissions. The rotary mode core sampling is a Tri-Party Agreement Milestone (M-10-13). Ecology reissued this permit with modifications on June 30, 1995. Modification of this permit currently is being negotiated with DOE-RL and Ecology, with a new permit and conditions scheduled for September 30, 1996.

Prepared by: Westinghouse Hanford Company

Date: July 31, 1996

Environmental Services 
The following information was prepared in response to requirements of DOE Order 5400.2A.

DOE Operations Office: Richland

DOE Facility: Hanford Site

Existing Permit (X) Renewal ( ) New Permit ( )

Permit Type: Radioactive Air Emissions Program Notice of Construction - WAC 246-247

Permitting Agency: State of Washington Department of Health

Permit Number: AIR-95-603

Permitted Unit: Rotary Mode Core-Sampling Systems Two, Three, and Four

Issuance Date: June 30, 1995

Expiration Date: N/A

Need for Headquarters' Action

(for permit renewals or new permits)

Yes ( ) No (X)
If yes, HQ Program Element

Brief Summary of Relevant Information (major permit conditions, status of compliance or unusual problems):

Approval of this Notice of Construction allows an exhauster to be installed on the passively ventilated double-shell and single-shell tanks containing hard saltcake. This installation allows rotary mode core sampling of the tank contents using approved radionuclide air emissions control equipment in accordance with descriptions contained in the application. Rotary mode core sampling in these tanks requires nitrogen to be injected into the tank. The exhauster is required to prevent tank pressurization and to control emissions. The rotary mode core sampling is a Tri-Party Agreement Milestone (M-10-13). Several revisions of the Notice of Construction have been submitted to and approved by the Department of Health. On July 17, 1996, the Department of Health approved the revised potential-to-emit. This action redesignated the Rotary Mode Core-Sampling System Exhauster Two Stack to minor status. During the period covered by this Status Report, the Rotary Mode Core-Sampling Systems Two, Three, and Four Stacks operated with no compliance issues.

Prepared by: Westinghouse Hanford Company

Date: July 31, 1996 Environmental Services 
The following information was prepared in response to requirements of DOE Order 5400.2A.

DOE Operations Office: Richland

DOE Facility: Hanford Site

Existing Permit (X) Renewal ( ) New Permit ( )

Permit Type: National Emission Standard for Hazardous Air Pollutants (NESHAPs) 40 CFR 61, Subpart H

Permitting Agency: U.S. Environmental Protection Agency, Region 10

Permit Number: N/A

Permitted Unit: Rotary Mode Core Sampling Systems Two, Three, and Four

Issuance Date: June 11, 1995

Expiration Date: N/A

Need for Headquarters' Action

Yes ( ) No (X)

(for permit renewals or new permits)

If yes, HQ Program Element

Brief Summary of Relevant Information (major permit conditions, status of compliance or unusual problems):

Approval of this application allows an exhauster to be installed on the passively ventilated double-shell and single-shell tanks containing hard saltcake. This installation allows sampling of the tank contents using approved nonradionuclide air emissions control equipment in accordance with descriptions contained in the application. Rotary mode core sampling in these tanks requires nitrogen to be injected into the tank. The exhauster is required to prevent tank pressurization and to control emissions. The rotary mode core sampling is a Tri-Party Agreement Milestone (M-10-13). During the period covered by this Status Report, the Rotary Mode Core-Sampling Systems Two, Three, and Four Stacks operated with no compliance issues.

Prepared by: Westinghouse Hanford Company

Date: July 31, 1996

Environmental Services 
The following information was prepared in response to requirements of DOE Order 5400.2A.

DOE Operations Office: Richland

DOE Facility: Hanford Site

Existing Permit (X) Renewal ( ) New Permit ( )

Permit Type: Notice of Construction for:

General Regulations for Air Pollution Sources - WAC 173-400

Controls for New Sources of Toxic Air Pollutants - WAC 173-460

Permitting Agency: Washington State Department of Ecology

Permit Number: NWP-95RMCS(3)

Permitted Unit: Rotary Mode Core Sampling Systems Two, Three, and Four

Issuance Date: June 30, 1995

Expiration Date: N/A

Need for Headquarters' Action

(for permit renewals or new permits)
Yes ( ) No $(X)$

If yes, HQ Program Element

Brief Summary of Relevant Information (major permit conditions, status of compliance or unusual problems):

Approval of this Notice of Construction allows an exhauster to be installed on the passively ventilated double-shell and single-shell tanks containing hard saltcake. This installation allows sampling of the tank contents using approved nonradionuclide air emissions control equipment in accordance with descriptions contained in the application. Rotary mode core sampling in these tanks requires nitrogen to be injected into the tank. The exhauster is required to prevent tank pressurization and to control emissions. The rotary mode core sampling is a Tri-Party Agreement Milestone (M-10-13). During the period covered by this Status Report, the Rotary Mode Core-Sampling Systems Two, Three, and Four Stacks operated with no compliance issues.

Prepared by: Westinghouse Hanford Company

Date: July 31,1996

Environmental Services 
The following information was prepared in response to requirements of DOE Order $5400.2 \mathrm{~A}$.

DOE Operations Office: Richland

DOE Facility: Hanford Site

Existing Permit ( X ) Renewal ( ) New Permit ( )

Permit Type: Radioactive Air Emissions Program Notice of Construction - WAC 246-247

Permitting Agency: State of Washington Department of Health

Permit Number: AIR 95-204

Permitted Unit: Sodium Storage Facility, Project F-031

Issuance Date: February 24, 1995

Expiration Date: N/A

Need for Headquarters' Action

Yes ( ) No (X)

(for permit renewals or new permits)

If yes, HQ Program Element

Brief Summary of Relevant Information (major permit conditions, status of compliance or unusual problems):

Approval of this Notice of Construction allows construction of the Sodium Storage Facility (Project F-031) in accordance with descriptions contained in the application. The Sodium Storage Facility supports the sodium offload from the Fast Flux Test Facility during transition to decommissioning. The Sodium Storage Facility receives molten sodium coolant from the Fast Flux Test Facility, stores the sodium in a solid state for an extended period, and melts the sodium for transfer to a future Sodium Reaction Facility. Approval of the Notice of Construction was granted with the understanding that the technology standards identified during the definitive design process would be submitted to the Department of Health when available, along with the associated costs of construction. Subsequently, the technology standards were submitted August 8, 1995, and the costs of construction were submitted August 22, 1995. During the period covered by this Status Report, this project proceeded with no compliance issues.

Prepared by: Westinghouse Hanford Company

Date: July 31, 1996 Environmental Services 
The following information was prepared in response to requirements of DOE Order 5400.2A.

DOE Operations Office: Richland

DOE Facility: Hanford Site

Existing Permit (X) Renewal ( ) New Permit ( )

Permit Type: National Emission Standard for Hazardous Air Pollutants (NESHAPs) 40 CFR 61, Subpart H

Permitting Agency: U.S. Environmental Protection Agency, Region 10

Permit Number: N/A

Permitted Unit: Sodium Storage Facility, Project F-031

Issuance Date: February 8, 1995

Expiration Date: N/A

Need for Headquarters' Action

(for permit renewals or new permits)

\section{Yes ( ) No ( $\mathrm{X}$ )}

If yes, HQ Program Element

Brief Summary of Relevant Information (major permit conditions, status of compliance or unusual problems):

Approval of this application allows construction of the Sodium Storage Facility (Project F-031) in accordance with descriptions contained in the application. The Sodium Storage Facility supports the sadium offload from the Fast Flux Test Facility during transition to decommissioning. The Sodium Storage Facility receives molten sodium coolant from the Fast Flux Test Facility, stores the sodium in a solid state for an extended period, and melts the sodium for transfer to a future Sodium Reaction Facility. During the period covered by this Status Report, this project proceeded with no compliance issues.

Prepared by: Westinghouse Hanford Company

Date: July 31, 1996 Environmental Services 
The following information was prepared in response to requirements of DOE Order 5400.2A.

DOE Operations Office: Richland

DOE Facility: Hanford Site

Existing Permit (X) Renewal ( ) New Permit ( )

Permit Type: Radioactive Air Emissions Program Notice of Construction - WAC 246-247

Permitting Agency: State of Washington Department of Health

Permit Number: AIR-94-404

Permitted Unit: Stabilization of the 105-N Basin

Issuance Date: April 11, 1994

Expiration Date: N/A

Need for Headquarters' Action (for permit renewals or new permits)
Yes ( ) No (X)

If yes, HQ Program Element

Brief Summary of Relevant Information (major permit conditions, status of compliance or unusual problems):

Approval of this Notice of Construction allows stabilization activities to commence at the 105-N Basin in the 100-N Area using approved radionuclide air emissions control equipment. Stabilization activities include work in preparation for final decontamination and decommissioning of the basin. Approval was received from the Department of Health on April 11, 1994. The $105-\mathrm{N}$ Basin stabilization activities began on May 30,1995, and work is in progress.

Prepared by: Bechtel Hanford, Inc.

Date: July 31,1996

Regulatory Support 
The following information was prepared in response to requirements of DOE Order 5400.2A.

DOE Operations Office: Richland

DOE Facility: Hanford Site

Existing Permit (X) Renewal ( ) New Permit ( )

Permit Type: National Emission Standard for Hazardous Air Pollutants (NESHAPs) - 40 CFR 61, Subpart H

Permitting Agency: U.S. Environmental Protection Agency, Region 10

Permit Number: N/A

Permitted Unit: Stabilization of the 105-N Basin

Issuance Date: May 10, 1994

Expiration Date: N/A

Need for Headquarters' Action

(for permit renewals or new permits)
Yes ( ) No (X)

If yes, HQ Program Element

Brief Summary of Relevant Information (major permit conditions, status of compliance or unusual problems):

Approval of this application allows stabilization activities to commence at the $105-\mathrm{N}$ Basin in the 100-N Area using approved radionuclide air emissions control equipment. Stabilization activities include work in preparation for final decontamination and decommissioning of the basin. Approval was received from the EPA on May 10, 1994. The 105-N Basin stabilization activities began on May 30, 1995, and work is in progress.

Prepared by: Bechtel Hanford, Inc.

Date: July 31,1996

Regulatory Support 
The following information was prepared in response to requirements of DOE Order 5400.2A.

DOE Operations Office: Richland

DOE Facility: Hanford Site

Existing Permit (X) Renewal ( ) New Permit ( )

Permit Type: Notice of Construction for:

General Regulations for Air Pollution Sources - WAC 173-400

Controls for New Sources of Toxic Air Pollutants - WAC 173-460

Permitting Agency: Washington State Department of Ecology

Permit Number: NOC-94-064 and NOC-94-06A

Permitted Unit: Steam Plant Rehabilitation, Phase II, Project L-017

Issuance Date: October 18, 1994 and May 31, 1994

Expiration Date: N/A

Need for Headquarters' Action

(for permit renewals or new permits)
Yes ( ) No (X)

If yes, HQ Program Element

Brief Summary of Relevant Information (major permit conditions, status of compliance or unusual problems):

Approval of this Notice of Construction allows construction of the standalone oil-fired package boiler in the 200 West Area. The backup boiler provides up to 18,662 kilograms per hour ( 50,000 pounds per hour) of steam. The boiler is intended to be brought on-line only in an event where demands exceed production of the coal-fired boilers, or because the steam-tie line is out of service. Major permit conditions include limits on hours of operation and emission rates. During the period covered by this Status Report, the Steam Plant operated with no compliance issues.

Prepared by: Westinghouse Hanford Company

Date: July 31,1996 Environmental Services 
The following information was prepared in response to requirements of DOE Order 5400.2A.

DOE Operations Office: Richland

DOE Facility: Hanford Site

Existing Permit ( ) Renewal ( ) New Permit (X)

Permit Type: Radioactive Air Emissions Program Notice of Construction - WAC 246-247

Permitting Agency: State of Washington Department of Health

Permit Number: N/A

Permitted Unit: Storage of the Liquid Waste Tank Cars and the 324 Building Waste in the PUREX Storage Tunnel Number 2

Issuance Date: June 7, 1996

Expiration Date: N/A

Need for Headquarters' Action

(for permit renewals or new permits)

\section{Yes ( ) No (X)}

If yes, HQ Program Element

Brief Summary of Relevant Information (major permit conditions, status of compliance or unusual problems):

Approval of this Notice of Construction allows the transfer and storage of up to four Liquid Waste Tank Cars and waste from the 324 Building to the PUREX Storage Tunnel Number 2 in accordance with descriptions contained in the application. During the period covered by this Status Report, this activity proceeded with no compliance issues.

Prepared by: Westinghouse Hanford Company

Date: July 31, 1996

Environmental Services 
The following information was prepared in response to requirements of DOE Order 5400.2A.

DOE Operations Office: Richland

DOE Facility: Hanford Site

Existing Permit ( ) Renewal ( ) New Permit (X)

Permit Type: National Emission Standard for Hazardous Air Pollutants (NESHAPs) 40 CFR 61, Subpart H

Permitting Agency: U.S. Environmental Protection Agency, Region 10

Permit Number: N/A

Permitted Unit: Storage of the Liquid Waste Tank Cars and the 324 Building Waste in the PUREX Storage Tunnel Number 2

Issuance Date: May 28, 1996

Expiration Date: N/A

Need for Headquarters' Action

(for permit renewals or new permits)
Yes ( ) No (X)

If yes, HQ Program Element

Brief Summary of Relevant Information (major permit conditions, status of compliance or unusual problems):

Approval of this application allows the transfer and storage of up to four Liquid Waste Tank Cars and waste from the 324 Building in the PUREX Storage Tunnel Number 2 in accordance with descriptions contained in the application. During the period covered by this Status Report, this activity proceeded with no compliance issues.

Prepared by: Westinghouse Hanford Company

Date: July 31,1996 Environmental Services 
The following information was prepared in response to requirements of DOE Order 5400.2A.

DOE Operations Office: Richland

DOE Facility: Hanford Site

Existing Permit ( ) Renewal ( ) New Permit (X)

Permit Type: Radioactive Air Emissions Program Notice of Construction - WAC 246-247

Permitting Agency: State of Washington Department of Health

Permit Number: AIR 96-607

Permitted Unit: Tank 241-A-101 Portable Exhauster

Issuance Date: June 17, 1996

Expiration Date: N/A

Need for Headquarters' Action

Yes ( ) No (X)

(for permit renewals or new permits)

If yes, HQ Program Element

Brief Summary of Relevant Information (major permit conditions, status of compliance or unusual problems):

Approval of this Notice of Construction allows active ventilation, via the use of a portable exhauster, on the 241-A-101 tank during salt well pumping and other routine activities performed in accordance with descriptions contained in the application. During the period covered by this Status Report, the portable exhauster activity proceeded with no compliance issues.

Prepared by: Westinghouse Hanford Company

Date: July 31, 1996

Environmental Services 
The following information was prepared in response to requirements of DOE Order $5400.2 \mathrm{~A}$.

DOE Operations Office: Richland

DOE Facility: Hanford Site

Existing Permit ( ) Renewal ( ) New Permit (X)

Permit Type: National Emission Standard for Hazardous Air Pollutants (NESHAPs) 40 CFR 61, Subpart H

Permitting Agency: U.S. Environmental Protection Agency, Region 10

Permit Number: N/A

Permitted Unit: Tank 241-A-101 Portable Exhauster

Issuance Date: July 2, 1996

Expiration Date: N/A

Need for Headquarters' Action

(for permit renewals or new permits)

\section{Yes ( ) No (X)}

If yes, HQ Program Element

Brief Summary of Relevant Information (major permit conditions, status of compliance or unusual problems):

Approval of this application allows active ventilation, via the use of a portable exhauster, on the 241-A-101 tank during salt well pumping and other routine activities performed in accordance with descriptions contained in the application. During the period covered by this Status Report, the portable exhauster activity proceeded with no compliance issues.

Prepared by: Westinghouse Hanford Company

Date: July 31,1996 Environmental Services 
The following information was prepared in response to requirements of DOE Order 5400.2A.

DOE Operations Office: Richland

DOE Facility: Hanford Site

Existing Permit ( ) Renewal ( ) New Permit (X)

Permit Type: Notice of Construction for:

General Regulations for Air Pollution Sources - WAC 173-400

Controls for New Sources of Toxic Air Pollutants - WAC 173-460

Permitting Agency: Washington State Department of Ecology

Permit Number: 96-NM-086

Permitted Unit: Tank 241-A-101 Portable Exhauster

Issuance Date: June 24, 1996

Expiration Date: N/A

Need for Headquarters' Action

Yes ( ) No (X)

(for permit renewals or new permits)

If yes, HQ Program Element

Brief Summary of Relevant Information (major permit conditions, status of compliance or unusual problems):

Approval of this Notice of Construction allows active ventilation, via the use of a portable exhauster, on the 241-A-101 tank during salt well pumping and other routine activities performed at the tank. Major permit conditions include limits on volatile organic carbon emission rates and opacity. During the period covered by this Status Report, the portable exhauster proceeded with no compliance issues.

Prepared by: Westinghouse Hanford Company

Date: July 31,1996

Environmental Services 
The following information was prepared in response to requirements of DOE Order 5400.2A.

DOE Operations Office: Richland

DOE Facility: Hanford Site

Existing Permit (X) $\quad$ Renewal ( ) New Permit ( )

Permit Type: Radioactive Air Emissions Program Notice of Construction - WAC 246-247

Permitting Agency: State of Washington Department of Health

Permit Number: AIR-94-502

Permitted Unit: Tank 241-AZ-101 Waste Retrieval and 241-AY/241-AZ Tank Farms

Ventilation Upgrades, Project W-151 and Project W-030

Issuance Date: May 5, 1994

Expiration Date: N/A

Need for Headquarters' Action

Yes ( ) No (X)

(for permit renewals or new permits)

If yes, HQ Program Element

Brief Summary of Relevant Information (major permit conditions, status of compliance or unusual problems):

Approval of this Notice of Construction allows the installation and operation of mixer pumps in the 241-AZ-101 tank (an existing double-shell tank) using approved radionuclide air emissions control equipment in accordance with descriptions contained in the application. Project W-151 demonstrates techniques to be used for future retrieval activities. Project W-030 provides ventilation upgrades in the 24I-AY/241-AZ Tank Farms. Both tank farms are ventilated through the same ventilation system. During the period covered by this Status Report, these projects proceeded with no compliance issues.

A request to remove the continuous monitoring for iodine and tritium, as specified in the Notice of Construction, was approved on July 10, 1996. A notification of emission changes was submitted on June 26,1996 , for the planned testing of the mixer pumps before the completion of the ventilation upgrades. A response to this submittal is pending.

Prepared by: Westinghouse Hanford Company

Date: July 31,1996 Environmental Services 
The following information was prepared in response to requirements of DOE Order 5400.2A.

DOE Operations Office: Richland

DOE Facility: Hanford Site

Existing Permit (X) Renewal ( ) New Permit ( )

Permit Type: National Emission Standard for Hazardous Air Pollutants (NESHAPs) 40 CFR 61, Subpart H

Permitting Agency: U.S. Environmental Protection Agency, Region 10

Permit Number: N/A

Permitted Unit: Tank 241-AZ-101 Waste Retrieval and 241-AY/241-AZ Tank Farms Ventilation Upgrades, Project W-151 and Project W-030

Issuance Date: March 15, 1994

Expiration Date: N/A

Need for Headquarters' Action

(for permit renewals or new permits)
Yes ( ) No (X)

If yes, HQ Program Element

Brief Summary of Relevant Information (major permit conditions, status of compliance or unusual problems):

Approval of this application allows the installation and operation of mixer pumps in the 241-AZ-101 tank (an existing double-shell tank) using approved radionuclide air emissions control equipment in accordance with descriptions contained in the application. Project W-151 demonstrates techniques to be used for future retrieval activities. Project W- 030 provides ventilation upgrades in the 241-AY/241-AZ Tank Farms. Both tank farms are ventilated through the same ventilation system. During the period covered by this Status Report, these projects proceeded with no compliance issues.

A request to remove the continuous monitoring for iodine and tritium, as specified in the Notice of Construction, was approved on September 3, 1996. A notification of emission changes was submitted on June 26, 1996, for the planned testing of the mixer pumps before the completion of the ventilation upgrades. A response to this submittal is pending.

Prepared by: Westinghouse Hanford Company

Date: July 31, 1996

Environmental Services 
The following information was prepared in response to requirements of DOE Order 5400.2A.

DOE Operations Office: Richland

DOE Facility: Hanford Site

Existing Permit (X) Renewal ( ) New Permit ( )

Permit Type: Notice of Construction for:

General Regulations for Air Pollution Sources - WAC 173-400

Controls for New Sources of Toxic Air Pollutants - WAC 173-460

Permitting Agency: Washington State Department of Ecology

Permit Number: NOC-94-07

Permitted Unit: Tank 241-AZ-101 Waste Retrieval and 241-AY/241-AZ Tank Farms Ventilation Upgrades, Project W-151 and Project W-030

Issuance Date: August 26, 1994

Expiration Date: N/A

Need for Headquarters' Action Yes ( ) No (X)

(for permit renewals or new permits)

If yes, HQ Program Element

Brief Summary of Relevant Information (major permit conditions, status of compliance or unusual problems):

Approval of this Notice of Construction allows the installation and operation of mixer pumps in the 241-AZ-101 tank (an existing double-shell tank) using approved radionuclide air emissions control equipment in accordance with descriptions contained in the application. Project W-151 demonstrates techniques to be used for future retrieval activities. Project W-030 provides ventilation upgrades in the 241-AY/241-AZ Tank Farms. Both tank farms are ventilated through the same ventilation system. During the period covered by this Status Report, these projects proceeded with no compliance issues.

On July 18 , 1996, a notification of emission changes was prepared for the planned testing of the mixer pumps before the completion of the ventilation upgrades. A response to this submittal is pending.

Prepared by: Westinghouse Hanford Company

Date: July 31,1996 Environmental Services 
The following information was prepared in response to requirements of DOE Order 5400.2A.

DOE Operations Office: Richland

DOE Facility: Hanford Site

Existing Permit ( ) Renewal ( ) New Permit (X)

Permit Type: Radioactive Air Emissions Program Notice of Construction - WAC 246-247

Permitting Agency: State of Washington Department of Health

Permit Number: Routine Technical Assistance Meeting

Permitted Unit: Tank 241-C-301 Catch Tank Vapor Space Sampling

Issuance Date: August 1995

Expiration Date: NA

Need for Headquarters' Action

(for permit renewals or new permits)
Yes ( ) No ( $X)$

If yes, HQ Program Element

Brief Summary of Relevant Information (major permit conditions, status of compliance or unusual problems):

Approval of this Notice of Construction allows the sampling of the first of many miscellaneous underground storage tanks. A specially fabricated, high-efficiency particulate air filtered, glove bag is to be employed to contain airborne emissions due to venting of the miscellaneous underground storage tanks. Each tank is to be resealed when the sampling is completed. At this time, approval is being sought only for sampling the 241-C-301 tank. This tank is part of an overall miscellaneous underground storage tank program that consists of approximately 128 tanks. The sampling activity for the 241-C-301 tank is completed and data collected will support the balance of sampling of the miscellaneous underground storage tanks. During the period covered by this Status Report, the vapor space sampling of the 241-C-301 tank proceeded with no compliance issues.

Prepared by: Westinghouse Hanford Company

Date: July 31, 1996

Environmental Services 
The following information was prepared in response to requirements of DOE Order 5400.2A.

DOE Operations Office: Richland

DOE Facility: Hanford Site

Existing Permit ( X) Renewal ( ) New Permit ( )

Permit Type: Radioactive Air Emissions Program Notice of Construction - WAC 246-247

Permitting Agency: State of Washington Department of Health

Permit Number: AIR 94-910

Permitted Unit: Tank 241-C-103 Organic Removal

Issuance Date: September 8, 1994

Expiration Date: N/A

Need for Headquarters' Action

$$
\text { Yes ( ) No (X) }
$$

(for permit renewals or new permits)

If yes, HQ Program Element

Brief Summary of Relevant Information (major permit conditions, status of compliance or unusual problems):

Approval of this Notice of Construction allows for the removal, separation, and storage of a floating layer of organics in the 241-C-103 tank in accordance with descriptions contained in the application. There are approximately 19 cubic meters (671 cubic feet) of organic waste involved. During the period covered by this Status Report, this project proceeded with no compliance issues.

Prepared by: Environmental Services

Date: July 31,1996

Westinghouse Hanford Company 
The following information was prepared in response to requirements of DOE Order 5400.2A.

DOE Operations Office: Richland

DOE Facility: Hanford Site

Existing Permit ( X) Renewal ( ) New Permit ( )

Permit Type: National Emission Standard for Hazardous Air Pollutants (NESHAPs) 40 CFR 61, Subpart H

Permitting Agency: U.S. Environmental Protection Agency, Region 10

Permit Number: N/A

Permitted Unit: Tank 241-C-103 Organic Removal

Issuance Date: August 31, 1994

Expiration Date: N/A

Need for Headquarters' Action

(for permit renewals or new permits)
Yes ( ) No (X)

If yes, HQ Program Element

Brief Summary of Relevant Information (major permit conditions, status of compliance or unusual problems):

Approval of this application allows for the removal, separation, and storage of a floating layer of organics in the 241-C-103 tank in accordance with descriptions contained in the application. There are approximately 19 cubic meters ( 671 cubic feet) of organic waste involved. During the period covered by this Status Report, this project proceeded with no compliance issues.

Prepared by: Westinghouse Hanford Company

Date: July 31,1996 Environmental Services 
The following information was prepared in response to requirements of DOE Order 5400.2A.

DOE Operations Office: Richland

DOE Facility: Hanford Site

Existing Permit ( ) Renewal ( ) New Permit (X)

Permit Type: Radioactive Air Emissions Program Notice of Construction - WAC 246-247

Permitting Agency: State of Washington Department of Health

Permit Number: AIR 95-712

Permitted Unit: Tank 241-C-106 Sluicing, Project W-320

Issuance Date: July 31, 1995

Expiration Date: N/A

Need for Headquarters' Action

(for permit renewals or new permits)
Yes ( ) No (X)

If yes, HQ Program Element

Brief Summary of Relevant Information (major permit conditions, status of compliance or unusual problems):

Approval of this Notice of Construction allows construction and operation of the 241-C-106 tank waste retrieval system in accordance with descriptions contained in the application. The 241-C-106 tank is a high-heat watchlist single-shell tank. This high-heat waste tank requires the addition of water to cool the tank waste. Retrieval of the waste eliminates the need to add water to the tank. Two phases of permitting were pursued. Phase I approval, received from the Department of Health on February 28, 1994 (AIR-94-214), did not involve radioactive air emissions. The remaining Phase II activities generate radioactive air emissions, which required the submittal of a Notice of Construction. During the period covered by this Status Report, this project operated with no compliance issues.

Prepared by: Westinghouse Hanford Company

Date: July 31, 1996

Environmental Services 
The following information was prepared in response to requirements of DOE Order 5400.2A.

DOE Operations Office: Richland

DOE Facility: Hanford Site

Existing Permit (X) Renewal ( ) New Permit ( )

Permit Type: National Emission Standard for Hazardous Air Pollutants (NESHAPs) 40 CFR 61, Subpart H

Permitting Agency: U.S. Environmental Protection Agency, Region 10

Permit Number: 194-RPS-254

Permitted Unit: Tank 241-C-106 Sluicing, Project W-320

Issuance Date: February 23, 1994

Expiration Date: N/A

Need for Headquarters' Action

(for permit renewals or new permits)
Yes ( ) No (X)

If yes, HQ Program Element

Brief Summary of Relevant Information (major permit conditions, status of compliance or unusual problems):

Approval of this application allows construction and operation of the 241-C-106 tank waste retrieval system in accordance with descriptions contained in the application. The 241-C-106 tank is a high-heat watchlist single-shell tank. This high-heat waste tank requires the addition of water to cool the tank waste. Retrieval of the waste eliminates the need to add water to the tank. During the period covered by this Status Report, this project operated with no compliance issues.

Prepared by: Westinghouse Hanford Company

Date: July 31, 1996

Environmental Services 
The following information was prepared in response to requirements of DOE Order 5400.2A.

DOE Operations Office: Richland

DOE Facility: Hanford Site

Existing Permit ( ) Renewal ( ) New Permit (X)

Permit Type: Notice of Construction for:

General Regulations for Air Pollution Sources - WAC 173-400

Controls for New Sources of Toxic Air Pollutants - WAC 173-460

Permitting Agency: Washington State Department of Ecology

Permit Number: NWP 95(7) C-106

Permitted Unit: Tank 241-C-106 Sluicing, Project W-320

Issuance Date: October 6, 1995

Expiration Date: TBD

Need for Headquarters' Action

(for permit renewals or new permits)
Yes ( ) No (X)

If yes, HQ Program Element

Brief Summary of Relevant Information (major permit conditions, status of compliance or unusual problems):

Approval of this Notice of Construction allows construction and operation of the 241-C-106 tank waste retrieval system using approved nonradionuclide air emissions control equipment. The 241-C-106 tank is a high-heat watchlist single-shell tank. This high-heat waste tank requires the addition of water to cool the tank waste. Retrieval of the waste eliminates the need to add water to the tank. Two phases of permitting were pursued. Phase I did not involve radioactive air emissions, and Ecology indicated that written approval for Phase I was not required. The remaining major permit conditions include initial compliance demonstration for volatile organic compounds and no visible emissions with respect to particulate matter less than 10 microns criteria pollutant. Phase II activities generate radioactive air emissions, which required the submittal of a Notice of Construction. 
The following information was prepared in response to requirements of DOE Order 5400.2A.

DOE Operations Office: Richland

DOE Facility: Hanford Site

Existing Permit (X) Renewal ( ) New Permit ( )

Permit Type: Radioactive Air Emissions Program Notice of Construction - WAC 246-247

Permitting Agency: State of Washington Department of Health

Permit Number: AIR-95-1004

Permitted Unit: Tank Farm 241-S Removal of Duct Work and Associated Exhausters

Issuance Date: October 12, 1995

Expiration Date: N/A

Need for Headquarters' Action

(for permit renewals or new permits)

\section{Yes ( ) No (X)}

If yes, HQ Program Element

Brief Summary of Relevant Information (major permit conditions, status of compliance or unusual problems):

Approval of this Notice of Construction allows the dismantling, size reduction, and packaging for disposal of duct work and associated exhausters at the 241-S Tank Farm in accordance with descriptions contained in the application. During the period covered by this Status Report, this project proceeded with no compliance issues.

Prepared by: Westinghouse Hanford Company

Date: July 31, 1996 Environmental Services 
The following information was prepared in response to requirements of DOE Order $5400.2 \mathrm{~A}$.

DOE Operations Office: Richland

DOE Facility: Hanford Site

Existing Permit ( ) Renewal ( ) New Permit (X)

Permit Type: National Emission Standard for Hazardous Air Pollutants (NESHAPs) 40 CFR 61, Subpart H

Permitting Agency: U.S. Environmental Protection Agency, Region 10

Permit Number: N/A

Permitted Unit: Tank Farm 241-S Removal of Duct Work and Associated Exhausters

Issuance Date: September 20, 1995

Expiration Date: N/A

Need for Headquarters' Action

(for permit renewals or new permits)

Yes ( ) No (X)

If yes, HQ Program Element

Brief Summary of Relevant Information (major permit conditions, status of compliance or unusual problems):

Approval of this application allows the dismantling, size reduction, and packaging for disposal of duct work and associated exhausters at the 241-S Tank Farm in accordance with descriptions contained in the application. During the period covered by this Status Report, this project proceeded with no compliance issues.

Prepared by: Westinghouse Hanford Company

Date: July 31, 1996

Environmental Services 
The following information was prepared in response to requirements of DOE Order 5400.2A.

DOE Operations Office: Richland

DOE Facility: Hanford Site

Existing Permit (X) Renewal ( ) New Permit ( )

Permit Type: Radioactive Air Emissions Program Notice of Construction - WAC 246-247

Permitting Agency: State of Washington Department of Health

Permit Number: AIR 95-203

Permitted Unit: Tank 241-SY-101 Mixer Pump Replacement

Issuance Date: February 21, 1995

Expiration Date: N/A

Need for Headquarters' Action

Yes ( ) No (X)

(for permit renewals or new permits)

If yes, HQ Program Element

Brief Summary of Relevant Information (major permit conditions, status of compliance or unusual problems):

Approval of this Notice of Construction allows replacement of the present 241-SY-101 Mixer Pump, if the current pump fails, in accordance with descriptions contained in the application. The mixer pump is designed to mitigate flammable gas buildup in the 241-SY-101 tank. During the period covered by this Status Report, the 241-SY-101 Mixer Pump operated with no compliance issues.

Prepared by: Westinghouse Hanford Company

Date: July 31, 1996

Environmental Services 
The following information was prepared in response to requirements of DOE Order 5400.2A.

DOE Operations Office: Richland

DOE Facility: Hanford Site

Existing Permit (X) Renewal ( ) New Permit ( )

Permit Type: National Emission Standard for Hazardous Air Pollutants (NESHAPs) 40 CFR 61, Subpart H

Permitting Agency: U.S. Environmental Protection Agency, Region 10

Permit Number: N/A

Permitted Unit: Tank 241-SY-101 Mixer Pump Replacement

Issuance Date: February 14, 1995

Expiration Date: N/A

Need for Headquarters' Action

(for permit renewals or new permits)
Yes ( ) No (X)

If yes, HQ Program Element

Brief Summary of Relevant Information (major permit conditions, status of compliance or unusual problems):

Approval of this application allows replacement of the present 241-SY-101 Mixer Pump, if the current pump fails, in accordance with descriptions contained in the application. The mixer pump is designed to mitigate flammable gas buildup in the 241-SY-101 tank. During the period covered by this Status Report, the 241-SY-101 Mixer Pump operated with no compliance issues.

Prepared by: Westinghouse Hanford Company

Date: July 31, 1996 Environmental Services 
The following information was prepared in response to requirements of DOE Order 5400.2A.

DOE Operations Office: Richland

DOE Facility: Hanford Site

Existing Permit ( ) Renewal ( ) New Permit (X)

Permit Type: Radioactive Air Emissions Program Notice of Construction - WAC 246-247

Permitting Agency: State of Washington Department of Health

Permit Number: Routine Technical Assistance Meeting

Permitted Unit: Tank Farm Routine Activities Updated

Issuance Date: September 1995

Expiration Date: NA

Need for Headquarters' Action

Yes ( ) No (X)

(for permit renewals or new permits)

If yes, $\mathrm{HQ}$ Program Element

Brief Summary of Relevant Information (major permit conditions, status of compliance or unusual problems):

Approval of this Notice of Construction allows the addition of new routine tank farm activities to the list of approved routine activities. During the period covered by this Status Report, these routine activities proceeded with no compliance issues.

Prepared by: Westinghouse Hanford Company

Date: July 31, 1996

Environmental Services 
The following information was prepared in response to requirements of DOE Order 5400.2A.

DOE Operations Office: Richland

DOE Facility: Hanford Site

Existing Permit ( ) Renewal ( ) New Permit (X)

Permit Type: Radioactive Air Emissions Program Notice of Construction - WAC 246-247

Permitting Agency: State of Washington Department of Health

Permit Number: Routine Technical Assistance Meeting

Permitted Unit: T Plant Long-Length Contaminated Equipment Grouting and Microencapsulation

Issuance Date: June 1996

Expiration Date: NA

Need for Headquarters' Action

(for permit renewals or new permits)
Yes ( ) No (X)

If yes, HQ Program Element

Brief Summary of Relevant Information (major permit conditions, status of compliance or unusual problems):

Approval of this Notice of Construction allows the grouting and microencapsulation of long-length contaminated equipment at T Plant. This process involves the packaging of failed equipment, etc., and grouting the void space in the package. During the period covered by this Status Report, this activity proceeded with no compliance issues.

Prepared by: Westinghouse Hanford Company

Date: July 31, 1996 Environmental Services 
The following information was prepared in response to requirements of DOE Order $5400.2 \mathrm{~A}$.

DOE Operations Office: Richland

DOE Facility: Hanford Site

Existing Permit ( ) Renewal ( ) New Permit (X)

Permit Type: Radioactive Air Emissions Program Notice of Construction — WAC 246-247

Permitting Agency: State of Washington Department of Health

Permit Number: Routine Technical Assistance Meeting

Permitted Unit: T Plant Secondary Containment and Leak Detection Upgrades, Project W-259

Issuance Date: June 1996

Expiration Date: NA

Need for Headquarters' Action

(for permit renewals or new permits)
Yes ( ) No (X)

If yes, HQ Program Element

Brief Summary of Relevant Information (major permit conditions, status of compliance or unusual problems):

Approval of this Notice of Construction allows secondary containment and leak detection upgrades to be initiated at $\mathrm{T}$ Plant. The results of the non-destructive assessment of the 2706-T high-efficiency particulate air filter bank confirmed that the associated stack represented a nondesignated stack ( $<0.1$ mil-rem per year potential-to-emit). During the period covered by this Status Report, this activity proceeded with no compliance issues.

Prepared by: Westinghouse Hanford Company

Date: July 31, 1996

Environmental Services 
The following information was prepared in response to requirements of DOE Order 5400.2A.

DOE Operations Office: Richland

DOE Facility: Hanford Site

Existing Permit ( ) Renewal ( ) New Permit (X)

Permit Type: Radioactive Air Emissions Program Notice of Construction - WAC 246-247

Permitting Agency: State of Washington Department of Health

Permit Number: N/A

Permitted Unit: Transfer and Receipt of Waste in the 324 Building for Storage in PUREX Storage Tunnel Number 2

Issuance Date: December 4, 1995

Expiration Date: $\mathrm{N} / \mathrm{A}$

Need for Headquarters' Action

(for permit renewals or new permits)
Yes ( ) No (X)

If yes, HQ Program Element

Brief Summary of Relevant Information (major permit conditions, status of compliance or unusual problems):

Approval of this Notice of Construction allows activities to proceed to safely containerize, transport, and store waste from the 324 Building in the PUREX Storage Tunnel Number 2 in accordance with descriptions contained in the application. During the period covered by this Status Report, this activity proceeded with no compliance issues.

Prepared by: Westinghouse Hanford Company

Date: July 31, 1996

Environmental Services 
The following information was prepared in response to requirements of DOE Order 5400.2A.

DOE Operations Office: Richland

DOE Facility: Hanford Site

Existing Permit ( ) Renewal ( ) New Permit (X)

Permit Type: National Emission Standard for Hazardous Air Pollutants (NESHAPs) 40 CFR 61, Subpart H

Permitting Agency: U.S. Environmental Protection Agency, Region 10

Permit Number: N/A

Permitted Unit: Transfer and Receipt of Waste in the 324 Building for Storage in PUREX

Storage Tunnel Number 2

Issuance Date: December 6, 1995

Expiration Date: N/A

Need for Headquarters' Action

(for permit renewals or new permits)
Yes ( ) No (X)

If yes, HQ Program Element

Brief Summary of Relevant Information (major permit conditions, status of compliance or unusual problems):

Approval of this application allows activities to proceed to safely containerize, transport, and store waste from the 324 Building in the PUREX Storage Tunnel Number 2 in accordance with descriptions contained in the application. During the period covered by this Status Report, this activity proceeded with no compliance issue

Prepared by: Westinghouse Hanford Company

Date: July 31, 1996 Environmental Services 
The following information was prepared in response to requirements of DOE Order 5400.2A.

DOE Operations Office: Richland

DOE Facility: Hanford Site

Existing Permit ( ) Renewal ( ) New Permit (X)

Permit Type: Radioactive Air Emissions Program Notice of Construction - WAC 246-247

Permitting Agency: State of Washington Department of Health

Permit Number: Routine Technical Assistance Meeting

Permitted Unit: UP-1 Groundwater Processing in the 200 Area Effluent Treatment Facility

Issuance Date: June 1996

Expiration Date: NA

Need for Headquarters' Action

(for permit renewals or new permits)

$$
\text { Yes ( ) No (X) }
$$

If yes, HQ Program Element

Brief Summary of Relevant Information (major permit conditions, status of compliance or unusual problems):

Approval of this Notice of Construction allows an additional waste stream from the UP-1 Groundwater to be treated at the 200 Area Effluent Treatment Facility. Because the 100-N Basin water processing and the UP-1 Groundwater processing presented sequential potentials-to-emit to the environment, the combined potential-to-emit was calculated at 2E-02 mili-rem per-year total effective dose equivalent. During the period covered by this Status Report, these activities proceeded with no compliance issues.

Prepared by: Westinghouse Hanford Company

Date: July 31,1996 Environmental Services 
The following information was prepared in response to requirements of DOE Order 5400.2A.

DOE Operations Office: Richland

DOE Facility: Hanford Site

Existing Permit (X) Renewal ( ) New Permit ( )

Permit Type: Radioactive Air Emissions Program Notice of Construction - WAC 246-247

Permitting Agency: State of Washington Department of Health

Permit Number: AIR-93-907

Permitted Unit: Waste Receiving and Processing I

Issuance Date: September 7, 1993

Expiration Date: Expires if work is interrupted for $>18$ months

Need for Headquarters' Action

(for permit renewals or new permits)

$$
\begin{aligned}
& \text { Yes ( ) No (X) } \\
& \text { If yes, HQ Program Element }
\end{aligned}
$$

Brief Summary of Relevant Information (major permit conditions, status of compliance or unusual problems):

Approval of this Notice of Construction allows construction of Waste Receiving and Processing I using approved radionuclide air emissions control equipment (Tri-Party Agreement Milestones M-18-00 and M-18-01). The Waste Receiving and Processing I is permitted to examine, assay, characterize, treat, and repackage radioactive and mixed waste. During the period covered by this Status Report, these Waste Receiving and Processing I activities proceeded with no compliance issues.

Prepared by: Westinghouse Hanford Company

Date: July 31,1996 Environmental Services 
The following information was prepared in response to requirements of DOE Order 5400.2A.

DOE Operations Office: Richland

DOE Facility: Hanford Site

Existing Permit ( X ) Renewal ( ) New Permit ( )

Permit Type: National Emission Standards for Hazardous Air Pollutants (NESHAPs) 40 CFR 61, Subpart H

Permitting Agency: U.S. Environmental Protection Agency, Region 10

Permit Number: N/A

Permitted Unit: Waste Receiving and Processing I

Issuance Date: May 10, 1993

Expiration Date: Expires if work is interrupted for $>18$ months

Need for Headquarters' Action

(for permit renewals or new permits)
Yes ( ) No (X)

If yes, HQ Program Element

Brief Summary of Relevant Information (major permit conditions, status of compliance or unusual problems):

Approval of this application allows construction of Waste Receiving and Processing I using approved radionuclide air emissions control equipment (Tri-Party Agreement Milestones M-18-00 and M-18-01). Waste Receiving and Processing I is permitted to examine, assay, characterize, treat, and repackage radioactive and mixed waste. During the period covered by this Status Report, these Waste Receiving and Processing I activities proceeded with no compliance issues.

Prepared by: Westinghouse Hanford Company

Date: July 31, 1996

Environmental Services 
The following information was prepared in response to requirements of DOE Order $5400.2 \mathrm{~A}$.

DOE Operations Office: Richland

DOE Facility: Hanford Site

Existing Permit (X) Renewal ( ) New Permit ( )

Permit Type: Notice of Construction for:

General Regulations for Air Pollution Sources - WAC 173-400

Controls for New Sources of Toxic Air Pollutants - WAC 173-460

Permitting Agency: Washington State Department of Ecology

Permit Number: NOC-93-05

Permitted Unit: Waste Receiving and Processing I

Issuance Date: December 19, 1993

Expiration Date: N/A

Need for Headquarters' Action

(for permit renewals or new permits)
Yes ( ) No (X)

If yes, HQ Program Element

Brief Summary of Relevant Information (major permit conditions, status of compliance or unusual problems):

Approval of this Notice of Construction allows construction of the Waste Receiving and Processing I using approved radionuclide air emissions control equipment (Tri-Party Agreement Milestones M-18-00 and M-18-01). The Waste Receiving and Processing I is permitted to examine, assay, characterize, treat, and repackage radioactive and mixed waste. During the period covered by this Status Report, these Waste Receiving and Processing I activities proceeded with no compliance issues.

Prepared by: Westinghouse Hanford Company

Date: July 31, 1996

Environmental Services 
The following information was prepared in response to requirements of DOE Order 5400.2A.

DOE Operations Office: Richland

DOE Facility: Hanford Site

Existing Permit ( ) Renewal ( ) New Permit (X)

Permit Type: Radioactive Air Emissions Program Notice of Construction — WAC 246-247

Permitting Agency: State of Washington Department of Health

Permit Number: Routine Technical Assistance Meeting

Permitted Unit: Waste Receiving and Processing 1 Stack No. 296-W-004 Monitoring System Modifications

Issuance Date: July 1996

Expiration Date: NA

Need for Headquarters' Action

(for permit renewals or new permits)
Yes ( ) No (X)

If yes, HQ Program Element

Brief Summary of Relevant Information (major permit conditions, status of compliance or unusual problems):

Approval of this Notice of Construction allows a revision to the Waste Receiving and Processing I effluent monitoring system. Instead of using two separate continuous air monitors, one will be used that will measure both alpha and beta emitting particles. Also, filter media will be changed reflecting a greater collection efficiency to $>99$ percent for 0.3 micron. During the period covered by this Status Report, this change in the monitoring system proceeded with no compliance issues.

Prepared by: Westinghouse Hanford Company

Date: July·31, 1996 Environmental Services 
The following information was prepared in response to requirements of DOE Order 5400.2A.

DOE Operations Office: Richland

DOE Facility: Hanford Site

Existing Permit (X) Renewal ( ) New Permit ( )

Permit Type: Radioactive Air Emissions Program Notice of Construction - W WC 246-247

Permitting Agency: State of Washington Department of Health

Permit Number: EPS-90-275

Permitted Unit: Waste Sampling and Characterization Facility

Issuance Date: June 11, 1990

Expiration Date: N/A

Need for Headquarters' Action

Yes ( ) No (X)

(for permit renewals or new permits)

If yes, HQ Program Element

Brief Summary of Relevant Information (major permit conditions, status of compliance or unusual problems):

Approval of this Notice of Construction allows construction of the Waste Sampling and Characterization Facility in the 600 Area using approved radionuclide air emissions control equipment in accordance with descriptions contained in the application. The Waste Sampling and Characterization Facility provides the sample analyses necessary to support remediation on the Hanford Site. No revisions of this Notice of the Construction have been submitted to the Department of Health. During the period covered by this Status Report, the Waste Sampling and Characterization Facility operated with no compliance issues.

Prepared by: Westinghouse Hanford Company

Date: July 31, 1996

Environmental Services 
The following information was prepared in response to requirements of DOE Order 5400.2A.

DOE Operations Office: Richland

DOE Facility: Hanford Site

Existing Permit (X) Renewal ( ) New Permit ( )

Permit Type: Notice of Construction for:

General Regulations for Air Pollution Sources - WAC 173-400

Controls for New Sources of Toxic Air Pollutants - WAC 173-460

Permitting Agency: Washington State Department of Ecology

Permit Number: N/A

Permitted Unit: Waste Sampling and Characterization Facility

Issuance Date: September 17, 1990

Expiration Date: N/A

Need for Headquarters' Action

(for permit renewals or new permits)
Yes ( ) No (X)

If yes, HQ Program Element

Brief Summary of Relevant Information (major permit conditions, status of compliance or unusual problems):

Approval of this Notice of Construction allows construction of the Waste Sampling and Characterization Facility in the 600 Area using approved nonradionuclide air emissions control equipment. The Waste Sampling and Characterization Facility provides the sample analyses necessary to support remediation on the Hanford Site. No revisions of the Notice of Construction have been submitted to Ecology. No approval conditions were specified. During the period covered by this Status Report, the Waste Sampling and Characterization Facility operated with no compliance issues.

Prepared by: Westinghouse Hanford Company

Date: July 31, 1996 Environmental Services 
The following information was prepared in response to requirements of DOE Order $5400.2 \mathrm{~A}$.

DOE Operations Office: Richland

DOE Facility: Hanford Site

Existing Permit ( ) Renewal ( ) New Permit (X)

Permit Type: Notice of Construction for:

General Regulations for Air Pollution Sources - WAC 173-400

Permitting Agency: Washington State Department of Ecology

Permit Number: NWP-95-300/324 Lab

Permitted Unit: Waste Technology Engineering Laboratory, 324 Building

Issuance Date: August 18, 1995

Expiration Date: $\mathrm{N} / \mathrm{A}$

Need for Headquarters' Action

(for permit renewals or new permits)
Yes ( ) No (X)

If yes, HQ Program Element

Brief Summary of Relevant Information (major permit conditions, status of compliance or unusual problems):

Approval of this Notice of Construction allows renovation of the Waste Technology Engineering Laboratory (324 Building) in the 300 Area. This includes modernization of the Zone III exhaust ventilation system and selected laboratories serviced by the affected exhaust system. During the period covered by this Status Report, this activity proceeded with no compliances issues.

Prepared by: Pacific Northwest National Laboratory

Date: July 31, 1996

Environmental Compliance 
The following information was prepared in response to requirements of DOE Order 5400.2A.

DOE Operations Office: Richland

DOE Facility: Hanford Site

Existing Permit (X) Renewal ( ) New Permit ( )

Permit Type: Radioactive Air Emissions Program Notice of Construction - WAC 246-247

Permitting Agency: State of Washington Department of Health

Permit Number: Routine Technical Assistance Meeting

Permitted Unit: Waste Encapsulation and Storage Facility K-3 Duct Characterization and Washdown

Issuance Date: April 18, 1995

Expiration Date: N/A

Need for Headquarters' Action

(for permit renewals or new permits)
Yes ( ) No (X)

If yes, HQ Program Element

Brief Summary of Relevant Information (major permit conditions, status of compliance or unusual problems):

Approval of this Notice of Construction allows the Waste Encapsulation and Storage Facility K-3 duct characterization and washdown in accordance with descriptions contained in the application. The approval was for the radiological characterization of the K-3 ductwork. The plan uses a water rinse to clean (wash) less that 61 meters ( 200 feet) of ductwork upstream of the moisture separators and high-efficiency particulate air filters, after characterization. During the period covered by this Status Report, this activity proceeded with no compliance issues.

Prepared by: Westinghouse Hanford Company

Date: July 31, 1996 Environmental Services 
The following information was prepared in response to requirements of DOE Order $5400.2 \mathrm{~A}$.

DOE Operations Office: Richland

DOE Facility: Hanford Site

Existing Permit ( ) Renewal ( ) New Permit (X)

Permit Type: National Emission Standards for Hazardous Air Pollutants (NESHAPs) 40 CFR 61, Subpart H

Permitting Agency: U.S. Environmental Protection Agency, Region 10

Permit Number: N/A

Permitted Unit: Waste Encapsulation and Storage Facility K-3 Duct Characterization and Washdown

Issuance Date: April 27, 1995

Expiration Date: N/A

Need for Headquarters' Action

(for permit renewals or new permits)
Yes ( ) No ( $X)$

If yes, $\mathrm{HQ}$ Program Element

Brief Summary of Relevant Information (major permit conditions, status of compliance or unusual problems):

Approval of this application allows the Waste Encapsulation and Storage Facility K-3 duct characterization and washdown in accordance with descriptions contained in the application. The approval was for the radiological characterization of the K-3 ductwork. The plan uses a water rinse to clean (wash) less that 61 meters (200 feet) of ductwork upstream of the moisture separators and high-efficiency particulate air filters, after characterization. During the period covered by this Status Report, this activity proceeded with no compliance issues.

Prepared by: Westinghouse Hanford Company

Date: July 31,1996

Environmental Services 
DOE/RL-96-63, Rev. 0

$10 / 96$

This page intentionally left blank. 


\section{CLEAN WATER ACT PERMITTING}


DOE/RL-96-63, Rev. 0

$10 / 96$

This page intentionally left blank. 
The following information was prepared in response to requirements of DOE Order 5400.2A.

DOE Operations Office: Richland

DOE Facility: Hanford Site

Existing Permit (X) Renewal ( ) New Permit ( )

Permit Type: National Pollutant Discharge Elimination System (NPDES) - 40 CFR 122

Permitting Agency: U.S. Environmental Protection Agency, Region 10

Permit Number: WA-000374-3

Permitted Unit: 004A Outfall

Issuance Date: December 12, 1981

Expiration Date: Refer to Note

Need for Headquarters' Action

(for permit renewals or new permits)

Yes ( ) No (X)

If yes, HQ Program Element

Brief Summary of Relevant Information (major permit conditions, status of compliance or unusual problems):

The NPDES governs discharges to the Columbia River. The major permit conditions include discharge points, effluent limitations, and monitoring requirements.

The $100 \mathrm{~K}$ Pools are planned for fish rearing by the Yakima Indian Nation. A letter was sent to the EPA on August 1, 1996, identifying topics to discuss on NPDES permitting.

Note: The Hanford Site NPDES Permit expired December 31, 1985. Part 4, Subsection D, "General Requirements of the Federal Water Pollution Control Act," provides for a continuation of the existing NPDES permit in force until the EPA acts upon subsequent applications for renewal or modification. A renewal application was submitted to the EPA on June $28,1985$.

Prepared by: Westinghouse Hanford Company

Date: July 31, 1996

Environmental Services 
The following information was prepared in response to requirements of DOE Order 5400.2A.

DOE Operations Office: Richland

DOE Facility: Hanford Site

Existing Permit (X) Renewal ( ) New Permit ( )

Permit Type: National Pollutant Discharge Elimination System (NPDES) - 40 CFR 122

Permitting Agency: U.S. Environmental Protection Agency, Region 10

Permit Number: WA-000374-3

Permitted Unit: 013 A Outfall

Issuance Date: December 12, 1981

Expiration Date: Refer to Note

Need for Headquarters' Action

(for permit renewals or new permits)

\section{Yes ( ) No (X)}

If yes, HQ Program Element

Brief Summary of Relevant Information (major permit conditions, status of compliance or unusual problems):

The NPDES governs discharges to the Columbia River. The major permit conditions include discharge points, effluent limitations, and monitoring requirements.

A NPDES permit modification request for the increase in flow rate from the Aquaculture Laboratory and removal of the settleable solids parameter was submitted to the EPA in September 1992. No action has been taken by the EPA on the permit modification request for this NPDES permit.

Note: The Hanford Site NPDES Permit expired December 31, 1985. Part 4, Subsection D, "General Requirements of the Federal Water Pollution Control Act," provides for a continuation of the existing NPDES permit in force until the EPA acts upon subsequent applications for renewal or modification. A renewal application was submitted to the EPA on June 28, 1985.

Prepared by: Pacific Northwest National Laboratory

Date: July 31,1996 Environmental Compliance 
The following information was prepared in response to requirements of DOE Order $5400.2 \mathrm{~A}$.

DOE Operations Office: Richland

DOE Facility: Hanford Site

Existing Permit (X) Renewal ( ) New Permit ( )

Permit Type: Modification Request for the Hanford Site National Pollutant Discharge Elimination System (NPDES) Permit - 40 CFR 122

Permitting Agency: U.S. Environmental Protection Agency, Region 10

Permit Number: WA-000374-3

Permitted Unit: 005, 006, 007, 009, and N Springs Outfalls

Issuance Date: December 12, 1981

Expiration Date: Refer to Note

Need for Headquarters' Action (for permit renewals or new permits)
Yes ( ) No (X)

If yes, HQ Program Element

Brief Summary of Relevant Information (major permit conditions, status of compliance or unusual problems):

The NPDES governs discharges to the Columbia River. The major permit conditions include discharge points, effluent limitations, and monitoring requirements.

A request for minor modification to the NPDES permit to eliminate $005,006,007,009$, and N Springs Outfalls from the monitoring and reporting requirements was submitted to the EPA in August 1995. The outfalls are inactive and no longer permitted discharges.

Note: The Hanford Site NPDES Permit expired December 31, 1985. Part 4, Subsection D, "General Requirements of the Federal Water Pollution Control Act," provides for a continuation of the existing NPDES permit in force until the EPA acts upon subsequent applications for renewal or modification. A renewal application was submitted to the EPA on June 28, 1985.

Prepared by: Westinghouse Hanford Company

Date: July 31,1996

Environmental Services 
The following information was prepared in response to requirements of DOE Order 5400.2A.

DOE Operations Office: Richland

DOE Facility: Hanford Site

Existing Permit (X) Renewal ( ) New Permit ( )

Permit Type: National Pollutant Discharge Elimination System (NPDES) - 40 CFR 122

Permitting Agency: U.S. Environmental Protection Agency, Region 10

Permit Number: WA-002591-7

Permitted Unit: 300 Area Treated Effluent Disposal Facility, Project L-045H

Issuance Date: October 31, 1994

Expiration Date: November 1, 1999

Need for Headquarters' Action

Yes ( ) No (X)

(for permit renewals or new permits)

If yes, HQ Program Element

Brief Summary of Relevant Information (major permit conditions, status of compliance or unusual problems):

The NPDES governs discharges to the Columbia River. The major permit conditions include discharge points, effluent limitations, and monitoring requirements.

The NPDES permit allows treatment and disposal of the process effluent to the Columbia River from industrial and research operations in the 300 Area. The 300 Area Treated Effluent Disposal Facility commenced discharge on December 30, 1994, meeting Tri-Party Agreement Milestone M-17-09. A letter was submitted to the EPA on August 1, 1996, identifying areas in the permit which need to be discussed for possible modification. Compliance with the permit conditions has been maintained with exception of the exceedances of copper, total suspended solids, and zinc. The limits and exceedances are listed below:

\begin{tabular}{|l|c|c|c|}
\hline \multicolumn{1}{|c|}{ Permit Condition } & Permit Maximum Daily Limit (ug/L) & Date of Exceedance & Daily Amount (ug/L) \\
\hline Cyanide & 10.0 & $12 / 18 / 95$ & 14.0 \\
\hline Total Suspended Solids & 9,000 & $2 / 22 / 96$ & 11,000 \\
\hline Copper & 5.0 & $3 / 18 / 96$ & 5.4 \\
\hline Total Suspended Solids & 9,000 & $5 / 9 / 96$ & 10,000 \\
\hline Copper & 5.0 & $5 / 20 / 96$ & 5.3 \\
\hline Arsenic & 5.0 & $7 / 8 / 96$ & 11 \\
\hline
\end{tabular}

Note: The Hanford Site NPDES Permit expired December 31, 1985. Part 4, Subsection D, "General Requirements of the Federal Water Pollution Control Act," provides for a continuation of the existing NPDES permit in force until the EPA acts upon subsequent applications for renewal or modification. A renewal application was submitted to the EPA on June 28, 1985.

Prepared by: Westinghouse Hanford Company

Date: July 31, 1996

\section{Environmental Services}


The following information was prepared in response to requirements of DOE Order 5400.2A.

DOE Operations Office: Richland

DOE Facility: Hanford Site

Existing Permit ( $\mathrm{X}$ ) Renewal ( ) New Permit ( )

Permit Type: Storm Water General Permit, No.: WA-R-000-00F, National Pollutant Discharge Elimination System (NPDES) - 40 CFR 122

Permitting Agency: U.S. Environmental Protection Agency, Region 10

Permit Number: WA-R-00A17F

Permitted Unit: Hanford Site (Storm Water General Permit)

Issuance Date: April 1994

Expiration Date: September 9, 1997

Need for Headquarters' Action

(for permit renewals or new permits)
Yes ( ) No ( $\mathrm{X}$ )

If yes, HQ Program Element

Brief Summary of Relevant Information (major permit conditions, status of compliance or unusual problems):

The Storm Water General Permit governs storm water discharges to the Columbia River. This permit requires a report of significant leaks and spills to be compiled annually by October 1 , and to be certified by DOE-RL and maintained on file. This annual report, based on a storm water outfall survey, is scheduled to be completed October 1, 1996. A new Notice of Intent must be submitted to the EPA by September 7, 1996, for renewal of the existing permit.

Prepared by: Westinghouse Hanford Company

Date: July 31, 1996 Environmental Services 
The following information was prepared in response to requirements of DOE Order 5400.2A.

DOE Operations Office: Richland

DOE Facility: Hanford Site

Existing Permit ( ) Renewal ( ) New Permit (X)

Permit Type: Termination of Coverage Storm Water General Permit, No.: WA-R-10-00F, from Construction Activities, National Pollutant Discharge Elimination System (NPDES) - 40 CFR 122

Permitting Agency: U.S. Environmental Protection Agency Region 10

Permit Number: WA-R-10-000F

Permitted Unit: 300 Area Treated Effluent Disposal Facility, Project L-045H

Issuance Date: N/A

Expiration Date: N/A

Need for Headquarters' Action

(for permit renewals or new permits)
Yes ( ) No (X)

If yes, identify appropriate HQ

Program Element

Brief Summary of Relevant Information (major permit conditions, status of compliance or unusual problems):

The NPDES governs discharges to the Columbia River. The major permit conditions include discharge points, effluent limitations, and monitoring requirements.

A Notice of Termination of coverage was submitted to the EPA under this general permit on January 9, 1995, for the 300 Area Treated Effluent Disposal Facility outfall construction project, that was assigned permit number WA-R-10-A09F. There has not been any activity on this permit during the period covered by this Status Report.

Prepared by: Westinghouse Hanford Company

Date: July 31, 1996

Environmental Services 
The following information was prepared in response to requirements of DOE Order 5400.2A.

DOE Operations Office: Richland

DOE Facility: Hanford Site

Existing Permit (X) Renewal ( ) New Permit ( )

Permit Type: Clean Water Act, Section 404-33 CFR 330

Permitting Agency: U.S. Army Corps of Engineers

Permit Number: 95-1-00441

Permitted Unit: $181 \mathrm{~B} / \mathrm{C}$ and D Fish Screen Replacement

Issuance Date: May 24, 1995

Expiration Date: May 24, 1998

Need for Headquarters' Action

(for permit renewals or new permits)
Yes ( ) No (X)

If yes, identify appropriate HQ

Program Element

Brief Summary of Relevant Information (major permit conditions, status of compliance or unusual problems):

This permit allows for dredging operations in the waters of the United States.

The $181 \mathrm{~B} / \mathrm{C}$ potable water intake requires dredging in front of the intake structure in the Columbia River to install a new passive fish screen. The application was submitted to the U.S. Army Corps of Engineers on March 10, 1995, with the dredging scheduled for August 1995. A certification of compliance was submitted to the U.S. Army Corps of Engineers on August 2, 1996.

Prepared by: Westinghouse Hanford Company

Date: July 31, 1996

Environmental Services 
The following information was prepared in response to requirements of DOE Order 5400.2A.

DOE Operations Office: Richland

DOE Facility: Hanford Site

Existing Permit ( ) Renewal ( ) New Permit (X)

Permit Type: Industrial Waste Water Discharge Permit-40 CFR 403, and City of Richland-Ordinance 35-84

Permitting Agency: City of Richland Water and Waste Utilities

Permit Number: N/A

Permitted Unit: 300 Area Sanitary Sewer System

Issuance Date: N/A

Expiration Date: N/A

Need for Headquarters' Action

(for permit renewals or new permits)
Yes ( ) No $(X)$

If yes, HQ Program Element

Brief Summary of Relevant Information (major permit conditions, status of compliance or unusual problems):

The sanitary waste water from the 300 Area will be transported via a new pipeline to the city of Richland sanitary waste water system. The DOE-RL signed a modification to the contract with the city of Richland for utility services on April 26, 1994. The 300 Area Industrial Waste Water Permit Application was submitted to the city of Richland on June 16, 1995. The application was submitted to satisfy the city of Richland sanitary waste water system NPDES permit condition. In August 1995, the city of Richland determined that no permit was required.

Prepared by: Westinghouse Hanford Company

Date: July 31, 1996 Environmental Services 
The following information was prepared in response to requirements of DOE Order 5400.2A.

DOE Operations Office: Richland

DOE Facility: Hanford Site

Existing Permit ( ) Renewal ( ) New Permit (X)

Permit Type: Clean Water Act, Section $404-33$ CFR 330

Permitting Agency: U.S. Army Corps of Engineers

Permit Number: N/A

Permitted Unit: 315 Filter Backwash and 384 Ash Sluice Outfall, Project L-203

Issuance Date: N/A

Expiration Date: N/A

Need for Headquarters' Action

(for permit renewals or new permits)
Yes ( ) No ( $\mathrm{X}$ )

If yes, identify appropriate HQ

Program Element

Brief Summary of Relevant Information (major permit conditions, status of compliance or unusual problems):

This permit allows for dredging operations in the waters of the United States.

A Clean Water Act permit application was submitted on July 11, 1994, to allow construction of an outfall in the Columbia River in January through February 1995. Further research indicated that the ash sluice stream could not comply with the draft limitations without additional treatment. In January 1995, it was decided to cancel this permit application. The burners will remain on oil, eliminating the ash sluice stream. The filter backwash will be recycled from the existing lined pond back through a potable water treatment facility, ending the need for an outfall in the Columbia River. The U.S. Army Corps of Engineers issued a letter to DOE-RL on September 14, 1995, canceling the permit application.

Prepared by: Westinghouse Hanford Company

Date: July 31, 1996 Environmental Services 
The following information was prepared in response to requirements of DOE Order 5400.2A.

DOE Operations Office: Richland

DOE Facility: Hanford Site

Existing Permit ( ) Renewal ( ) New Permit (X)

Permit Type: Industrial Pretreatment Permit - 40 CFR 403 and City of Richland Ordinance 7-96

Permitting Agency: City of Richland, Water and Waste Utilities

Permit Number: CR-IU005

Permitted Unit: Environmental Molecular Science Laboratory

Issuance Date: TBD

Expiration Date: TBD

Need for Headquarters' Action

(for permit renewals or new permits)
Yes ( ) No (X)

If yes, HQ Program Element

Brief Summary of Relevant Information (major permit conditions, status of compliance or unusual problems):

Application has been made by the DOE-RL for an industrial waste water discharge permit for the Environmental Molecular Sciences Laboratory. The permit will allow the laboratory to discharge pollutants to the city of Richland's publically owned treatment works pursuant to certain effluent limitations and other conditions necessary to carry out the provisions of local, state, and federal law.

A draft Fact Sheet, which summarizes decisions made during the permitting process, has been prepared by the city of Richland and was submitted for review to the DOE-RL. Review comments on the draft Fact Sheet were prepared and submitted to the city of Richland on June 10,1996. It is anticipated that the city of Richland will issue a final permit for Environmental Molecular Sciences Laboratory by October 10, 1996.

Prepared by: Pacific Northwest National Laboratory

Date: July 31, 1996

Environmental Compliance 
DOE/RL-96-63, Rev. 0 $10 / 96$

NATIONAL PARK SERVICE REVIEW PERMITTING 
DOE/RL-96-63, Rev. 0

$10 / 96$

This page intentionally left blank. 
The following information was prepared in response to requirements of DOE Order $5400.2 \mathrm{~A}$.

DOE Operations Office: Richland

DOE Facility: Hanford Site

Existing Permit (X) Renewal ( ) New Permit ( )

Permit Type: U.S. Park Service Review - Public Law 100-605

Permitting Agency: U.S. Park Service

Permit Number: N/A

Permitted Unit: $181 \mathrm{~B} / \mathrm{C}$ and D Fish Screen Replacement

Issuance Date: April 11, 1995

Expiration Date: N/A

Need for Headquarters' Action

(for permit renewals or new permits)
Yes ( ) No (X)

If yes, HQ Program Element

Brief Summary of Relevant Information (major permit conditions, status of compliance or unusual problems):

The Hanford Reach of the Columbia River is under study for Wild and Scenic River designation by the National Park Service and all projects that could affect this designation are required to be reviewed and approved by the National Park Service.

A request for review was submitted to the National Park Service on March 29, 1995. Approval was granted on April 11, 1995. The 181 B/C and D Fish Screen Replacement was completed on May 24, 1996 and April 22, 1996, respectively.

Prepared by: Westinghouse Hanford Company

Date: July 31, 1996 Environmental Services 
DOE/RL-96-63, Rev. 0

$10 / 96$

This page intentionally left blank. 
DOE/RL-96-63, Rev. 0

$10 / 96$

\section{AQUATIC LANDS LEASE PERMITTING}


DOE/RL-96-63, Rev. 0 $10 / 96$

This page intentionally left blank. 
The following information was prepared in response to requirements of DOE Order 5400.2A.

DOE Operations Office: Richland

DOE Facility: Hanford Site

Existing Permit (X) Renewal ( ) New Permit ( )

Permit Type: Application to Lease Aquatic Lands - WAC 173-201

Permitting Agency: State of Washington Department of Natural Resources

Permit Number: $20-013357$

Permitted Unit: 300 Area Treated Effluent Disposal Facility, Project L-045H

Issuance Date: October 16, 1994

Expiration Date: October 15, 2024 (with 2 additional 10-year option periods)

Need for Headquarters' Action

(for permit renewals or new permits)
Yes ( ) No (X)

If yes, HQ Program Element

Brief Summary of Relevant Information (major permit conditions, status of compliance or unusual problems):

The 300 Area Treated Effluent Disposal Facility (Project L-045H) is designed to treat and dispose of the process effluent to the Columbia River from industrial and research operations in the 300 Area. An Aquatic Lands Lease allows placement of an outfall for discharge of the treated effluent on the bottom of the Columbia River. The Aquatic Lands Lease contains monitoring and notification requirements. During the period covered by this Status Report, compliance has been maintained with the lease.

Prepared by: Westinghouse Hanford Company

Date: July 31, 1996 Environmental Services 
DOE/RL-96-63, Rev. 0

10/96

This page intentionally left blank. 
DOE/RL-96-63, Rev. 0

$10 / 96$

\section{HYDRAULIC PROJECT APPROVAL PERMITTING}


DOE/RL-96-63, Rev. 0

10/96

This page intentionally left blank. 
The following information was prepared in response to requirements of DOE Order 5400.2A.

DOE Operations Office: Richland

DOE Facility: Hanford Site

Existing Permit ( ) Renewal ( ) New Permit (X)

Permit Type: Hydraulic Project Approval Application - WAC 220-110

Permitting Agency: State of Washington Department of Fish and Wildlife

Permit Number: Original: 00-A3722-02; Modified: 00-A3722-03

Permitted Unit: $181 \mathrm{~B} / \mathrm{C}$ and D Fish Screen Replacement

Issuance Date: Original: June 8, 1995; Modified: April 29, 1996

Expiration Date: Original: July 31, 1996; Modified: November 1, 1996

Need for Headquarters' Action

(for permit renewals or new permits)
Yes ( ) No (X)

If yes, HQ Program Element

Brief Summary of Relevant Information (major permit conditions, status of compliance or unusual problems):

The Hydraulic Project Approval governs construction work within the high water mark on all Washington State streams. The major project approval requirements prevent excess siltation of the stream and replacement of the riverine vegetation.

A Hydraulic Project Approval Application was submitted on March 20, 1995, to allow dredging in front of the $181 \mathrm{~B} / \mathrm{C}$ water intake structure in the Columbia River in August 1995, and installation of fish screens at $181 \mathrm{~B} / \mathrm{C}$ and $\mathrm{D}$ water intake structures. A request was submitted to the Department of Fish and Wildlife on April 19, 1996, to modify the Hydraulic Project Approval to include vacuuming of sediment from the interior of the 181-K East river pumping station forebay. The Department of Fish and Wildlife issued a modified Hydraulic Project Approval on April 29, 1996, to include the vacuuming of sediment. The $181 \mathrm{~B} / \mathrm{C}$ and D Fish Screen Replacement was completed on May 24, 1996 and April 22, 1996, respectively. The vacuuming of the sediment at the 181-K East forebay was completed on May 30. 1996.

Prepared by: Westinghouse Hanford Company

Date: July 31, 1996 Environmental Services 
The following information was prepared in response to requirements of DOE Order 5400.2A.

DOE Operations Office: Richland

DOE Facility: Hanford Site

Existing Permit ( ) Renewal ( ) New Permit (X)

Permit Type: Hydraulic Project Approval Application -- WAC 220-110

Permitting Agency: State of Washington Department of Fish and Wildlife

Permit Number: 00-B8412-01

Permitted Unit: 181-K East Fish Screen Replacement

Issuance Date: April 29, 1996

Expiration Date: January 31, 1997

Need for Headquarters' Action

(for permit renewals or new permits)

\section{Yes ( ) No (X)}

If yes, HQ Program Element

Brief Summary of Relevant Information (major permit conditions, status of compliance or unusual problems):

The Hydraulic Project Approval governs construction work within the high water mark on all Washington State streams. The major project approval requirements prevent excess siltation of the stream and replacement of the riverine vegetation.

A Hydraulic Project Approval Application was submitted on April 19, 1996, to allow vacuum dredging in the forebay of the 181-K East water intake structure. This Hydraulic Project Approval allows the diversion of water without installation of fish guards until the fuel has been removed from the $\mathrm{K}$ Basins in the 100 Area.

Prepared by: Westinghouse Hanford Company

Date: July 31, 1996 Environmental Services 
DOE/RL-96-63, Rev. 0

$10 / 96$

\section{WATER QUALITY STANDARDS MODIFICATION PERMITTING}


DOE/RL-96-63, Rev. 0

$10 / 96$

This page intentionally left blank. 
The following information was prepared in response to requirements of DOE Order 5400.2A.

DOE Operations Office: Richland

DOE Facility: Hanford Site

Existing Permit (X) Renewal ( ) New Permit ( )

Permit Type: Water Quality Standards Modification Order - WAC 173-201A

Permitting Agency: Washington State Department of Ecology

Permit Number: DE-95NM-024

Permitted Unit: $181 \mathrm{~B} / \mathrm{C}$ and D Fish Screen Replacement

Issuance Date: June 6, 1995

Expiration Date: August 31, 1995

Need for Headquarters' Action

(for permit renewals or new permits)
Yes ( ) No (X)

If yes, HQ Program Element

Brief Summary of Relevant Information (major permit conditions, status of compliance or unusual problems):

The Water Quality Standards Modification Request allows the relaxation of water quality standards on a short-term basis to allow construction in Washington State streams. Appropriate pollution control measures are taken to prevent pollution of the stream.

A Water Quality Standards Modification Request was submitted to Ecology on March 31, 1995, to allow dredging in the Columbia River in August 1995. The Order allowed the waster quality criteria to be modified for a limited period between August 1, 1995, and August 31, 1995. The dredging was completed in August 1995. The $181 \mathrm{~B} / \mathrm{C}$ and D Fish Screen Replacement was completed on May 24, 1996 and April 22, 1996, respectively.

Prepared by: Westinghouse Hanford Company

Date: July 31, 1996 Environmental Services 
The following information was prepared in response to requirements of DOE Order 5400.2A.

DOE Operations Office: Richland

DOE Facility: Hanford Site

Existing Permit ( ) Renewal ( ) New Permit (X)

Permit Type: Water Quality Standards Modification Order — WAC 173-201A

Permitting Agency: Washington State Department of Ecology

Permit Number: DE-96-NM-034

Permitted Unit: 181-K Fish Screen Replacement

Issuance Date: May 1, 1996

Expiration Date: September 1, 1996

Need for Headquarters' Action

(for permit renewals or new permits)

Yes ( ) No (X)

If yes, HQ Program Element

Brief Summary of Relevant Information (major permit conditions, status of compliance or unusual problems):

The Water Quality Standards Modification Request allows the relaxation of water quality standards on a short-term basis to allow construction in Washington State streams. Appropriate pollution control measures are taken to prevent pollution of the stream.

A Water Quality Standards Modification Request was submitted to Ecology on April 19, 1996, to allow vacuum dredging in the forebay of the 181-K East water intake structure. The Order allowed the water quality criteria to be modified for a limited period between May 1 and September 1, 1996. The fish screen replacement has been delayed until an evaluation of alternatives for obtaining potable water has been completed. This permit applies only to the vacuum dredging. The fish screen replacement does not require a Water Quality Standards Modification Permit.

Prepared by: Westinghouse Hanford Company

Date: July 31, 1996 Environmental Services 
DOE/RL-96-63, Rev. 0

$10 / 96$

STATE WASTE DISCHARGE PERMITTING 
DOE/RL-96-63, Rev. 0

$10 / 96$

This page intentionally left blank. 
The following information was prepared in response to requirements of DOE Order 5400.2A.

DOE Operations Office: Richland

DOE Facility: Hanford Site

Existing Permit ( ) Renewal ( ) New Permit (X)

Permit Type: State Waste Discharge Permit — WAC 173-216

Permitting Agency: Washington State Department of Ecology

Permit Number: ST 4507

Permitted Unit: 100-N Sewage Lagoon

Issuance Date: TBD

Expiration Date: TBD

Need for Headquarters' Action

(for permit renewals or new permits)
Yes ( ) No (X)

If yes, HQ Program Element

Brief Summary of Relevant Information (major permit conditions, status of compliance or unusual problems):

Ecology Consent Order DE 91NM-177 lists regulatory milestones for liquid effluent streams at the Hanford Site to comply with the permitting requirements of WAC 173-216 (State Waste Discharge Program) or WAC 173-218 (Washington Underground Injection Control Program) where applicable. As a result, a WAC 173-216 State Waste Discharge Permit application (document number DOE/RL-94-22, Rev. 0) was submitted for the 100-N Sewage Lagoon. The 100-N Sewage Lagoon receives sewage from facilities in the 100-N Area and from septic systems and holding tanks located across the Hanford Site. A Consent Order DE 91NM-177 milestone was satisfied with the submittal of the permit application to Ecology in June 1994. Ecology issued a public Notice of Application on May 29, 1995. Ecology proposed to proceed with the permit development and issuance of a final permit. The draft permit is scheduled to be issued for public comment and review in the Fall of 1996.

Prepared by: Westinghouse Hanford Company

Date: July 31, 1996 Environmental Services 
The following information was prepared in response to requirements of DOE Order 5400.2A.

DOE Operations Office: Richland

DOE Facility: Hanford Site

Existing Permit ( ) Renewal ( ) New Permit (X)

Permit Type: State Waste Discharge Permit - WAC 173-216

Permitting Agency: Washington State Department of Ecology

Permit Number: ST 4503

Permitted Unit: 183-N Backwash Discharge Pond

Issuance Date: TBD

Expiration Date: TBD

Need for Headquarters' Action

(for permit renewals or new permits)
Yes ( ) No (X)

If yes, HQ Program Element

Brief Summary of Relevant Information (major permit conditions, status of compliance or unusual problems):

Ecology Consent Order DE 91NM-177 lists regulatory milestones for liquid effluent streams at the Hanford Site to comply with the permitting requirements of WAC 173-216 (State Waste Discharge Program) or WAC 173-218 (Washington Underground Injection Control Program) where applicable. As a result, a WAC 173-216 State Waste Discharge Permit application (DOE/RL-94-23, Rev. 0) was submitted for the 183-N Filter Backwash Stream. The 183-N Filter Backwash Stream consists of waste water produced by backwashing the multimedia filter basins at the 183-N Water Treatment Facility. A Consent Order DE 9INM-177 milestone was satisfied with the submittal of the permit application to Ecology in June 1994. Ecology issued a public Notice of Application on May 29, 1995. Ecology proposed to proceed with permit development and issuance of a final permit. The draft permit is scheduled to be issued for public comment and review in the Fall of 1996.

Prepared by: Bechtel Hanford, Inc.

Date: July 31, 1996

Regulatory Support 
The following information was prepared in response to requirements of DOE Order 5400.2A.

DOE Operations Office: Richland

DOE Facility: Hanford Site

Existing Permit (X) Renewal ( ) New Permit ( )

Permit Type: State Waste Discharge Permit - WAC 173-216

Permitting Agency: Washington State Department of Ecology

Permit Number: ST 4500

Permitted Unit: 200 Area Effluent Treatment Facility

Issuance Date: June 26, 1995

Expiration Date: June 30, 2000

Need for Headquarters' Action

(for permit renewals or new permits)

Yes ( ) No (X)

If yes, HQ Program Element

Brief Summary of Relevant Information (major permit conditions, status of compliance or unusual problems):

Ecology Consent Order DE 91NM-177 lists regulatory milestones for liquid effluent streams at the Hanford Site to comply with the permitting requirements of WAC 173-216 (State Waste Discharge Program) or WAC 173-218 (Washington Underground Injection Control Program) where applicable. The State Waste Discharge Permit for the 200 Area Effluent Treatment Facility governs discharges of treated wastewater to the State Approved Land Disposal Site. The permit conditions include effluent limitations and monitoring requirements. A characterization study was submitted to Ecology on June 14, 1996, to allow treatment and disposal of groundwater from the 200-UP-1 Operable Unit on the Hanford Site. A public comment period is scheduled for August 5, 1996 through September 3, 1996, for modification to the permit allowing the groundwater as an inffluent source. Compliance has been maintained with the permit conditions except for elevated sulfate concentration in a groundwater monitoring well. The elevated sulfate is not the result of the 200 Area Effluent Treatment Facility operations, but is attributed to existing sulfate in the groundwater.

Prepared by: Westinghouse Hanford Company

Date: July 31,1996 Environmental Services 
The following information was prepared in response to requirements of DOE Order 5400.2A.

DOE Operations Office: Richland

DOE Facility: Hanford Site

Existing Permit ( X ) Renewal ( ) New Permit ( )

Permit Type: State Waste Discharge Permit - WAC 173-216

Permitting Agency: Washington State Department of Ecology

Permit Number: ST 4502

Permitted Unit: 200 Area Treated Effluent Disposal Facility, Project W-049H

Issuance Date: April 18, 1995

Expiration Date: April 18, 2000

Need for Headquarters' Action

(for permit renewals or new permits)

Yes ( ) No (X)

If yes, HQ Program Element

Brief Summary of Relevant Information (major permit conditions, status of compliance or unusual problems):

Ecology Consent Order DE $91 \mathrm{NM}-177$ lists regulatory milestones for liquid effluent streams at the Hanford Site to comply with the permitting requirements of WAC 173-216 (State Waste Discharge Program) or WAC 173-218 (Washington Underground Injection Control Program) where applicable. The permit provides the terms and conditions that regulate the discharge of treated waste water, via infiltration through soils, to the groundwaters of the state. The 200 Area Treated Effluent Disposal Facility (Project W-049) provides a collection, conveyance, and disposal system for treated effluents from seven buildings located in the 200 Areas. Project W- $049 \mathrm{H}$ completed Tri-Party Agreement milestones under M-17-00A and the Consent Order DE 91NM-177. Compliance with the permit conditions has been maintained except for an iron exceedance in April 1996. Additional wastewater streams are planned for discharge to the 200 Area Treated Effluent Disposal Facility in late 1996 and early 1997. Wastewater characterization information will be provided to Ecology for consideration. Ecology will determine if the permit will be modified to add the wastewater streams.

Prepared by: Westinghouse Hanford Company Environmental Services

Date: July 31, 1996 
The following information was prepared in response to requirements of DOE Order 5400.2A.

DOE Operations Office: Richland

DOE Facility: Hanford Site

Existing Permit ( ) Renewal ( ) New Permit (X)

Permit Type: State Waste Discharge Permit - WAC 173-216

Permitting Agency: Washington State Department of Ecology

Permit Number: ST $\mathbf{4 5 0 6}$

Permitted Unit: 200-E Chemical Drain Field

Issuance Date: TBD

Expiration Date: TBD

Need for Headquarters' Action

(for permit renewals or new permits)
Yes ( ) No (X)

If yes, identify appropriate HQ

Program Element

Brief Summary of Relevant Information (major permit conditions, status of compliance or unusual problems):

Ecology Consent Order DE 91NM-177 lists regulatory milestones for liquid effluent streams at the Hanford Site to comply with the permitting requirements of WAC 173-216 (State Waste Discharge Program) or WAC 173-218 (Washington Underground Injection Control Program) where applicable. As a result, a WAC 173-216 State Waste Discharge Permit application (document number DOE/RL-94-24, Rev. 0) has been submitted for the 272-E Building and 2703-E Building Waste Water streams. The 272-E floor drain and the north and south sumps in the 2703-E Building are the three contributors to the waste water stream discharging to the 200-E Chemical Drain Field. A Consent Order DE 91NM-177 milestone was satisfied with the submittal of the permit application to Ecology in June 1994. Ecology issued a public Notice of Application on May 29, 1995. A letter was issued to Ecology on December 20,1995, identifying that the contributing streams will be eliminated by February 1, 1996. On January 19, 1996, the 2703-E lines were permanently sealed, and on January 26, 1996, the 272-E drain pipe was plugged and permanently sealed. A letter was issued to Ecology on March 1, 1996, notifying Ecology of the completed actions, and requesting withdrawal of the permit application.

Prepared by: Westinghouse Hanford Company

Date: July 31, 1996 Environmental Services 
The following information was prepared in response to requirements of DOE Order 5400.2A.

DOE Operations Office: Richland

DOE Facility: Hanford Site

Existing Permit ( ) Renewal ( ) New Permit (X)

Permit Type: State Waste Discharge Permit - WAC 173-216

Permitting Agency: Washington State Department of Ecology

Permit Number: TBD

Permitted Unit: 200-E Powerhouse Ash Pit

Issuance Date: TBD

Expiration Date: TBD

Need for Headquarters' Action

(for permit renewals or new permits)

$$
\begin{aligned}
& \text { Yes ( ) No ( X) } \\
& \text { If yes, HQ Program Element }
\end{aligned}
$$

Brief Summary of Relevant Information (major permit conditions, status of compliance or unusual problems):

Ecology Consent Order DE 91NM-177 lists regulatory milestones for liquid effluent streams at the Hanford Site to comply with the permitting requirements of WAC 173-216 (State Waste Discharge Program) or WAC 173-218 (Washington Underground Injection Control Program) where applicable. As a result, a WAC 173-216 State Waste Discharge Permit application (DOE/RL-94-25, Rev. 0) was submitted for the 200-E Powerhouse Ash Pit waste water stream. The 200-E Powerhouse Ash Pit waste water results from sluicing the ash from the 284-E Powerhouse coal-fired boilers. The waste water is discharged to the $200-\mathrm{E}$ Powerhouse Ash Pit via dedicated pipelines. A Consent Order DE 91NM-177 milestone was satisfied with the submittal of the permit application to Ecology in June 1994. The permit application is currently under review by Ecology.

Prepared by: Westinghouse Hanford Company

Date: July 31, 1996 Environmental Services 
The following information was prepared in response to requirements of DOE Order 5400.2A.

DOE Operations Office: Richland

DOE Facility: Hanford Site

Existing Permit ( ) Renewal ( ) New Permit (X)

Permit Type: State Waste Discharge Permit - WAC 173-216

Permitting Agency: Washington State Department of Ecology

Permit Number: TBD

Permitted Unit: 200-W Powerhouse Ash Pit

Issuance Date: TBD

Expiration Date: TBD

Need for Headquarters' Action

(for permit renewals or new permits)
Yes ( ) No (X)

If yes, HQ Program Element

Brief Summary of Relevant Information (major permit conditions, status of compliance or unusual problems):

Ecology Consent Order DE 91NM-177 lists regulatory milestones for liquid effluent streams at the Hanford Site to comply with the permitting requirements of WAC 173-216 (State Waste Discharge Program) or WAC 173-218 (Washington Underground Injection Control Program) where applicable. As a result, a WAC 173-216 State Waste Discharge Permit application (DOE/RL-94-26, Rev. 0) has been submitted for the 200-W Powerhouse Ash Pit waste water stream. The 200-W Powerhouse Ash Pit waste water results from sluicing the ash from the 200-W Powerhouse coal-fired boilers. The waste water is discharged to the 200-W Powerhouse Ash Pit. A Consent Order DE 91NM-177 milestone was satisfied with the submittal of the permit application to Ecology in June 1994. The permit application is currently under review by Ecology.

Prepared by: Westinghouse Hanford Company

Date: July 31, 1996

Environmental Services 
The following information was prepared in response to requirements of DOE Order 5400.2A.

DOE Operations Office: Richland

DOE Facility: Hanford Site

Existing Permit ( ) Renewal ( ) New Permit (X)

Permit Type: State Waste Discharge Permit (Temporary) — WAC 173-216

Permitting Agency: Washington State Department of Ecology

Permit Number: TBD

Permitted Unit: 300 Area Ash Sluice Pond No. 2, Retrieval Technology Testing

Issuance Date: August 27, 1995

Expiration Date: October 31, 1996

Need for Headquarters' Action

Yes ( ) No (X)

(for permit renewals or new permits)

If yes, HQ Program Element

Brief Summary of Relevant Information (major permit conditions, status of compliance or unusual problems):

A State Waste Discharge Permit Application for One-Time/Limited Duration Discharges to ground was submitted in accordance with requirements of WAC 173-216. The activity permitted is for the Retrieval Technology Testing that will discharge test solutions from the 337 Building to the 300 Area Ash Sluice Pit No. 2. The test discharge will consist of two different solutions: kaolin and water ( 10 batches), and bentonite and water ( 9 batches). The estimated quantity of each batch test is 30 meters $^{3}\left(100\right.$ feet $\left.^{3}\right)$ of solids and 3,028 liters ( 800 gallons) of water. After testing begins, the batches of solution will be transported to the unlined ash pit approximately every 2 weeks. This will allow for sufficient time for the water to evaporate. Batch test approval is for the period of August 31, 1995, to approximately October 31, 1996. The solutions referred to are not regulated according to WAC 173-303 and would not exceed groundwater quality criteria established in WAC 173-200.

Prepared by: Pacific Northwest National Laboratory

Date: July 31, 1996 Environmental Compliance 
The following information was prepared in response to requirements of DOE Order 5400.2A.

DOE Operations Office: Richland

DOE Facility: Hanford Site

Existing Permit ( ) Renewal ( ) New Permit (X)

Permit Type: State Waste Discharge Permit - WAC 173-216

Permitting Agency: Washington State Department of Ecology

Permit Number: ST 4501

Permitted Unit: 400 Area Secondary Cooling Water

Issuance Date: July 31, 1996

Expiration Date: July 31, 2001

Need for Headquarters' Action

(for permit renewals or new permits)

\section{Yes ( ) No (X)}

If yes, HQ Program Element

Brief Summary of Relevant Information (major permit conditions, status of compliance or unusual problems):

Ecology Consent Order DE 91NM-177 lists regulatory milestones for liquid effluent streams at the Hanford Site to comply with the permitting requirements of WAC 173-216 (State Waste Discharge Program) or WAC 173-218 (Washington Underground Injection Control Program) where applicable. As a result, a WAC 173-216 State Waste Discharge Permit application (DOE/RL-94-89, Rev. 2) was submitted for the 400 Area Secondary Cooling Water stream. The 400 Area Secondary Cooling Water stream includes contributing streams for the Fuel Material Examination Facility, Maintenance and Storage Facility, 481-A Pump House, and Fast Flux Test Facility. The effluent is discharged to the 4608 Percolation Pond. A Consent Order DE 91NM-177 milestone was satisfied with the submittal of the permit application to Ecology in December 1992. The Permit was issued in July 1996. Additional wastewater characterization information will be submitted to Ecology for temporary discharges to the 400 Area Ponds in late 1996. Ecology will determine if the permit needs to be modified to allow the discharges.

Prepared by: Westinghouse Hanford Company

Date: July 31, 1996

Environmental Services 
The following information was prepared in response to requirements of DOE Order 5400.2A.

DOE Operations Office: Richland

DOE Facility: Hanford Site

Existing Permit ( ) Renewal ( ) New Permit (X)

Permit Type: State Waste Discharge Permit - WAC 173-216

Permitting Agency: Washington State Department of Ecology

Permit Number: ST 4505

Permitted Unit: 400 Area Septic System

Issuance Date: TBD

Expiration Date: TBD

Need for Headquarters' Action

(for permit renewals or new permits)
Yes ( ) No (X)

If yes, HQ Program Element

Brief Summary of Relevant Information (major permit conditions, status of compliance or unusual problems):

Ecology Consent Order DE 91NM-177 lists regulatory milestones for liquid effluent streams at the Hanford Site to comply with the permitting requirements of WAC 173-216 (State Waste Discharge Program) or WAC 173-218 (Washington Underground Injection Control Program) where applicable. As a result, a WAC 173-216 State Waste Discharge Permit application (DOE/RL-94-28, Rev. 0) was submitted for the 400 Area Stream. The 400 Area sanitary waste water is generated from standard sanitary processes and discharges to the 400 Area Septic System. A Consent Order DE $91 \mathrm{NM}-177$ milestone was satisfied with the submittal of the permit application to Ecology in June 1994. Ecology issued a public Notice of Application on May 29, 1995. The permit is on hold awaiting DOE-RL negotiations on an agreement with the Washington Public Power Supply System (WPPSS) for disposal of the sanitary waste in the WPPSS treatment system. A pipeline currently exists between the 400 Area and the WPPSS treatment systern; however, the pipeline has not been utilized.

Prepared by: · Westinghouse Hanford Company

Date: July 31, 1996 Environmental Services 
The following information was prepared in response to requirements of DOE Order 5400.2A.

DOE Operations Office: Richland

DOE Facility: Hanford Site

Existing Permit ( ) Renewal ( ) New Permit (X)

Permit Type: State Waste Discharge Permit - WAC 173-216

Permitting Agency: Washington State Department of Ecology

Permit Number:

Permitted Unit: Cooling Water and Condensate Discharges

Issuance Date: TBD

Expiration Date: TBD

Need for Headquarters' Action

(for permit renewals or new permits)
Yes ( ) No (X)

If yes, HQ Program Element

Brief Summary of Relevant Information (major permit conditions, status of compliance or unusual problems):

Ecology Consent Order DE 91NM-177 lists regulatory milestones for liquid effluent streams at the Hanford Site to comply with the permitting requirements of WAC 173-216 (State Waste Discharge Program) or WAC 173-218 (Washington Underground Injection Control Program) where applicable. The miscellaneous streams second categorical permit application for cooling water and condensate discharges was prepared for submittal to Ecology by September 30, 1996.

Prepared by: Westinghouse Hanford Company

Date: July 31,1996

\section{Environmental Services}


The following information was prepared in response to requirements of DOE Order 5400.2A.

DOE Operations Office: Richland

DOE Facility: Hanford Site

Existing Permit ( ) Renewal ( ) New Permit (X)

Permit Type: Categorical State Waste Discharge Permit - WAC 173-216

Permitting Agency: Washington State Department of Ecology

Permit Number: ST 4508

Permitted Unit: Hydrotesting, Construction, and Maintenance Discharges

Issuance Date: TBD

Expiration Date: TBD

Need for Headquarters' Action

(for permit renewals or new permits)

Yes ( ) No (X)

If yes, HQ Program Element

Brief Summary of Relevant Information (major permit conditions, status of compliance or unusual problems):

This permit application is for a Categorical State Waste Discharge Permit issued in accordance with requirements of WAC 173-216. The activity is to permit hydrotesting, maintenance, and construction discharges for the Hanford Site. The waste water from these activities is not discharged to engineered structures.

The permit application was developed to comply with the Plan and Schedule for Disposition and Regulatory Compliance for Miscellaneous Streams (DOE/RL-93-94, Rev. 1), commitment 6-2.3, and was submitted to Ecology on November 7, 1995. A Notice of Application was published in the local newspaper on May 13, 1996 and May 20, 1996. Ecology transmitted a draft permit for review on August 1,1996 . The Permit is scheduled to be issued in the fall of 1996 .

Prepared by: Westinghouse Hanford Company

Date: July 31, 1996

Environmental Services 
The following information was prepared in response to requirements of DOE Order 5400.2A.

DOE Operations Office: Richland

DOE Facility: Hanford Site

Existing Permit ( ) Renewal ( ) New Permit (X)

Permit Type: State Waste Discharge Permit - WAC 173-216

Permitting Agency: Washington State Department of Ecology

Permit Number: ST 4504

Permitted Unit: Other Phase II Liquid Effluent Streams

Issuance Date: TBD

Expiration Date: TBD

Need for Headquarters' Action (for permit renewals or new permits)

\section{Yes ( ) No (X)}

If yes, HQ Program Element

Brief Summary of Relevant Information (major permit conditions, status of compliance or unusual problems):

Consent Order DE 91NM-177 requires the submittal of a WAC 173-216 State Waste Discharge Permit Application for the "Other Phase II Liquid Effluent Streams" identified on Table 3 of Consent Order DE 91NM-177. A WAC 173-216 permit application (DOE/RL-93-61, Rev. 0) was prepared for the six "Other Phase II Streams" generated in the 200 East Area and disposed in B Pond. The six streams included are: 242-A Evaporator cooling water, 242-A Evaporator steam condensate, 241-A Tank Farm cooling water, 244-AR Vault cooling water, 284-E Power Plant waste water, and B Plant cooling water. A Consent Order DE $91 \mathrm{NM}-177$ milestone was satisfied with the submittal of the permit application to Ecology in December 1993. Through the permit modification process, these streams will now be diverted to the 200 Area Treated Effluent Disposal Facility. These waste streams will be permitted to allow discharge to the 200 Area Treated Effluent Disposal Facility by January 31, 1997.

Prepared by: Westinghouse Hanford Company

Date: July 31,1996 Environmental Services 
The following information was prepared in response to requirements of DOE Order 5400.2A.

DOE Operations Office: Richland

DOE Facility: Hanford Site

Existing Permit ( ) Renewal ( ) New Permit (X)

Permit Type: Underground Injection Control Program -. WAC 173-218

Permitting Agency: Washington State Department of Ecology

Permit Number: TBD

Permitted Unit: Class V Underground Injection Wells

Issuance Date: TBD

Expiration Date: TBD

Need for Headquarters' Action

(for permit renewals or new permits)
Yes ( ) No (X)

If yes, HQ Program Element

Brief Summary of Relevant Information (major permit conditions, status of compliance or unusual problems):

This permit application governs all new Class $V$ injection wells that inject industrial, municipal, or commercial waste fluids into or above an underground source of drinking water. Information for registration was submitted to Ecology on August 7, 1995, in accordance with commitments identified in the Plan and Schedule for Disposition and Regulatory Compliance for Miscellaneous Streams (DOE/RL-93-94).

Prepared by: Westinghouse Hanford Company

Date: July 31,1996 Environmental Services 
DOE/RL-96-63, Rev. 0

$10 / 96$

ONSITE SEWAGE SYSTEM PERMITTING 
DOE/RL-96-63, Rev. 0

$10 / 96$

This page intentionally left blank. 
The following information was prepared in response to requirements of DOE Order 5400.2A.

DOE Operations Office: Richland

DOE Facility: Hanford Site

Existing Permit ( ) Renewal (X) New Permit ( )

Permit Type: Onsite Sewage System - WAC 246-272

Permitting Agency: State of Washington Department of Health -- Spokane

Permit Number: N/A

Permitted Unit: 183-KE Septic Holding Tank

Issuance Date: August 31, 1993

Expiration Date: N/A

Need for Headquarters' Action

(for permit renewals or new permits)
Yes ( ) No (X)

If yes, HQ Program Element

Brief Summary of Relevant Information (major permit conditions, status of compliance or unusual problems):

Large onsite septic systems, septic systems with a design flow of greater than 13,249 liters (3,500 gallons) per day, are permitted annually in accordance with WAC 246-272-08001. The 183-KE Septic Tank (Project 183-KE serving mobile office MO-293 in the 100 Area) is a large permitted onsite septic system with a design capacity of 14,384 liters $(3,800$ gallons) per day.

Prepared by: Westinghouse Hanford Company

Date: July 31,1996

Environmental Services 
The following information was prepared in response to requirements of DOE Order 5400.2A.

DOE Operations Office: Richland

DOE Facility: Hanford Site

Existing Permit (X) Renewal ( ) New Permit ( )

Permit Type: Onsite Sewage System - WAC 246-272

Permitting Agency: State of Washington Department of Health - Spokane

Permit Number: N/A

Permitted Unit: 200 Area Effluent Treatment Facility Septic Holding Tanks

Issuance Date: September 1993

Expiration Date: TBD

Need for Headquarters' Action

(for permit renewals or new permits)
Yes ( ) No (X)

If yes, HQ Program Element

Brief Summary of Relevant Information (major permit conditions, status of compliance or unusual problems):

Holding tank sewage systems are permitted once in accordance with WAC 246-272-12501. Through negotiations with the Department of Health, the DOE-RL is allowed to install holding tank sewage systems on a temporary basis for up to 5 years. The 200 Area Effluent Treatment Facility holding tank sewage system is a permitted holding tank sewage system with a design capacity of 795 liters (210 gallons) per day.

Prepared by: Westinghouse Hanford Company

Date: July 31,1996 Environmental Services 
The following information was prepared in response to requirements of DOE Order 5400.2A.

DOE Operations Office: Richland

DOE Facility: Hanford Site

Existing Permit (X) Renewal ( ) New Permit ( )

Permit Type: Onsite Sewage System — WAC 246-272

Permitting Agency: State of Washington Department of Health - Spokane

Permit Number: N/A

Permitted Unit: 222-S Laboratory Complex, Septic Holding Tank

Issuance Date: November 16, 1994

Expiration Date: N/A

Need for Headquarters' Action

(for permit renewals or new permits)
Yes ( ) No ( $\mathrm{X}$ )

If yes, HQ Program Element

Brief Summary of Relevant Information (major permit conditions, status of compliance or unusual problems):

Holding tank sewage systems are permitted once in accordance with WAC 246-272-12501. Through negotiations with the Department of Health, the DOE-RL is allowed to install holding tank sewage systems on a temporary basis for up to 5 years. The 222-S Laboratory Complex (Project L-207) septic holding tank is a permitted holding tank sewage system with a design capacity of 4,542 liters (1,200 gallons) per day.

Prepared by: Westinghouse Hanford Company

Date: July 31, 1996

Environmental Services 
The following information was prepared in response to requirements of DOE Order 5400.2A.

DOE Operations Office: Richland

DOE Facility: Hanford Site

Existing Permit ( ) Renewal (X) New Permit ( )

Permit Type: Onsite Sewage System — WAC 246-272

Permitting Agency: State of Washington Department of Heaith - Spokane

Permit Number: HAN014

Permitted Unit: 1607-K4 Septic Tank

Issuance Date: September 11, 1995

Expiration Date: September 30, 1996

Need for Headquarters' Action

(for permit renewals or new permits)
Yes ( ) No (X)

If yes, HQ Program Element

Brief Summary of Relevant Information (major permit conditions, status of compliance or unusual problems):

Large onsite septic systems, septic systems with a design flow of greater than 13,249 liters (3,500 gallons) per day, are permitted annually in accordance with WAC 246-272-08001. The 1607-K4 Septic Tank (Project 1607-K4 serving mobile offices MO-401 and MO-402 in the $100-\mathrm{K}$ Area) is a large permitted onsite septic system with a design capacity of 14,384 liters (3,800 gallons) per day.

Prepared by: Westinghouse Hanford Company

Date: July 31,1996

\section{Environmental Services}


The following information was prepared in response to requirements of DOE Order 5400.2A.

DOE Operations Office: Richland

DOE Facility: Hanford Site

Existing Permit ( ) Renewal (X) New Permit ( )

Permit Type: Onsite Sewage System - WAC 246-272

Permitting Agency: State of Washington Department of Health - Spokane

Permit Number: HAN017

Permitted Unit: 2607-EP Septic Tank

Issuance Date: September 11, 1995

Expiration Date: September 30, 1996

Need for Headquarters' Action

(for permit renewals or new permits)

$$
\begin{aligned}
& \text { Yes ( ) No (X) } \\
& \text { If yes, HQ Program Element }
\end{aligned}
$$

Brief Summary of Relevant Information (major permit conditions, status of compliance or unusual problems):

Large onsite septic systems, septic systems with a design flow of greater than 13,249 liters (3,500 gallons) per day, are permitted annually in accordance with WAC 246-272-08001. The 2607-EP Septic Tank (Project L-132 serving building 2721-EA and adjacent facilities) is a large permitted onsite septic system with a design capacity of 54,888 liters (14,500 gallons) per day.

Prepared by: Westinghouse Hanford Company

Date: July 31, 1996 Environmental Services 
The following information was prepared in response to requirements of DOE Order $5400.2 \mathrm{~A}$.

DOE Operations Office: Richland

DOE Facility: Hanford Site

Existing Permit ( ) Renewal (X) New Permit ( )

Permit Type: Onsite Sewage System - WAC 246-272

Permitting Agency: State of Washington Department of Health - Spokane

Permit Number: HAN016

Permitted Unit: 2607-EQ Septic Tank

Issuance Date: September 11, 1995

Expiration Date: September 30, 1996

Need for Headquarters' Action Yes ( ) No (X)

(for permit renewals or new permits) If yes, HQ Program Element

Brief Summary of Relevant Information (major permit conditions, status of compliance or unusual problems):

Large onsite septic systems, septic systems with a design flow of greater than 13,249 liters (3,500 gallons) per day, are permitted annually in accordance with WAC 246-272-08001. The 2607-EQ Septic Tank (Project L092 serving buildings 2751-E, 2752-E, and 2753-E in the 200 East Area) is a large permitted onsite septic system with a design capacity of 54,131 liters (14,300 gallons) per day.

Prepared by: Westinghouse Hanford Company

Date: July 31, 1996

Environmental Services 
The following information was prepared in response to requirements of DOE Order $5400.2 \mathrm{~A}$.

DOE Operations Office: Richland

DOE Facility: Hanford Site

Existing Permit (X) Renewal ( ) New Permit ( )

Permit Type: Onsite Sewage System - WAC 246-272

Permitting Agency: State of Washington Department of Health - Spokane

Permit Number: N/A

Permitted Unit: 2607-E10 Septic Tank

Issuance Date: January 7, 1993

Expiration Date: N/A

Need for Headquarters' Action

(for permit renewals or new permits)
Yes ( ) No (X)

If yes, HQ Program Element

Brief Summary of Relevant Information (major permit conditions, status of compliance or unusual problems):

Onsite septic systems, septic systems with a design flow of less than 13,249 liters (3,500 gallons) per day, currently are permitted once in accordance with WAC 246-272-09001. The 2607-E10 Septic Tank (Project W-299, Grout Processing Support Facility) is a permitted onsite septic system with a design capacity of 4,164 liters (1,100 gallons) per day.

Prepared by: Westinghouse Hanford Company

Date: July 31,1996 Environmental Services 
The following information was prepared in response to requirements of DOE Order 5400.2A.

DOE Operations Office: Richland

DOE Facility: Hanford Site

Existing Permit ( ) Renewal (X) New Permit ( )

Permit Type: Onsite Sewage System - WAC 246-272

Permitting Agency: State of Washington Department of Health - Spokane

Permit Number: HAN012

Permitted Unit: 2607-E12 Septic Tank

Issuance Date: September 11, 1995

Expiration Date: September 30, 1996

Need for Headquarters' Action

(for permit renewals or new permits)
Yes ( ) No (X)

If yes, HQ Program Element

Brief Summary of Relevant Information (major permit conditions, status of compliance or unusual problems):

Large onsite septic systems, septic systems with a design flow of greater than 13,249 liters (3,500 gallons) per day, are permitted annually in accordance with WAC 246-272-08001. The 2607-E12 Septic Tank (Project W-172 serving buildings 272-AW, 242-A, and adjacent trailer units in the 200 East Area) is a large permitted onsite septic system with a design capacity of 25,400 liters (6,700 gallons) per day.

Prepared by: Westinghouse Hanford Company

Date: July 31, 1996

Environmental Services 
The following information was prepared in response to requirements of DOE Order 5400.2A.

DOE Operations Office: Richland

DOE Facility: Hanford Site

Existing Permit (X) Renewal ( ) New Permit ( )

Permit Type: Onsite Sewage System — WAC 246-272

Permitting Agency: State of Washington Department of Health - Spokane

Permit Number: N/A

Permitted Unit: 2607-WA East Septic Tank

Issuance Date: November 28, 1994

Expiration Date: N/A

Need for Headquarters' Action

(for permit renewals or new permits)

Yes ( ) No (X)

If yes, HQ Program Element

Brief Summary of Relevant Information (major permit conditions, status of compliance or unusual problems):

Onsite septic systems, septic systems with a design flow of less than 13,249 liters (3,500 gallons) per day, currently are permitted once in accordance with WAC 246-272-09001. The 2607-WA East Septic Tank (Project L-190 servicing the Information Resource Management Telecommunications Facility) is a permitted onsite septic system with a design capacity of 2,540 liters (670 gallons) per day.

Prepared by: Westinghouse Hanford Company

Date: July 31, 1996 Environmental Services 
The following information was prepared in response to requirements of DOE Order $5400.2 \mathrm{~A}$.

DOE Operations Office: Richland

DOE Facility: Hanford Site

Existing Permit ( ) Renewal (X) New Permit ( )

Permit Type: Onsite Sewage System - WAC 246-272

Permitting Agency: State of Washington Department of Health — Spokane

Permit Number: HAN009

Permitted Unit: 2607-W1 and 2607-W2 Septic Tanks

Issuance Date: September 11, 1995

Expiration Date: September 30, 1996

Need for Headquarters' Action

(for permit renewals or new permits)
Yes ( ) No ( $\mathrm{X}$ )

If yes, HQ Program Element

Brief Summary of Relevant Information (major permit conditions, status of compliance or unusual problems):

Large onsite septic systems, septic systems with a design flow of greater than 13,249 liters (3,500 gallons) per day, are permitted annually in accordance with WAC 246-272-08001. The 2607-W1 and 2607-W2 Septic Tanks (Project L-169 serving the following buildings in the 200 West Area: 272-W, 274-W, 275-W, 277-W, 284-W, 2704-W, 2707-W, 2709-W, 2713-W, 2720-W, 2723-W, 2724-W, and 2719-WA; and mobile office trailers MO-278, MO-279, MO-235, MO-406, MO-412, MO-215, MO-056, MO-204, and MO-240) is a large permitted onsite septic system with a design capacity of 54,900 liters (14,500 gallons) per day.

Prepared by: Westinghouse Hanford Company

Date: July 31,1996

Environmental Services 
The following information was prepared in response to requirements of DOE Order 5400.2A.

DOE Operations Office: Richland

DOE Facility: Hanford Site

Existing Permit (X) Renewal ( ) New Permit ( )

Permit Type: Onsite Sewage System - WAC 246-272

Permitting Agency: State of Washington Department of Health - Spokane

Permit Number: N/A

Permitted Unit: 2607-W11 and 2607-W12 Septic Tanks

Issuance Date: June 4, 1992

Expiration Date: TBD

Need for Headquarters' Action

(for permit renewals or new permits)
Yes ( ) No (X)

If yes, HQ Program Element

Brief Summary of Relevant Information (major permit conditions, status of compliance or unusual problems):

Onsite septic systems, septic systems with a design flow of less than 13,249 liters $(3,500$ gallons) per day, currently are permitted once in accordance with WAC 246-272-09001. The 2607-W11 and 2607-W12 Septic Tanks (Project W-219 serving the Modular Office and Changeroom Facilities) is a permitted onsite septic system with a design capacity of 4,921 liters (1,300 gallons) per day.

Prepared by: Westinghouse Hanford Company

Date: July 31,1996

Environmental Services 
The following information was prepared in response to requirements of DOE Order 5400.2A.

DOE Operations Office: Richland

DOE Facility: Hanford Site

Existing Permit (X) Renewal ( ) New Permit ( )

Permit Type: Onsite Sewage System — WAC 246-272

Permitting Agency: State of Washington Department of Health - Spokane

Permit Number: N/A

Permitted Unit: 2607-W14 Septic Tank

Issuance Date: April 6, 1995

Expiration Date: N/A

Need for Headquarters' Action

(for permit renewals or new permits)

$$
\begin{aligned}
& \text { Yes ( ) No (X) } \\
& \text { If yes, HQ Program Element }
\end{aligned}
$$

Brief Summary of Relevant Information (major permit conditions, status of compliance or unusual problems):

Onsite septic systems, septic systems with a design flow of less than 13,249 liters (3,500 gallons) per day, currently are permitted once in accordance with WAC 246-272-09001. The 2607-W14 Septic Tank (Project W-026 servicing the Waste Receiving and Processing Module 1) is a permitted onsite septic system with a design capacity of 9,577 liters (2,530 gallons) per day.

Prepared by: Westinghouse Hanford Company

Date: July 31,1996 Environmental Services 
The following information was prepared in response to requirements of DOE Order $5400.2 \mathrm{~A}$.

DOE Operations Office: Richland

DOE Facility: Hanford Site

Existing Permit ( ) Renewal ( ) New Permit (X)

Permit Type: Onsite Sewage System — WAC 246-272

Permitting Agency: State of Washington Department of Health - Spokane

Permit Number: N/A

Permitted Unit: 2607-W15 Septic Tank

Issuance Date: October 12, 1995

Expiration Date:

Need for Headquarters' Action

(for permit renewals or new permits)
Yes ( ) No (X)

If yes, HQ Program Element

Brief Summary of Relevant Information (major permit conditions, status of compliance or unusual problems):

Onsite septic systems, septic systems with a design flow of less than 13,249 liters (3,500 gallons) per day, currently are permitted once in accordance with WAC 246-272-09001. The 2607-W15 Septic Tank (Project W-112 serving buildings 2640-W and 2620-W in the 200 West Area) is a large permitted onsite septic system with a design capacity of 10,220 liters (2,700 gallons) per day.

Prepared by: Westinghouse Hanford Company

Date: July $31 ; 1996$

Environmental Services 
The following information was prepared in response to requirements of DOE Order $5400.2 \mathrm{~A}$.

DOE Operations Office: Richland

DOE Facility: Hanford Site

Existing Permit ( ) Renewal (X) New Permit ( )

Permit Type: Onsite Sewage System — WAC 246-272

Permitting Agency: State of Washington Department of Health - Spokane

Permit Number: HAN011

Permitted Unit: 6607-9 Septic Tank

Issuance Date: September 11, 1995

Expiration Date: September 30, 1996

Need for Headquarters' Action

(for permit renewals or new permits)

Yes ( ) No (X)

If yes, HQ Program Element

Brief Summary of Relevant Information (major permit conditions, status of compliance or unusual problems):

Large onsite septic systems, septic systems with a design flow of greater than 13,249 liters (3,500 gallons) per day, are permitted annually in accordance with WAC 246-272-08001. The 6607-9 Septic Tank (Project W-011H serving the Water Sampling and Characterization Facility and adjacent support buildings between the 200 East and 200 West Areas) is a permitted onsite septic system with a design capacity of 25,362 liters (6,700 gallons) per day.

Prepared by: Westinghouse Hanford Company

Date: July 31,1996

Environmental Services 
The following information was prepared in response to requirements of DOE Order 5400.2A.

DOE Operations Office: Richland

DOE Facility: Hanford Site

Existing Permit ( ) Renewal (X) New Permit ( )

Permit Type: Onsite Sewage System - WAC 246-272

Permitting Agency: State of Washington Department of Health -- Spokane

Permit Number: HAN003

Permitted Unit: 6607-11 Septic Tank

Issuance Date: September 11, 1995

Expiration Date: September 30, 1996

Need for Headquarters' Action

(for permit renewals or new permits)
Yes ( ) No ( $\mathrm{X}$ )

If yes, HQ Program Element

Brief Summary of Relevant Information (major permit conditions, status of compliance or unusual problems):

Large onsite septic systems, septic systems with a design flow of greater than 13,249 liters (3,500 gallons) per day, are permitted annually in accordance with WAC 246-272-08001. The 6607-11 Septic Tank (Project B-595 serving the Hanford Waste Vitrification Project Administration building and adjacent facilities) is a permitted onsite septic system with a design capacity of 44,668 liters (11,800 gallons) per day.

Prepared by: Westinghouse Hanford Company

Date: July 31,1996

Environmental Services 
The following information was prepared in response to requirements of DOE Order 5400.2A.

DOE Operations Office: Richland

DOE Facility: Hanford Site

Existing Permit ( ) Renewal (X) New Permit ( )

Permit Type: Onsite Sewage System - WAC 246-272

Permitting Agency: State of Washington Department of Health - Spokane

Permit Number: HAN005

Permitted Unit: 6607-16 Septic Tank

Issuance Date: September 11, 1995

Expiration Date: September 30, 1996

Need for Headquarters' Action

(for permit renewals or new permits)

$$
\begin{aligned}
& \text { Yes ( ) No (X) } \\
& \text { If yes, HQ Program Element }
\end{aligned}
$$

Brief Summary of Relevant Information (major permit conditions, status of compliance or unusual problems):

Large onsite septic systems, septic systems with a design flow of greater than 13,249 liters (3,500 gallons) per day, are permitted annually in accordance with WAC 246-272-08001. The 6607-16 Septic Tank (Project C-018 serving the 242-A Evaporator/PUREX Plant Condensate Treatment Facility) is a large permitted onsite septic system with a design capacity of 18,927 liters (5,000 gallons) per day.

Prepared by: Westinghouse Hanford Company

Date: July 31, 1996 Environmental Services 
The following information was prepared in response to requirements of DOE Order 5400.2A.

DOE Operations Office: Richland

DOE Facility: Hanford Site

Existing Permit ( ) Renewal ( ) New Permit (X)

Permit Type: Onsite Sewage System - WAC 246-272

Permitting Agency: State of Washington Department of Health — Spokane

Permit Number: N/A

Permitted Unit: 6607-17 Septic Tank

Issuance Date: TBD

Expiration Date: N/A

Need for Headquarters' Action (for permit renewals or new permits)
Yes ( ) No (X)

If yes, HQ Program Element

Brief Summary of Relevant Information (major permit conditions, status of compliance or unusual problems):

Onsite septic systems, septic systems with a design flow of less than 13,249 liters (3,500 gallons) per day, currently are permitted once in accordance with WAC 246-272-09001. The 6607-17 Septic Tank (Project L-044 servicing the Hanford Infrastructure Underground Storage Tanks) is a permitted onsite septic system with a design capacity of 1,365 liters ( 360 gallons) per day.

Prepared by: Westinghouse Hanford Company

Date: July 31, 1996

Environmental Services 
The following information was prepared in response to requirements of DOE Order 5400.2A.

DOE Operations Office: Richland

DOE Facility: Hanford Site

Existing Permit ( ) Renewal ( ) New Permit (X)

Permit Type: Onsite Sewage System — WAC 246-272

Permitting Agency: State of Washington Department of Health -- Spokane

Permit Number: N/A

Permitted Unit: Environmental Molecular Sciences Laboratory Temporary Septic Hoiding Tank Issuance Date: TBD

Expiration Date: N/A

Need for Headquarters' Action

(for permit renewals or new permits)

\section{Yes ( ) No (X)}

If yes, HQ Program Element

Brief Summary of Relevant Information (major permit conditions, status of compliance or unusual problems):

The Environmental Molecular Sciences Laboratory Temporary Septic Holding Tank (Project D-384 servicing the construction trailers) will install a temporary sanitary waste water holding tank. The septic holding tank will be used until a new pipeline to the city of Richland sanitary waste water system is installed.

Prepared by: Pacific Northwest National Laboratory

Date: July 31,1996 Environmental Compliance 
DOE/RL-96-63, Rev. 0

$10 / 96$

\section{PETROLEUM UNDERGROUND STORAGE TANK PERMITTING}


DOE/RL-96-63, Rev. 0

$10 / 96$

This page intentionally left blank. 
The following information was prepared in response to requirements of DOE Order 5400.2A.

DOE Operations Office: Richland

DOE Facility: Hanford Site

Existing Permit ( ) Renewal (X) New Permit ( )

Permit Type: Annual Permit for Active Petroleum Underground Storage Tanks WAC 173-360

Permitting Agency: Washington State Department of Ecology

Permit Number: 181B-66

Permitted Unit: 100B Area, Tank 181B-66

Issuance Date: June 30, 1996

Expiration Date: June 30, 1997 .

Need for Headquarters' Action

(for permit renewals or new permits)
Yes ( ) No (X)

If yes, HQ Program Element

Brief Summary of Relevant Information (major permit conditions, status of compliance or unusual problems):

Annual permits and information updates are required each year for each active petroleum underground storage tank on the Hanford Site. The petroleum underground storage tanks store used oil, supply gasoline fuel for site vehicles, and supply diesel fuel for site vehicles and emergency generator systems. Tank 181B-66 contains diesel fuel. A tank permit was renewed and Ecology issued Master Business License 601310923 on June 30, 1996. This tank permit has been placed on hold for the $181 \mathrm{~B}-66$ tank.

Prepared by: Westinghouse Hanford Company

Date: July 31,1996

Environmental Services 
The following information was prepared in response to requirements of DOE Order 5400.2A.

DOE Operations Office: Richland

DOE Facility: Hanford Site

Existing Permit ( ) Renewal (X) New Permit ( )

Permit Type: Annual Permit for Active Petroleum Underground Storage Tanks WAC $173-360$

Permitting Agency: Washington State Department of Ecology

Permit Number: 204-AR

Permitted Unit: 200 East Area, Tank 204-AR

Issuance Date: June 30, 1996

Expiration Date: June 30, 1997

Need for Headquarters' Action (for permit renewals or new permits)
Yes ( ) No (X)

If yes, HQ Program Element

Brief Summary of Relevant Information (major permit conditions, status of compliance or unusual problems):

Annual permits and information updates are required each year for each active petroleum underground storage tank on the Hanford Site. The petroleum underground storage tanks store used oil, supply gasoline fuel for site vehicles, and supply diesel fuel for site vehicles and emergency generator systems. Tank 204-AR contains diesel fuel. The tank permit was renewed and Ecology issued Master Business License 601310923 on June 30, 1996.

Prepared by: Westinghouse Hanford Company

Date: July 31, 1996

Environmental Services 
The following information was prepared in response to requirements of DOE Order 5400.2A.

DOE Operations Office: Richland

DOE Facility: Hanford Site

Existing Permit ( ) Renewal (X) New Permit ( )

Permit Type: Annual Permit for Active Petroleum Underground Storage Tanks WAC $173-360$

Permitting Agency: Washington State Department of Ecology

Permit Number: 241-A-701

Permitted Unit: 200 East Area, Tank 241-A-701

Issuance Date: June 30, 1996

Expiration Date: June 30, 1997

Need for Headquarters' Action

Yes ( ) No (X)

(for permit renewals or new permits) If yes, HQ Program Element

Brief Summary of Relevant Information (major permit conditions, status of compliance or unusual problems):

Annual permits and information updates are required each year for each active petroleum underground storage tank on the Hanford Site. The petroleum underground storage tanks store used oil, supply gasoline fuel for site vehicles, and supply diesel fuel for site vehicles and emergency generator systems. Tank 241-A-701 contains diesel fuel. The tank permit was renewed and Ecology issued Master Business License 601310923 on June 30, 1996.

Prepared by: Westinghouse Hanford Company

Date: July 31,1996

Environmental Services 
The following information was prepared in response to requirements of DOE Order 5400.2A.

DOE Operations Office: Richland

DOE Facility: Hanford Site

Existing Permit ( ) Renewal (X) New Permit ( )

Permit Type: Annual Permit for Active Petroleum Underground Storage Tanks WAC 173-360

Permitting Agency: Washington State Department of Ecology

Permit Number: 241-A-701-2

Permitted Unit: 200 East Area, Tank 241-A-701-2

Issuance Date: June 30, 1996

Expiration Date: June 30, 1997

Need for Headquarters' Action

(for permit renewals or new permits)

Yes ( ) No (X)

If yes, HQ Program Element

Brief Summary of Relevant Information (major permit conditions, status of compliance or unusual problems):

Annual permits and information updates are required each year for each active petroleum underground storage tank on the Hanford Site. The petroleum underground storage tanks store used oil, supply gasoline fuel for site vehicles, and supply diesel fuel for site vehicles and emergency generator systems. Tank 241-A-701-2 contains diesel fuel. The tank permit was renewed and Ecology issued Master Business License 601310923 on June 30, 1996.

Prepared by: Westinghouse Hanford Company

Date: July 31,1996

Environmental Services 
The following information was prepared in response to requirements of DOE Order $5400.2 \mathrm{~A}$.

DOE Operations Office: Richland

DOE Facility: Hanford Site

Existing Permit ( ) Renewal (X) New Permit ( )

Permit Type: Annual Permit for Active Petroleum Underground Storage Tanks WAC $173-360$

Permitting Agency: Washington State Department of Ecology

Permit Number: $242-\mathrm{A}-1$

Permitted Unit: 200 East Area, Tank 242-A-1

Issuance Date: June 30, 1996

Expiration Date: June 30, 1997

Need for Headquarters' Action

(for permit renewals or new permits)

Yes ( ) No $(X)$

If yes, HQ Program Element

Brief Summary of Relevant Information (major permit conditions, status of compliance or unusual problems):

Annual permits and information updates are required each year for each active petroleum underground storage tank on the Hanford Site. The petroleum underground storage tanks store used oil, supply gasoline fuel for site vehicles, and supply diesel fuel for site vehicles and emergency generator systems. Tank 242-A-1 contains diesel fuel. The tank permit was renewed and Ecology issued Master Business License 601310923 on June 30, 1996.

Prepared by: Westinghouse Hanford Company

Date: July 31, 1996 Environmental Services 
The following information was prepared in response to requirements of DOE Order 5400.2A.

DOE Operations Office: Richland

DOE Facility: Hanford Site

Existing Permit ( ) Renewal (X) New Permit ( )

Permit Type: Annual Permit for Active Petroleum Underground Storage Tanks WAC 173-360

Permitting Agency: Washington State Department of Ecology

Permit Number: 244-AR

Permitted Unit: 200 East Area, Tank 244-AR

Issuance Date: June 30, 1996

Expiration Date: June 30, 1997

Need for Headquarters' Action

Yes ( ) No (X)

(for permit renewals or new permits)

If yes, HQ Program Element

Brief Summary of Relevant Information (major permit conditions, status of compliance or unusual problems):

Annual permits and information updates are required each year for each active petroleum underground storage tank on the Hanford Site. The petroleum underground storage tanks store used oil, supply gasoline fuel for site vehicles, and supply diesel fuel for site vehicles and emergency generator systems. Tank 244-AR contains diesel fuel. The tank permit was renewed and Ecology issued Master Business License 601310923 June 30, 1996.

Prepared by: Westinghouse Hanford Company

Date: July 31,1996

Environmental Services 
The following information was prepared in response to requirements of DOE Order 5400.2A.

DOE Operations Office: Richland

DOE Facility: Hanford Site

Existing Permit ( ) Renewal (X) New Permit ( )

Permit Type: Annual Permit for Active Petroleum Underground Storage Tanks WAC 173-360

Permitting Agency: Washington State Department of Ecology

Permit Number: 281-A-1

Permitted Unit: 200 East Area, Tank 281-A-1

Issuance Date: June 30, 1996

Expiration Date: June 30, 1997

Need for Headquarters' Action

(for permit renewals or new permits)

\section{Yes ( ) No (X)}

If yes, HQ Program Element

Brief Summary of Relevant Information (major permit conditions, status of compliance or unusual problems):

Annual permits and information updates are required each year for each active petroleum underground storage tank on the Hanford Site. The petroleum underground storage tanks store used oil, supply gasoline fuel for site vehicles, and supply diesel fuel for site vehicles and emergency generator systems. Tank 281-A-1 contains diesel fuel. The tank permit was renewed and Ecology issued Master Business License 601310923 on June 30, 1996. This tank permit has been placed on hold for the 281-A-1 tank.

Prepared by: Westinghouse Hanford Company

Date: July 31,1996 Environmental Services 
The following information was prepared in response to requirements of DOE Order 5400.2A.

DOE Operations Office: Richland

DOE Facility: Hanford Site

Existing Permit ( ) Renewal (X) New Permit ( )

Permit Type: Annual Permit for Active Petroleum Underground Storage Tanks -WAC 173-360

Permitting Agency: Washington State Department of Ecology

Permit Number: 2711E-66

Permitted Unit: 200 East Area, Tank 2711-66

Issuance Date: June 30, 1996

Expiration Date: June 30, 1997

Need for Headquarters' Action

(for permit renewals or new permits)

Yes ( ) No (X)

If yes, HQ Program Element

Brief Summary of Relevant Information (major permit conditions, status of compliance or unusual problems):

Annual permits and information updates are required each year for each active petroleum underground storage tank on the Hanford Site. The petroleum underground storage tanks store used oil, supply gasoline fuel for site vehicles, and supply diesel fuel for site vehicles and emergency generator systems. Tank 2711-66 contains used oil. The tank permit was renewed and Ecology issued Master Business License 601310923 on June 30, 1996.

Prepared by: Westinghouse Hanford Company

Date: July 31, 1996

Environmental Services 
The following information was prepared in response to requirements of DOE Order 5400.2A.

DOE Operations Office: Richland

DOE Facility: Hanford Site

Existing Permit ( ) Renewal (X) New Permit ( )

Permit Type: Annual Permit for Active Petroleum Underground Storage Tanks WAC 173-360

Permitting Agency: Washington State Department of Ecology

Permit Number: 2711E-66

Permitted Unit: 200 East Area, Tank 2711-66A

Issuance Date: June 30, 1996

Expiration Date: June 30, 1997

Need for Headquarters' Action

(for permit renewals or new permits)

\section{Yes ( ) No (X)}

If yes, HQ Program Element

Brief Summary of Relevant Information (major permit conditions, status of compliance or unusual problems):

Annual permits and information updates are required each year for each active petroleum underground storage tank on the Hanford Site. The petroleum underground storage tanks store used oil, supply gasoline fuel for site vehicles, and supply diesel fuel for site vehicles and emergency generator systems. Tank 2711-66A contains used oil. The tank permit was renewed and Ecology issued Master Business License 601310923 on June 30, 1996.

Prepared by: Westinghouse Hanford Company

Date: July 31,1996 Environmental Services 
The following information was prepared in response to requirements of DOE Order 5400.2A.

DOE Operations Office: Richland

DOE Facility: Hanford Site

Existing Permit ( ) Renewal (X) New Permit ( )

Permit Type: Annual Permit for Active Petroleum Underground Storage Tanks WAC 173-360

Permitting Agency: Washington State Department of Ecology

Permit Number: $2721 Z-1$

Permitted Unit: 200 West Area, Tank 2721Z-1

Issuance Date: June 30, 1996

Expiration Date: June 30, 1997

Need for Headquarters' Action

(for permit renewals or new permits)
Yes ( ) No (X)

- If yes, HQ Program Element

Brief Summary of Relevant Information (major permit conditions, status of compliance or unusual problems):

Annual permits and information updates are required each year for each active petroleum underground storage tank on the Hanford Site. The petroleum underground storage tanks store used oil, supply gasoline fuel for site vehicles, and supply diesel fuel for site vehicles and emergency generator systems. Tank 2721Z-1 contains diesel fuel. The tank permit was renewed and Ecology issued Master Business License 601310923 on June 30, 1996.

Prepared by: Westinghouse Hanford Company

Date: July 31, 1996

Environmental Services 
The following information was prepared in response to requirements of DOE Order 5400.2A.

DOE Operations Office: Richland

DOE Facility: Hanford Site

Existing Permit ( ) Renewal (X) New Permit ( )

Permit Type: Annual Permit for Active Petroleum Underground Storage Tanks WAC 173-360

Permitting Agency: Washington State Department of Ecology

Permit Number: 2736 ZA-1

Permitted Unit: 200 West Area, Tank 2736ZA-1

Issuance Date: June 30, 1996

Expiration Date: June 30, 1997

Need for Headquarters' Action

(for permit renewals or new permits)
Yes ( ) No (X)

If yes, HQ Program Element

Brief Summary of Relevant Information (major permit conditions, status of compliance or unusual problems):

Annual permits and information updates are required each year for each active petroleum underground storage tank on the Hanford Site. The petroleum underground storage tanks store used oil, supply gasoline fuel for site vehicles, and supply diesel fuel for site vehicles and emergency generator systems. Tank 2736ZA-1 contains diesel fuel. The tank permit was renewed and Ecology issued Master Business License 601310923 on June 30, 1996.

Prepared by: Westinghouse Hanford Company

Date: July 31, 1996 Environmental Services 
The following information was prepared in response to requirements of DOE Order $5400.2 \mathrm{~A}$.

DOE Operations Office: Richland

DOE Facility: Hanford Site

Existing Permit ( ) Renewal (X) New Permit ( )

Permit Type: Annual Permit for Active Petroleum Underground Storage Tanks WAC 173-360

Permitting Agency: Washington State Department of Ecology

Permit Number: 3621-C

Permitted Unit: 300 Area, Tank 3621-C

Issuance Date: June 30, 1996

Expiration Date: June 30, 1997

Need for Headquarters' Action

(for permit renewals or new permits)
Yes ( ) No (X)

If yes, HQ Program Element

Brief Summary of Relevant Information (major permit conditions, status of compliance or unusual problems):

Annual permits and information updates are required each year for each active petroleum underground storage tank on the Hanford Site. The petroleum underground storage tanks store used oil, supply gasoline fuel for site vehicles, and supply diesel fuel for site vehicles and emergency generator systems. Tank 3621-C contains diesel fuel. The tank permit was renewed and Ecology issued Master Business License 601310923 on June 30, 1996.

Prepared by: Westinghouse Hanford Company

Date: July 31, 1996

Environmental Services 
The following information was prepared in response to requirements of DOE Order 5400.2A.

DOE Operations Office: Richland

DOE Facility: Hanford Site

Existing Permit ( ) Renewal ( ) New Permit (X)

Permit Type: Annual Permit for Active Petroleum Underground Storage Tanks WAC $173-360$

Permitting Agency: Washington State Department of Ecology

Permit Number: $3621-66$

Permitted Unit: 300 Area, Tank 3621-66

Issuance Date: June 30, 1996

Expiration Date: June 30, 1997

Need for Headquarters' Action

(for permit renewals or new permits)

Yes ( ) No (X)

If yes, HQ Program Element

Brief Summary of Relevant Information (major permit conditions, status of compliance or unusual problems):

Annual permits and information updates are required each year for each active petroleum underground storage tank on the Hanford Site. The petroleum underground storage tanks store used oil, supply gasoline fuel for site vehicles, and supply diesel fuel for site vehicles and emergency generator systems. Tank 3621-66 contains diesel fuel. A new underground storage tank permit was submitted and Ecology issued Master Business License 601310923 on June 30, 1996.

Prepared by: Westinghouse Hanford Company

Date: July 31,1996 Environmental Services 
The following information was prepared in response to requirements of DOE Order 5400.2A.

DOE Operations Office: Richland

DOE Facility: Hanford Site

Existing Permit ( ) Renewal (X) New Permit ( )

Permit Type: Annual Permit for Active Petroleum Underground Storage Tanks WAC 173-360

Permitting Agency: Washington State Department of Ecology

Permit Number: 400-FFTF-T303

Permitted Unit: 400 Area, Tank 400-FFTF-T303

Issuance Date: June 30, 1996

Expiration Date: June 30, 1997

Need for Headquarters' Action

(for permit renewals or new permits)

\section{Yes ( ) No (X)}

If yes, HQ Program Element

Brief Summary of Relevant Information (major permit conditions, status of compliance or unusual problems):

Annual permits and information updates are required each year for each active petroleum underground storage tank on the Hanford Site. The petroleum underground storage tanks store used oil, supply gasoline fuel for site vehicles, and supply diesel fuel for site vehicles and emergency generator systems. Tank 400-FFTF-T303 contains diesel fuel. The tank permit was renewed and Ecology issued Master Business License 601310923 on June 30, 1996.

Prepared by: Westinghouse Hanford Company

Date: July 31, 1996

Environmental Services 
The following information was prepared in response to requirements of DOE Order $5400.2 \mathrm{~A}$.

DOE Operations Office: Richland

DOE Facility: Hanford Site

Existing Permit ( ) Renewal ( ) New Permit (X)

Permit Type: Annual Permit for Active Petroleum Underground Storage Tanks WAC 173-360

Permitting Agency: Washington State Department of Ecology

Permit Number: 6291-66

Permitted Unit: 600 Area, Tank 6291-66

Issuance Date: June 30, 1996

Expiration Date: June 30, 1997

Need for Headquarters' Action

(for permit renewals or new permits)

$$
\begin{aligned}
& \text { Yes ( ) No (X) } \\
& \text { If yes, HQ Program Element }
\end{aligned}
$$

Brief Summary of Relevant Information (major permit conditions, status of compliance or unusual problems):

Annual permits and information updates are required each year for each active petroleum underground storage tank on the Hanford Site. The petroleum underground storage tanks store used oil, supply gasoline fuel for site vehicles, and supply diesel fuel for site vehicles and emergency generator systems. Tank 6291-66 contains diesel fuel. A new underground storage tank permit was submitted and Ecology issued Master Business License 601310923 on June 30, 1996.

Prepared by: Westinghouse Hanford Company

Date: July 31,1996 Environmental Services 
The following information was prepared in response to requirements of DOE Order $5400.2 \mathrm{~A}$.

DOE Operations Office: Richland

DOE Facility: Hanford Site

Existing Permit ( ) $\quad$ Renewal ( ) New Permit (X)

Permit Type: Annual Permit for Active Petroleum Underground Storage Tanks WAC 173-360

Permitting Agency: Washington State Department of Ecology

Permit Number: 6291-66A

Permitted Unit: 600 Area, Tank 6291-66A

Issuance Date: June 30, 1996

Expiration Date: June 30, 1997

Need for Headquarters' Action

(for permit renewals or new permits)
Yes ( ) No (X)

If yes, HQ Program Element

Brief Summary of Relevant Information (major permit conditions, status of compliance or unusual problems):

Annual permits and information updates are required each year for each active petroleum underground storage tank on the Hanford Site. The petroleum underground storage tanks store used oil, supply gasoline fuel for site vehicles, and supply diesel fuel for site vehicles and emergency generator systems. Tank 6291-66A contains diesel fuel. A new underground storage tank permit was submitted and Ecology issued Master Business License 601310923 on June 30, 1996.

Prepared by: Westinghouse Hanford Company

Date: July 31, 1996

Environmental Services 
The following information was prepared in response to requirements of DOE Order 5400.2A.

DOE Operations Office: Richland

DOE Facility: Hanford Site

Existing Permit ( ) Renewal ( ) New Permit (X)

Permit Type: Annual Permit for Active Petroleum Underground Storage Tanks -... WAC $173-360$

Permitting Agency: Washington State Department of Ecology

Permit Number: $1172-66$

Permitted Unit: 1100 Area, Tank 1172-66

Issuance Date: June 30, 1996

Expiration Date: June 30, 1997

Need for Headquarters' Action

(for permit renewals or new permits)
Yes ( ) No ( $X)$

If yes, HQ Program Element

Brief Summary of Relevant Information (major permit conditions, status of compliance or unusual problems):

Annual permits and information updates are required each year for each active petroleum underground storage tank on the Hanford Site. The petroleum underground storage tanks store used oil, supply gasoline fuel for site vehicles, and supply diesel fuel for site vehicles and emergency generator systems. Tank 1172-66 contains diesel fuel. A new underground storage tank permit was submitted and Ecology issued Master Business License 601310923 on June 30, 1996.

Prepared by: Westinghouse Hanford Company

Date: July 31, 1996 Environmental Services 
The following information was prepared in response to requirements of DOE Order $5400.2 \mathrm{~A}$.

DOE Operations Office: Richland

DOE Facility: Hanford Site

Existing Permit ( ) Renewal ( ) New Permit (X)

Permit Type: Annual Permit for Active Petroleum Underground Storage Tanks WAC 173-360

Permitting Agency: Washington State Department of Ecology

Permit Number: $1172-66 \mathrm{~A}$

Permitted Unit: 1100 Area, Tank 1172-66A

Issuance Date: June 30, 1996

Expiration Date: June 30, 1997

Need for Headquarters' Action

(for permit renewals or new permits)
Yes ( ) No (X)

If yes, HQ Program Element

Brief Summary of Relevant Information (major permit conditions, status of compliance or unusual problems):

Annual permits and information updates are required each year for each active petroleum underground storage tank on the Hanford Site. The petroleum underground storage tanks store used oil, supply gasoline fuel for site vehicles, and supply diesel fuel for site vehicles and emergency generator systems. Tank 1172-66A contains diesel fuel. A new underground storage tank permit was submitted and Ecology issued Master Business License 601310923 on June 30, 1996.

Prepared by: Westinghouse Hanford Company

Date: July 31, 1996 Environmental Services 


\section{REFERENCES}

15 USC 2601 et seq., Toxic Substances Control Act of 1976

33 USC 1251, Clean Water Act Amendment of 1987

42 USC 7401, Clean Air Act Amendment of 1990

DOE, 1994, Plan and Schedule for Disposition and Regulatory Compliance for Miscellaneous Streams, DOE/RL-93-94, Rev. 1, U.S. Department of Energy, Richland Operations Office, Richland, Washington.

Ecology, 1996, Dangerous Waste Part B Permit Application Requirements, Publication No. 95-402, Washington State Department of Ecology, Olympia, Washington.

Ecology, EPA, and DOE, 1995, Hanford Federal Facility Agreement and Consent Order, Washington State Department of Ecology, U.S. Environmental Protection Agency, and U.S. Department of Energy, Olympia, Washington.

Ecology and U.S. DOE, 1991, Consent Order No. DE91N-177, Washington Department of Ecology, and U.S. Department of Energy, Olympia, Washington.

EPA, 1989, National Emission Standards for Hazardous Air Pollutants, Title 40 Code of Federal Regulations, Part 61, Subpart H, U.S. Environmental Protection Agency, Washington, D.C.

WAC 173-200, Water Quality Standards for Ground Waters of the State of Washington, Washington State Department of Ecology, Olympia, Washington.

WAC 173-216, State Waste Discharge Permit Program, Washington State Department of Ecology, Olympia, Washington.

WAC 173-218, Underground Injection Control Program, Washington State Department of Ecology, Olympia, Washington.

WAC 173-240, Submission of Plans and Reports for Construction of Wastewater Facilities, Washington State Department of Ecology, Olympia, Washington.

WAC 173-303, Dangerous Waste Regulations, Washington State Department of Ecology, Olympia, Washington.

WAC 173-400, General Regulations for Air Pollution Sources, Washington State Department of Ecology, Olympia, Washington. 
WAC 173-401, Operating Permit Regulation, Washington State Department of Ecology, Olympia, Washington.

WAC 173-460, Controls for New Sources of Toxic Air Pollutants, Washington State Department of Ecology, Olympia, Washington.

WAC 246-247, Rules and Regulations for Radiation Protection-Air Emissions Edition, Washington State Department of Health, Spokane, Washington. 
WAC 173-401, Operating Permit Regulation, Washington State Department of Ecology, Olympia, Washington.

WAC 173-460, Controls for New Sources of Toxic Air Pollutants, Washington State Department of Ecology, Olympia, Washington.

WAC 246-247, Rules and Regulations for Radiation Protection-Air Emissions Edition, Washington State Department of Health, Spokane, Washington. 
Number of

Copies

Onsite

6

U.S. Department of Energy. Richland Operations Office

C. E. Clark

A5-15

R. N. Krekel

A5-15

E. M. Mattlin

A5-15

A. C. McKarns

A5-15

H. M. Rodriguez

A $5-15$

Public Reading Room

$\mathrm{H} 2-53$

2

Bechtel Hanford. Inc.

R. J. Landon

$\mathrm{H} 0-18$

P. J. Mackey

H0-09

1 ICF Kaiser Hanford

B. J. Dixon

B4-20

2 Pacific Northwest National Laboratory

B. A. Flores

P7-79

H. T. Tilden III

P7-79

19 Westinghouse Hanford Company

D. Alison

R1 -51

N. A. Ballantyne

S6-71

R. C. Bowman

H6-24

B. G. Erlandson

R2-36

L. A. Garner

R2-36

K. A. Hadley

R3-56

J. J. Luke

H6-25

R. D. Pierce

T3-04

S. M. Price

H6-23

S. A. Thompson

H6-22

B. D. Williamson

B3-15 
Westinghouse Hanfnord Company (continued)

Administrative Record

H6-08

Central Files

Document Processing Center

Facility Operating Record

Information Release Administration

RCRA Files (J. McCoy)

Unclassified Document Control
A3-88

A3-94

H6-08

R1-08

H6-23

A3-95

Offsite

Number of

Copies

1

Joe Witczak

Washington State Department fo Ecology

P.O. Box 47600

Olympia, WA 98504-7600

1

Greta Davis

B5-18

Washington State Department of Ecology

2

Moses Jaraysi

B5-18

Washington State Department of Ecology

1

Steve Skurla

B5-18

Washington State Department of Ecology

1

J. R. Wilkinson

Department of Natural Resources

Confederated Tribes of the Umatilla Indian Reservation

P.O. Box 638

Pendleton, OR 97801

1 Russell Jim, Manager

Restoriation /Waste management

Confederated Tribes and Bands of the Yakama Nation

P.O. Box 151

Toppenish, WA 98948

1 Donna Powaukee

Nez Perce Tribe

P.O. Box 305

Lapwai, ID 80540

Distr-2 
Environmental Protection Agency

Anita Frankel

U.S. Environmental Protection Agency, Region 10 1200 Sixth Avenue, Msin Hw-106

Seattle, Washington 98101

Al W. Conklin, Head

Air Emissions and Defense

Waste Section

Division of Radiation Protection

State of Washington Department of Health

P.O. Box 47827

Olympia, Washington 98504-7827 